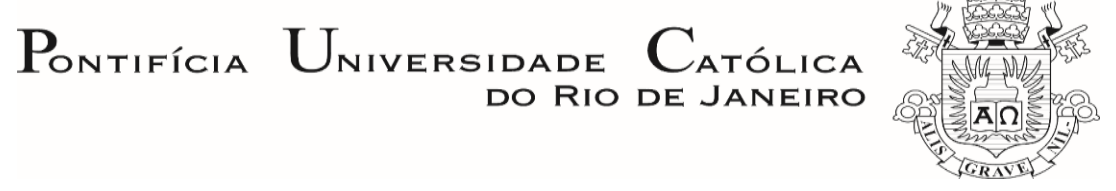

Wanderson Antonio Vicente Jardim

\begin{abstract}
A POLÍTICA NACIONAL DE RESÍDUOS SÓLIDOS, SEUS AVANÇOS E RETROCESSOS: uma análise a partir de sua implantação no município do Arraial do Cabo
\end{abstract}

Tese de Doutorado

Tese apresentada ao Programa de Pós-Graduação em Serviço Social da PUC-Rio como requisito parcial para obtenção do grau de Doutor em Serviço Social

Orientadora: Profa. Valéria Pereira Bastos

Rio de Janeiro

Dezembro de 2018 


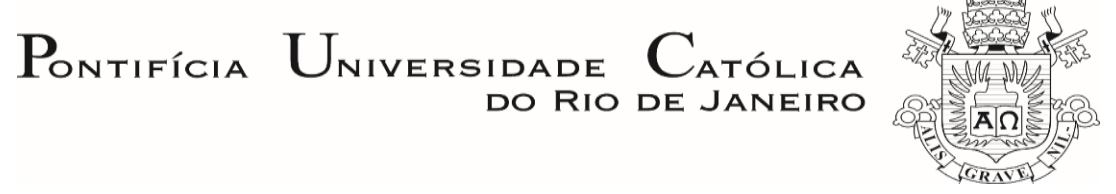

Wanderson Antonio Vicente Jardim

\title{
A POLÍTICA NACIONAL DE RESÍDUOS SÓLIDOS, SEUS AVANÇOS E RETROCESSOS: uma análise a partir de sua implantação no município do Arraial do Cabo
}

\begin{abstract}
Tese apresentada como requisito parcial para obtenção do grau de doutor pelo Programa de Pós-Graduação em Serviço Social do Departamento de Serviço Social do Centro de Ciências Sociais da PUC-Rio. Aprovado pela Comissão Examinadora abaixo assinada.
\end{abstract}

Profa. Valéria Pereira Bastos Orientadora

Departamento de Serviço Social - PUC-Rio

Prof. Rafael Soares Gonçalves Departamento de Serviço Social - PỦC-Rio

Profa. Tânia Horsth Noronha Jardim Departamento de Serviço Social - PUC-Rio

Prof. Elmo Rodrigues da Silva

Departamento de Engenharia Sanitária e do Meio Ambiente - UERJ

Profa. Cecília Campello do Amaral Mello Programa de Pós-Graduação em Planejamento Urbano e Regional IPPUR - UFRJ

Prof. Augusto Cesar da Silva Vice-Decano de Pós-Graduação do Centro de Ciências - PUC-Rio 
Todos os direitos reservados. É proibida a reprodução total ou parcial deste trabalho sem autorização da Universidade, do autor e da orientadora.

\section{Wanderson Antonio Vicente Jardim}

Graduou-se em Ciências Sociais pela Universidade Federal Fluminense, em 1999. Concluiu o mestrado pela Universidade Federal Fluminense em 2003. Atualmente desenvolve consultorias em projetos Socioambientais.

Ficha Catalográfica

Jardim, Wanderson Antonio Vicente

A Política Nacional De Resíduos Sólidos, seus avanços e retrocessos: uma análise a partir de sua implantação no município do Arraial do Cabo / Wanderson Antonio Vicente Jardim; orientadora: Valéria Pereira Bastos. - 2018.

262 f. : il. color. ; $30 \mathrm{~cm}$

Tese (doutorado) - Pontifícia Universidade Católica do Rio de Janeiro, Departamento de Serviço Social, 2018.

Inclui bibliografia.

1. Serviço Social - Teses. 2. Política Nacional de Resíduos Sólidos. 3. Desenvolvimento sustentável. 4. Vulnerabilidades. 5. Inclusão precária. 6. Justiça ambiental. I. Bastos, Valéria Pereira. II. Pontifícia Universidade Católica do Rio de Janeiro. Departamento de Serviço Social. III. Título. 
Dedico essa tese ao meu pai Almires Soares Jardim, Mirico, o meu eterno amor (in memorian), a minha mãe Marlene Jardim, por sua generosidade, apoio e amor incondicional, aos meus filhos Eduardo "Dudu" e Guilherme, razões do meu viver e fontes inspiradoras, que com um simples sorriso são capazes de fazer meu coração transbordar de alegria, à minha amada esposa Priscila Vogel, por sua dedicação à nossa família, por seu companheirismo e retaguarda mesmo nos momentos na qual tudo parecia impossível e aos catadores e as catadoras de materiais recicláveis de Arraial do Cabo e do Brasil, o elo mais frágil da cadeia produtiva da indústria da reciclagem. 


\section{Agradecimentos}

Para realizar este sonho foi necessário muito trabalho, empenho e superação de obstáculos. Entretanto essa conquista não seria possível sem a orientação, a presteza, o apoio, a compreensão e a solidariedade dos professores, familiares, amigos e profissionais responsáveis pela gestão dos resíduos. Esse agradecimento amplo tem a tarefa de me ajudar a não cometer injustiças, pois todos tiveram a sua relevância, seja numa discussão teórica e metodológica, num debate político ou até nas palavras de conforto e num singelo abraço de bem querer. A todos vocês espero que essas breves linhas demonstrem o meu sincero apreço e profunda gratidão.

Mas também se fazem necessários alguns agradecimentos especiais.

À minha orientadora Valéria Pereira Bastos pelos ensinamentos e análises sempre criteriosas e pela generosidade, liberdade e confiança a mim conferida para a realização deste trabalho.

Ao Professor Elmo Rodrigues da Silva pelas orientações de âmbito teórico e metodológico fundamentais para a estruturação da tese.

Ao Professor Rafael Soares Gonçalves pela análise arguta que muito contribuiu para o amadurecimento da tese, desde o período da qualificação.

À professora e amiga Cecília Campello do Amaral Mello pelas contribuições teóricas e pelo conforto nos momentos de maiores crises.

À Tânia Horsth Noronha Jardim pela disponibilidade e atenção.

Ao professor e amigo Andrey Cordeiro Ferreira, que com sua qualidade acadêmica e perspectiva crítica me auxiliou desde os primeiros passos nesta tortuosa jornada.

A todos os professores e funcionários do Programa de Pós Graduação em Serviço Social, que participaram da minha socialização acadêmica e amadurecimento intelectual. 
A CAPES porque o presente trabalho foi realizado com o apoio da Coordenação de Aperfeiçoamento de Pessoal de Nível Superior - Brasil (CAPES) - Código de Financiamento 001.

Aos gestores públicos de Arraial do Cabo, dirigentes do MNCR e do Eu Sou Catador e aos catadores da Cooperativa de Coleta e Reciclagem da Costa do Sol.

Ao pai "Mirico", ou simplesmente "Jurumbuga", um homem de muita fé e amor ao próximo, que me ensinou com a sua simplicidade e saber tradicional a amar e a respeitar a natureza, mostrando-me os seus encantos, segredos, saberes e limites, tão desvalorizados no mundo moderno, “onde tudo que é sólido se desmancha no ar". Essa dor hiperbólica e insuportável que parece uma queimadura na alma, causada pela sua ausência para sufocar o meu desespero e acalantar o meu coração, transformou-se em incentivo e força para terminar essa tese, repleta dos seus ensinamentos, como a luta pela defesa da natureza e por uma sociedade mais justa, igualitária, que valorize a dignidade, o respeito, a compreensão, a tolerância e que o "ser" valha mais do que o "ter" e que a essência seja mais dignificada do que a aparência.

A toda a minha família, especialmente ao meu irmão Alessandro, as minhas sobrinhas Beatriz, Victória e Alessandra, à minha filha do coração Vitória Vogel, aos meus sobrinhos emprestados Bruno e Lucas, a minha cunhada Rafaela e a minha prima Andréia pelo carinho, compreensão e suporte.

Ao Rodrigo Mendes, pela amizade, companheirismo, cumplicidade, apoio, lealdade e conforto nos momentos de aflição. Valeu irmão, sem você não chegaria até aqui.

À Thais, pela acolhida e pela força.

Ao amigo Max Prates, pelos debates e interlocução, pela revisão da tese e por ter sido um grande incentivador neste caminhar.

Ao Herick Simas, pelas contribuições e críticas relevantes desde a fase embrionária do projeto até as últimas linhas da tese.

À Monique Barreto, pela leitura atenta, dicas decisivas, ajuda na estruturação final da tese e pelo carinho.

Ao amigo Gláucio Maciel pelas discussões e sugestões fundamentais para o desenvolvimento da tese e também pelos momentos de lazer após as aulas.

Ao Gustavo Meirelles, pela força e carinho dispensados a mim e a minha família e por me mostrar que é possível fazer amizade depois de "velho". 
Ao Reginaldo Mendes, amigo de militância política e de vida por toda a força durante a tempestade.

À Viviane, Marcelo e seus filhos Bernardo e Guilherme que tornaram a nossa estadia no Rio de Janeiro mais fácil e prazerosa.

Aos amigos (as) de sempre e para toda vida, André Paquito, Arthur, Antônio, Bia, Camila, Caio Tricolor, Cappelli, Casé, Dedé, Diogo Martins, Diogo Volta, Felipe, Felipe Bebe, Fuia, Gut, Léo Tricolor, Léo Cabeça, Marcelo Amaral, Mazinho, Melch, Paulinho Tricolor, Rodrigo Branco, Rodrigo Pei, Sandrinho de Tata, Sérgio Fernandes, Virgínia, Tuca, Wálber e Zé Luís (in memorian).

Aos catadores e catadoras de materiais recicláveis da Cooperativa de Coleta e Reciclagem do Sol, especialmente a Val, com que muito aprendi sobre a vida e a luta destes profissionais.

Ao meu Fluminense, porque "haja o que houver, onde quer que eu vá, comigo vou levar as cores que herdei verde, branco e grená”. 


\section{Resumo}

Jardim, Wanderson Antonio Vicente; Bastos Valéria Pereira. A Política Nacional de Resíduos Sólidos, seus avanços e retrocessos: uma análise a partir de sua implantação no município do Arraial do Cabo. Rio de Janeiro, 2018. 262p. Tese do Doutorado - Departamento de Serviço Social. Pontifícia Universidade Católica do Rio de Janeiro.

O objetivo desta tese é investigar se a Política Nacional de Resíduos Sólidos contribui para a democrática inclusão social dos catadores e das catadoras de materiais recicláveis na gestão de resíduos ou se esse ordenamento jurídico que regula essa atividade econômica os inclui subalterna e precariamente, reforçando os processos de vulnerabilidades e de injustiças ambientais sobre estes trabalhadores. A pesquisa qualitativa teve como fio condutor de análise um estudo de caso sobre a implantação da política de resíduos sólidos no município de Arraial do Cabo, no Estado do Rio de Janeiro, no período compreendido entre 2009 e 2018. Adotamos como suporte para a descrição e a interpretação da realidade social investigada a pesquisa bibliográfica sobre os resíduos sólidos e a Política Nacional de Resíduos Sólidos, a revisão documental com ênfase na Auditoria Governamental na Prefeitura de Arraial do Cabo realizada em 2012 pelo TCE/RJ para verificar as condições de organização e funcionamento dos serviços de limpeza urbana e manejo dos resíduos sólidos e na Ação Civil Pública ${ }^{\circ}$ 0000412-67.2007.8.19.0005, promovida pelo Ministério Público em face do município do Arraial do Cabo e a análise da legislação ambiental voltada para a gestão e o gerenciamento dos resíduos sólidos. Utilizamos ainda como método de pesquisa as entrevistas semiestruturadas com os principais atores sociais responsáveis pela gestão dos resíduos, a saber: dirigentes e catadores e catadoras da Cooperativa de Coleta e Reciclagem da Costa do Sol; poder público, representado pela Secretaria Municipal de Ambiente e Fundação Municipal de Meio Ambiente, Pesquisa, Ciência e Tecnologia; dirigentes do Movimento Nacional dos Catadores - MNCR e do Movimento Nacional Eu Sou Catador de Materiais Recicláveis - MESC. Ao investigar o planejamento, a avaliação, a fiscalização, a transparência e o monitoramento das ações governamentais no que tange à gestão e ao gerenciamento de resíduos sólidos em Arraial do Cabo, concluímos que a política de resíduos trouxe melhorias socioambientais para o 
município. Contudo, ela conduziu a uma inclusão precária dos catadores e catadoras de materiais recicláveis, pois não produziu mecanismos que evitassem a distribuição desigual de proteção social, causadora dos processos de vulnerabilidades, assim como ela não foi construída conectando a sustentabilidade ambiental à cidadania e a formas de atuação democráticas e promotoras da justiça ambiental.

\section{Palavras-chave}

Política Nacional de Resíduos Sólidos; Desenvolvimento Sustentável; Vulnerabilidades; Inclusão Precária; Justiça Ambiental. 


\section{Abstract}

Jardim, Wanderson Antonio Vicente; Bastos, Valéria Pereira (Advisor) . The National Solid Waste Policy, its advances and stebacks: an analysis of its implantation in the municipality of Arraial do Cabo. Rio de Janeiro, 2018. 262p. Tese de Doutorado - Departamento de Serviço Social. Pontifícia Universidade Católica do Rio de Janeiro.

The aim of this thesis is to investigate whether the National Solid Waste Policy contributes to the democratic social inclusion of recyclable waste pickers in waste management, or whether such legal system that regulates this economic activity includes them subalternly and precariously, reinforcing their vulnerabilities and environmental injustices. This qualitative research was based on a case study on the implementation of solid waste policy in the city of Arraial do Cabo, in the State of Rio de Janeiro, between 2009 and 2018. We took as a support for the description, and interpretation of the social reality investigated the bibliographic research on solid waste and the National Solid Waste Policy, the documentary review with emphasis on the Government Audit in the Municipality of Arraial do Cabo held in 2012 by TCE/RJ to verify the conditions of organization and operation of the services of urban cleaning and solid waste management and in the Public Civil Action $\mathrm{n}^{\mathrm{o}}$ 000041267.2007.8.19.0005, promoted by the Public Ministry in face of the municipality of Arraial do Cabo and the analysis of the environmental legislation towards the management of solid waste. We also used as a research method semi-structured interviews with the main social actors responsible for waste management, namely: managers and waste pickers of the Cooperative of Collection and Recycling of the Costa do Sol; the public authority, represented by the Municipal Secretariat the Municipal Environment Secretariat and the Municipal Foundation for Environment, Research, Science and Technology, the leaders of the National Collectors Movement and the National Movement I Am Collector of Recyclable Materials. By investigating the planning, evaluation, supervision, transparency and monitoring of governmental actions regarding the solid waste management in Arraial do Cabo, we concluded that the waste policy led to socioenvironmental improvements to the municipality. However it resulted in a precarious inclusion of recyclable waste pickers because it did not produce mechanisms to avoid unequal 
distribution of social protection, causing vulnerability processes, besides the fact that it was not built connecting environmental sustainability to citizenship and to democratic and environmentally just ways of acting.

\section{Keywords}

National Solid Waste Policy; Sustainable Development; Vulnerabilities; Precarious inclusion; Environmental Justice. 


\section{Sumário}

1. Introdução

2. A história do pensamento ambientalista e seus rebatimentos políticos na atualidade

2.1. O Pós-Segunda Guerra Mundial e a Eclosão do Ambientalismo 49

2.2. O Relatório "Limites do Crescimento" e as polêmicas do Crescimento Zero

2.3. Da Conferência de Estocolmo à Rio+20: do desenvolvimentismo ao Desenvolvimento Sustentável

3. A Política Nacional de Resíduos Sólidos no Brasil: fragilidades, contradições, limites e possibilidades

3.1. O Estado da Arte dos Resíduos Sólidos e da Política Nacional de Resíduos Sólidos - PNRS

3.2. Um pouco de história da Política Nacional de Resíduos Sólidos .118

3.3. As fragilidades, contradições, limites e possibilidades da Política Nacional de Resíduos Sólidos

4. O Município de Arraial do Cabo e a Política Nacional de Resíduos Sólidos.. 159

4.1. O município do Arraial do Cabo e o panorama dos resíduos sólidos antes e depois da Política Nacional de Resíduos Sólidos.................................. 160

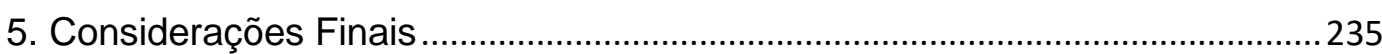

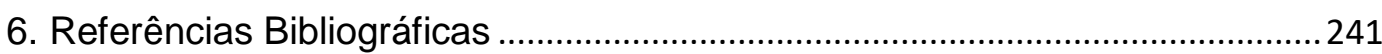

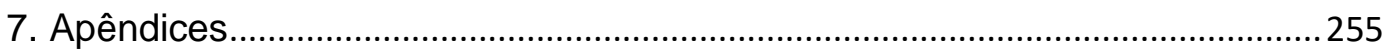

Apêndice 1: Termo de Consentimento Livre e Esclarecido..................................255

Apêndice 2: Roteiro de entrevista com os catadores da Cooperativa de Coleta e Reciclagem da Costa do Sol.

Apêndice 3: Roteiro de entrevista com os catadores da Cooperativa de Coleta e Reciclagem da Costa do Sol.

Apêndice 4: Roteiro de entrevista com os dirigentes do movimento dos catadores de materiais recicláveis

Apêndice 5: Roteiro de entrevista com os gestores públicos 


\section{Lista de figuras}

Figura 1- Percentual de municípios com Plano de Gestão Integrada de Resíduos

Figura 2 - Município que declararam possuir Plano de Gestão

Integrada de Resíduos Sólidos.

Figura 3 - Situação dos Planos de Gestão Integrada de Resíduos dos municípios

Figura 4 - Municípios com coleta seletiva por região

Figura 5 - Coleta seletiva nos municípios por regiões

Figura 6 - Tipo de disposição final no Brasil (t/dia)

Figura 7 - Tipo de disposição final no Brasil (t/ano)

Figura 8 - Mapa do Brasil, do Rio de Janeiro e da Região das

Baixadas Litorâneas

Figura 9 - Localização de Arraial do Cabo e seus limites, localização do município no Estado do Rio de Janeiro e no Brasil e suas praias 159 Figura 10 - Acesso ao município de Arraial do Cabo 160

Figura 11- Galpão da Usina de Reciclagem 166

Figura 12 - Peneira Rotativa da Usina de Reciclagem

Figura 13 - Galpão de Triagem em operação da Usina de Reciclagem em 1992

Figura 14 - Funcionários da prefeitura trabalhando no Galpão de Triagem da Usina de Reciclagem

Figura 15 - Esteira e Prensa em más condições na Usina de Reciclagem de Arraial do Cabo

Figura 16 - Rampa para recepção dos caminhões em precárias condições

Figura 17 - Processo deficiente de Compostagem

Figura 18 - Foto aérea da Usina de Reciclagem

Figura 19 - Área adjacente à Usina de Reciclagem no município

De Arraial do Cabo

Figura 20 - Lixão de Arraial do Cabo 189

Figura 21 - Lixão de Arraial do Cabo 189

Figura 22 - Lixão de Arraial do Cabo 
Figura 23 - Início das obras de reforma e ampliação da Usina de Reciclagem 200

Figura 24 - Construção do Prédio Administrativo 202

Figura 25 - Vistoria da Comissão Especial da ALERJ, em 24 de maio de 2013 no lixão de Arraial do Cabo 204

Figura 26 - Construção do Prédio Administrativo da Usina de Reciclagem de Arraial do Cabo 208 Figura 27 - Construção do Prédio Administrativo da Usina de Reciclagem de Arraial do Cabo 208

Figura 28 - Prédio Administrativo sendo usado pelos catadores e catadoras da Cooperativa de Coleta e Reciclagem da Costa do Sol

Figura 29 - Entrada da Usina de Reciclagem e do Galpão de Reciclagem de Arraial do Cabo

Figura 30 - Rampa de Acesso ao Galpão de Triagem e o Galpão de Reciclagem de Resíduos da Construção Civil da Usina de Reciclagem de Arraial do Cabo

Figura 31 - Galpão de Triagem da Usina de Reciclagem

Figura 32 - Galpão e Pátio de Compostagem da Usina de Reciclagem de Arraial do Cabo

Figura 33 - Galpões com os maquinários 


\section{Lista de tabelas}

Tabela 1: Situação dos municípios quanto à coleta seletiva de materiais recicláveis

Tabela 2: Destinação final dos resíduos, por unidades de destino dos resíduos no Brasil - 1989 - 2008 150

Tabela 3: Quantidade de unidades de processamento de RSU 


\section{Lista de siglas e abreviaturas}

ABES - Associação Brasileira de Engenharia Sanitária

ABETRE - Associação Brasileira de Empresa de Tratamento de Resíduos e Efluentes

ABIPET - Associação Brasileira de Indústria Pet

ABLP - Associação Brasileira de Resíduos e Limpeza Urbana

ABNT - Associação Brasileira de Normas Técnicas

ABRAMPA - Associação Brasileira dos Membros de Ministério Público de Meio Ambiente

ABRELPE - Associação Brasileira de Empresas de Limpeza Pública

AMJG - Aterro Metropolitano de Jardim Gramacho

ANIP - Associação Nacional da Indústria de Pneumáticos

BNDES - Banco Nacional de Desenvolvimento Econômico e Social

CBO - Classificação Brasileira de Ocupação

CDB - Convenção sobre Diversidade Biológica

CEF - Caixa Econômica Federal

CEMPRE - Compromisso Empresarial para Reciclagem

CEPAL - Comissão Econômica para a América Latina

CGU - Controladoria da Geral da União

CIEC - Coordenação Interestadual de Ecologistas para a Constituinte

CIISC - Comitê Interministerial de Inclusão Social de Catadores Materiais

Recicláveis

CMMAD - Comissão Mundial para o Meio Ambiente e Desenvolvimento

$\mathrm{CNI}$ - Confederação Nacional das Indústrias

CNM - Confederação Nacional de Municípios

CNPA - Conselho Nacional de Política Agrícola

COMECON - Conselho para Assistência Econômica Mútua

CONAMA - Conselho Nacional de Meio Ambiente

CORI - Comitê Orientador para a Implantação dos Sistemas de Logística

Reversa

CUT - Central Única dos Trabalhadores

DENSP - Departamento de Engenharia de Saúde Pública 
DIRUR - Diretoria de Estudos e Políticas Regionais, Urbanas e Ambientais

ECATUR - Empresa Cabista de Desenvolvimento Urbano e Turismo

EUA - Estados Unidos da América

FECAN - Fundo Estadual de Conservação Ambiental e Desenvolvimento

Urbano

FEEMA - Fundação Estadual de Engenharia do Meio Ambiente

FIESP - Federação das Indústrias do Estado de São Paulo

FMMAPCT - Fundação Municipal de Meio Ambiente, Pesquisa, Ciência e

Tecnologia

FUNASA - Fundação Nacional de Saúde

IBAM - Instituto Brasileiro de Administração Municipal

IBGE- Instituto Brasileiro de Opinião Pública e Estatística

IDHM - Índice de Desenvolvimento Humano Municipal

IEE - Instituto de Energia e Ambiente

INEA - Instituto Estadual do Ambiente

IPCC - Painel Intergovernamental sobre Mudanças Climáticas

IPEA - Instituto de Pesquisa Econômica Aplicada

IPPUR - Instituto de Pesquisas e Planejamento Urbano

ITP - Instituto de Pesquisas Tecnológicas

MAPA - Ministério da Agricultura, Pecuária e Abastecimento

MCCidades - Ministério das Cidades

MCT - Ministério da Ciência e Tecnologia

MDL - Mecanismo de Desenvolvimento Limpo

MDS - Ministério do Desenvolvimento Social e Combate à Fome

MESC - Movimento Eu Sou Catador

MET - Ministério do Trabalho e Emprego

MIT - Massachusetts Institute of Technology

MMA - Ministério do Meio Ambiente

MME - Ministério de Minas e Energia

MNCR - Movimento Nacional dos Catadores de Materiais Recicláveis

MPF - Ministério Público Federal

MPRJ - Ministério Público do Estado do Rio de Janeiro

MS - Ministério da Saúde 
OAB - Ordem dos Advogados do Brasil

ODM - Objetivos de Desenvolvimento do Milênio

ONU - Organização das Nações Unidas

OPNRS - Observatório da Política Nacional de Resíduos Sólidos

OTAN - Comitê Econômico da Organização do Tratado do Atlântico Norte

PUC- Rio - Pontifícia Universidade Católica Rio de Janeiro

PNRS - Política Nacional de Resíduos Sólidos

PNSB - Pesquisa Nacional de Saneamento Básico

PNUMA - Programa das Nações Unidas para o Meio Ambiente

PAC - Programa de Aceleração de Crescimento

RBJA - Rede Brasileira de Justiça Ambiental

SEDU - Secretaria Especial de Desenvolvimento Urbano da Presidência da República

SELURB - Sindicatos das Empresas de Limpeza Urbana

SEMA/AC - Secretaria Especial de Meio Ambiente

SENAES - Secretaria Nacional de Economia Solidária

SIGOB - Sistema Integrado der Monitoramento de Convênios

SINIMA - Sistema Nacional de Informações sobre Meio Ambiente

SNIS - Sistema Nacional de Informações sobre Saneamento

SINISA - Sistema Nacional de Informações sobre Saneamento Básico

SISNAMA - Sistema Nacional de Meio Ambiente

SNSA - Secretaria Nacional de Saneamento Ambiental

SNVS - Sistema Nacional de Vigilância Sanitária

SRHU - Secretaria de Recursos Hídricos e Ambiente Urbano

SUASA - Sistema Unificado de Atenção à Sanidade Agropecuária

TCE/RJ - Tribunal de Contas do Estado do Rio de Janeiro

TCU - Tribunal de Contas da União

UNCCD - Convenção das Nações Unidas de Combate à Desertificação

UNCRD - Comissão das Nações Unidas para o Desenvolvimento

Regional

UNFCCC - Convenção Quadro das Nações Unidas sobre Mudança do Clima

UNICEF - Fundo das Nações Unidas para a Infância

URSS - União das Repúblicas Socialistas Soviéticas 
"Há uma mulher no lixo

Sorrindo de verdade (ela sorri no

lixo)

Ela cata detritos e sorri seu sorriso

Quando lhe perguntam por que sorri no lixo

Ela diz que sorri porque éfeliz

- Como ousas mulher ser feliz?

Perguntam à mulher encontrada no

lixo

Mas seu sorriso existe e ela sorri no

lixo

Ela se dizfeliz (como ousas?)

Há uma mulher no luxo

Simulando um sorriso

Parece estar sorrindo, mas simula o

sorriso

Encontrada no luxo ela simula o

sorriso

Nada lhe é perguntado

Nada lhe é perguntado sobre seu

sorriso

Porque se está no luxo sorrindo, mas

é um sorriso fingindo

Certamente sorri por ser feliz".

(Eraldo Amay) 


\section{Introdução}

A Lei $\mathrm{n}^{\mathrm{o}}$ 12.305, de 02 de agosto de 2010, instituiu a Política Nacional de Resíduos Sólidos - PNRS (BRASIL, 2010a) e estabeleceu um conjunto de princípios, objetivos e instrumentos, bem como diretrizes relativas à gestão e ao gerenciamento de resíduos sólidos, estando sujeitas à sua observância as pessoas físicas ou jurídicas, de direito público ou privado, responsáveis, direta ou indiretamente, pela geração de resíduos sólidos e as que desenvolvam ações relacionadas à gestão integrada ou ao gerenciamento de resíduos sólidos. Esta lei foi regulamentada pelo Decreto $\mathrm{n}^{\mathrm{o}}$ 7.404, de 23 de dezembro de 2010 (BRASIL, 2010b) que criou o Comitê Interministerial da Política Nacional de Resíduos Sólidos e o Comitê Orientador para a Implantação dos Sistemas de Logística Reversa.

O Comitê Interministerial da Política Nacional de Resíduos Sólidos tem como finalidade apoiar a estruturação e a implantação da Política Nacional de Resíduos Sólidos, por meio da articulação dos órgãos e entidades governamentais, de modo a possibilitar o cumprimento das determinações e das metas previstas na Lei $n^{o}$ 12.305, de 2010 e no próprio Decreto. Já ao Comitê Orientador para Implantação de Sistemas de Logística Reversa compete estabelecer a orientação estratégica da implantação de sistemas de logística reversa, definindo prioridades e aprovando o cronograma para o lançamento de editais de chamamento de propostas de acordo setorial para a implantação de sistemas de logística reversa de iniciativa da União.

A Constituição Federal de 1988 (BRASIL, 1988) incumbiu ao Distrito Federal e aos Municípios a gestão integrada dos resíduos sólidos gerados nos respectivos territórios, fator corroborado pela PNRS/2010, sem prejuízo das competências de controle e fiscalização dos órgãos federais e estaduais do Sistema Nacional do Meio Ambiente - SISNAMA, do Sistema Nacional de Vigilância Sanitária - SNVS e do Sistema Unificado de Atenção à Sanidade Agropecuária SUASA, bem como a responsabilidade dos geradores e do poder público, com vistas à gestão integrada e ao gerenciamento ambientalmente adequado dos resíduos sólidos. 
A gestão integrada na PNRS foi definida como o conjunto de ações voltadas para a busca de soluções para os resíduos sólidos, com controle social ${ }^{1}$ e sob a premissa da sustentabilidade. Já o gerenciamento ambientalmente adequado dos resíduos sólidos foi definido como o conjunto de ações exercidas direta ou indiretamente nas etapas de coleta, transporte, transbordo, tratamento, destinação final ambientalmente adequada dos resíduos sólidos e disposição final ambientalmente adequada dos rejeitos, de acordo com plano municipal de gestão integrada de resíduos sólidos ou com plano de gerenciamento de resíduos sólidos.

A PNRS estabeleceu como princípio uma visão sistêmica e sustentável na gestão dos resíduos sólidos que considere as variáveis ambiental, social, cultural, econômica, tecnológica e de saúde pública e o reconhecimento do resíduo sólido reutilizável e reciclável como um bem econômico e de valor social, gerador de trabalho e renda e promotor de cidadania. Para tanto, definiu como condicionante a cooperação entre as diferentes esferas do poder público, do setor empresarial e demais segmentos da sociedade na responsabilidade compartilhada pelo ciclo de vida dos produtos.

Como objetivos a PNRS instituiu a proteção da saúde pública e da qualidade ambiental, o estímulo à adoção de padrões sustentáveis de produção e consumo de bens e serviços e a não geração, a redução, a reutilização, a reciclagem, o tratamento dos resíduos sólidos e a disposição final ambientalmente adequada dos rejeitos. Assim como a regularidade, a continuidade, a funcionalidade e a universalização da prestação dos serviços públicos de limpeza urbana e de manejo dos resíduos sólidos, a adoção, o desenvolvimento, a capacitação técnica continuada na área de resíduos sólidos e o aprimoramento de tecnologias limpas como forma de minimizar impactos ambientais.

Para alcançar esses objetivos, a PNRS estabeleceu dentre outros instrumentos os planos de resíduos sólidos, a coleta seletiva, os sistemas de logística reversa e outras ferramentas relacionadas à implantação da responsabilidade compartilhada pelo ciclo de vida dos produtos, os acordos setoriais, a educação ambiental, o incentivo à criação e ao desenvolvimento de cooperativas ou de outras formas de associação de catadores e de catadoras de

\footnotetext{
${ }^{1} \mathrm{O}$ controle social de acordo com a lei $\mathrm{n}^{\mathrm{o}} 12.305 / 10$ é conjunto de mecanismos e procedimentos que garantam à sociedade informações e participação nos processos de formulação, implantação e avaliação das políticas públicas relacionadas aos resíduos sólidos.
} 
materiais reutilizáveis e recicláveis, a cooperação técnica e financeira entre os setores público e privado para o desenvolvimento de pesquisas de novos produtos, métodos, processos e as tecnologias de gestão e o Sistema Nacional de Informações sobre a Gestão dos Resíduos Sólidos - SINIR.

Com a finalidade de integrar e articular as ações do Governo Federal voltadas ao apoio e ao fomento à organização produtiva dos catadores e das catadoras de materiais reutilizáveis e recicláveis ${ }^{2}$, à melhoria das condições de trabalho, à ampliação das oportunidades de inclusão social e econômica e à expansão da coleta seletiva de resíduos sólidos, da reutilização e da reciclagem por meio da atuação desse segmento foi instituído o Programa Pró-Catador (BRASIL, 2010c).

O Programa Pró-Catador objetiva assim promover a capacitação, a formação e a assessoria técnica dos catadores e das catadoras de materiais reutilizáveis e recicláveis, a incubação de cooperativas e de empreendimentos sociais solidários que atuem na reciclagem, as pesquisas e estudos para subsidiar ações que envolvam a responsabilidade compartilhada pelo ciclo de vida dos produtos, a aquisição de equipamentos, máquinas e veículos voltados para a coleta seletiva, reutilização, beneficiamento, tratamento e reciclagem pelas cooperativas e associações de catadores e catadoras de materiais reutilizáveis e recicláveis e a implantação e adaptação de infraestrutura física de cooperativas e associações de catadores e catadoras de materiais reutilizáveis e recicláveis.

Além desses objetivos tem como finalidade também promover a organização e apoio a redes de comercialização e cadeias produtivas integradas por cooperativas e associações de catadores e de catadoras de materiais reutilizáveis e recicláveis, o fortalecimento da participação do catador e da catadora de materiais reutilizáveis e recicláveis nas cadeias de reciclagem, o desenvolvimento de novas tecnologias voltadas à agregação de valor ao trabalho de coleta de materiais reutilizáveis e recicláveis e a abertura e manutenção de linhas de crédito especiais para apoiar projetos voltados à institucionalização e fortalecimento de cooperativas e associações de catadores e catadoras de materiais reutilizáveis e recicláveis.

\footnotetext{
${ }^{2}$ Para os fins deste Decreto, consideram-se catadores de materiais reutilizáveis e recicláveis as pessoas físicas de baixa renda que se dedicam às atividades de coleta, triagem, beneficiamento, processamento, transformação e comercialização de materiais reutilizáveis e recicláveis. (BRASIL, 2010c).
} 
Mas após oito anos da promulgação da PNRS e dos referidos Decretos, há uma série de indagações a serem formuladas sobre as fragilidades relacionadas à sua implantação no país, em particular para a inclusão social e econômica dos catadores e das catadoras de materiais recicláveis na gestão e no gerenciamento dos resíduos sólidos.

Objetivando contribuir para a reflexão sobre as fragilidades, os limites e as possibilidades da PNRS, analisamos a política de resíduos sólidos implantada pelo município do Arraial do Cabo. Para tanto, fez-se necessário elencar alguns questionamentos, a saber:

O Plano Municipal de Resíduos Sólidos foi concluído e publicado? Se o foi qual a participação dos catadores e das catadoras de materiais recicláveis na sua construção e execução?

O município realiza a destinação final adequada de resíduos com a reutilização, a reciclagem e a compostagem?

Há a disposição adequada dos resíduos em aterros sanitários?

O município possui lixão? Se sim, ele está operando?

Os sistemas de logística reversa e outras ferramentas relacionadas à implantação da responsabilidade compartilhada pelo ciclo de vida dos produtos ocorrem?

Existe o apoio técnico, orçamentário e financeiro nas áreas de gestão de empreendimentos sociais, educação ambiental e coleta seletiva voltada à inclusão social e a emancipação econômica dos catadores e das catadoras de materiais recicláveis?

O município mantém atualizados os dados referentes à gestão dos resíduos?

Partindo desses questionamentos analisamos o planejamento, a avaliação, a fiscalização, a transparência e o monitoramento das ações governamentais no que tange à gestão e ao gerenciamento de resíduos sólidos em Arraial do Cabo, procurando responder se a Política de Resíduos Sólidos no município contribui para a democrática inclusão social dos catadores e das catadoras de materiais recicláveis na gestão de resíduos ou se esse ordenamento jurídico que regula essa atividade econômica os inclui subalterna e precariamente, reforçando os processos de vulnerabilidades e laços de dependência.

Isto é, até que ponto a Política de Resíduos Sólidos no município do Arraial do Cabo contribui para o processo de justiça ambiental, com efetiva participação 
dos catadores e das catadoras de materiais recicláveis no processo de gestão. $\mathrm{Ou}$ até que ponto esse arcabouço jurídico na prática contribui para incluí-los precariamente, reforçando mecanismos e processos de vulnerabilidades e de injustiças ambientais sobre esses trabalhadores.

Temos como pressupostos que a Política de Resíduos Sólidos trouxe melhorias socioambientais para o município e para os catadores e as catadoras de materiais recicláveis, contudo ela não conduzirá à sua efetiva inclusão social se não houver uma ruptura com o paradigma dominante, centrado na lógica do mercado, que não permite ver a sustentabilidade ambiental conectada à construção da cidadania e a formas de atuação democráticas, inclusivas, participativas e promotoras da justiça ambiental.

Pressupomos também, que sem a ruptura com os mecanismos de distribuição desigual de proteção social, causadores dos processos de vulnerabilidades sobre os mais pobres e sem poder e recursos financeiros permanecerá ocorrendo uma inclusão precária dos catadores e das catadoras de materiais recicláveis, sem que esses trabalhadores tenham assegurado um conjunto de benefícios sociais, o que comprometerá inclusive a sua dignidade como pessoa humana.

A categoria vulnerabilidade não foi trabalhada nesta tese como vinculada às suscetibilidades do sujeito social aos agravos ou à sua incapacidade de defesa diante desses, mas sim como um processo de proteção desigual do Estado, que imprime riscos ambientais desproporcionais aos despossuídos de poder político e econômico e com menos potencial de se fazer ouvir na esfera pública. Sendo assim, seguimos a perspectiva apontada por Acselrad (2006) que abordou as condições de vulnerabilidade como uma questão de direitos humanos, vinculandoas às suas raízes sociais mais profundas, estimulando e potencializando a mobilização dos sujeitos sociais para a transformação destas condições.

$\mathrm{Na}$ nossa reflexão não adotamos a categoria analítica exclusão social. Esta opção teórica decorreu da concordância com a perspectiva de Martins (2007) sobre a generalidade da categoria exclusão social e da necessidade de superar o seu uso para explicar todas as formas de subalternização, marginalização, estigmatização, discriminação, desqualificação ou pobreza.

Segundo o autor, o excluído não é uma classe social e nem uma categoria sociológica substantiva, relativa ao efetivo e objetivo sujeito social e histórico. 
Assim, o "excluído" é um rótulo abstrato, que não corresponde a nenhum sujeito. Desse modo, a categoria exclusão, não pode ser utilizada para compreender o social, pois não toca nas contradições.

Martins (2007) desconstrói teoricamente o conceito de exclusão social mostrando que há uma leitura equivocada, que escamoteia o processo histórico de exclusão. Para o autor, o que existe é contradição, vítimas de processos sociais, políticos e econômicos excludentes. Portanto, a questão que deve ser problematizada são as formas marginais, deficientes, instáveis e precárias pelas quais a sociedade pretende gerar inclusão, negligenciando os direitos dos cidadãos.

Martins (2007) questiona ainda a dicotomia entre incluídos em oposição aos excluídos. Segundo ele, essa construção dualista não considera a lógica da sociedade capitalista de tudo desenraizar e a todos excluir, porque tudo deve ser lançado no mercado, ou seja, a lógica exclui para depois incluir de forma precária, marginal e instável. É nesse cenário que sugere a existência de uma sociedade dupla, com duas humanidades, uma constituída de integrados, com uma população de pobres e ricos inseridos nas atividades econômicas e com lugar no sistema de relações sociais e políticas e uma sub-humanidade, incorporada por meio do trabalho precário.

Essa análise oferecida pelo autor nos auxiliou a pensar a inclusão dos catadores e das catadoras de materiais recicláveis, por meio da Política de Resíduos Sólidos, que os inclui no processo de produção de mercadoria, mas os exclui do universo social.

Consideramos que o objeto discutido nesta pesquisa seja relevante no sentido de contribuir com a ampliação de estudos acadêmicos em função de poder oferecer aos interessados pela temática, mais informações que apontem os limites e as possibilidades da inclusão democrática dos catadores e das catadoras de materiais recicláveis, por meio da Política Nacional de Resíduos Sólidos.

Apoiado nos princípios da ecologia política e da justiça ambiental, acreditamos contribuir para preencher lacunas, evidenciando que embora haja um arcabouço legal para efetiva aplicação da Política Nacional de Resíduos Sólidos e para a participação dos catadores e das catadoras de materiais recicláveis no processo de gestão, na prática o que ocorre é que este segmento sucumbe à lógica sistêmica, que corrobora com mecanismos de injustiças ambientais, reforçando os 
processos de vulnerabilidades e os laços de dependência desses sujeitos junto à administração pública.

O interesse pela discussão acerca dos dilemas da gestão e do gerenciamento dos resíduos sólidos iniciou-se em janeiro do ano de 2009, ao assumirmos a direção da Fundação Municipal de Meio Ambiente, Pesquisa, Ciência e Tecnologia do município de Arraial do Cabo ${ }^{3}$.

Naquele momento, ocupando a posição de gestor público deparamo-nos com um cenário ambiental complexo no que tange à gestão e ao gerenciamento de resíduos sólidos urbanos, em função da ausência de uma política pública voltada a esse setor, o que agravava o quadro de conflitos socioambientais nos espaços públicos do município.

Essa experiência enquanto gestor público, que foi uma das principais motivações para o desenvolvimento desta pesquisa, nos permitiu perceber muitos dos obstáculos, fragilidades, limites e possibilidades quanto à gestão dos resíduos sólidos urbanos no Brasil, assim como os desafios colocados aos municípios e à sociedade para a implantação dessa políticavb pública.

Inicialmente, pretendíamos analisar uma parte específica da gestão de resíduos sólidos no município, a saber: os efeitos da reforma e da ampliação da Usina de Reciclagem para o cenário socioambiental do município, particularmente o impacto sobre o ecossistema de restinga e sua biodiversidade, bem como sobre a vida e o trabalho dos 48 (quarenta e oito) catadores e catadoras de materiais recicláveis da Cooperativa de Coleta e Reciclagem da Costa do Sol.

A escolha do objeto de estudo dentre as possibilidades existentes possuía razões variadas. Primeiramente, por uma questão identitária, por sermos "nativos" de Arraial do Cabo e, portanto, com o “cordão umbilical” ligado ao lócus da pesquisa. Em segundo, pela experiência enquanto gestor público do município o que possibilitaria contato com os mais variados atores sociais envolvidos na gestão dos resíduos sólidos, entre eles o poder público, os catadores e as catadoras de materiais recicláveis, os dirigentes da Cooperativa de Coleta e Reciclagem da Costa do Sol e a sociedade cabista. E, por fim, e não menos importante, pela possibilidade de contribuir, a partir da nossa reflexão, para possíveis caminhos

\footnotetext{
${ }^{3}$ Trata-se de uma entidade pública municipal, sem fins lucrativos, criada por meio da Lei $\mathrm{n}^{\circ} 1.263$ de 03 de setembro de 2002, que possui como objetivo central a elaboração de projetos ambientais para serem executados pelo município.
} 
para a gestão e o gerenciamento integrado dos resíduos sólidos urbanos no município de Arraial do Cabo e no Brasil, podendo servir como referência posteriormente.

No entanto, percebemos no doutorado a necessidade de redimensionar o objeto da pesquisa, em função do seu alcance e relevância. Notamos que pensar apenas uma parte específica dessa política pública no município seria restrito e limitado, sendo necessário expandir a análise para toda política de gestão e de gerenciamento dos resíduos sólidos no território de Arraial do Cabo, o que incluiria, evidentemente, a reforma e ampliação da Usina de Reciclagem e os seus desdobramentos.

As alterações no recorte do objeto da pesquisa não pararam por aí, tendo em vista que os debates desenvolvidos nas disciplinas do doutorado ampliaram ainda mais a nossa perspectiva nos fazendo pensar a política pública de resíduos sólidos na esfera municipal em sua interdependência com o cenário nacional, assim como a sua conexão com os valores culturais da sociedade de consumo, do modo de produção capitalista e dos aspectos políticos e econômicos da questão resíduos.

A mudança de abordagem se consolidou no primeiro semestre de 2017, quando cursamos a disciplina “Tópicos Especiais em Serviço Social: Questão Ambiental e Trabalho Social", ministrada pela professora doutora Valéria Bastos, na qual discutimos as variadas dimensões do trabalho social e sua interface com as ações socioambientais, principalmente as que buscam enfrentar as desigualdades sociais proporcionadas pela precarização do trabalho.

Outro fator de fundamental relevância para o novo direcionamento da pesquisa está ligado aos debates realizados com a nossa orientadora sobre os impactos socioeconômicos na vida dos catadores e das catadoras de materiais recicláveis, após o encerramento do Aterro Metropolitano de Jardim Gramacho, mais conhecido como Lixão de Gramacho4.

De acordo com Bastos (2015), o encerramento do lixão de Gramacho, sem a incorporação dos catadores e das catadoras de materiais recicláveis no sistema de gestão de resíduos de forma justa e financeiramente sustentável, ao invés de cumprir sua função de favorecer o meio ambiente e a população, trouxe inúmeras

\footnotetext{
${ }^{4}$ Identificado como o maior aterro da América Latina ocupando uma área de 1,3 milhão de $\mathrm{m}^{2}$, situada às margens da Baía de Guanabara no sub-bairro de Jardim Gramacho, no município de Duque de Caxias.
} 
desvantagens, piorando as já precárias condições de saúde, segurança, trabalho, e relegando-as à marginalidade refletida pela sua invisibilidade por parte dos demais ocupantes do espaço urbano público.

Bastos (2015) apontou para a necessidade do fornecimento de recursos para a remuneração do trabalho, infraestrutura, capacitação e assistência técnica para a garantia de dignidade desses trabalhadores, pois caso isso não acontecesse, os catadores e catadoras dos lixões, além de perderem as suas referências laborais, continuariam desempregados e vivendo em condições mais precarizadas do que no passado, pois se antes o risco ambiental era iminente pela condição do trabalho, com a finalização das atividades do "lixão" a situação de risco social se tornaria evidente.

Essa reflexão contribuiu para a construção de novos horizontes e perspectivas de análise. Na esteira de sua argumentação começamos a questionar se o fechamento dos lixões, sem o apoio aos catadores e às catadoras de materiais recicláveis não seria uma forma de gestão ambiental que desconecta a sustentabilidade ambiental da sustentabilidade social. Em outras palavras, começamos a problematizar se o fechamento dos lixões desconectado da sustentabilidade social não seria mais uma forma de reforçar os mecanismos de injustiça ambiental.

A problematização sobre a gestão dos resíduos sólidos, vinculada a nossa experiência enquanto gestor público nos impulsionou a refletir mais amplamente sobre a Política Nacional dos Resíduos Sólidos e seus dilemas, limites e possibilidades.

Apesar de acreditar como apontou Minayo (2002) que nas Ciências Sociais sempre há uma identidade entre sujeito e objeto ainda permanecia uma dificuldade, qual seja realizar um estudo sobre a implantação de uma política pública na qual o próprio pesquisador fazia parte da gestão a ser analisada. Somado a essa dificuldade de cunho epistemológico, em fevereiro de 2017, após oito anos à frente da Fundação Municipal de Meio Ambiente, Pesquisa, Ciência e Tecnologia, nos mudamos de Arraial do Cabo para o bairro da Tijuca, no município do Rio de Janeiro.

Perante esse novo cenário, em abril de 2017 optamos por analisar, a partir de um estudo de caso no município do Rio de Janeiro, se a Política Nacional de Resíduos Sólidos contribui para a democrática inclusão social dos catadores e das 
catadoras de materiais recicláveis ou para a sua inclusão subalterna e precária, reforçando os processos de vulnerabilidades e de injustiças ambientais.

\subsection{Metodologia}

A opção pelo estudo de caso, um método de pesquisa empírica, que investiga um fenômeno atual dentro do seu contexto de realidade (YIN, 2001, p. 32) ocorreu porque avaliamos que por meio dessa técnica, caracterizada pelo estudo aprofundado de um caso particular, seria possível melhorar a definição do problema e o delineamento da pesquisa, assim como realizar a coleta dados, a análise de dados e a composição dos resultados com mais sistematicidade e precisão. Além desse aspecto, o estudo de caso possibilitaria lidar com uma variedade de fontes de evidências, entre elas os documentos, as entrevistas e as observações que, consequentemente, permitiriam um encadeamento de evidências, isto é, ligações explícitas entre as questões feitas, os dados coletados e as conclusões (YIN, 2001. p. 101).

Segundo Yin (2001), entretanto, o pesquisador para realizar um estudo de caso consistente deverá ter a noção cristalina da questão investigada para fazer boas perguntas, ser um atento ouvinte e não se enganar por suas próprias ideologias e preconceitos, ser flexível considerando as situações encontradas como oportunidades e estar vigilante a provas contraditórias.

É imprescindível destacar que, o método de estudo de caso sofre resistência de muitos autores. Tal fato é decorrente de uma visão estereotipada, que aponta para a falta de rigor metodológico, a dificuldade em realizar uma generalização científica e para uma necessidade de tempo prolongado para a sua realização. Essas fragilidades segundo esses autores comprometeriam a coleta e a análise dos dados, bem como o próprio resultado da pesquisa.

Yin (2005) salienta que:

O estudo de caso é apenas uma das muitas maneiras de se fazer pesquisa em Ciências Sociais. Experimentos, levantamentos, pesquisas históricas e análise de informações em arquivos (como em estudos de economia) são alguns exemplos de outras maneiras de se realizar pesquisa. Cada estratégia apresenta vantagens e desvantagens próprias, dependendo basicamente de três condições: a) o tipo de questão da pesquisa; b) o controle que o pesquisador possui sobre os eventos comportamentais efetivos; c) o foco em fenômenos históricos, em oposição a 
fenômenos contemporâneos. Em geral, os estudos de caso representam a estratégia preferida quando se colocam questões do tipo 'como' e 'por que', quando o pesquisador tem pouco controle sobre os eventos e quando o foco se encontra em fenômenos contemporâneos inseridos em algum contexto da vida real (...). Independentemente do tipo de estudo de caso, os pesquisadores devem ter muito cuidado ao projetar e realizar estudos de casos a fim de superar as tradicionais críticas que se faz ao método. (YIN, 2001, p. 17).

Sem desconsiderar algumas desvantagens do método do estudo de caso, Yin (2001) destacou que a maior preocupação com esse método talvez seja a falta de rigor metodológico da pesquisa. Essa premissa de alguns autores, segundo ele, por muitas e muitas vezes, ocorreu em função da própria negligência do pesquisador de estudo de caso que não seguiu os procedimentos sistemáticos e permitiu que se aceitassem evidências equivocadas ou visões tendenciosas para influenciar o significado das descobertas e das conclusões. Para superar essa lacuna, Yin (2001) sugeriu que cada pesquisador de estudo de caso redobrasse os seus cuidados tanto no planejamento quanto na coleta e análise dos dados e que o mesmo devesse trabalhar com afinco para expor detalhadamente todas as evidências de forma justa.

No que tange a pouca base para se realizar uma generalização científica, o autor enfatizou que o estudo de caso não representa uma "amostragem" e que o seu propósito é a generalização analítica e não generalização estatística.

Já em relação à necessidade de tempos longos para a realização de estudo de caso, Yin (2001) ressaltou que nas últimas décadas foi possível produzir estudos de caso em períodos mais curtos e com resultados convincentes e testáveis por outras pesquisas.

A escolha do referido município deveu-se à localização geográfica, em função da proximidade com a PUC e com a nossa nova residência, a redução dos custos decorrentes da pesquisa e, sobretudo, pela relevância política, econômica, social e ambiental do município num contexto nacional. Além desses aspectos, a possível facilidade de obter material empírico e documentação e a possibilidade de interlocução com o poder público municipal, com os catadores e as catadoras de materiais recicláveis de quatro cooperativas apoiadas pelo município e com as lideranças do MNCR e do Eu Sou Catador, por intermédio da nossa orientadora foram outros fatores decisivos. 
$\mathrm{Na}$ nossa perspectiva, a alteração do município de Arraial do Cabo para o Rio de Janeiro não consistiria em grande impasse, pois considerávamos que experiência em campo e os dados obtidos com as entrevistas e a pesquisa documental e a bibliográfica em Arraial do Cabo seriam importantes parâmetros, desde que obtivéssemos na nova pesquisa de campo os dados necessários à análise.

A pesquisa no município do Rio de Janeiro iniciou-se em junho de 2017 com uma revisão bibliográfica. Primeiramente, identificamos que não havia a necessidade de mudança e acréscimos de bibliografia em relação ao arcabouço teórico-metodológico. Em seguida, verificamos que as informações do Instituto Brasileiro de Geografia e Estatística - IBGE, do Instituto de Pesquisa Econômica Aplicada - IPEA, do Sistema Nacional de Informações sobre Saneamento - SNIS, da Associação Brasileira de Empresas de Limpeza Pública e Resíduos Especiais ABRELPE, do Compromisso Empresarial para Reciclagem - CEMPRE em parceria com o Instituto de Pesquisas Tecnológicas - ITP, da Confederação Nacional dos Municípios - CNM, do Tribunal de Contas do Estado do Rio de Janeiro, do Tribunal de Contas da União - TCU e da Controladoria Geral da União - CGU a cerca dos resíduos sólidos continuariam exercendo forte influência na reflexão, mesmos alterando o local de pesquisa.

Sendo assim, o levantamento centrou-se na busca de informações sobre o município do Rio de Janeiro, sobre os dados oficiais em relação à gestão e o gerenciamento de resíduos sólidos, bem como aos trabalhos analisando a implantação da política de resíduos sólidos no município. Nesta empreitada obtivemos grande êxito.

Após essa etapa, nos dedicamos à pesquisa sobre a legislação ambiental no campo dos resíduos sólidos, tendo em vista que nesse momento já havíamos efetuado um levantamento sobre a legislação sobre os resíduos em âmbito federal e estadual, em particular sobre a Lei $n^{\circ} 12.305 / 2010$, que estabeleceu a Política Nacional de Resíduos Sólidos, o Decreto n ${ }^{\circ}$ 7.404/10, que regulamentou a Lei e criou o Comitê Interministerial da Política Nacional de Resíduos Sólidos e o Comitê Orientador para a Implantação dos Sistemas de Logística Reversa, o Decreto $\mathrm{n}^{\circ}$ 7.405/2010, que instituiu o Programa Pró-Catador e a Lei $\mathrm{n}^{\circ}$ 4.191/2003, que instituiu a Política Estadual de Resíduos Sólidos. 
Nessa pesquisa em âmbito municipal identificamos como referências para a análise a lei $\mathrm{n}^{\mathrm{o}} 4.969 / 2008$, que definiu os objetivos, instrumentos, princípios e diretrizes para a gestão integrada de resíduos sólidos, com vistas à prevenção e o controle da poluição, a proteção e a recuperação da qualidade do meio ambiente, a inclusão social e a promoção da saúde pública, assegurando o uso adequado dos recursos ambientais no município do Rio de Janeiro, o decreto ${ }^{\circ} 42605$ de 25 de novembro de 2016, que instituiu o Plano Municipal de Gestão Integrada de Resíduos Sólidos - PMGIRS da cidade do Rio de Janeiro e a Lei n ${ }^{\circ} 3.273$, de 06 de setembro de 2001, que dispôs sobre a gestão do sistema de limpeza urbana no município do Rio de Janeiro, assim como a Lei Orgânica e Plano Diretor do Município.

Como desdobramento da pesquisa sobre o arcabouço jurídico relacionado aos resíduos sólidos debruçamo-nos numa pesquisa documental sobre os processos e as sentenças judiciais envolvendo a gestão e o gerenciamento de resíduos no município. Tarefa que se demonstrou complexa e, consequentemente, como primeiro entrave para a pesquisa.

Paralelamente a essa atividade, nos detivemos na busca pela realização das entrevistas com as lideranças do MNCR e do Eu Sou Catador, os catadores e catadoras das quatro cooperativas apoiadas pela prefeitura do Rio de Janeiro e o poder público municipal - COMLURB.

Conseguimos realizar entrevistas com dois dirigentes estaduais do MNCR e com dois dirigentes do Eu Sou Catador, instituições representativas em âmbito nacional. No entanto, não obtivemos êxito, em realizá-las com os catadores e catadoras das cooperativas apoiadas pelo poder público municipal, tendo em vista as sucessivas negativas por parte destes trabalhadores. O mesmo ocorrendo com relação à COMLURB. Nesta instituição conseguimos agendar e realizar duas conversas, uma com um diretor e outra com um técnico da área de resíduos da instituição, nas quais combinamos que retornaríamos as conversas e realizaríamos as entrevistas. Em ambos os casos não conseguimos mais contatos com agentes públicos, embora tenhamos ido por diversas vezes à sede da instituição sem sucesso na empreitada.

Diante desse obstáculo de cunho metodológico, da necessidade do cumprimento dos prazos regimentais para a conclusão do doutorado e consciente dos ensinamentos apontados por Goldenberg (2004), de que a construção de uma 
tese requer além do rigor científico, disciplina e criatividade, um instrumental teórico-metodológico e dados empíricos que permitam ao pesquisador um olhar crítico sobre um determinado problema, decidimos em dezembro de 2018, retornar o lócus da pesquisa para Arraial do Cabo e adotamos como suporte para a descrição, a compreensão e a interpretação da realidade social investigada o estudo de caso no município.

É importante destacar que, nesse momento a nossa dúvida epistemológica sobre a possibilidade de analisarmos uma realidade na qual nós mesmos estávamos inseridos enquanto agentes foi suplantada, muito em função da nova experiência de campo, pela ideia de que por ter o "cordão umbilical" ligado ao lócus da pesquisa, me permitiria o acesso a dados e a dimensões que dificilmente seriam alcançadas por quem "olha de longe".

Em janeiro de 2018 retomamos a pesquisa no município de Arraial Cabo. Nessa época já possuíamos um relevante material bibliográfico e documental, além de três sequências de entrevistas. Mas se fazia necessário revisitar e reavaliar todo o material para verificar a possibilidade de sua utilização, bem como a necessidade de obter novos dados.

O primeiro passo foi revisitar os trabalhos referencias. Iniciamos com os dados do IBGE, que produziu em 2008, a "Pesquisa Nacional de Saneamento Básico" - PNSB 2008 (IBGE, 2010), que investigou 5.564 municípios no Brasil, sendo 1.793 no Nordeste, 1.668 no Sudeste, 1.188 no Sul, 466 no Centro-Oeste e 449 no Norte, levantando informações sobre o saneamento básico com a finalidade de avaliar os serviços de abastecimento de água, esgotamento sanitário, manejo de águas pluviais e manejo de resíduos sólidos prestados à população pelas entidades que atuam no setor, este último de grande importância para análise a ser efetuada nesta pesquisa.

Em relação ao Manejo de Resíduos Sólidos, que é o serviço de saneamento estudado nesta pesquisa, o IBGE (2010) levantou, além dos dados cadastrais das diversas entidades prestadoras do serviço, informações sobre o manejo de resíduos sólidos, a forma de execução e a frequência da coleta domiciliar regular, a varrição e capina, a quantidade dos resíduos sólidos domiciliares e públicos, a disposição no solo dos resíduos sólidos domiciliares e públicos, as unidades de destino dos resíduos sólidos domiciliares e públicos, o manejo de resíduos sólidos especiais e a coleta seletiva. 
Em seguida, retornarmos aos estudos coordenados pelo IPEA no que se refere à política pública de gestão de resíduos sólidos. A primeira foi à pesquisa realizada em 2010, pela Diretoria de Estudos e Políticas Regionais, Urbanas e Ambientais - DIRUR, do IPEA, no âmbito do Acordo de Cooperação Técnica firmado entre o instituto e a Secretaria de Recursos Hídricos e Ambiente Urbano, do Ministério do Meio Ambiente - SRHU/MMA, intitulada "Pesquisa sobre Pagamento por Serviços Ambientais Urbanos para Gestão de Resíduos Sólidos" (IPEA, 2010), que teve como objetivos principais estimar os benefícios econômicos e ambientais gerados pela reciclagem de resíduos sólidos urbanos e propor diretrizes para possíveis esquemas de pagamento por serviços ambientais urbanos provenientes dessa atividade.

A segunda foi à obra intitulada "Diagnóstico dos Resíduos Sólidos Urbanos" (IPEA, 2012), que teve como finalidade construir subsídio ao processo de discussão e elaboração do Plano Nacional de Resíduos Sólidos, conduzido pelo Comitê Interministerial da Política Nacional de Resíduos Sólidos e coordenado pelo Ministério do Meio Ambiente.

A terceira foi "A Situação Social das Catadoras e dos Catadores de Material Reciclável e Reutilizável” (IPEA, 2013), que mostrou que os catadores e as catadoras do Brasil, apesar da heterogeneidade, da diversidade do perfil socioeconômico, do nível de carências e até mesmo do grau de integração social, são trabalhadores submetidos à informalidade, a um alto grau de vulnerabilidade social, a ausência de uma série de direitos trabalhistas, sendo estigmatizados, discriminados, relegados para espaços geográficos marginalizados, mesmo exercendo uma atividade de extrema relevância para a sociedade. A obra retratou também a cadeia da reciclagem, mostrando as suas principais características, a sua importância socioambiental e econômica, a forma como os catadores e as catadoras se inserem na cadeia produtiva da reciclagem, bem como os principais desafios para consolidar os programas de coleta seletiva em âmbito municipal.

A quarta obra foi "Catadores de Materiais Recicláveis: um encontro nacional" (IPEA, 2016) que surgiu como produto do primeiro Encontro Nacional Conhecimento e Tecnologia: inclusão socioeconômica de catadores e catadoras de matérias recicláveis, realizado em Brasília, entre os dias 20 e 22 de agosto de 2014, sob a coordenação da Secretaria Nacional de Economia Solidária, do Ministério do Trabalho e Emprego - SENAES/MTE, do Comitê Interministerial 
para Inclusão Social e Econômica dos Catadores de Materiais Reutilizáveis e Recicláveis - CIISC, da UnB, do Movimento Nacional dos Catadores de Materiais Recicláveis - MNCR e do IPEA. Esse trabalho teve como objetivo atender a uma demanda para construir intercâmbios de saberes, de conhecimentos e de perspectivas sobre as questões relacionadas à reciclagem e, particularmente, sobre os catadores e as catadoras de materiais recicláveis, visando oferecer bases para o amadurecimento das políticas públicas relacionadas à reciclagem, tratando dos entraves e dos avanços desta prática no Brasil. Nele, o IPEA (2016) reuniu 23 artigos versando sobre a questão identitária dos catadores e das catadoras de materiais recicláveis, sobre a organização e fortalecimento coletivo do segmento e sobre o desenvolvimento da tecnologia e da inovação na cadeia produtiva da reciclagem popular.

Retomamos também os dados fornecidos pelo SNIS, que publica anualmente os Diagnósticos da situação da prestação de serviços de saneamento básico, entre eles: o "Diagnóstico dos Serviços de Água e Esgotos", o "Diagnóstico Anual de Águas Pluviais" e o "Diagnóstico do Manejo de Resíduos Sólidos Urbanos” (BRASIL, 2018), este último referencial para a pesquisa.

$\mathrm{Na}$ décima quinta edição do "Diagnóstico do Manejo de Resíduos Sólidos Urbanos", referente aos dados do ano de 2016 participaram da coleta de dados 3.670 municípios, do total de 5.570, ou seja, 65,9\% municípios, o que correspondeu a 165.762.351 milhões de habitantes, e em termos de população urbana correspondeu ao percentual de 80,4\%, respondendo por 146,3 milhões de habitantes urbanos. É importante destacar que a população urbana estimada pelo SNIS, em cada município brasileiro, baseou-se na estimativa da população total medida pelo IBGE, multiplicada pela taxa de urbanização do censo de 2010.

As informações contidas no "Diagnóstico do Manejo de Resíduos Sólidos Urbanos", referente ao ano de 2016, foram fornecidas por órgãos gestores dos serviços nos municípios, que, por sua vez, para receberem os recursos do Ministério das Cidades têm que apresentar anualmente, desde 2009, o Atestado de Regularidade de Fornecimento de Dados ao SNIS. O SNIS manteve a integridade das respostas dadas pelos municípios. Contudo, na presença de informações e indicadores classificados como inconsistentes, o relatório, objetivando estabelecer confiança, realizou expurgos de valores julgados excessivamente altos ou baixos. 
Retomamos ainda o trabalho da ABRELPE sobre "Panorama dos Resíduos Sólidos no Brasil", do CEMPRE intitulado "Lixo Municipal: Manual de Gerenciamento Integrado" (CEMPRE, 1995), no qual abordou o gerenciamento integrado do lixo municipal, a origem e composição do lixo, os serviços de limpeza e a disposição final do lixo, objetivando contribuir com informações para o gerenciamento dos resíduos municipais e para a implantação de políticas públicas para se estabelecer as melhores formas de destinação e de disposição finais de resíduos, e do CNM intitulados a "Política Nacional de Resíduos Sólidos: obrigações dos Entes federados, setor empresarial setor e sociedade" (CNM, 2015a) e o "Estudo Técnico - Gestão Municipal de Resíduos Sólidos" (CNM, 2015b).

Finalizamos a revisão bibliográfica com os trabalhos desenvolvidos pelo TCU e pelo CGU. O primeiro referente a um levantamento, realizado pelo TCU, por meio da Secretaria de Controle Externo da Agricultura e do Meio Ambiente (SecexAmbiental), sobre a forma de institucionalização e normatização da Política Nacional de Resíduos Sólidos - PNRS (BRASIL, 2016a), regulamentada pelo Decreto $\mathrm{n}^{\mathrm{o}}$ 7.404/10 (BRASIL, 2010) como importante instrumento ambiental para a gestão integrada e o correto gerenciamento de resíduos sólidos. Já o segundo foi um trabalho de auditoria desenvolvido pelo CGU para avaliação da atuação do Governo Federal no cumprimento da meta de eliminação dos lixões e consequente disposição ambientalmente adequada dos resíduos (BRASIL, 2016b), conforme previsto na Lei $\mathrm{n}^{\mathrm{o}}$ 12.305/2010.

No mês de março, nos debruçamos sobre a pesquisa documental tomando como norte o mesmo procedimento da revisão bibliográfica. Ou seja, revendo o material que já possuíamos e identificando a necessidade de novos documentos. Neste processo travamos contato com dois novos documentos fundamentais à análise.

O primeiro foi uma Auditoria Governamental na Prefeitura de Arraial do Cabo (RIO DE JANEIRO, 2013), no âmbito do tema Resíduos Sólidos, realizado pelo TCE/RJ para verificar as condições de organização e funcionamento dos serviços de limpeza urbana e manejo dos resíduos sólidos, conforme definido no Plano Anual de Auditoria Governamental PAAG 2013 (Processo TCE/RJ n ${ }^{\circ}$ 303.761-3/12), no que tange ao planejamento e organização, coleta de resíduos urbanos e de serviço de saúde, e sua destinação final. 
O segundo uma Ação Civil Pública $n^{\circ}$ 0000412-67.2007.8.19.0005, promovida pelo Ministério Público do Estado do Rio de Janeiro, por meio da Promotoria de Justiça de Tutela Coletiva, Núcleo Cabo Frio, em face do Município de Arraial do Cabo, da Empresa Cabista de Desenvolvimento Urbano e Turismo - ECATUR e da empresa Emmanuel Teixeira Pontes Serviços.

Essa Ação Civil Pública em defesa da ordem urbanística, da saúde pública e do meio ambiente, com requerimentos de antecipação dos efeitos da tutela final que determinou aos réus a elaboração do Programa Municipal de Gerenciamento de Resíduos Sólidos, de um Cronograma de Medidas de controle e adequação ambiental para a operação da Usina de Reciclagem e Compostagem e do vazadouro de resíduos, bem como de um projeto de recuperação da qualidade ambiental da área destinada ao funcionamento da Usina de Reciclagem e Compostagem e do vazadouro de resíduos sólidos foi estrutural na pesquisa, pois além de mostrar os principais sujeitos sociais envolvidos ilustrou a forma como a política de resíduos sólidos foi desenvolvida no município ao longo dos últimos 30 anos, evidenciando as fragilidades, os riscos, os desafios e as possibilidades para sua implantação, sobretudo no que concerne a inclusão dos catadores e das catadoras de materiais recicláveis na gestão dos resíduos.

Em relação às entrevistas semiestruturadas com os principais atores sociais responsáveis pela gestão dos resíduos, a saber: os dirigentes e catadores e catadoras da Cooperativa de Coleta e Reciclagem da Costa do Sol e o poder público, representado pela Secretaria Municipal de Ambiente e pela Fundação Municipal de Meio Ambiente, Pesquisa, Ciência e Tecnologia não foi diferente.

No ano de 2009, havíamos entrevistado 29 (vinte e nove) catadores e catadoras de materiais recicláveis, que atuavam na Usina de Reciclagem e no lixão de Arraial do Cabo. Estas entrevistas não tiveram nenhuma relação com a pesquisa de doutorado, apenas servindo para contribuir com a produção de um diagnóstico sobre a política municipal de resíduos, especialmente para identificar o sistema de limpeza urbana, a estrutura e o modelo operacional de manejo, a destinação e a disposição final dos resíduos e as reais condições da Usina de Reciclagem e dos catadores e das catadoras de materiais recicláveis.

Essas entrevistas não foram realizadas com a finalidade de subsidiar a pesquisa, entretanto, consistiram em importantes fontes de informações, principalmente por fornecer uma perspectiva histórica da visão dos sujeitos 
sociais no que concerne o período anterior à aprovação da Política Nacional de Resíduos Sólidos e da reforma e ampliação da Usina de Reciclagem.

A segunda fase das entrevistas ocorreu em setembro de 2012, quando o município cumpriu as exigências da FUNASA e tornou-se apto a receber os recursos do convênio 0848/2009. Nesse período, entrevistamos os mesmos 29 (vinte e nove) catadores e catadoras de materiais recicláveis da Cooperativa de Coleta e Reciclagem da Costa do Sol. As entrevistas versaram sobre os dados pessoais e profissionais dos catadores e catadoras de materiais recicláveis, sobre as condições socioeconômicas dos trabalhadores após a formação da cooperativa, sobre as condições de trabalho e salubridade e, principalmente, sobre como deveria ser a reforma e ampliação da Usina de Reciclagem. É importante ressaltar que, essas entrevistas também não se vincularam aos interesses acadêmicos, mas à implantação de uma política pública. Contudo, as mesmas foram de extrema relevância para a pesquisa.

Em 2014, realizamos a terceira fase de entrevistas com 8 (oito) catadores e catadoras de materiais recicláveis, todavia com o interesse de oferecer respostas aos questionamentos levantados na pesquisa do doutorado. Os modelos das entrevistas encontram-se no Apêndice 1 (Termo de esclarecimento livre e consentido) e nos Apêndices 2, 3 e 4 (Roteiro de entrevistas).

Nessa época ainda éramos gestor público e estávamos intimamente vinculados ao processo de reforma e ampliação da Usina de Reciclagem de Arraial do Cabo, tendo em vista que a instituição que presidíamos apesar de não possuir atribuição de gestão, foi a responsável pela elaboração do projeto aprovado, via concurso público, na Fundação Nacional de Saúde - FUNASA.

Essa condição de gestor somada à realização da obra foi fundamental no sentido de facilitar obtenção de dados por parte dos catadores e das catadoras da Cooperativa de Coleta e Reciclagem da Costa do Sol e pelos outros agentes públicos. Além disso, muitos deles (as) se sentiam motivados e dispostos a responder aos nossos questionamentos, em função da posição política que ocupávamos. Entretanto, inibia alguns desses trabalhadores (as) de realizarem comentários negativos em relação à política de resíduos adotada pelo poder público municipal.

Como já havíamos conseguido nas entrevistas anteriores os dados pessoais e profissionais dos catadores e catadoras, bem como um conjunto de dados sobre a 
formação e atuação da cooperativa, entre elas quando a cooperativa de catadores de materiais recicláveis foi fundada, como era divisão de tarefas na cooperativa, como funcionava o sistema de partilha da cooperativa, como era definido o preço dos materiais recicláveis e qual era a jornada de trabalho dos cooperativados, nos dedicamos nessas entrevistas a obter informações sobre quais os principais problemas enfrentados pelos catadores e catadoras e, principalmente, se a PNRS estava proporcionando a sua inclusão social.

Já em relação ao poder público municipal as entrevistas foram relacionadas a existência ou não do Plano Municipal de Resíduos Sólidos, se a PNRS estava propiciando no município uma destinação final adequada dos resíduos com a meta de eliminação e recuperação do lixão e se já havia a coleta seletiva com inclusão social e a emancipação econômica dos catadores e das catadoras de materiais recicláveis.

Essas entrevistas derem base para a análise do objeto, entretanto consideramos relevante retomá-las para balizar ainda mais a pesquisa. Desse modo, no início de novembro de 2018, quando já não fazíamos mais parte da estrutura da administração municipal retomamos o processo de entrevistas no município.

Entrevistamos novamente 8 (oito) catadores e catadoras da Cooperativa de Coleta e Reciclagem da Costa do Sol e um ex-dirigente do MNCR. Vale destacar, entretanto, que não obtivemos êxito nas entrevistas com os gestores públicos locais. Desse modo, repetimos as entrevistas com antigos gestores públicos.

Em relação às entrevistas fazem-se indispensáveis algumas considerações. Primeiramente que as entrevistas semiestruturadas foram introduzidas como mais um instrumento metodológico fundamental porque, como afirmou Triviños (1987), ao mesmo tempo em que valoriza a presença do investigador oferece todas as perspectivas possíveis para que o informante alcance a liberdade e a espontaneidade necessárias, enriquecendo a investigação. Além disso, favorece a descrição e explicação dos fenômenos sociais, bem como a compreensão de sua totalidade.

No caso específico da pesquisa, foi um instrumento relevante para obter informações sobre a realidade dos atores sociais em seus próprios contextos, sobre as fragilidades, contradições, limites e possibilidades da implantação da Política 
de Resíduos Sólidos no município, em particular no que se refere à participação e inclusão dos catadores e catadoras no processo de gestão.

Em segundo, que a realização das entrevistas em momentos distintos foi importante no sentido de perceber os pontos de vista dos sujeitos ao longo dos últimos 09 (nove) anos, bem como para verificar possíveis mudanças de postura e de posicionamentos diante da política municipal de resíduos sólidos.

Evidentemente que, na busca por responder se a Política de Resíduos Sólidos no município do Arraial do Cabo contribui para ampliar a justiça ambiental em relação aos catadores e as catadoras, estivemos atentos às diferentes posições e respostas diante dos cenários surgidos, buscando estabelecer uma articulação dos dados da pesquisa com os nossos pressupostos e arcabouço teórico-metodológico.

Para tanto, como sugeriu Minayo (1992) nossa atenção foi redobrada para superar as armadilhas e obstáculos próprios da análise de dados, em particular a ilusão da obviedade desses que conduzem o pesquisador às conclusões superficiais ou equivocadas, à preocupação excessiva com os métodos e às técnicas, desconsiderando os significados dos dados e a dificuldade em articular as conclusões que surgem dos dados concretos com conhecimentos amplos.

\subsection{Estrutura da Tese}

No que tange à estrutura da tese, além da introdução, teremos mais três capítulos e as considerações finais.

No segundo capítulo intitulado "A história do pensamento ambientalista e seus rebatimentos políticos na atualidade" ressaltamos que foi a partir do lançamento das bombas atômicas nas cidades de Hiroshima e Nagasaki e, principalmente, com a publicação do livro "A Primavera Silenciosa”, de Rachel Carson, que a sociedade moderna, seu modelo de desenvolvimento, sua ciência e tecnologia passaram a ser questionadas. Entretanto, coadunamos com o historiador marxista Hobsbawm (1995) quando afirmou que no contexto de Guerra Fria e do boom desenvolvimentista da "Era de Ouro", em função da ideologia hegemônica da fé no crescimento e no progresso, a destruição ambiental não estava no centro da agenda política, só passando a ser tratada com mais 
sistematicidade quando a "Era de Ouro" começou a dar sinais de crise, com o reaparecimento nos países industrializados do desemprego em massa, da pobreza, da miséria e da instabilidade econômica.

Ressaltamos o papel do Clube de Roma e do relatório "Limites do Crescimento" (1987), da Conferência de Estocolmo, do Relatório "Nosso Futuro Comum", da Conferência Rio 92 e da Conferência Rio+20, dentre outras para colocar a discussão ambiental no centro do debate político, da agenda pública e para o surgimento de políticas ambientais.

Enfatizamos nesse processo histórico os paradigmas dominantes voltados à resolução da "crise ambiental". Primeiramente, o paradigma do Crescimento Zero consubstanciado no relatório "Limites do Crescimento", no qual afirmava que a sociedade industrial precisava modificar o seu modelo de desenvolvimento, sob o risco de colapso generalizado e o paradigma do Desenvolvimento Sustentável, que propõe a compatibilização entre crescimento econômico, justiça social e a preservação ambiental.

Posteriormente, problematizamos o paradigma do desenvolvimento sustentável, proposto pelo Relatório de Brundtland e consolidado pela Conferência Rio 92, indagando sobre a sua efetividade, alcance, contradições e limitações para o enfrentamento da chamada "crise ambiental" e para nortear políticas públicas, especialmente à política de resíduos sólidos no Brasil.

$\mathrm{Na}$ nossa visão, a impossibilidade dessa conciliação decorre da perspectiva acrítica ao modelo de desenvolvimento e de sua base civilizacional e também por desconsiderar a existência dos atores sociais responsáveis pela degradação ambiental, omitindo a conjuntura histórica, os conflitos e as contradições do modo de produção capitalista e sua essência predatória.

Por essa razão enfatizamos que em nossa análise sobre a Política de Resíduos Sólidos no município do Arraial do Cabo utilizaremos como arcabouço teórico a ecologia política e a justiça ambiental, articulando a reflexão teórica e à experiência prática das lutas sociais, com a problemática ambiental e as consequentes ameaças à saúde coletiva e à vida de populações vulnerabilizadas.

No terceiro capítulo intitulado "A Política Nacional de Resíduos Sólidos no Brasil: fragilidades, contradições, limites e possibilidades" fizemos uma revisão bibliográfica sobre os trabalhos abordando as questões referentes aos resíduos 
sólidos e as políticas voltadas à gestão e ao gerenciamento dos resíduos mais precisamente sobre a Política Nacional de Resíduos Sólidos no Brasil.

Nessa perspectiva, evidenciamos que a humanidade sempre produziu os resíduos como parte de sua própria existência e que as sociedades desenvolveram estratégias para afastá-los para onde não criassem problemas para as atividades comunitárias, mas destacamos que foi a partir da segunda metade do século XIX, com o processo de urbanização e industrialização, que a concepção sobre a saúde pública e a atenção aos resíduos começou a ser alterada.

Mostramos o surgimento e a evolução da preocupação com o saneamento na cidade do Rio de Janeiro, em particular com o esgotamento sanitário, a limpeza urbana, o manejo e a disposição final de resíduos sólidos, apontando para os seus obstáculos, limites e avanços.

Na sequência do capítulo, enfatizamos que no período Pós Segunda Guerra, com os avanços tecnológicos e com os novos padrões de consumo, as preocupações sobre resíduos sólidos ganharam força na Europa, mas ainda centrada na disposição final, sem grandes questionamentos do processo produtivo, o que perdurou até a Conferência de Estocolmo, em 1972, quando as questões ambientais ascenderam à agenda contemporânea. Esse cenário de aumento vertiginoso dos impactos ambientais estimulou o reexame dos problemas relacionados aos fenômenos das externalidades, incorporando dentro da análise econômica a variável ambiental, alterando assim, o modelo de gestão de resíduos sólidos centrado na disposição final, inserindo a reciclagem dos materiais, a incineração com reaproveitamento de energia e a disposição de resíduos em aterros sanitários como novas prioridades na política de gestão de resíduos em nível internacional.

Destacamos que na década de 1980 a prioridade na gestão dos resíduos passou a ser a redução do seu volume no início do processo produtivo, tendo os fabricantes à responsabilidade pelo seu tratamento e disposição final. Foi nesse contexto, que ocorreram as experiências inovadoras na gestão dos resíduos sólidos, que articularam práticas governamentais com organizações de catadores e de catadoras de materiais recicláveis. Entretanto, ressaltamos que o manejo ambientalmente saudável dos resíduos tornou-se uma das questões mais relevantes para a manutenção da qualidade do meio ambiente da Terra e para 
alcançar um desenvolvimento ambientalmente saudável em todos os países, a partir da Conferência Rio 92.

Apresentamos o processo histórico de construção da Política Nacional de Resíduos Sólidos, enfatizando os principais sujeitos sociais envolvidos no debate e as suas posições, assim como o processo de resistência para a aprovação do Projeto de Lei sobre os resíduos sólidos, em particular por parte dos empresários por se posicionarem contra a responsabilidade pós-consumo, na qual os fabricantes de produtos e embalagens deveriam ser responsáveis pelo ciclo integral daquilo que colocassem no mercado, recolhendo os produtos e embalagens após o uso pelo consumidor, dando para esses uma destinação ambientalmente correta.

Apresentamos as principais vertentes analíticas sobre os resíduos sólidos nos anos 2000, em particular as que ressaltaram as táticas de resistência adotadas pelos catadores e as catadoras de materiais recicláveis diante de um processo perverso de filiação e as que relacionavam a questão dos resíduos sólidos à saúde pública e à construção de políticas públicas que contemplassem diferentes dimensões do problema, como inclusão social, preservação ambiental, saúde pública e o resgate da dignidade desses trabalhadores, bem como algumas análises sobre a Política Nacional de Resíduos Sólidos no Brasil, instituída em 2010, abordando, principalmente, o papel dos catadores e das catadoras no processo de gestão e as dificuldades encontradas por esse segmento para que a lei $\mathrm{n}^{\circ} \mathbf{1 2 . 3 0 5 / 1 0}$ fosse cumprida.

Concluímos o terceiro capítulo mostrando que, após oito anos de promulgação da Política Nacional de Resíduos Sólidos, obtivemos avanços socioambientais, entretanto, há um conjunto de riscos e fragilidades a serem superadas para plena aplicação da lei.

Para demonstrar essa hipótese tomamos como fio condutor de análise o estudo de caso sobre a política de gestão de resíduos no município de Arraial do Cabo.

No quarto capítulo, denominado "O Município de Arraial do Cabo e a Política Nacional de Resíduos Sólidos”, iniciamos com a contextualização do município, apresentando suas características geográficas, históricas, socioeconômicas e ambientais. Em seguida, fizemos um resgate histórico em relação à limpeza urbana, ao manejo, à destinação e à disposição final dos 
resíduos no município, a partir da análise bibliográfica e documental e de entrevistas com diversos sujeitos sociais envolvidos no processo de gestão de resíduos em Arraial do Cabo.

Esse resgate mostrou-se de grande relevância por dar ênfase aos olhares dos sujeitos sociais envolvidos com esta política e por contribuir para a construção da memória social sobre a gestão e o gerenciamento dos resíduos no município. Além desse aspecto, ele revelou-se de grande importância no sentido de permitir visualizar o panorama dos resíduos sólidos no município antes e depois da promulgação da Política Nacional de Resíduos Sólidos.

Dando continuidade à reflexão, apresentamos alguns avanços no campo socioambiental em Arraial do Cabo com a aprovação da Política Nacional dos Resíduos Sólidos.

Finalizamos o capítulo apresentando os desafios para implantação da política local de resíduos sólidos, explicitando o processo de vulnerabilidades e de inclusão precária aos quais os catadores e as catadoras do município estão submetidos, bem como os limites e possibilidades no processo de gestão dos resíduos no município de Arraial do Cabo, principalmente para incorporar a sustentabilidade social como um norte para evitar o processo de vulnerabilidade e de injustiça ambiental. 


\section{A história do pensamento ambientalista e seus rebatimentos políticos na atualidade}

Ciente da necessidade de contextualizar o tema analisado no interior de um debate teórico existente, esta pesquisa não utilizará a perspectiva do desenvolvimento sustentável, entendido aqui nos termos exposto pelo Relatório Brundtland como um processo de transformação na qual a exploração dos recursos naturais, a direção do investimento, a orientação do desenvolvimento tecnológico e a mudança institucional se harmonizam e reforçam o potencial presente e futuro, ou como aquele que "atende às necessidades do presente sem comprometer a capacidade de as gerações futuras também atenderem às suas". (Relatório Brundtland, 1991, p. 34).

Tal opção teórica e metodológica ocorreu em função de considerarmos o conceito dúbio, impreciso e limitado em seu conteúdo, portanto com baixa efetividade, alcance e capacidade como mecanismo para o enfrentamento da chamada "crise ambiental" e para nortear políticas públicas inclusivas a serem adotadas pelos diversos governos, em particular à política de resíduos sólidos no Brasil.

O conceito de desenvolvimento sustentável parte do pressuposto que é possível à conciliação entre a preservação ambiental e o crescimento econômico, entretanto, não considera necessária a reorganização da base civilizacional, nem a reestruturação política, econômica, social, cultural e ambiental da sociedade.

Esta ótica eco-capitalista ou do "capitalismo esverdeado", coloca como razões da degradação ambiental o crescimento populacional, a pobreza e o uso de tecnologias poluidoras e propõe como solução o controle populacional, a utilização de tecnologias limpas e a ajuda financeira dos países ricos aos pobres para reduzir a pobreza.

A perspectiva do desenvolvimento sustentável não explicita as raízes estruturais da pobreza, nem evidencia os mecanismos pelas quais a pobreza tem sido socialmente construída nas últimas décadas no nível internacional, ou seja, não a evidencia como produto histórico de modelo de desenvolvimento concentrador de poder, renda e de distribuição desigual dos danos ambientais. Além de negligenciar que a riqueza é causadora da degradação ambiental e a maior a produtora dejetos. 
Não questiona também o modelo de crescimento vigente, ao contrário coloca-o como caminho para superação da pobreza e da "crise ambiental", sem sequer fazer menção ao próprio espírito devastador que permeia as relações insustentáveis de produção e consumo.

Concordamos com Silva (2010), quando argumentou que o desenvolvimento sustentável ao incorporar a pobreza como parte estruturante de sua formulação, seja como causalidade ou como obstáculo à preservação ambiental sem considerar a dinâmica de acumulação do capital, não vincula a degradação da natureza e a desigualdade social como partes constituintes da dinâmica de acumulação capitalista, apartando a sustentabilidade ambiental da social.

É evidente que o crescimento populacional tem um impacto significativo sobre a natureza, pois quanto mais pessoas no mundo, maior será a pressão sobre os recursos naturais, entretanto não é o crescimento populacional um dos grandes vilões da "crise ambiental", mas sim à lógica produtivista, consumista e excludente, centrada na expansão do mercado e do lucro e não na satisfação das necessidades humanas.

A ótica do desenvolvimento sustentável não coloca limites à atuação do mercado e acredita que o crescimento econômico pode continuar indefinidamente no mesmo ritmo, desde que ocorram modificações tecnológicas. Desse modo, ao invés de inserir uma racionalidade ambiental e repensar o modelo econômico e tecnológico da sociedade industrial, se permanece centrado numa racionalidade econômica e instrumental do sistema capitalista hegemônico.

Não se trata como destacou Lipietz (2002) de rejeição da noção de progresso nem de mergulhar em um "catastrofismo" antitécnico, mas de se dar o lugar certo ao progresso técnico, uma vez que não há razão para considerá-lo "naturalmente" dotado de virtudes.

O desenvolvimento sustentável parte da premissa básica de que a humanidade possui preocupações e desafios comuns sem considerar a existência de atores sociais responsáveis pela degradação ambiental, omitindo dessa forma, como destacou Layrargues (1997), o contexto histórico, os conflitos e as contradições, cuja consequência significa a retirada do componente ideológico da questão ambiental, que passa a ser considerada com certa dose de ingenuidade e 
descompromisso, frente à falta de visibilidade do procedimento histórico que gerou a "crise ambiental".

Segundo Foladori (2001), o desenvolvimento sustentável incorporou à conservação da natureza externa (sustentabilidade ecológica), a sustentabilidade social e a sustentabilidade econômica. No entanto, as instituições e práticas de política ambiental continuam considerando exclusivamente a sustentabilidade ambiental, privilegiando dessa forma a perspectiva tecnicista, ideologicamente comprometida com o capitalismo.

Para o autor, as ações visando à busca pela equidade social, eficiência econômica e preservação ambiental são limitadas porque partem de uma ótica acrítica ao modelo de produção hegemônico, que aposta na chamada "modernização ecológica", na ecoeficiência, e na ética produtivista e consumista do capitalismo.

Além disso, como apontou Leff (2006), essa perspectiva não vislumbrou substituir a racionalidade econômica e produtivista insustentável da modernidade por uma racionalidade ambiental, visando à construção de um futuro sustentável, fundado na satisfação das necessidades básicas, nos potenciais da natureza, na criatividade cultural, num pensamento emancipatório focado na participação e em uma ética política para renovar o sentido e a sustentabilidade da vida.

No que tange a problemática dos resíduos, a perspectiva do desenvolvimento sustentável, como ressaltou Layrargues (1997), a vê como uma questão de ordem técnica, psicológica e comportamental. Desse modo, para resolver essa problemática não se faz necessário à ruptura com o modelo de desenvolvimento insustentável, sendo preciso apenas inovações tecnológicas, políticas, institucionais e mudanças comportamentais.

Em contraponto ao ideário do desenvolvimento sustentável, na nossa reflexão tomaremos como aporte teórico metodológico à investigação a ecologia política, que segundo Carneiro (2005) busca aproximar e articular a reflexão teórica e a análise crítica do capitalismo à experiência prática das lutas sociais que, nas atuais condições de mundialização do sistema produtor de mercadorias, põem em jogo a apropriação social das condições naturais e a distribuição dos riscos e degradações ambientais.

$\mathrm{Na}$ apreciação da implantação da Política de Resíduos Sólidos no município do Arraial do Cabo, a ecologia política servirá como bússola para investigar se há 
efetivamente uma gestão integrada, que inclua democraticamente os catadores e as catadoras de materiais recicláveis no processo de gestão, ou se essa política ambiental se constitui de forma discriminatória, guiada por uma lógica sociopolítica promotora da desigualdade ambiental, impondo malefícios aos trabalhadores, que apesar de executam um papel central na cadeia produtiva da reciclagem, transformando os resíduos em mercadoria, são destituídos de poder financeiro e político.

Reforçando o campo de análise, empregaremos como princípio a justiça ambiental que, segundo Herculano (2002), é uma linha de pesquisa e de ação no campo do Ambientalismo e da Sociologia Ambiental que busca analisar, pela perspectiva das desigualdades de classe, a problemática da poluição ambiental e das consequentes ameaças à saúde coletiva de populações vulnerabilizadas.

De acordo com a autora, essa perspectiva propõe outro modelo de desenvolvimento e de padrão sociopolítico que não venha sobrecarregar de malefícios à saúde e o bem estar das populações com baixo poder de se fazer ouvir pelo Estado.

Para Acselrad et. al. (2009), a noção de justiça ambiental exprime um movimento de ressignificação da questão ambiental que resulta de uma apropriação singular da temática do meio ambiente por dinâmicas sociopolíticas tradicionalmente envolvidas com a construção da justiça social.

A justiça ambiental nega peremptoriamente a razão utilitária hegemônica, que vê o meio ambiente composto estritamente de recursos materiais, sem conteúdos socioculturais específicos e que o risco ambiental é único e a poluição global e democrática, não sendo propensa a fazer distinções de classe.

Nega também o ideário da modernização ecológica e a sua estratégia para conciliar o crescimento econômico com a resolução dos problemas ambientais, dando ênfase à adaptação tecnológica, à celebração da economia de mercado, ao progresso técnico, ao consenso político e a recusa a regulações políticas e a lógica dos direitos.

Para Acselrad et al. (2009) na ótica da justiça ambiental o debate ecológico deve questionar o conteúdo do modo de desenvolvimento, o que se produz, como se produz e para quem se produz. Em outros termos, é preciso questionar se o modelo de desenvolvimento produz para a acumulação e benefícios de poucos ou 
para a justiça social, além de interrogar sobre os fins pelos quais os homens se apropriam dos recursos do planeta.

Eles argumentam ainda que, nessa perspectiva, o meio ambiente é múltiplo em qualidades socioculturais, não havendo ambiente sem sujeito e que os riscos ambientais são diferenciados e desigualmente distribuídos, dado a diversificada capacidade de os grupos sociais escaparem aos efeitos.

De acordo com Acselrad et al. (2009) para a superação desse quadro de injustiça social e ambiental seria necessária a alteração do modo de distribuição desigual de poder sobre os recursos ambientais e a retirada da capacidade dos poderosos de transferir os custos ambientais do desenvolvimento para os mais despossuídos.

$\mathrm{Na}$ análise do nosso objeto de pesquisa, essa perspectiva será de extrema utilidade no sentido investigar se há uma distribuição desigual dos danos ambientais e processos de vulnerabilidades na implantação da política de resíduos sólidos do município de Arraial do Cabo sobre os catadores e as catadoras de materiais recicláveis, o elo mais frágil da cadeia produtiva da reciclagem.

Para tanto, identificaremos se há equidade na aplicação da política de resíduos sólidos, se há uma regulação efetiva sobre dos agentes econômicos causadores dos riscos ambientais e se há uma democratização dos processos decisórios com plena participação dos catadores e catadoras de materiais recicláveis no processo de gestão e gerenciamento dos resíduos.

Mas antes vamos conhecer como surgiu e se institucionalizou o desenvolvimento sustentável, enquanto mecanismo de enfrentamento da problemática ambiental ditado pelas agências internacionais.

\subsection{O Pós-Segunda Guerra Mundial e a Eclosão do Ambientalismo}

No século XX, o pensamento ambientalista, como apontou Herculano (1992) após o início dos testes nucleares e com o lançamento das bombas atômicas pelos Estados Unidos da América nas cidades de Hiroshima e Nagasaki no Japão, reacendeu como uma crítica à sociedade moderna, seu modelo de desenvolvimento, sua ciência e tecnologia.

Conforme destacou Oliveira (2011), as explosões das bombas atômicas em terras nipônicas significaram a retomada do medo do fim do mundo pelo uso da 
ciência e da tecnologia com interesses destrutivos, pois o homem que se tornara "senhor e possuidor da natureza" ameaçava a sua própria sobrevivência, em escala planetária, em função das disputas por riqueza e poder.

Além disso, este acontecimento emblemático deixou claro que a ameaça era real às gerações presentes e futuras, tendo em vista o potencial destrutivo dos armamentos nucleares.

Tomando de empréstimo a noção de "ordem do medo", de Milton Santos (2000), Oliveira (2011) destacou ainda que essa noção, aliada à ideia de catástrofes, será fundamental para reflexões sobre as questões ambientais e o início de movimentos pacifistas e antinucleares que, posteriormente, viriam a se consolidar nos primeiros movimentos ambientalistas na década de 1960.

Hobsbawm (1995) observou que após o fim da Segunda Guerra Mundial a humanidade conheceu a Guerra Fria, um evento marcado pela constante ameaça de um conflito nuclear e por uma corrida armamentista entre as superpotências emergentes, a União das Repúblicas Socialistas Soviéticas (URSS) e os Estados Unidos da América (EUA), que permaneceu razoavelmente estável até meados da década de 1970, quando o sistema internacional e a unidade que o compunham entraram num período de extensa crise política e econômica.

Para Hobsbawm (1995) a Guerra Fria, apesar de disseminar a ideia de uma batalha nuclear global que poderia eclodir a qualquer momento e devastar a humanidade, foi um acordo de coexistência de poder entre as duas superpotências acomodadas com as conquistas adquiridas com o fim da Segunda Guerra Mundial:

A peculiaridade da Guerra Fria era a de que, em termos objetivos, não existia perigo iminente de guerra mundial. Mais que isso: apesar da retórica apocalíptica de ambos os lados, mas, sobretudo, do lado americano, os governos das duas superpotências aceitaram a distribuição global de forças no fim da Segunda Guerra Mundial, que equivalia a um equilíbrio de poder desigual, mas não contestado em sua essência. A URSS controlava uma parte do globo, ou sobre ela exercia predominante influência - a zona ocupada pelo Exército Vermelho e/ou outras Forças Armadas comunistas no término da guerra - e não tentava ampliá-la com o uso da força militar. Os EUA exerciam controle e predominância sobre o resto do mundo capitalista, além do hemisfério norte e oceanos, assumindo o que restava da velha hegemonia imperial das antigas potências coloniais. Em troca, não intervinha na zona aceita de hegemonia soviética. (Hobsbawn,1995, p.179). 
De acordo com Hobsbawm (1995), apesar da possibilidade do confronto nuclear e da corrida armamentista serem os aspectos de maior obviedade da Guerra Fria, a sua maior consequência foi a polarização política do mundo em dois blocos: os pró-comunistas e os capitalistas.

Nessa intensa guerra política, econômica, ideológica e diplomática, travada pela conquista de zonas de influência, os Estados Unidos da América, analisando equivocadamente a experiência soviética de crescimento econômico e com medo desse modelo ser seguido pelas nações em desenvolvimento, implantaram, em 1947, o Plano Marshall, uma política econômica direcionada à reconstrução material dos países capitalistas destruídos na Segunda Guerra Mundial, objetivando fortalecer o capitalismo e a sua hegemonia, parar a "ameaça" soviética e modernizar as sociedades consideradas "atrasadas".

O projeto desenvolvimentista americano foi exitoso porque possibilitou a recuperação econômica de grande parte dos países beneficiados, reduzindo consequentemente o desemprego e pobreza nos países industrializados e permitindo aos Estados Unidos aumentarem as exportações para a Europa Ocidental e expandir a sua influência política sobre a região.

Em contrapartida, a União Soviética, temendo avanço do capitalismo e ingerência econômica e política por parte dos Estados Unidos no bloco socialista da Europa Oriental criou, em janeiro de 1949, o Conselho para Assistência Econômica Mútua - COMECON, destinada a promover a cooperação e a coordenação econômica entre os países socialistas e a discutir políticas de desenvolvimento para os países membros e seus aliados.

O apoio Soviético via COMECON permitiu aos países da Europa Oriental alinhados com a União Soviética uma expansão econômica, com ênfase na indústria, na mecanização dos campos e no Estado como indutor da economia e da sociedade.

Nesse contexto de boom econômico que, de acordo com Herculano (1992), a ideia do desenvolvimento surgiu no início da década de 1960 como arma dos Estados Unidos para a construção da sua hegemonia na nova ordem mundial.

Dando continuidade ao projeto desenvolvimentista, os Estados Unidos promoveram um processo de difusão da modernização, por meio da qual as sociedades ditas atrasadas, numa linha evolucionista, rumariam para o desenvolvimento, tendo a sociedade americana como o norte. 
Desse modo, sairiam da condição de economia de subsistência, baseadas no setor agrícola, com baixos índices educacionais e com altas taxas de natalidade e mortalidade, para economias modernas, calcadas no predomínio industrial, com tecnologia avançadas e altos níveis educacionais e baixo crescimento vegetativo.

Nessa ótica, o desenvolvimento era sinônimo de industrialização, inovação técnica, crescimento econômico, expansão das forças produtivas, uma "sociedade internacional aberta" com cooperação internacional, tendo como paradigma de sociedade desenvolvida a norte-americana.

Na contramão dessa perspectiva, segundo Herculano (1992), se posicionou a Comissão Econômica para a América Latina - CEPAL, criada pelas Nações Unidas em 1948, com a finalidade de estudar o subdesenvolvimento latinoamericano, procurando explicar raízes e possibilidades de sua superação.

Essa escola de pensamento acreditava que o desenvolvimento endógeno, promovido por uma industrialização autônoma evitaria os problemas econômicos latinoamericanos derivados de trocas desiguais entre países exportadores de matérias-primas e outros, exportadores de manufaturados.

Para Furtado, um renomado economista brasileiro da "Teoria da Dependência" (1998), a despeito do caráter predatório do processo civilizatório, a ideia de desenvolvimento foi utilizada como um "mito" para mobilizar os povos da periferia a aceitar os sacrifícios da dependência e legitimar a destruição de suas culturas.

Herculano (1992) afirmou que no final da década de 1960 as teorias desenvolvimentistas receberam críticas radicais de marxistas, enfatizando que o "subdesenvolvimento" dessas sociedades ditas arcaicas era um produto histórico, no qual o sistema internacional capitalista, composto por países centrais, drenava para si as riquezas produzidas por países periféricos, de capitalismo dependente.

Hobsbawm (1995) argumentou que no cenário da Guerra Fria e da "Era de Ouro" ou “Anos Dourados” (1945-1973), a despeito de a poluição e a degradação ecológica parecerem ameaçadores, não chamou tanta atenção a não ser de entusiastas da vida silvestre e protetores de raridades humanas e naturais, tendo em vista que a ideologia hegemônica do desenvolvimento e do progresso tinha como certo que o domínio da natureza pelo homem era a medida do avanço da humanidade. 
Concordamos com a análise de Hobsbawm quando afirmou que na "Era de Ouro" a preocupação central era sobre desenvolvimento e subdesenvolvimento, e que a degradação ambiental não estava no centro da agenda das políticas públicas. Entretanto, já a partir do início dos anos 1960, como afirmou McCormick (1992), há o surgimento de um novo movimento baseado nas preocupações com o estado do ambiente humano e com as atitudes humanas em relação à natureza, em particular a superpopulação e a poluição decorrente da tecnologia e do crescimento econômico.

Ressaltamos neste contexto a publicação, em outubro de 1962, do livro "A Primavera Silenciosa", da autora americana Rachel Carson, descrevendo em detalhes os impactos negativos do uso dos agrotóxicos e dos pesticidas, os limites do progresso tecnológico, a necessidade de respeitar o ecossistema para proteger a saúde humana e o meio ambiente e as consequências inesperadas e indesejadas da ciência moderna.

Apesar de ter sido negada e rebatida pelos grandes industriais e por cientistas da época, por a considerarem sem precisão científica, a tese paradigmática da autora foi posteriormente aceita, servindo como uma alerta para a humanidade sobre os níveis de degradação ambiental impetrado pelo modelo de desenvolvimento hegemônico, colocando à vista algumas das infraestruturas sociais, econômicas e científicas que permitiram a ocorrência de degradação ecológica.

Além destes aspectos, "A Primavera Silenciosa" contribuiu para o aumento da consciência pública quanto às implicações e os custos da atividade humana sobre o meio ambiente e para a criação de um conjunto de leis sobre proteção ambiental.

Baseado em McCormick (1992), destacamos que os grandes acidentes ambientais que ocorreram a partir dos meados dos anos 1960 também tiveram impacto significativo para o aumento da sensibilidade pública para os problemas ambientais e, por conseguinte, para eclodir o movimento ambientalista 5 .

Ainda de acordo McCormick (1992), apesar de possuírem bandeiras distintas os movimentos por direitos civis, o operário, o feminista, o estudantil e o hippie e sua contracultura, com um caráter pacifista, antinuclear e antiprogressista,

\footnotetext{
${ }^{5}$ Entre os principais desastres destacamos: o desmoronamento, em outubro de 1966, de uma pilha de resíduos de mina acima do povoado de Aberfan, no sul do País de Gales, o qual resultou na morte de cento e quarenta e quatro pessoas, 116 das quais crianças da escola local, os variados derramamentos de petróleo, especialmente Torrey Canyon em março de 1967, na qual cerca de 117 mil toneladas de petróleo cru se espalharam perto da costa do extremo sudoeste da Inglaterra, mostrando os custos econômicos da poluição e os desdobramentos do desastre de Minamata, no Japão, no qual pescadores e moradores foram contaminados por mercúrio.
} 
contrários ao Estado industrial totalitário, belicista, produtivista e consumista também foram fundamentais para eclosão do movimento ambientalista.

Quando a "Era de Ouro" começou a dar sinais de esgotamento da prosperidade econômica, do pleno emprego, dos altos salários e da política do Bem Estar Social, com o reaparecimento nos países industrializados do desemprego em massa, da pobreza, da miséria e da instabilidade, bem como do questionamento do papel do Estado enquanto propulsor do desenvolvimento, a problemática ambiental começou a ganhar contornos de uma preocupação geral, entrando no centro do debate político de diversos segmentos da sociedade mundial e da agenda pública.

\subsection{O Relatório "Limites do Crescimento" e as polêmicas do Crescimento Zero}

Para Herculano (1992), nesse processo, o Clube de Roma, uma associação fundada em 1968 pelo industrial italiano e presidente do Comitê Econômico da Organização do Tratado do Atlântico Norte - OTAN, Aurelio Peccei, reuniu representantes da indústria, economistas, cientistas, líderes políticos, de governo e de instituições financeiras com o objetivo repensar, via perspectiva industrial hegemônica, a conjuntura mundial e debater um conjunto de ideias e de ações relacionadas à economia, à política, ao desenvolvimento e ao meio ambiente tendo extrema relevância.

Como apontou McCormick (1992), a meta definida pelo Clube de Roma foi incentivar a compreensão dos componentes econômicos, políticos, naturais e sociais interdependentes do "sistema global", e encorajar a adoção de novas atitudes, políticas e instituições capazes de atenuar a degradação ambiental, a expansão urbana, a perda de fé nas instituições, nos valores tradicionais e na economia.

Com esse propósito, afirmou o autor, o Clube de Roma, por meio de uma equipe do Massachusetts Institute of Technology (MIT), uma universidade privada de pesquisa localizada em Cambridge, no estado de Massachusetts, nos Estados Unidos, concluiu em 1972 uma análise que foi substanciada no relatório "Limites do Crescimento".

O relatório afirmava que a sociedade industrial precisava modificar e ajustar o seu modelo de desenvolvimento, com altas taxas de crescimento demográfico, de industrialização, de poluição, de produção de alimentos e de exploração de 
recursos, e que era possível alterar as tendências de crescimento e atingir um estado de estabilidade econômica e ecológica que fosse sustentável por muito tempo no futuro, garantindo o equilíbrio global de forma planejada, de modo a suprir as necessidades materiais básicas de cada pessoa na terra.

Para tanto, utilizou-se de conceitos matemáticos e de princípios neomalthusianos, em particular, a ideia de que o crescimento demográfico e a pressão exercida por este sobre os recursos naturais seria o elemento central a ser enfrentado pela sociedade para evitar a degradação da qualidade de vida.

Como proposta de ação, o relatório apontou para a necessidade de controlar o aumento demográfico, congelar o crescimento global e o capital industrial, ou seja, para a tese do Crescimento Zero para todos os países, alegando que se os padrões de crescimento continuassem sem alterações os limites planetários seriam ultrapassados, ocasionando uma catástrofe ambiental.

$\mathrm{Na}$ perspectiva de Celso Furtado (1998), a grande contribuição do Relatório "Limites do Crescimento" foi trazer a problemática ambiental para a agenda política mundial, colocando-a no centro do debate sobre o desenvolvimento econômico, tema até então negligenciado e deixado a "sombra" pelos economistas.

De acordo com Dias (2000), apesar de alcançar o objetivo de alertar à humanidade para a necessidade de maior prudência na utilização dos recursos naturais, as propostas estabelecidas pelo Clube de Roma receberam diversas críticas, sendo uma delas merecedora de destaque: a consciência ecológica dos "poderosos" era uma manobra com intuito de desarmar o debate ecológico de seu caráter anticapitalista e conter as discussões nos limites do sistema do capital.

Segundo McCormick (1992), a crítica mais aguda ao relatório "Limites do Crescimento" foi desenvolvida na Grã-Bretanha por pesquisadores ligados à Unidade de Pesquisa de Ciência Política da Universidade de Sussex, apontando as fragilidades metodológicas da análise do documento e dos valores ideológicos de seus criadores.

McCormick (1992) destacou que para esses pesquisadores, havia erros nos argumentos desenvolvidos, em particular uma carência de dados e que a perspectiva subestimou o progresso técnico, não considerou que os limites do crescimento eram mais políticos e sociais do que físicos e que havia um limite na abordagem da dinâmica de sistemas. 
Destacou ainda que alguns autores, entre eles, Robert Solow, consideravam as previsões do Clube de Roma demasiadamente pessimista e catastrofistas, tendo em vista desconsiderarem os avanços da tecnologia, que poderiam evitar a exaustão dos recursos naturais.

Para Herculano (1992) a proposta do relatório "Limites do Crescimento" do Clube de Roma de Crescimento Zero foi um importante orientador dos debates internacionais pré-Conferência de Estocolmo, porém contra ela se rebelou a bancada dos 77 países componentes do chamado Terceiro Mundo, arguindo que os países desenvolvidos só pensaram em preservar a natureza após a destruírem e que propor para os países em desenvolvimento zerar o crescimento econômico era uma injustiça. Esse debate permaneceu e tornou-se central na Conferência de Estocolmo.

Para Silva (2010), o Relatório do Clube de Roma, diante do embate sobre a impossibilidade de um crescimento ilimitado num sistema que necessitava de recursos naturais finitos, apresentou o controle de natalidade como alternativa para enfrentar os problemas socioeconômicos. Essa proposta, de acordo com a autora, não pôs em xeque o modelo de desenvolvimento, mas deslocou a problemática colocando o crescimento populacional como responsável pela pobreza e a destruição ambiental.

Entendemos que, apesar de conservador, o relatório "Limites do Crescimento", com sua proposta de Crescimento Zero colocou a questão ambiental no centro da agenda política, enfatizando as graves consequências do uso irracional e indiscriminado dos recursos naturais e, além disso, possibilitou um aumento na produção acadêmica da questão ambiental. Contudo, identificamos algumas limitações nessa proposta.

Em primeiro lugar, não concordamos com o argumento de que seria possível um Crescimento Zero dentro dos marcos do capitalismo, pois essa proposta contraria a natureza e os próprios fundamentos desse sistema.

Em segundo, a proposta de Crescimento Zero negligenciou a persistente colonialidade que afeta a natureza latinoamericana, tanto na realidade biofísica como sua configuração territorial, que articula significativamente os ecossistemas e o pensamento hegemônico global e das elites dominantes da região como um espaço subalterno, que pode ser explorado, arrasado, reconfigurado, segundo as necessidades do regime de acumulação vigente. 
Em terceiro, não sinalizou para a distribuição da riqueza produzida entre as nações, dessa forma mantendo a desigualdade e o status quo vigorante. Além disso, o relatório sequer falou da dependência dos países desenvolvidos dos recursos naturais dos países do chamado Terceiro Mundo para manter a reprodução do capital.

Por fim e não menos importante, essa perspectiva focou-se mais no crescimento demográfico e na pobreza como causas principais dos efeitos catastróficos sobre a natureza, não problematizando o modelo de desenvolvimento capitalista e a sua lógica predatória.

\subsection{Da Conferência de Estocolmo à Rio+20: do desenvolvimentismo ao Desenvolvimento Sustentável}

Realizada no período de 05 a 16 de junho de 1972, na Suécia, a Conferência das Nações Unidas sobre o Meio Ambiente Humano, conhecida também como Conferência de Estocolmo, foi, de acordo com Herculano (1992), a primeira grande reunião organizada de maneira global a dedicar-se às questões ambientais.

Como sinalizou Oliveira (2011), a Conferência de Estocolmo ocorreu em um momento de profundas turbulências na ordem geopolítica mundial proveniente da crise do fordismo, da Guerra do Vietnã, do crescimento de movimentos populares e do início da segunda crise do petróleo, que eclodiria em 1973.

McCormick (1992) afirmou que a Conferência de Estocolmo foi sem dúvida um marco fundamental no crescimento do ambientalismo internacional. Para ele, foi a primeira vez que os problemas políticos, sociais e econômicos do meio ambiente global foram discutidos num fórum intergovernamental com uma expectativa de empreender ações corretivas e fazer convergir à atenção dos governos e da opinião pública em vários países para a importância da degradação ambiental.

Para Le Prestre (2005), a Conferência de Estocolmo foi motivada pelo aumento da cooperação científica na década de 1960, resultante da identificação das mudanças climáticas e da ameaça à qualidade das águas para o consumo, pela publicidade, em decorrência dos desastres ambientais, pelo crescimento econômico acelerado, gerador de profunda alteração na sociedade e de seus 
modos de vida e pelos inúmeros problemas identificados no final da referida década pelos cientistas e o governo sueco.

Constituído como um importante marco histórico, político e jurídico, a Conferência de Estocolmo, segundo Herculano (1992), foi palco de uma profunda controvérsia marcada pela retórica e pelo dissenso de dois grupos antagônicos.

De um lado os países desenvolvidos do eixo Norte, que defendiam a diminuição imediata do ritmo de crescimento e, de outro, os países em desenvolvimento do Sul, que se recusavam a assumir os compromissos propostos porque limitariam a sua capacidade de crescimento e de garantir os níveis adequados de qualidade de vida às suas populações, além deste ponto embora não negligenciassem os efeitos da degradação ambiental não se viam como sujeitos sociais responsáveis por eles.

Para os países em desenvolvimento, a alegação dos países desenvolvidos para conter o desenvolvimento econômico e os efeitos danosos causados pelo desenvolvimento industrial, científico e tecnológico, em particular a veloz e destrutiva utilização das riquezas naturais não passava de uma "cortina de fumaça" para limitar os seus programas de industrialização, usando a justificativa da poluição como um meio de inibir a capacidade de competição dos países em desenvolvimento e para manter a sua dependência econômica e tecnológica e, consequentemente, o status quo.

McCormick (1992) citou dois exemplos nessa direção. O primeiro, do embaixador Keith Johnson, da Jamaica, relator geral da conferência, que destacou que vários países em desenvolvimento se sentiam receosos de que a Conferência de Estocolmo fosse mais uma estratégia dos países desenvolvidos para evitar o seu desenvolvimento e crescimento econômico.

O segundo exemplo ressaltado pelo autor foi o do chefe da delegação chinesa, Tang Ke, que num discurso apoiou os países em desenvolvimento, alegando que cada país teria o direito de definir os seus padrões de crescimento e as suas políticas ambientais e que nenhum país poderia prejudicar os interesses dos países em via de desenvolvimento sob o pretexto de proteger o meio ambiente.

Na Conferência de Estocolmo, a tese do Crescimento Zero também sofreu críticas dos segmentos sociais e ambientalistas por acreditarem que essa tese culpabilizava a pobreza pela degradação ambiental, sem considerar a dinâmica do 
capitalismo, além de não dar conta da totalidade social e não vincular a degradação da natureza e a desigualdade social como partes constituintes da acumulação capitalista.

Edward Goldsmith, representante dessa corrente, publicou em 1972, o "Manifesto pela Sobrevivência", na qual partindo de uma perspectiva marxiana, direcionava uma crítica voraz ao modelo industrial capitalista, o apontando como o responsável pela degradação ambiental, sendo, portanto, necessária à ruptura com o modelo de desenvolvimento, sob o risco de colapso.

Para ele, a luta ecológica esbarrava nas leis que governam o sistema capitalista, ou seja, a acumulação crescente do capital, a mais-valia, o trabalho alienado, o desperdício, a exploração e a miséria. Assim, para superar a crise ambiental não bastaria ações anticonsumistas de caráter individual, mas seria imperiosa a ruptura com capitalismo e o seu modo de produção e consumo.

O que se verifica é que na Conferência de Estocolmo há uma quebra de paradigma no que tange à chamada "crise ambiental", tendo em vista que se rompeu com a ideia de desenvolvimento zero e se propôs a compatibilização entre desenvolvimento econômico e a preservação ambiental, o que mais tarde culminaria na noção de desenvolvimento sustentável.

McCormick (1992), ilustrando essa ruptura resaltou que, Maurice Strong, o Secretário Geral da Conferência de Estocolmo, negou o conceito de Crescimento Zero como uma política viável para as sociedades, alegando que seria necessário repensar os conceitos de crescimento para surgir "um novo movimento de libertação" para emancipar os seres humanos dos perigos ambientais criados por eles mesmos.

Mesmo diante de grande controvérsia entre os países desenvolvidos e os em desenvolvimento, foi criada a Declaração de Estocolmo, assinada pelos países participantes, com 109 recomendações para a cooperação internacional, descrevendo as responsabilidades, os critérios e os princípios norteadores das políticas no campo ambiental.

Conforme destacou Herculano (1992), os resultados pós Conferência de Estocolmo não foram os esperados. Contudo houve progresso, como a criação do Programa das Nações Unidas para o Meio Ambiente (PNUMA), a primeira agência ambiental global, do Programa Observação Terra, que monitora as variadas formas de poluição e da criação da Comissão Mundial para o Meio Ambiente e Desenvolvimento (CMMAD). 
Coadunando com Layrargues (1997), acreditamos que a Conferência de Estocolmo, objetivando atender os interesses dos países do Norte de ocultar os impactos do sistema capitalista, em particular a poluição da riqueza e dos países do Sul no sentido de conseguir recursos financeiros para mitigar a pobreza, conciliou interesses antagônicos.

A Conferência de Estocolmo consolidou a questão ambiental na agenda política, além trazer avanços no âmbito da sociedade civil, no campo jurídico com a elaboração de leis e órgãos ambientais em diversos países do mundo e na esfera institucional e diplomática com a criação de novas conferências para tratar da problemática ambiental.

Entretanto, nela, o foco original do ambientalismo contestatório que relacionava a "crise ambiental" ao modelo de organização social e aos meios de produção da ideologia dominante foi paulatinamente sendo substituído por um enfoque voltado para a questão do desenvolvimento econômico e para medidas objetivando conter o destrutivo ritmo de utilização das riquezas naturais, ou seja, para a construção de uma base conceitual pautada na composição desenvolvimento e sustentabilidade, com a finalidade de compatibilizar o crescimento capitalista com a temática ambiental, sem colocar em xeque o sistema produtivo e de consumo.

Como desdobramentos dos debates ocorridos no Clube de Roma e na Conferência de Estocolmo, Maurice Strong, em 1973, lançou as bases do conceito de ecodesenvolvimento, estabelecido como proposta para um novo modelo de desenvolvimento, um novo projeto civilizacional.

Nessa proposta seria possível imaginar um caminho de desenvolvimento que fosse justo socialmente, ecologicamente prudente e eficiente economicamente. Para tanto, seria necessário uma perspectiva holística e sistêmica voltada para o entendimento da interdependência dos aspectos econômicos, políticos, culturais, sociais e ambientais.

Além desse ponto, seria crucial abandonar a perspectiva antropocêntrica, que considerava o meio ambiente como um simples meio de produção e gerador de riqueza e o reducionismo economicista baseado exclusivamente no cálculo econômico, na qual as políticas de desenvolvimento reduzem-se a meras ações que visam o crescimento da economia. 
O conceito de ecodesenvolvimento foi apropriado por Sachs na década de 1980 e definido como um desenvolvimento endógeno e dependente de suas próprias forças, tendo por objetivo responder à problemática da harmonização dos objetivos sociais e econômicos do desenvolvimento com uma gestão ecologicamente prudente dos recursos do meio.

Essa nova perspectiva integrou na problemática do desenvolvimento, centrada na eficiência econômica, a justiça social e a prudência ecológica. Nesta ordem, o ecodesenvolvimento apresentou uma inovação ética no sentido de que o desenvolvimento econômico deveria estar conectado ao atendimento das necessidades sociais e ao cuidado com a preservação ambiental, garantindo para as gerações atuais e futuras possibilidades de se desenvolver.

O ecodesenvolvimento proposto por Sachs (1986) critica as soluções universalizantes, porque apesar de ser importante considerar outras experiências as sociedades humanas são capazes de identificar os seus problemas e as suas soluções, isto é, de buscar uma resposta de caráter endógeno de acordo com suas próprias potencialidades.

A crítica do ecodesenvolvimento também foi direcionada ao excessivo otimismo tecnológico, segundo a qual a sociedade sempre encontrará uma solução, via progresso técnico, aos problemas econômicos, sociais ou ecológicos.

Sachs promoveu ainda uma crítica contundente à atuação sem controle do mercado. Para ele, a atuação desse tem que possuir uma regulação estatal, pois a sua ação ilimitada, com ênfase em sistemas técnicos complexos conduzirá para um mau desenvolvimento. Sendo assim, para alcançar um desenvolvimento comprometido com a sustentabilidade ecológica e a justiça social, se faz determinante impor um teto do consumo material, procurando valorizar esferas não materiais da vida.

Para tornar o conceito operacional, haveria a necessidade do amplo conhecimento e respeito das culturas e dos ecossistemas, o envolvimento dos cidadãos no planejamento das estratégias, devido ao conhecimento da realidade local, ao pluralismo tecnológico e à elaboração de um sistema social garantindo emprego, segurança social e educação.

Sachs (1986) estabeleceu cinco dimensões de sustentabilidade do ecodesenvolvimento, a saber: a sustentabilidade econômica, a social, a ecológica, a cultural e a espacial. 
A sustentabilidade econômica centra-se na eficácia econômica, com uma alocação e uma gestão mais eficiente e regular dos recursos e investimentos públicos e privados. Essa eficiência econômica deverá ser medida em critérios macrossociais e não somente pela rentabilidade de caráter microeconômico.

A sustentabilidade social foca-se na necessidade de redução das diferenças sociais, portanto das desigualdades e da pobreza. A sustentabilidade ecológica liga-se ao uso dos potenciais inerentes dos ecossistemas de forma conectada a preservação e ao mínimo de deterioração dos recursos naturais, enquanto base da biodiversidade. A sustentabilidade cultural refere-se ao respeito pelas especificidades de cada ecossistema, de cada cultura e de cada local. A sustentabilidade espacial relaciona-se a uma configuração rural e urbana de maneira mais equilibrada, evitando concentração de poder, atividade e população.

Como veremos posteriormente, a proposta de ecodesenvolvimento apresentada por Sachs, centrada na ideia de que o modelo de desenvolvimento deve necessariamente levar em conta a preservação ambiental, a justiça social, desembocou para muitos autores no conceito de desenvolvimento sustentável do Relatório "Nosso Futuro Comum", também conhecido mundialmente como "Relatório Brundtland".

Em 1983, a médica especializada em saúde pública, Gro Harlem Brundtland foi convidada para presidir a Comissão Mundial sobre o Meio Ambiente e Desenvolvimento, promovida pela Organização das Nações Unidas (ONU) para fazer uma avaliação dos 10 anos da Conferência de Estocolmo e produzir um resultado formal sobre a situação econômica e da degradação ambiental no mundo.

Como desdobramento das várias reuniões e audiências da Comissão Mundial, foi produzido, em 1987, o "Relatório Brundtland", evidenciando o desafio global de conter as ameaças ao equilíbrio ambiental, em particular o aumento da pobreza e populacional, o efeito estufa, o crescimento da produção dos resíduos, o desflorestamento, a erosão do solo, a desertificação e a contaminação dos recursos hídricos.

Para reverter o quadro, o "Relatório Brundtland" afirmou em seu prefácio ser imperioso "uma agenda global para a mudança" com estratégias ambientais de longo prazo para obter um desenvolvimento sustentável por volta do ano 2000 e, posteriormente, a esse período recomendar maneiras para que a preocupação 
como meio ambiente se traduza em maior cooperação entre os países em desenvolvimento e entre os países em estágios diferentes de desenvolvimento econômico e social e que leve à consecução de objetivos comuns interligados e que considerem a inter-relação de pessoas, recursos, meio ambiente e desenvolvimento.

O Relatório Brundtland, estruturado em 3 partes, sendo a primeira referente às preocupações comuns, a segunda sobre os desafios comuns e a terceira abordando os esforços comuns para alcançar uma sociedade sustentável, afirmou haver a necessidade imperiosa de repensar o modelo de desenvolvimento, tendo em vista que se tal mudança não acontecesse à humanidade colocaria em risco a sua própria sobrevivência.

Assim, segundo o relatório, repensar e implantar um modelo de desenvolvimento, por meio de crescimento econômico, apoiado em práticas que conservassem e expandissem a base dos recursos ambientais e contribuísse para a redução da pobreza seria fundamental para construir um futuro próspero, mais justo e mais seguro.

Para tanto, o relatório afirmou ser necessária uma ação política voltada à administração dos recursos do meio ambiente no intuito de assegurar o progresso humano e sobrevivência da humanidade.

Assim, começou a se estruturar e criar raízes uma perspectiva ideológica de conciliação da preservação ambiental e do crescimento econômico, mantendo-se o modelo de desenvolvimento dentro dos marcos do capitalismo, de modo a legitimar o status quo.

Segundo o Relatório Brundtland, a pobreza foi identificada como uma das principais causas e um dos principais efeitos dos problemas ambientais no mundo.

A pobreza não é apenas um mal em si mesma, mas para haver um desenvolvimento sustentável é preciso atender às necessidades básicas de todos e dar a todos a oportunidade de realizar suas aspirações de uma vida melhor. Um mundo onde a pobreza é endêmica estará sempre sujeito a catástrofes ecológicas ou de outra natureza. (COMISSÃO MUNDIAL SOBRE MEIO AMBIENTE E DESENVOLVIMENTO, 1991, p.16).

O crescimento populacional, sobretudo nos países pobres foi apontado no Relatório Brundtland como outra importante causa da degradação ambiental. 
Assim, segundo o relatório, estabelecer políticas para a redução populacional seria fundamental para obter progresso em vários campos, pois em muitas partes do mundo, a população vinha aumentando a taxas incompatíveis com os recursos ambientais disponíveis, frustrando qualquer expectativa razoável de obter progressos em áreas como habitação, serviços sanitários, segurança alimentar ou fornecimento de energia.

O Relatório Brundtland apontou ainda o uso de tecnologias poluidoras como mais uma causa da degradação ambiental, assim para solucioná-la seria necessária à substituição dessas por tecnologias limpas ecologicamente adaptadas.

No referido relatório foi reconhecida a finitude dos recursos naturais e da necessidade de cooperação internacional para orientar as políticas e ações no sentido de fazer as mudanças necessárias para alcançar uma sociedade sustentável. Reconheceu ainda que modelo de desenvolvimento era insustentável, sendo ele o culpado pelo progressivo empobrecimento de parte da população mundial, entretanto apresentou como solução a continuidade e ampliação do crescimento mundial combinado com a proteção ambiental.

Mas seria possível alcançar essas metas no marco do capitalismo? O Relatório de Brundtand concluiu que sim, por meio do desenvolvimento sustentável.

O que seria o desenvolvimento sustentável segundo o relatório?

Como falado anteriormente, o Relatório Brundtland definiu o desenvolvimento sustentável como um processo de transformação na qual a exploração dos recursos naturais, direção do investimento, a orientação do desenvolvimento tecnológico e a mudança institucional se harmonizam e reforçam o potencial presente e futuro, a fim de atender às necessidades $\mathrm{e}$ aspirações futuras. Mas como alcançá-lo?

Para o Relatório Brundtland seria necessário que todos os países modificassem as suas políticas e adotassem imperativos estratégicos para promover a harmonia entre os seres humanos e entre a humanidade e a natureza.

Para tanto, se fazia indispensável adotar:

Um sistema político que assegure a participação no processo decisório, um sistema econômico capaz de gerar excedentes e know-how técnico em bases confiáveis e constantes, um sistema social que resolva as tensões causadas pelo desenvolvimento desequilibrado, um sistema de produção que respeite a 
obrigação de preservar a base ecológica do desenvolvimento, um sistema tecnológico que busque constantemente novas soluções, um sistema internacional que estimule padrões sustentáveis de comércio e financiamento e um sistema administrativo flexível e capaz de auto corrigir-se. (COMISSÃO MUNDIAL SOBRE MEIO AMBIENTE E DESENVOLVIMENTO, 1991, p. 46).

Assim, seria possível a retomada do crescimento, a alteração da qualidade do desenvolvimento, o atendimento as necessidades de emprego, alimentação, energia, água e saneamento, a manutenção do crescimento populacional em níveis sustentáveis, a conservação e melhoria da base de recursos, a reorientação da tecnologia e a administração dos riscos e a inclusão do meio ambiente e a economia no processo de tomada de decisões, ou seja, o desenvolvimento sustentável.

Como vimos, há grandes convergências entre os conceitos de ecodesenvolvimento e do e desenvolvimento sustentável, mas será que por partirem de pressupostos comuns os conceitos significam a mesma coisa?

Será que esses conceitos utilizam as mesmas estratégias para alcançar o objetivo de uma sociedade economicamente viável, socialmente justa e ecologicamente sustentável? Será que esses conceitos, apesar de apresentarem princípios e metas em comum, representam o mesmo projeto político e ideológico?

Tomando como referência os trabalhos de Acselrad "Desenvolvimento sustentável: a luta por um conceito" e de Leroy "Modelo de desenvolvimento: mudança real ou adaptação", Layrargues (1997) questionou a tese de que ocorreu uma evolução conceitual do ecodesenvolvimento para o desenvolvimento sustentável, e que, portanto, não poderiam ser consideradas e utilizadas como sinônimos.

Segundo Layrargues (1997), uma análise mais atenta e contextualizada entre os princípios do ecodesenvolvimento e do desenvolvimento sustentável mostraria as diferenças teóricas e ideológicas, esclarecendo a falácia dessa afirmativa.

$\mathrm{O}$ autor apontou para as semelhanças entre o ecodesenvolvimento e o desenvolvimento sustentável, entre elas destacou: a visão holística, a solidariedade com as gerações futuras como um princípio ético, a noção de que componente ambiental deve entrar juntamente com o critério econômico no processo decisório, a preocupação com a justiça social e a perspectiva de que a 
dimensão ambiental deve ser intrinsecamente ligada ao processo de desenvolvimento.

Entretanto, Layrargues (1997) ressaltou existir diferenças que traduzem ideologias distintas, tendo em vista que entre as metas propostas e os meios utilizados pelo desenvolvimento sustentável, há profundos traços de incompatibilidades.

Em primeiro lugar, afirmou o autor, o desenvolvimento sustentável acredita no mercado total como caminho para a resolução da "crise ambiental". Já o ecodesenvolvimento propõe limites ao mercado. Em segundo, apresenta como caminho para a justiça social o aumento do consumo médio per capita. Todavia aumentar o consumo significa aumentar as externalidades ambientais. Em terceiro, enquanto o ecodesenvolvimento reforça o perigo da crença ilimitada na tecnologia e propõem tecnologias endógenas, o desenvolvimento sustentável acredita que a partir das inovações tecnológicas será possível aos povos chegarem à fartura, sem comprometimento da sustentabilidade ambiental. Por fim, o autor ressaltou que a concepção do ecodesenvolvimento possui compromisso com a autonomia dos povos e países menos favorecidos na ordem internacional e com a redução das desigualdades sociais, o que não se verifica no desenvolvimento sustentável.

Além desses pontos, Layrargues (1997) enfatizou que o discurso ideológico acentua a erradicação da pobreza como a tônica do desenvolvimento sustentável, omitindo o peso da responsabilidade da poluição da riqueza.

Diante do exposto por Layrargues (1997), argumentamos que os conceitos ecodesenvolvimento e desenvolvimento sustentável não possuem o mesmo projeto político e ideológico emancipador, pois apesar de apoiar-se em princípios do ecodesenvolvimento como a articulação entre crescimento econômico, justiça social e preservação ambiental, o desenvolvimento sustentável assumiu a condição de um projeto ecológico neoliberal despolitizante, com destaque na economia e no avanço tecnológico, que produziu a ilusão de mudanças, mas que se manteve dentro dos marcos da ideologia hegemônica.

Reforçamos a nossa conclusão nos apoiando em Leff (2006) que afirmou:

As próprias estratégias de resistência à mudança da ordem econômica foram dissolvendo o potencial crítico e transformador das práticas de Ecodesenvolvimento. Daí surge a busca de um conceito capaz de ecologizar a 
economia, eliminando a contradição entre crescimento econômico e preservação da natureza (...). Começa então naquele momento a cair em desuso o discurso do Ecodesenvolvimento, suplantado pelo discurso de Desenvolvimento Sustentável (LEFF, 2006, p. 18).

Ribeiro (1992) afirmou que com a crise do capitalismo e com a hegemonia do pensamento neoliberal dos anos de 1980, o desenvolvimento sustentável surgiu como parte de estratégia global de reestruturação sistêmica, isto é, uma hábil operação político, normativa e diplomática empenhada em sanar um conjunto de contradições expostas e não respondidas pelos modelos anteriores de desenvolvimento, na qual o principal interesse é gerenciar os efeitos da degradação ambiental provenientes da reprodução econômica do capitalismo.

Afirmamos que o Relatório de Brundtland trouxe para o discurso público e para a arena política o conceito de desenvolvimento sustentável, apresentando-o como uma nova era, na qual a justiça ambiental, o crescimento econômico e a preservação ambiental caminharão juntos. Entretanto, não passa de uma nova roupagem, alinhando os interesses econômicos capitalistas com a questão ambiental, com a manutenção de políticas desenvolvimentistas, com a retomada do crescimento econômico, aliada a mudanças comportamentais como forma de solucionar a "crise ecológica".

Coadunamos com Layrargues (1997) ao afirmar que as ações propostas pela Comissão Brundtland, visando a busca pela equidade social, eficiência econômica e preservação ambiental, são limitadas porque partem de uma ótica acrítica ao modelo de produção hegemônico e sua ética consumista, portanto sua essência predatória que aposta na chamada modernização ecológica.

Nesse novo discurso ideológico sobre a "crise ambiental", a ideia central de crítica ao capitalismo, ao industrialismo, ao produtivismo, ao consumismo e a dominação foi substituída por um discurso salvacionista, na qual todos são vítimas e também responsáveis de forma igualitária pela "catástrofe ecológica". Portanto, não se propõe mais um modelo alternativo de desenvolvimento.

Essa perspectiva será aceita e aprofundada na Conferência Rio 92, conforme veremos a seguir.

Albuquerque (2008) argumentou que desde a Conferência de Estocolmo em 1972, estava prevista a realização de uma segunda conferência para discutir a temática ambiental, sendo a proposta apresentada no relatório "Nosso Futuro 
Comum" da Comissão Brundtland, que culminou na aprovação da Resolução 44/228 da Assembleia Geral das Nações Unidas, realizada em dezembro de 1989, convocando a mesma para o ano de 1992.

De acordo com ele, a fase preparatória da Conferência iniciada em 1990 foi composta por quatro encontros com objetivo de elaborar um programa de ações, para tratar de diretrizes, medidas e ações relacionadas à mudança de clima, biodiversidade e floresta e estabelecer mecanismos de acompanhamento do progresso e da implantação dos resultados.

Entretanto, o estabelecimento de acordos de ordem política para que não se repetisse a falta de ação de Estocolmo foi rechaçada, principalmente pelos Estados Unidos e Reino Unido, contrários a assumir compromissos para a mobilização de recursos financeiros novos e a fundo-perdido, para os países em desenvolvimento.

A Conferência das Nações Unidas sobre o Meio Ambiente e o Desenvolvimento (CNUMAD), também conhecida como Cimeira da Terra, Rio92 ou Eco 92 foi realizada no período de 03 a 14 de junho de 1992, no Rio de Janeiro.

Para Candotti (2011) a Conferência Rio 92 possuía como objetivos levar à consideração das políticas de comércio e indústria dos países participantes um programa de redução dos impactos sociais e ambientais causados pelo sistema produtivo, responder à pressão dos movimentos sociais preocupados com a crescente devastação dos recursos e ambientes naturais, promover o debate de novos modelos de desenvolvimento econômico atentos à justiça social, à conservação dos ecossistemas e aos limites da exploração das matérias-primas e estabelecer convenções e tratados internacionais dedicados à preservação das condições de sobrevivência das espécies que habitam o planeta e o equilíbrio dos ecossistemas complexos.

Além desses objetivos, o autor afirmou que pretendia definir códigos e normas que orientassem programas de conservação ambiental, e limitassem os danos provocados pela ação do homem sobre a terra, a água e o ar, promover a cooperação internacional em projetos de recuperação e proteção dos ambientes físicos e naturais, aproximar o debate dos temas ecológicos e as políticas ambientais às grandes questões do desenvolvimento econômico, da pobreza, da saúde, da educação, das concentrações urbanas e do crescimento populacional e 
associar às iniciativas de proteção à biodiversidade e à valorização da sociodiversidade.

Sob forte influência do Relatório Brundtland, ela reuniu delegações de 178 países e 114 Chefes de Estado ou Governo, entre eles: Fidel Castro, George Bush e François Miterrand, com a finalidade de consolidar uma agenda global com estratégias de celebrar as diretrizes dominantes sobre a questão ambiental.

Nessa Conferência, segundo Oliveira (2011), ocorreram dois eventos paralelos: o Fórum Global, no Aterro do Flamengo envolvendo as ONGs, os movimentos sociais, os mais diversos líderes religiosos, intelectuais, artistas, movimentos populares, poetas, filósofos, jornalistas, entre outros segmentos sociais e a Cúpula da Terra, realizada no Riocentro com a reunião das delegações oficiais dos países participantes, na qual a diplomacia fazia os acordos internacionais. Vale ressaltar que somente a Cúpula da Terra possuía caráter deliberativo, portanto institucionalmente tendo um peso decisório.

Na Cúpula da Terra produziu-se a Declaração do Rio sobre Meio Ambiente e Desenvolvimento, a Convenção sobre Mudanças Climáticas, a Convenção sobre Diversidade Biológica, a Declaração sobre Princípios para um Consenso Global sobre Manejo, Conservação e Desenvolvimento Sustentável de Todos os Tipos de Florestas e a Agenda 21 e no Fórum Global foi elaborada a Declaração da Terra.

O Fórum Global produziu um documento democrático e participativo que estabeleceu os princípios em prol da mobilização de recursos morais, materiais e humanos para a construção de uma sociedade mais justa, sustentável e pacífica.

Com uma perspectiva crítica sobre o modelo de desenvolvimento hegemônico, discutiu a ausência de temas estruturantes como os desastres ambientais, o produtivismo e o consumismo da sociedade contemporânea, a obsolescência programada, o crescimento na produção e a destinação inadequada dos resíduos e o crescimento da miséria e da desigualdade nos eventos da Conferência Oficial que, segundo os signatários, estava mais centrada nos debates sobre os ajustes e as negociações econômicas, bem como na celebração das diretrizes dominantes sobre a problemática ambiental, sob o manto da ideologia do desenvolvimento sustentável.

O Fórum primou pelo atendimento das necessidades básicas do ser humano, pela necessidade de que as soluções fossem implantadas com o envolvimento de diferentes sujeitos sociais, de modo a minimizar e ou neutralizar os efeitos da 
degradação ambiental, pelos valores universalistas, pela interdependência global e pela responsabilidade compartilhada.

Além desses pontos, referendou o respeito à democracia, à diversidade cultural e ambiental, à complexidade e interdependência das questões ambientais, que demandavam a reformulação dos atuais modelos de desenvolvimento.

A Declaração do Rio sobre Meio Ambiente e Desenvolvimento elaborada pela Cúpula da Terra formulou 27 princípios objetivando a conclusão de acordos internacionais, direcionados a proteção da integridade do sistema global do meio ambiente e desenvolvimento.

Em seus capítulos quinto, sexto, sétimo, oitavo e nono, que tratavam da cooperação internacional mirando o desenvolvimento sustentável, ficaram estabelecidos que os Estados com responsabilidades comuns, porém diferenciadas, teriam o dever de erradicar a pobreza, a fim de reduzir as disparidades de padrões de vida e melhor atender às necessidades da maioria da população do mundo, de inserir a proteção ambiental como parte integrante do processo de desenvolvimento, dando prioridade à situação e às necessidades dos países em desenvolvimento, especialmente daqueles menos desenvolvidos e ecologicamente mais vulneráveis, fomentando a capacidade endógena para o desenvolvimento.

Para tanto, os Estados deveriam reduzir e eliminar os padrões insustentáveis de produção e consumo, promover políticas demográficas adequadas e o exercício da cidadania, estimular a compreensão científica por meio do intercâmbio de conhecimentos científicos e tecnológicos, intensificando o desenvolvimento, a adaptação, a difusão e a transferência de tecnologias, incluindo as tecnologias inovadoras, adotar uma legislação ambiental eficaz e cooperar na promoção de um sistema econômico internacional aberto e favorável ao crescimento econômico e ao desenvolvimento sustentável.

Os Estados deveriam ainda elaborar uma legislação nacional relativa à responsabilidade e à indenização das vítimas de poluição e de outros danos ambientais e desestimular e prevenir a realocação e transferência, para outros Estados, de atividades e substâncias que causassem degradação ambiental grave ou que fossem prejudiciais à saúde humana, observando o princípio da precaução, mesmo sem a certeza científica absoluta do dano ambiental. 
Além desses princípios, os Estados deveriam promover a internacionalização dos custos ambientais e do uso de instrumentos econômicos, para que o poluidor arcasse com o custo da poluição, atentando-se ao interesse público e sem provocar distorções no comércio e nos investimentos internacionais.

Ferrari (2014) argumentou que a Declaração do Rio sobre Meio Ambiente e Desenvolvimento pode ser entendida como o primeiro documento consensual produzido no âmbito das Nações Unidas a trazer uma série de princípios que buscava reconhecer o direito ao desenvolvimento e suas responsabilidades individuais e coletivas, ao mesmo tempo em que reconhecia a pressão sobre o meio ambiente, oriunda dos padrões de produção e consumo dos países desenvolvidos.

Discordamos da perspectiva apontada por Ferrari, tendo em vista que a Declaração do Rio sobre Meio Ambiente e Desenvolvimento foi resultado de grandes batalhas entre os países centrais e os chamados periféricos, ou seja, a sua elaboração decorreu de um conjunto de atos diplomáticos na busca por equacionar precários consensos.

No início da década de 1980, com as evidências científicas sobre as emissões de gases de efeito estufa advindas das atividades humanas à mudança do clima global começou a despertar a preocupação pública, inspirando uma série de conferências internacionais que apelavam para a urgência de um tratado mundial para enfrentar o problema ${ }^{6}$.

Em 1988, a Organização das Nações Unidas criou o espaço Painel Intergovernamental sobre Mudanças Climáticas, conhecido como IPCC, órgão político e técnico vinculado à Organização Meteorológica Mundial - OMM e ao Programa das Nações Unidas para o Meio Ambiente - PNUMA, com o objetivo de processar informações científicas, técnicas e socioeconômicas, obtidas por meio de pesquisas e estudos científicos sobre os efeitos e impactos gerados pelas mudanças climáticas, buscando alternativas e possíveis soluções.

\footnotetext{
6 "Convenção sobre Mudanças do Clima: o Brasil e a Convenção Quadro das Nações Unidas", editado pelo Ministério da Ciência e Tecnologia com o apoio do Ministério das Relações Exteriores da República Federativa do Brasil (1993).
} 
O IPCC foi dividido em três grupos de trabalho, sendo o primeiro relacionado à base da ciência física, o segundo ao impacto, adaptação e vulnerabilidade e terceiro a mitigação da mudança climática.

Como resultado desses grupos, o IPCC produziu relatórios com conclusões para os formuladores e executores de políticas demonstrando a necessidade de estabilizar as concentrações de gases de efeito estufa na atmosfera, decorrentes das ações antrópicas, evitando que essas interferissem de forma prejudicial e permanente no sistema climático do planeta.

Em 1990, a Assembleia Geral das Nações Unidas estabeleceu o Comitê Intergovernamental de Negociação para a Convenção Quadro sobre Mudança do Clima, que preparou a redação final que foi aprovada na Convenção sobre Mudanças Climáticas na Conferência Rio 92, com o objetivo de alcançar a estabilização das concentrações de gases de efeito estufa na atmosfera num nível que impedisse uma interferência antrópica perigosa no sistema climático.

De acordo com a Convenção, esse nível deveria ser alcançado num prazo suficiente que permitiria aos ecossistemas adaptarem-se naturalmente à mudança do clima, que assegurasse que a produção de alimentos não fosse ameaçada e que permitisse o desenvolvimento econômico prosseguir de maneira sustentável.

Para alcançar o objetivo proposto e implantar as suas disposições as Partes assinantes da Convenção deveriam: (1), proteger o sistema climático em benefício das gerações presentes e futuras com base na equidade e em conformidade com suas responsabilidades comuns, mas diferenciadas, sendo que os países desenvolvidos deveriam tomar a iniciativa no combate à mudança do clima e a seus efeitos; (2), levar em consideração as necessidades dos países em desenvolvimento, em especial aqueles particularmente mais vulneráveis aos efeitos negativos da mudança do clima; (3), adotar medidas de precaução para prever, evitar ou minimizar as causas da mudança do clima e mitigar seus efeitos negativos, sem postergar medidas alegando a falta de plena certeza científica; (4), adotar políticas e medidas para proteger o sistema climático contra mudanças induzidas pelo homem adequadas às condições específicas, integrando-as aos programas nacionais de desenvolvimento econômico e (5) cooperar para promover um sistema econômico internacional favorável e aberto conducente ao crescimento e ao desenvolvimento econômico sustentáveis, em especial dos países em desenvolvimento, visando enfrentar os problemas das mudanças climáticas. 
Como destacou Lago (2007), a Convenção sobre Mudanças Climáticas foi marcada por profundas divergências entre os países Norte e Sul, pois de um lado havia o discurso das incertezas científicas sobre o aquecimento global e do alto custo econômico para cumprir as metas sugeridas, e de outro lado, os países que já haviam progredido na diminuição de emissão de gases e cujos gastos para atingir as primeiras metas não pareciam proibitivos e que, portanto, achava necessário que todos os países também diminuíssem as suas emissões.

Albuquerque (2008) concordou com Lago e reforçou o seu argumento afirmando que nessa disputa discursiva havia por parte dos países desenvolvidos e mais poluidores o questionamento dos modelos e das explicações científicas sobre o aquecimento global, ignorando dessa forma, o princípio da precaução, e fortalecendo a corrente tecnicista, calcada na ideia de que o desenvolvimento tecnológico poderia apresentar soluções e condições melhores e mais baratas para mitigar causas e efeitos do aquecimento.

Nessa disputa, os países mais poluidores, em particular os Estados Unidos venceram a queda de braço e, como demonstrou Oliveira (2011), as constatações e orientações do IPCC sobre emissões de $\mathrm{CO}^{2}$ foram extraídas do texto final, transformando a Convenção sobre Mudanças Climáticas.

Assim concluímos que o documento oficial assinado por 154 países e mais a comunidade europeia, tendo como objetivo alcançar, em conformidade com as disposições pertinentes desta Convenção, a estabilização das concentrações de gases de efeito estufa na atmosfera num nível que impedisse uma interferência antrópica perigosa no sistema climático, foi frágil, vago, genérico e sem metas e prazos claramente definidos em torno da redução das emissões gases poluentes.

Isto é, como afirmou Oliveira (2011), foi um conjunto de ideias sem implicações para ações concretas, que apesar de reconhecer os efeitos negativos da mudança climática para a humanidade, não propôs medidas para conter a matriz energética, nem alterações dos padrões de desenvolvimento vigente.

$\mathrm{Na}$ década de 1980, conforme sinalizou Mota e Godinho (2013), a Organização das Nações Unidas convocou os países e as organizações internacionais para discutir aspectos referentes à conservação e utilização sustentável da biodiversidade, com a finalidade de elaborar um instrumento jurídico de âmbito internacional. 
Como resultado dessas negociações, destacaram os autores, a Convenção sobre a Diversidade Biológica foi apresentada, aprovada e assinada por 154 países durante a Conferência Rio 92, entrando em vigor em 29 de dezembro de 1993, tendo como objetivos a conservação da diversidade biológica, a utilização sustentável de seus componentes e a repartição justa e equitativa dos benefícios derivados da utilização dos recursos genéticos.

A Convenção sobre a Diversidade Biológica foi estruturada com um preâmbulo, 42 artigos, dois anexos e duas partes referentes à arbitragem e conciliação, tratando dos objetivos, princípios, propostas de ações destinadas à conservação e utilização sustentável dos componentes da diversidade biológica, acesso aos recursos genéticos, transferência de tecnologia e biotecnologia, recursos financeiros, mecanismos financeiros, dentre outros aspectos.

O documento reconheceu o valor ecológico, genético, social, econômico, científico, educacional, cultural, recreativo e estético da diversidade biológica e de seus componentes e a sua importância para a evolução e para a manutenção dos sistemas necessários à vida da biosfera, sendo a sua conservação uma preocupação comum à humanidade.

Reconheceu também que os Estados têm direitos soberanos sobre os seus próprios recursos biológicos e a responsabilidade pela utilização sustentável da diversidade biológica e, assim, promover informações e conhecimentos por meio de capacitação científica, técnica e institucional para prever, prevenir e combater na origem as causas da sensível redução ou perda da diversidade biológica é missão dos Estados.

A Convenção reconheceu ainda a estreita e tradicional dependência de recursos biológicos de muitas comunidades locais e populações indígenas, e que era desejável repartir equitativamente os benefícios derivados da utilização do conhecimento tradicional, de inovações e de práticas relevantes à conservação da diversidade biológica e à utilização sustentável de seus componentes.

Além desses princípios, a Convenção enfatizou a necessidade de promover a cooperação internacional, regional e mundial entre os Estados e as organizações intergovernamentais e o setor não governamental para a conservação da diversidade biológica e a utilização sustentável de seus componentes.

Para tanto, reconheceu o papel do desenvolvimento econômico e social, dos recursos financeiros, do acesso adequado às tecnologias, da erradicação da 
pobreza para modificar sensivelmente a capacidade mundial de enfrentar a perda da diversidade biológica.

Lago (2007) argumentou que a Convenção sobre Diversidade Biológica exigiu muitas negociações em busca de um recorte satisfatório para conciliar os interesses dos países desenvolvidos, que possuem a grande maioria dos recursos tecnológicos e financeiros para explorar os patrimônios genéticos do mundo e dos países em desenvolvimento que possuem dois terços dos recursos genéticos.

O autor ressaltou que, apesar de terem sido feitas na Convenção várias concessões aos Estados Unidos, em particular sobre a propriedade intelectual, a mesma só foi assinada no governo Clinton, mesmo assim não sendo ratificada. $\mathrm{A}$ alegação para tal posicionamento segundo o autor foi à seguinte:

Grande parte da tecnologia foi desenvolvida e patenteada por empresas privadas, a sua transferência, segundo os países industrializados, deveria ser feita segundo as normas de proteção da propriedade intelectual e de acordo com as regras de mercado (LAGO, 2007, p. 75).

Levando em consideração que a biodiversidade é uma fonte estratégica para impulsionar o desenvolvimento econômico e que a maior parte da biodiversidade mundial se encontra nos países em desenvolvimento.

E ainda, que de acordo com os termos da Convenção, o acesso aos recursos biológicos e genéticos deve estar sujeito a autorização dos países de origem e das populações tradicionais detentoras dos conhecimentos associados à biodiversidade e que os benefícios de sua utilização devem ser compartilhados de forma justa e equitativa com esses países e suas populações, a negativa dos Estados Unidos em não ratificar a convenção foi extremamente ilustrativa no sentido de desnudar os seus interesses econômicos, em detrimento da preservação ambiental, particularmente da diversidade biológica.

A Convenção sobre Diversidade Biológica constituiu um novo marco regulatório sobre a conservação e o uso sustentável da diversidade biológica, estabelecendo uma distribuição equitativa dos benefícios advindos da biodiversidade. Além disso, instituiu o princípio da soberania dos Estados sobre os recursos biológicos e genéticos existentes em seus territórios. Além disso reconheceu e valorizou o conhecimento e as práticas das populações tradicionais ligadas à biodiversidade e colocou à vista as problemáticas da destruição da 
biodiversidade e da biopirataria. Entretanto, o documento da Convenção sobre Diversidade Biológica possui diversas lacunas.

Em primeiro lugar, não definiu metas e prazos claros a serem alcançados. Em segundo, não definiu mecanismos de verificação das obrigações, nem de sanção para o descumprimento de suas diretrizes. Em terceiro, não evidenciou regras claras sobre as compensações para as populações tradicionais pelo uso da biodiversidade e conhecimento destas populações. Em quarto, nota-se claramente uma oposição entre os preceitos da Convenção da Diversidade Biológica e da Organização Mundial do Comércio - OMC, tendo em vista que a OMC estabeleceu que o comércio internacional ocorreria de forma totalmente livre. Vale ressaltar, que no choque entre estes dois regimes internacionais, apenas a OMC, que possui como objetivo eliminar barreiras comerciais tem mecanismos para sancionar o descumprimento de seus preceitos.

Por fim, e não menos importante, cabe destacar que os países detentores da maior parte da tecnologia e da biotecnologia, por meio dos direitos de propriedade intelectual, particularmente da patente, ao desenvolverem determinados produtos provenientes da biodiversidade e dos conhecimentos a elas associados se tornam "proprietários" desses, ocorrendo assim um evidente descumprimento da Convenção sobre Diversidade Biológica.

Bezerra (2012) afirmou que, foi a partir de 1980, com a repercussão internacional do desmatamento de florestas tropicais, com destaque para o Brasil, que o tema se tornou uma questão política importante e passou a ocupar um lugar central na arena política internacional, inclusive sendo posta na agenda oficial da Conferência Rio 92.

No entanto, essa autora destacou que, apesar ser um dos principais eixos de discussão da Conferência Rio 92, já havia sido inviabilizado nas preparatórias em decorrência da existência de uma disputa entre Norte (Estados Unidos, Canadá e União Europeia), defensores do princípio da responsabilidade global sobre a preservação de florestas e das florestas tropicais como patrimônio do mundo e os países do Sul, defensores da soberania dos Estados e do aumento da ajuda financeira, com a finalidade de pagar pela conservação das reservas florestais.

Assim, a discussão deu origem à "Declaração de Princípios com Autoridade Juridicamente Não Obrigatória para um Consenso Global sobre Manejo, a Conservação e o Desenvolvimento Sustentável de Todos os Tipos de Florestas", 
contendo os princípios referentes à gestão, à conservação e ao desenvolvimento sustentável das florestas.

É importante argumentar que o debate na Conferência Rio 92 sobre a necessidade de conservação das florestas não resultou em uma convenção com força legal, como no caso da mudança climática e da biodiversidade, o que demonstrou a complexidade da temática. Todavia, como desdobramento, enfatizou Bezerra (2012), os Estados membros da Organização das Nações Unidas (ONU) criaram o Painel Intergovernamental sobre Florestas que teve quatro encontros entre 1995 e 1997.

Principal documento da Conferência Rio 92, a Agenda 21 foi segundo Albuquerque (2008) um compromisso firmado entre 179 chefes de Estado e de Governo com a finalidade de se criar um plano de ação para definir as diretrizes e os instrumentos de planejamento para alcançar o desenvolvimento sustentável.

Nela, foi abordada a dimensão social e econômica do desenvolvimento sustentável, a gestão dos recursos naturais para o desenvolvimento sustentável, o fortalecimento dos grupos sociais na implantação do objetivo do desenvolvimento sustentável e os meios de implantação - recursos e mecanismos financeiros, instituições, tecnologia e instrumentos jurídicos para o desenvolvimento sustentável.

A Agenda 21 foi divida em 01 Preâmbulo e 04 seções compostos de 40 capítulos. No preâmbulo foi apresentado o dilema vivido pela sociedade moderna marcada pela perpetuação das disparidades entre as nações e no interior delas, pelo agravamento da pobreza, da fome, das doenças e do analfabetismo e pela deterioração contínua dos ecossistemas do planeta, da qual a humanidade depende para viver. Na Agenda 21 o caminho apontado para superação deste quadro foi o desenvolvimento sustentável, perspectiva vinculante entre desenvolvimento e meio ambiente.

A Agenda 21 destacou a responsabilidade mútua para a concretização de uma sociedade sustentável. Neste contexto, ressaltou o papel central dos Governos na construção de políticas com estratégias, planos e processos e da participação pública, do envolvimento ativo das organizações não governamentais e da necessidade da cooperação internacional.

O documento reconheceu que para alcançar o cumprimento dos objetivos da Agenda 21 acerca do desenvolvimento e do meio ambiente seriam 
imprescindíveis recursos financeiros para os países em desenvolvimento solucionarem os problemas ambientais e acelerarem o desenvolvimento sustentável.

A seção I, referente às dimensões sociais e econômicas, foi composta de 07 capítulos tratando dos temas cooperação internacional para acelerar o desenvolvimento sustentável dos países em desenvolvimento, combate à pobreza, mudanças no padrão de consumo, dinâmica demográfica e sustentabilidade, proteção da saúde humana, promoção do desenvolvimento sustentável nos assentamentos humanos e integração entre desenvolvimento e meio ambiente para a tomada de decisões.

A seção II, composta por 14 capítulos relacionados à conservação e gestão dos recursos para o desenvolvimento, tratou dos seguintes temas: proteção atmosférica, planejamento integrado da gestão dos recursos terrestres, combate ao desflorestamento, a desertificação, a seca, promoção do desenvolvimento rural e agrícola, conservação da biodiversidade e manejo sustentável da biotecnologia, proteção das montanhas, oceanos, mares, zonas costeiras, dos recursos hídricos, manejo ecologicamente saudável de substâncias tóxicas e perigosas e manejo ambientalmente saudável de resíduos perigosos, radioativos e dos resíduos sólidos. Este último, constituinte do objeto de análise desta pesquisa.

Na seção III, composta de 09 capítulos, foram tratados temas referentes ao fortalecimento dos principais grupos que colaboram para o desenvolvimento sustentável, entre eles: as autoridades locais, as mulheres, as crianças e os jovens, as populações indígenas, as organizações não governamentais, os trabalhadores e seus sindicatos, os empresários, a comunidade científica, os agricultores.

A seção IV abordou os meios para implantação da Agenda 21, orientando para os recursos e mecanismos de financiamento, a importância do fortalecimento institucional, da transferência de tecnologia, da ciência e da educação e de mecanismos jurídicos internacionais para a tomada de decisões com a finalidade de alcançar o desenvolvimento sustentável.

A tese não possui como objetivo analisar detalhadamente todos os 40 capítulos da Agenda 21, todavia pontuaremos alguns aspectos dos capítulos 2, 3, 4,5 , e 21, que consideramos fundamentais para a nossa reflexão.

No capítulo 2 da seção I, que se refere à cooperação internacional para acelerar o desenvolvimento sustentável dos países em desenvolvimento foi 
destacado o papel central do comércio, bem como da necessidade de alocação de recursos financeiros aos países em desenvolvimento para estimular as políticas econômicas favoráveis ao desenvolvimento sustentável.

O capítulo 3 reconheceu a pobreza como um problema complexo e multidimensional, com origem ao mesmo tempo na área nacional e internacional e que o seu combate é uma responsabilidade conjunta de todos os países e requisito básico para a existência de desenvolvimento sustentável.

Para tanto, se faz necessário a promoção de um crescimento econômico nos países em desenvolvimento associado a uma ação direta visando o fortalecimento dos programas de emprego e de renda, bem como a capacitação dos pobres para a obtenção de meios de subsistência sustentáveis.

O capítulo 4 da Agenda 21 reconheceu os padrões insustentáveis de produção e consumo, especialmente nos países industrializados como principais causas da deterioração ininterrupta do meio ambiente mundial e do agravamento da pobreza.

Assim sendo, promover padrões de produção e consumo que reduzam as pressões sobre os recursos naturais e o desperdício, bem como o desenvolvimento de novos conceitos de crescimento econômico sustentável e de prosperidade, capazes de permitir a melhoria nos níveis de vida, atendendo às necessidades básicas da humanidade apresentam-se como medidas imprescindíveis.

Além desses aspectos, o capítulo 4 enfatizou que a sociedade precisa desenvolver formas eficazes de tratar os resíduos, reduzindo-o ao mínimo, numa ação conjunta entre as indústrias, as famílias e o público em geral, por meio do estímulo à reciclagem no nível dos processos industriais e do produto consumido, da redução do desperdício na embalagem dos produtos e pelo estímulo à introdução de novos produtos ambientalmente saudáveis.

O capítulo 5 da Agenda 21, que abordou a relação entre a dinâmica demográfica e a sustentabilidade, afirmou que o crescimento da população mundial e da produção associada a padrões não sustentáveis de consumo exercem uma pressão cada vez mais intensa sobre as condições que tem nosso planeta de sustentar a vida.

O capítulo 21 intitulado "Manejo ambientalmente saudável dos resíduos sólidos e questões relacionadas com os esgotos", foi incorporado à Agenda 21 devido à necessidade de elaborar estratégias e medidas para deter e inverter os 
efeitos da degradação do meio ambiente, em particular do manejo ambientalmente saudável dos resíduos que se encontrava entre as questões mais importantes para a manutenção da qualidade do meio ambiente da Terra e, principalmente, para alcançar um desenvolvimento sustentável e ambientalmente saudável em todos os países.

Para Albuquerque (2008), a Agenda 21, ato simbólico de efetivação do desenvolvimento sustentável, é um documento frágil, que se concentra nas consequências sem discutir as causas da insustentabilidade do modelo de desenvolvimento dominante.

Assim, segundo o autor, as diretrizes de ação da Agenda 21 voltadas à promoção do desenvolvimento sustentável, legitimou o modelo de desenvolvimento hegemônico, que se baseou nos mecanismos de acumulação flexível e do mercado neoliberal. Portanto, não colocou em xeque o capitalismo e os seus mecanismos de controle e reprodução das condições materiais e simbólicas do capital.

Albuquerque (2008) destacou que enquanto em Estocolmo a problemática ambiental estava associada ao controle dos efeitos do desenvolvimento, como poluição e crescimento populacional, a Rio 92 incorporou a questão da pobreza ao debate ambiental, sendo fundamental para o equacionamento de ambas a aceleração do processo de desenvolvimento, assentado no avanço tecnológico e no crescimento econômico.

Nessa hipótese do "duplo caminho", a pobreza não foi entendida como causa fundamental da degradação, mas seria necessária a sua superação para resolver os efeitos da destrutividade ambiental.

Silva (2010) argumentou que essa|a hipótese é equivocada, porque além de não dar conta da totalidade, apartou a sustentabilidade ambiental da social, de tal sorte que a realização de ações no campo da primeira não assegura a segunda ou diretamente se opõem a ela.

Como destacou Oliveira (2011), diferentemente da Conferência de Estocolmo, onde ocorreu um descompasso entre os interesses econômicos e as propostas para o meio ambiente, tidas como prejudiciais ao capitalismo, na Conferência Rio 92 houve o encontro entre a proteção do meio ambiente e a economia, sob a égide do neoliberalismo e do desenvolvimento sustentável. 
Após a Conferência Rio 92 ocorreram outros encontros internacionais promovidos pela Organização das Nações Unidas para discutir o desenvolvimento e o meio ambiente, enfatizaremos a seguir os mais relevantes.

Em 1997 foi realizado o Fórum Rio+5, na cidade do Rio de Janeiro e a Conferência Internacional em Ambiente e Sociedade, na cidade de Thessaloníki, Grécia, ambos os eventos com o objetivo de fazer um balanço dos pressupostos adotados sobre desenvolvimento sustentável e os possíveis progressos ocorridos após a Conferência Rio 92.

Em setembro de 2000, em Nova Iorque, foi realizada pela Organização das Nações Unidas a Cúpula do Milênio, contando com a presença de representantes de 190 países reunidos para debater os principais problemas da agenda internacional do novo milênio.

Como desdobramento dos debates realizados durante esse evento, estabeleceram-se os oito objetivos de Desenvolvimento do Milênio (ODM), por meio da "Declaração do Milênio", que deveriam ser alcançados até 2015.

A "Declaração do Milênio" propôs erradicar a extrema pobreza e a fome, atingir o ensino básico universal, promover a igualdade entre os sexos e a autonomia das mulheres, reduzir a mortalidade na infância, melhorar a saúde materna, combater o HIV/Aids, a malária e outras doenças, garantir a sustentabilidade ambiental e estabelecer uma parceria mundial para o desenvolvimento.

No dia 11 de setembro ocorreu o atentando terrorista nos Estados Unidos, que acarretou numa nova configuração geopolítica mundial, alterando a agenda política, tornando à segurança internacional e o combate ao terrorismo a pauta central, deixando a temática ambiental fora das prioridades da agenda internacional, mesmo diante de uma série de desastres ecológicos pelo mundo.

Em novembro de 2001, dois meses após os atentados terroristas nos Estados Unidos, ocorreu na capital do Catar, a Conferência de Doha ou Rodada do Desenvolvimento, com objetivo de discutir entre os 153 países que formavam a Organização Mundial do Comércio a liberalização do comércio mundial e o fim do protecionismo.

Nela reafirmou-se o comprometimento com o desenvolvimento sustentável, alegando que o crescimento econômico e salvaguarda de um sistema de comércio 
multilateral aberto e não discriminatório eram conciliáveis com a atuação para a proteção do meio ambiente.

Entretanto, o que se verificou contrapondo-se a Declaração firmada em Doha é que o "livre comércio" tem contribuído para ampliar o abismo entre os países desenvolvidos e em desenvolvimento, a desigualdade social, degradação e as injustiças ambientais.

Realizada em março de 2002 no México, a Conferência sobre Financiamento do Desenvolvimento ou Conferência de Monterrey reuniu 51 presidentes e primeiros-ministros, além de inúmeros dirigentes instituições financeiras e representantes da sociedade civil, com o objetivo de enfrentar os desafios do financiamento ao desenvolvimento e os meios para mobilizar os recursos para erradicar a pobreza, alcançar o crescimento econômico sustentável e promover o desenvolvimento sustentável no contexto de um sistema econômico mundial justo e que favoreça a inclusão.

$\mathrm{Na}$ Conferência de Monterrey foi estabelecida a incumbência de promover a mobilização dos recursos internos, o aumento do investimento privado internacional, o reforço da ajuda pública ao desenvolvimento - APD, o alargamento do acesso aos mercados e garantia de um comércio em condições justas, a resolução da questão da dívida e melhoria da coerência das estruturas financeiras mundiais e regionais, e a promoção de uma representação justa dos países em desenvolvimento no processo de tomada de decisões a nível mundial. Mas, no campo prático as expectativas não lograram êxito.

Segundo Lago (2007), a Conferência de Joanesburgo realizada pela Organização das Nações Unidas, entre 02 e 04 de setembro de 2002, em Joanesburgo, na África do Sul, contou com a presença de líderes de 189 países, de centenas de Organizações Não Governamentais (ONGs) e representantes da sociedade civil e teve como objetivo uma "revisão decenal do progresso alcançado na implantação dos resultados da Conferência das Nações Unidas sobre o Meio Ambiente e Desenvolvimento".

Da Conferência de Joanesburgo resultaram dois documentos fundamentais, a saber: a Declaração de Joanesburgo sobre Desenvolvimento Sustentável e o Plano de Implementação da Cúpula Mundial sobre Desenvolvimento Sustentável. Ambos os documentos reafirmam a adesão aos princípios e o plano de ação para a conquista do desenvolvimento sustentável, à plena implantação da Agenda 21 e 
cumprimento dos objetivos internacionalmente acordados com relação ao desenvolvimento, bem como as principais deliberações da Conferência Rio 92.

A Declaração de Joanesburgo sobre Desenvolvimento Sustentável reconheceu que mesmo após 10 anos da realização da Conferência Rio 92 e dos acordos estabelecidos, o meio ambiente global continuava sofrendo degradação e que a humanidade se encontrava numa encruzilhada.

A perda de biodiversidade, dos estoques pesqueiros, a desertificação, os efeitos adversos da mudança do clima, os desastres naturais mais frequentes e mais devastadores, a poluição do ar, da água e do mar, que seguia privando milhões de pessoas de uma vida digna eram acontecimentos incontestes desse processo ocasionado pelo modelo hegemônico predatório.

Diante desSe cenário, os documentos estabeleceram a erradicação da pobreza, a mudança dos padrões de consumo e produção e a proteção e o manejo da base de recursos naturais para o desenvolvimento econômico e social como sendo objetivos fundamentais e requisitos essenciais do desenvolvimento sustentável.

O Plano de Implementação da Cúpula Mundial sobre Desenvolvimento Sustentável reconheceu a necessidade de promover um ambiente econômico que favorecesse a cooperação internacional e a participação plena e efetiva dos países em desenvolvimento no processo de tomada de decisões em nível global, para reduzir a distância entre os países desenvolvidos e em desenvolvimento, em particular nas áreas de finanças, transferência de tecnologia, dívida e comércio.

Apesar de sinalizar para essa direção, a Conferência de Joanesburgo desde sua fase preparatória apresentava impasses e obstáculos, sobretudo a ausência de interesse dos Estados Unidos, da União Europeia, do Grupo dos 77, da China e de outros países de assumirem metas mais ambiciosas, tais como a redução da emissão de gases poluentes, que consequentemente, pudessem comprometer as suas atividades industriais e as suas economias.

Como sinalizou Lago (2006), esSes países não estariam dispostos a "ir mais além de Doha e Monterrey".

Lago (2007) argumentou ainda que o mais significativo resultado da Cúpula de Joanesburgo incluiu, na maioria das opiniões, a fixação ou a reafirmação de metas para a erradicação da pobreza com a decisão política de criação de fundo mundial de solidariedade, controle de produtos químicos perigosos, a inclusão de 
dois temas de difícil progresso em inúmeras negociações anteriores - energias renováveis e responsabilidade corporativa - e o fortalecimento do conceito de parcerias entre diferentes atores sociais para a dinamização e eficiência de projetos.

No entanto, como destacou Lago (2007), a chamada "Era de Cooperação Internacional pós Guerra Fria” não se materializou, a perspectiva de que haveria o deslocamento de parte do orçamento militar mundial para Ajuda Oficial ao Desenvolvimento (ODA) e outras iniciativas que pudessem favorecer o desenvolvimento sustentável não se consolidaram, sobretudo pós-ataque terrorista nos Estados Unidos.

No contexto de fortalecimento da liberalização do mercado, a Conferência de Joanesburgo deixou clara a não pretensão, sobretudo dos países desenvolvidos, de colocar em prática os princípios e as pautas da Agenda 21. Além disso, evidenciou o enfraquecimento dos Estados e a sua subordinação às grandes multinacionais, principais responsáveis pelos processos decisórios em escala mundial.

Os documentos finais de Joanesburgo não estabeleceram metas sobre o que precisava ser feito, quando precisava, e com quais financiamentos seriam realizados, assim funcionou apenas como cartas de boas intenções sem nenhum desdobramento prático.

Ou seja, os grandes poluidores apregoavam a necessidade de alterações no modelo societário com objetivo de reverter o quadro de degradação social e ambiental, mas sem na prática executar nenhuma mudança estrutural no comércio internacional, nas políticas de ajuda aos países em desenvolvimento, em particular em relação à dívida externa, a transferência de tecnologia e dos subsídios para exportação agrícola.

Em Joanesburgo prevaleceu a força do comércio sobre as questões referentes aos direitos humanos, sociais e ambientais. A OMC se fortaleceu em âmbito mundial e confirmou seu papel crescente nas políticas internacionais, na qual os acordos ambientais tornaram-se subservientes às regras mercantis impostas.

O Estado enfraquecido com as políticas neoliberais ao invés de exercer a sua responsabilidade na promoção de políticas sociais universalizantes passou a 
atuar na implantação dos interesses do capital, contrariando interesses da coletividade.

Em outros termos, há em Joanesburgo a radicalização do processo de apropriação pelos organismos internacionais da questão ambiental, com o discurso de conciliação entre o crescimento econômico e a sustentabilidade ecológica, no entanto sem colocar em xeque a lógica do mercado no contexto da mundialização do capital.

Segundo Ferrari (2014), a Conferência das Nações Unidas sobre Desenvolvimento Sustentável ou Rio+20, foi realizada entre os dias 13 e 22 de junho de 2012, no Rio de Janeiro, reunindo 191 Estados-Membros da Organização das Nações Unidas, 85 organismos internacionais e agências especializadas da ONU e contou com a presença de 80 chefes de Estado ou de Governo, sete vice-presidentes, nove vice-primeiros-ministros e mais 487 ministros de Estado.

Assim como na Conferência Rio 92, a Conferência Rio+20 teve dois eventos paralelos.

No Riocentro ocorreram os debates, as discussões e as decisões dos chefes de Estado, com o objetivo da renovação do compromisso com o desenvolvimento sustentável e com a promoção de um futuro econômico, social e ambientalmente sustentável para o nosso planeta e para as atuais e futuras gerações, tendo como foco a avaliação do progresso e das lacunas na implantação das decisões adotadas pelas principais cúpulas sobre o assunto e do tratamento de temas novos e emergentes.

No Aterro do Flamengo foi realizada a Cúpula dos Povos, organizada por entidades da sociedade civil e movimentos sociais de vários países, com as finalidades de discutir as causas da crise socioambiental e as suas falsas soluções e fortalecer movimentos sociais do Brasil e do mundo, dando voz às comunidades diretamente ligadas às localidades mais atingidas pelos problemas socioambientais.

Como desdobramentos dos debates e reflexões na Cúpula dos Povos foi produzido o documento intitulado "Cúpula dos Povos na Conferência Rio+20 por Justiça Social e Ambiental, Contra a Mercantilização da Vida e em Defesa dos Bens Comuns", na qual fora realizada uma profunda crítica ao modelo hegemônico e às propostas falaciosas, superficiais e genéricas do documento " $\mathrm{O}$ 
futuro que queremos", para resolver a chamada "crise ambiental", bem como uma crítica contundente ao poder das corporações e da iniciativa privada nas negociações da Conferência Rio+20 e a subserviência das Organizações das Nações Unidas aos interesses econômicos dessas instituições.

Nela, ficou estabelecido que a transformação social exigiria convergências de ações, articulações e agendas das resistências e alternativas contra hegemônicas ao sistema capitalista, tendo como principais eixos de luta as seguintes:

a) Contra a militarização dos Estados e territórios; b) Contra a criminalização das organizações e movimentos sociais; c) Contra a violência contra as mulheres; d) Contra a violência às lésbicas, gays, bissexuais, transexuais e transgêneros; e) Contra as grandes corporações; f) Contra a imposição do pagamento de dívidas econômicas injustas e por auditorias populares das mesmas; g) Pela garantia do direito dos povos à terra e ao território urbano e rural; h) Pela consulta e consentimento livre, prévio e informado, baseado nos princípios da boa fé e do efeito vinculante, conforme a Convenção 169 da OIT; i) Pela soberania alimentar e alimentos sadios, contra agrotóxicos e transgênicos; j) Pela garantia e conquista de direitos; k) Pela solidariedade aos povos e países, principalmente os ameaçados por golpes militares ou institucionais, como está ocorrendo agora no Paraguai; 1) Pela soberania dos povos no controle dos bens comuns, contra as tentativas de mercantilização; m) Pela mudança da matriz e modelo energético vigente; n) Pela democratização dos meios de comunicação; o) Pelo reconhecimento da dívida histórica social e ecológica; p) Pela construção do Dia Mundial de Greve Geral e de Luta dos Povos. (CÚPULA DOS POVOS, 2012, p. $4)$.

No Riocentro, onde ocorreram os debates, as discussões e as decisões dos chefes de Estado, elaborou-se o documento "O futuro que queremos", na qual se estabeleceu como temas principais a economia verde no contexto do desenvolvimento sustentável e a erradicação da pobreza e a estrutura institucional para o desenvolvimento sustentável.

Vale ressaltar, que pela primeira vez a sociedade civil fora convidada para participar do evento oficial das Conferências. Sem desconsiderar a relevância da prática inovadora da participação da sociedade civil nas esferas oficiais da ONU, arguimos que essa ação foi muito mais uma estratégia para tentar suavizar os conflitos e legitimar a Conferência Oficial, tendo em vista que os temas centrais como a equidade social, a distribuição desigual do poder, dos riscos e dos danos ambientais, o perdão da dívida externa, a exploração dos recursos naturais dos países periféricos pelos países desenvolvidos, o financiamento da agricultura familiar em contraponto ao agronegócio, a garantia dos direitos humanos, a justa 
transferência de tecnologia não foram contemplados no documento "O futuro que queremos".

No documento "O futuro que queremos" se reconheceu a importância central da erradicação da pobreza, da mudança dos modos de consumo e produção não sustentáveis e da gestão adequada dos recursos naturais e dos ecossistemas, que estruturam o desenvolvimento econômico e social para o desenvolvimento sustentável.

Reconheceu também que, para alcançá-lo, seria necessário promover o crescimento econômico e o desenvolvimento social sustentável, equitativo e inclusivo, criando oportunidades para todos, reduzindo as desigualdades, e melhorando consequentemente as condições básicas de vida.

“O futuro que queremos" reafirmou também a importância da liberdade, da paz e da segurança, do respeito aos direitos humanos, à alimentação, ao Estado de direito, à igualdade de gênero e ao empoderamento das mulheres e o compromisso com sociedades justas e democráticas.

Além disso, referendou os acordos internacionais, reafirmando o compromisso político de implantar os princípios da Declaração do Rio sobre Ambiente e Desenvolvimento, do Programa para a Implementação da Agenda 21, do Plano de Implementação da Cúpula Mundial sobre Desenvolvimento Sustentável e ratificou a Convenção Quadro das Nações Unidas sobre Mudança do Clima (UNFCCC), da Convenção sobre Diversidade Biológica (CDB) e da Convenção das Nações Unidas de Combate à Desertificação (UNCCD) e os Objetivos de Desenvolvimento do Milênio.

"O futuro que queremos" reconheceu ainda que os progressos obtidos desde a Conferência Rio 92 foram desiguais nas três dimensões do desenvolvimento e que em muitos casos houve retrocessos, agravados por várias crises financeiras, econômicas, alimentares e energéticas, que têm desafiado a capacidade de todos os países, em particular dos países em desenvolvimento, de realizar o desenvolvimento sustentável.

O documento destacou a relevância do acesso à água potável, à segurança alimentar, ao saneamento básico, à saúde, a educação, à energia, às proteções sociais, ao emprego pleno e produtivo, a igualdade de gênero, a necessidade da preservação dos oceanos, mares, montanhas, florestas, biodiversidades e da gestão integrada dos produtos químicos e resíduos, apresentando a "economia verde" no 
contexto do desenvolvimento sustentável e da erradicação da pobreza, como uma das importantes ferramentas para alcançar o desenvolvimento sustentável.

Para tanto, a "economia verde" deveria:

a) Estar em acordo com o direito internacional; b) Respeitar a soberania nacional de cada país sobre seus recursos naturais tendo em conta as suas especificidades nacionais, objetivos, responsabilidades, prioridades e espaço político em relação às três dimensões do desenvolvimento sustentável; c) Apoiar-se em um ambiente favorável e no bom funcionamento dos estabelecimentos de todos os níveis, com um papel de liderança para os governos e com a participação de todas as partes interessadas, incluindo a sociedade civil; d) Promover um crescimento econômico sustentável e inclusivo, favorecer a inovação, as oportunidades, benefícios e capacitação para todos e garantir o respeito de todos os direitos humanos; e) Levar em conta as necessidades dos países em desenvolvimento, particularmente aquelas em situações especiais; f) Reforçar a cooperação internacional, incluindo a provisão de recursos financeiros, capacitação e transferência de tecnologia para países em desenvolvimento; g) Evitar a imposição de condições injustificadas para a assistência pública ao desenvolvimento e ao financiamento; $h$ ) Não constituir um meio de discriminação arbitrária ou injustificável, ou uma restrição disfarçada ao comércio internacional, evitando ações unilaterais para lidar com desafios ambientais fora da jurisdição do país importador, e assegurar que as medidas de luta contra os problemas ambientais transfronteiriços ou globais, tanto quanto possível, baseiem-se em um consenso internacional; i) Contribuir para preencher as lacunas de tecnologia entre países desenvolvidos e em desenvolvimento e reduzir a dependência tecnológica dos países em desenvolvimento, utilizando todas as medidas adequadas; $\mathrm{j}$ ) Melhorar o bem-estar dos povos indígenas e suas comunidades, de outras comunidades locais e tradicionais, e das minorias étnicas, reconhecendo e apoiando a sua identidade, cultura e seus interesses; evitar pôr em perigo a sua herança cultural, suas práticas e conhecimentos tradicionais, preservando e respeitando as abordagens não comerciais que contribuem para a erradicação da pobreza; k) Melhorar o bem-estar das mulheres, crianças, jovens, pessoas com deficiência, pequenos agricultores e agricultores de subsistência, pescadores e aqueles que trabalham em pequenas e médias empresas, e melhorar as condições de vida e capacitação dos grupos pobres e vulneráveis, em particular nos países em desenvolvimento; 1) Mobilizar todo o potencial que oferecem homens e mulheres, e assegurar sua contribuição de forma igualitária; m) Promover, nos países em desenvolvimento, atividades produtivas que contribuam para a erradicação da pobreza; n) Atender às preocupações com as desigualdades e promover a inclusão social, incluindo os pisos de proteção social; o) Promover os modos de consumo e de produção sustentáveis; e p) Dar continuidade aos esforços realizados para estabelecer abordagens para um desenvolvimento equitativo e inclusivo, que permita combater a pobreza e a desigualdade. (RELATÓRIO DA CONFERÊNCIA RIO+20, 2012, P.12).

A Conferência Rio+20 não foi concebida como uma Reunião de Cúpula, mas apenas como uma "Conferência de revisão", sem a presença de muitos chefes de Estado e decisões relevantes como a revisão do sistema financeiro privado internacional ou dos padrões de consumo para melhorar a qualidade de vida da 
grande maioria da população mundial em situação de pobreza, desemprego, discriminação e exclusão política.

Diante do contexto geopolítico mundial de profunda crise econômica iniciada nos EUA e expandida para o mundo, o que se verificou na Conferência Rio+20 foi à construção de uma estratégia de renovação ideológica do capital, via "ecologização" da economia, com ampliação da produção e do consumo de forma mais sustentáveis e com baixo consumo de carbono.

Assim, o discurso da sustentabilidade por parte daqueles que provocaram e continuam a provocar a crise global, apareceu sem uma discussão profunda sobre as causas estruturais do processo de vulnerabilização e de injustiça social e ambiental.

Em outras palavras, sem um questionamento e uma proposta concreta para a superação dos padrões insustentáveis do modelo agro-urbano-industrial de produção e consumo, baseado na queima dos combustíveis fósseis, na distribuição e gestão dos recursos políticos, sociais, financeiros, culturais e naturais, na mercantilização da natureza, na exploração dos recursos naturais dos países em desenvolvimento, na exploração dos países do Hemisfério Sul pelos países do Hemisfério Norte, na exclusão das práticas tradicionais e dos saberes tradicionais de uso da terra e na distribuição do desigual do poder e dos riscos e danos ambientais.

Segundo o documento produzido pela Organização das Nações Unidas intitulado "Transformando Nosso Mundo: A Agenda 2030 para o Desenvolvimento Sustentável", nos dias 25, 26 e 27 de setembro de 2015, reuniram-se na sede das Nações Unidas, em Nova York, chefes de Estado e de Governo para discutir os novos Objetivos de Desenvolvimento Sustentável (ODS).

Como resultado do evento foi elaborado uma Agenda com um plano de ação para as pessoas e para o planeta, composta por 17 Objetivos de Desenvolvimento Sustentável e 169 metas, a serem consolidados nos próximos 15 anos, ou seja, até o ano de 2030.

Por um lado, o documento reconheceu o não cumprimento de vários objetivos traçados anteriormente e apontou para uma realidade de enormes desafios para o desenvolvimento sustentável, entre eles a crescente desigualdade entre os países, as enormes disparidades de oportunidades, riqueza e poder, as 
ameaças globais à saúde, os desastres naturais frequentes e intensos, os conflitos em ascensão, o extremismo violento, o terrorismo e as crises humanitárias relacionadas, o esgotamento dos recursos naturais e os impactos negativos da degradação ambiental, incluindo a desertificação, as secas, a degradação dos solos, a escassez de água doce e a perda de biodiversidade.

Por outro lado, o documento ressaltou o momento de enorme oportunidade, tendo em vista o progresso significativo feito no cumprimento de muitos desafios ao desenvolvimento, entre os quais a saída da pobreza extrema de centenas de milhões de pessoas, o aumento ao acesso à educação, a disseminação da informação e das tecnologias da comunicação e interconectividade global, que tem um grande potencial para acelerar o progresso humano, para eliminar o fosso digital e para o desenvolvimento de sociedades do conhecimento, assim para a inovação científica e tecnológica em áreas tão diversas como medicina e energia.

Diante dessa realidade, a ODS definiu como objetivos acabar com a pobreza em todas as suas formas, em todos os lugares, acabar com a fome, alcançar a segurança alimentar e a melhoria da nutrição e promover a agricultura sustentável, assegurar uma vida saudável e promover o bem-estar para todos, em todas as idades, assegurar a educação inclusiva e equitativa e de qualidade e promover oportunidades de aprendizagem ao longo da vida para todos.

Além desses pontos propuseram alcançar à igualdade de gênero e empoderar todas as mulheres e as meninas, assegurar a disponibilidade e gestão sustentável da água e saneamento para todos, assegurar o acesso confiável, sustentável, moderno e a preço acessível à energia para todos, promover o crescimento econômico sustentado, inclusivo e sustentável, emprego pleno e produtivo e trabalho decente para todos e infraestruturas resilientes e promover a industrialização inclusiva e sustentável e fomentar a inovação.

A ODS definiu ainda como objetivos reduzir a desigualdade dentro dos países e entre eles, tornar as cidades e os assentamentos humanos inclusivos, seguros, resilientes e sustentáveis, assegurar padrões de produção e de consumo sustentáveis, tomar medidas urgentes para combater a mudança do clima e seus impactos, conservar e usar de forma sustentável os oceanos, os mares e os recursos marinhos para o desenvolvimento sustentável, proteger, recuperar e promover o uso sustentável dos ecossistemas terrestres, gerir de forma sustentável as florestas, combater a desertificação, deter e reverter a degradação da terra e 
deter a perda de biodiversidade, promover sociedades pacíficas e inclusivas para o desenvolvimento sustentável, proporcionar o acesso à justiça para todos e construir instituições eficazes, responsáveis e inclusivas em todos os níveis e fortalecer os meios de implementação e revitalizar a parceria global para o desenvolvimento sustentável.

$\mathrm{Na}$ nossa perspectiva, a ODS, assim como as outras deliberações, apresentou bons objetivos rumo à sustentabilidade, todavia não sugeriu a alteração do modelo de desenvolvimento centrado no crescimento econômico como mola propulsora para resolução dos problemas socioambientais.

Ao nosso olhar, essas conferências foram fundamentais para colocar no centro do debate político a questão ambiental, para o crescimento de políticas ambientais e para se pensar os dilemas e possibilidades de conciliar o crescimento econômico, a sustentabilidade ambiental e a justiça social. Contudo, a perspectiva crítica defendida pelos movimentos sociais ambientalistas fora substituída por um discurso salvacionista e por uma estratégia para expansão do mercado e o controle dos patrimônios naturais, ou seja, para o prosseguimento e consolidação do capitalismo e do seu modelo de desenvolvimento.

Verificamos até o presente momento que diante da "crise ambiental", o paradigma do desenvolvimento sustentável, alicerçado nos preceitos da modernização ecológica, da ecoeficiência e da primazia da sustentabilidade ambiental sobre a sustentabilidade social tornou-se hegemônico, sendo o referencial para a implantação de políticas ambientais.

Nesta tese, em que objetivamos refletir sobre a política pública de resíduos sólidos no município do Arraial do Cabo, problematizamos a perspectiva do desenvolvimento sustentável como paradigma, evidenciando as suas limitações e baixa efetividade e mostramos que sob sua lógica a inclusão dos catadores e catadoras de materiais recicláveis ocorrerá precariamente reforçando processos de vulnerabilidades e de injustiças ambientais. 


\section{A Política Nacional de Resíduos Sólidos no Brasil: fragilidades, contradições, limites e possibilidades}

Diante dos questionamentos levantados se fez necessário estabelecer correlações com os trabalhos já consolidados. Por um lado, para evitar possíveis repetições e pesquisas de baixas contribuições científicas e acadêmicas e por outro, para colaborar com a elaboração de um recorte original.

Sendo assim, fizemos uma revisão bibliográfica sobre os trabalhos abordando as questões referentes aos resíduos sólidos e as políticas voltadas à gestão e o gerenciamento dos resíduos mais precisamente sobre a Política Nacional de Resíduos Sólidos no Brasil, evidenciando que os questionamentos, os problemas, os pressupostos, o arcabouço teórico e metodológico utilizados neste trabalho se inserem como desdobramentos de um desenvolvimento histórico.

Além desse aspecto, foi importante para mostrar os interlocutores com os quais dialogamos e as perspectivas com as quais coadunamos e com as quais não concordamos, bem como as lacunas que pretendemos identificar.

\subsection{O Estado da Arte dos Resíduos Sólidos e da Política Nacional de Resíduos Sólidos - PNRS}

Eigenheeer (2003) mostrou que a humanidade sempre produziu os resíduos como parte constituinte de sua própria existência, desde a forma mais simples, como as sobras da preparação dos alimentos e os excrementos humanos, até os próprios restos mortais. Nesse contexto, muitas sociedades desenvolveram estratégias para afastá-los para onde não criassem problemas para as atividades comunitárias.

Apesar dessas evidencias históricas e arqueológicas, diversos autores iniciaram a sua análise sobre os resíduos sólidos a partir da Idade Moderna, quando a produção e descarte se tornaram um problema sanitário, apresentando perigo à sociedade.

Os referidos trabalhos fizeram o recorte tomando como referencial a Revolução Industrial, que ensejou no acelerado crescimento urbano e populacional, com graves implicações habitacionais e sanitárias e na necessidade de adotar medidas para amenizar o quadro caótico da limpeza urbana, de contaminação das águas e da proliferação das doenças. 
$\mathrm{Na}$ contramão das abordagens históricas que partiram da Revolução Industrial, Eigenheer (2003) recuou até a Antiguidade e a Idade Média evidenciando informações das suas cidades, que segundo ele, possuem uma significativa contribuição para se apreender os princípios da limpeza urbana e para perceber como determinadas crendices, tabus e estigmas ${ }^{7}$ foram construídos sobre os resíduos e os operadores da limpeza urbana.

Além desse ponto, este recorte histórico permitiu visualizar a construção ambígua relacionada aos resíduos, sendo de um lado aceito, valorizado e reconhecido por sua utilidade e, por outro lado, a sua repulsa, nojo, rejeição e medo, que se estende deles para aqueles que o manipulam, o transportam, o reutilizam e o conduzem à disposição final.

Considerando a relevância dos períodos históricos da Antiguidade e da Idade Média, Eigenheer (2009), entretanto, relatou que foi a partir da segunda metade do século XIX, com o processo de urbanização e industrialização, que ocorreram profundas transformações na limpeza urbana, com o surgimento da teoria microbiana das doenças, em contraponto a concepção miasmática, provocando mudanças na concepção sobre a saúde pública, na atenção aos dejetos, na valorização da qualidade da água e na necessidade de se separar o esgoto dos resíduos sólidos.

No Rio de Janeiro, uma das cidades mais antigas do Brasil que foi capital da Colônia, do Império e da República, conforme destacou Eigenheer (2009), até a segunda metade do século XIX havia um quadro de precário de padrão higiênico, de saneamento e de limpeza urbana, na qual o esgoto e os resíduos sólidos não eram separados e como não havia uma localização específica para a sua disposição havia três formas de descartá-los.

A primeira, colocando-os no pátio das residências. A segunda, jogando nas valas e nas ruas. Em ambas as situações se esperava que as chuvas os escoassem até o mar. Já a terceira opção era o recolhimento dos dejetos em tonéis para que os escravos chamados de tigres $^{8}$ os despejassem na Baia de Guanabara.

\footnotetext{
${ }^{7}$ O estigma é entendido no trabalho como definido por Goffman (2008) em sua obra Estigma: notas sobre a manipulação da identidade deteriorada.

${ }^{8}$ Com a precariedade dos tonéis e os movimentos de caminhada, parte do conteúdo destes tonéis caía sobre a pele dos escravos, de modo que as costas dos mesmos passaram a receber, aos poucos, manchas semelhantes a dos tigres. Outras versões apontam que o apelido foi dado porque, ao avistar os negros levando barris de dejetos, os transeuntes, com medo de ficarem sujos, afastavam-
} 
Esses maus hábitos de higiene, associados ao crescimento populacional e urbano, a inoperância da Câmara Municipal, a ausência de lugares específicos para a disposição de rejeitos e as dificuldades encontradas para enterrá-los nas residências ou em suas imediações, em função de serem regiões pantanosas e úmidas e com o lençol freático muito alto, contribuíram para potencializar os problemas.

Com a chegada da Corte portuguesa, ressaltou Eigenheer (2009), visando melhorar o quadro de salubridade foram baixados editais para impedir que os rejeitos fossem jogados das casas nas ruas, para que cada morador mantivesse limpa a frente da sua propriedade e também para o ordenamento no despejo dos resíduos, fixando horários para os tigres, locais determinados, barris fechados para o seu recolhimento e carroças para o transporte.

Essas ações foram acompanhadas por medidas da Câmara Municipal, que procurou agir estabelecendo posturas referentes à limpeza da cidade.

De acordo com Mesquita (2004), em 1826 houve o primeiro pagamento efetuado pela administração pública a um particular pela realização de serviços de limpeza pública.

Além dessas ações, destacaram Aizen e Pechman (1985), outras medidas foram adotadas para a alteração desse cenário. A primeira foi à construção de pontes nas praias da Lapa, Santa Luzia, de D. Manuel, do Peixe, dos Mineiros, Prainha, Valongo e também na Cidade Nova e no Mangue do Aterrado ${ }^{9}$, que serviriam para lançar os rejeitos ao mar, entretanto, essa medida não surtiu o efeito desejado principalmente porque a população continuava a jogá-los pela cidade ou nas praias.

O quadro sanitário permanecia precário e piorou com a primeira grande epidemia de febre amarela em 1850. Diante dessa conjuntura e com a emergência de uma nova configuração econômica, com introdução do capital estrangeiro, em 1857, o Imperador D. Pedro II tomou uma segunda medida, assinando o contrato para o esgotamento sanitário da Cidade do Rio de Janeiro com João Frederico Russel e Joaquim Pereira Vianna para a construção e a administração da rede

se rapidamente, como se fugissem de um animal selvagem. Luccock, John (1959), apud Eigenheer (2009)

9 Aizen e Pechman informam que essas praias foram aterradas e extintas na Reforma Pereira Passos. 
pública de esgotos sanitários, bem como para executar as instalações de esgotos dos prédios nos limites da área central.

Nesse contrato, foi admitida a constituição de uma empresa inglesa, a The Rio de Janeiro City Improvements Company Limited, conhecida depois como City para realizar as obras do sistema de esgotamento sanitário, coordenada por Eduardo Gotto, membro do Instituto de Engenheiros Civis de Londres.

O projeto de Eduardo Gotto previu 03 distritos, a saber: o $1^{\circ}$ distrito inicialmente chamado de São Bento e depois de Arsenal, cujos esgotos eram conduzidos para a Casa de Máquinas do Arsenal, o $2^{\circ}$ distrito - da Gamboa, com os seus esgotos conduzidos para a Casa de Máquinas da Gamboa, o $3^{\circ}$ distrito da Glória, com os seus esgotos conduzidos para a Casa de Máquinas da Glória.

A Cidade do Rio de Janeiro foi à terceira cidade do mundo a ser dotada de rede de esgotos sanitários, precedida por Londres (1815) e Hamburgo (1842). Somente Londres, como Capital, se antecipou ao Rio na construção de suas redes de esgotos.

Em 1863, após a transferência do contrato de João Frederico Russel e Joaquim Pereira Vianna, a City se encarregou de construir e manter a rede de águas pluviais dos distritos localizados na área central. Em 1864 foi implantado o sistema de esgoto em parte da cidade do Rio de Janeiro, com a inauguração da Estação de Tratamento de Esgotos da Glória, com a presença do Imperador D. Pedro II e do Ministro de Obras Públicas.

Segundo Benchimol (1990), no mesmo ano, a companhia inglesa contratou a execução de novos serviços com o governo imperial, levando a rede de esgotos até os bairros de São Cristovão, Engenho Velho, Rio Comprido e Tijuca que formavam o $4^{\circ}$ distrito, estendendo-se, posteriormente, até o bairro dos Trapicheiros para atender as indústrias do local que se multiplicavam.

Benchimol (1990) destacou ainda que apesar de quantitativamente eficaz, tornando a cidade aparentemente mais asseada e menos fétida, as condições de salubridade pioraram com a contaminação do subsolo, sendo a prestação de serviço da companhia inglesa sempre criticada como de péssima qualidade, seja pelos moradores ou por registros oficiais, sobretudo nas áreas menos abastadas.

Para Eigenheer (2009), essa ação, mesmo deficitária, possibilitou uma especialização na limpeza urbana, voltada propriamente para os resíduos. 
A terceira ação, sinalizaram Aizen \& Pechman (1985), foi à criação, em 1865, de um vazadouro para os resíduos fora da cidade, na Ilha de Sapucaia, na Ilha do Governador ${ }^{10}$.

Com a escolha deste local para a disposição dos resíduos aproveitou-se da estrutura já existente, assim os resíduos, sem os excrementos eram transportados até as pontes e de lá, por meio de barcaças, até a Ilha de Sapucaia. Ainda segundo os autores, próximo às pontes também foram construídos armazéns para concentrar os resíduos antes que fossem embarcados.

Para Machado (2013), a criação de uma localidade para vazadouro de resíduos fora considerada à época, a solução, todavia, os problemas na cidade continuavam, entre outros motivos, porque as pessoas faziam o despejo aleatório dos resíduos e porque diante do mau tempo na Baía de Guanabara não havia a possibilidade de transportar os resíduos para o vazadouro na Ilha de Sapucaia, que ficavam amontoados nos armazéns e nas pontes espalhadas pela cidade, o que gerava muita reclamação da população.

Diante desta realidade foram construídos vazadouros, tanto nos subúrbios como na Zona Sul.

Em 1876, afirmaram Queiroz e Marafon, Aleixo Gary ${ }^{11}$ (2015), o francês radicado no Brasil desde 1859, fora contratado pelo Ministério dos Negócios do Império para administração e execução de parte do serviço de limpeza urbana.

Nesse período, a cidade teve melhorias nos serviços. Todavia, a limpeza das praias e o transporte até a ilha de Sapucaia, que era realizado por outras empresas, apresentavam falhas operacionais, o que na ótica de Gary impedia a melhoria dos serviços de limpeza urbana.

Gary propôs concentrar todo o conjunto de atividades de limpeza, remoção e transporte dos resíduos, mas não obteve sucesso. Com a recusa do governo, Gary ficou responsável pela limpeza dos logradouros da maior parte da cidade e pelo transporte do resíduo à Ilha da Sapucaia, até o ano de 1891, alguns anos após o término do contrato de concessão que teria a duração de 10 anos.

\footnotetext{
${ }^{10}$ A criação de territórios resíduos nas localidades de população de baixa renda demonstra que os interesses econômicos impõe uma dinâmica de injustiças sociais.

${ }^{11}$ Gary inaugurou uma nova era na história da limpeza pública no Rio Janeiro, a sua influência pode ser percebida pela forma como são chamados na atualidade os operadores de limpeza urbana "gari".
} 
Eigenheer (2009) observou que a questão da disposição dos resíduos configurava-se no final do século XIX como a mais problemática, e, assim, o modelo de incineração surgiu como a solução para o problema, mas havia polêmicas quanto à localização e ao modelo a ser adotado, ou seja, se deveria construir vários fornos ou apenas um. Em 1895, a proposta inicial de apenas um forno saiu vitoriosa e começou a construção do forno de incineração de Manguinhos, que, posteriormente, não funcionou a contento e foi desativado.

A questão sanitária da cidade do Rio de Janeiro havia melhorado com a instalação da rede de esgotos da City Improvements, tendo em vista que tinha acabado com o lançamento do esgoto in natura nas valas e no mar. Todavia, não solucionou o problema, o que desencadeava constantes epidemias de febre amarela, peste bubônica e varíola e, consequentemente, a morte de milhares de pessoas anualmente. Aliado ao problema de esgoto permanecia os dilemas sobre a limpeza urbana da cidade.

De acordo com Queiroz e Marafon (2015), no ano de 1902 o presidente Rodrigues Alves, representante da oligarquia paulista do café, nomeou o engenheiro Francisco Franco Pereira Passos prefeito da cidade do Rio de Janeiro com a missão de promover a sua modernização.

O prefeito Pereira Passos modernizou o Porto e realizou uma ampla reforma urbana, com ênfase no saneamento, na reestruturação viária, no embelezamento da cidade e no combate as epidemias.

Nesse processo, promoveu as demolições conhecidas popularmente como a política do "bota-abaixo" e a Revolta da Vacina ${ }^{12}$, projeto dirigido pelo médico e sanitarista Oswaldo Cruz, diretor do Serviço de Saúde Pública.

Conforme sinalizou Machado (2013), a reforma serviu como a maior força segregadora que já havia atingido a cidade. Por um lado, expulsando a população pobre e trabalhadora, que ficou sem a moradia por causa da destruição dos cortiços, e por outro lado, favorecendo a burguesa emergente que viu seus imóveis valorizados, os bancos que lucraram com o Estado no financiamento das

\footnotetext{
${ }^{12}$ A Revolta da Vacina foi uma campanha de vacinação obrigatória colocada em prática em novembro de 1904 de forma violenta e autoritária. Em alguns casos, os agentes sanitários invadiam as casas e vacinavam as pessoas à força, provocando revolta da população. BENCHIMOL, Jaime Larry. Pereira Passos: um Haussmann tropical: A renovação urbana da cidade do Rio de Janeiro no início do século XX. Rio de Janeiro: Secretaria Municipal de Cultura, Turismo e Esportes, Departamento de Documentação e Informação Cultural, 1990.
} 
desapropriações e obras, e o grande capital que adquiriam terrenos nas áreas valorizadas.

Machado (2013) destacou que com a nova reconfiguração urbana, na Zona Sul, no Centro do Rio de Janeiro e em parte da Zona Norte, os resíduos eram coletados de forma regular e destinados ao vazadouro da Ilha de Sapucaia, mas as áreas suburbanas, que já eram carentes desses serviços viram a sua situação agravada com a proliferação dos vazadouros clandestinos, em particular em Benfica, Cascadura, Manguinhos e Olaria.

Segundo Mesquita Jr (2004) como a qualidade dos serviços de limpeza urbana não atendia a demanda, a ideia de construção de sistemas de incineração foi retomada, destacando a necessidade de se conhecer a composição dos resíduos para adequação do forno a ser adotado, originando assim a análise gravimétrica, química e física dos resíduos como instrumento de planejamento.

$\mathrm{O}$ autor afirmou que devido à dificuldade de navegação em torno da Ilha da Sapucaia, causada pelo acúmulo de resíduos, em 1922, a Prefeitura contratou a empresa Shimidt Trost \& Cia para construir um incinerador na Ilha da Sapucaia, que seria entregue pela empresa à Prefeitura após trinta anos de uso, o que também não vingou.

Em 1925, o então Prefeito Alaor Prata fez uma nova tentativa, mas a usina não chegou a ser construída em função dos protestos da vizinhança.

Dando continuidade, afirmou que, em 1927, o prefeito do Rio de Janeiro, Antônio Prado Júnior, contratou o urbanista francês Alfred Agache para elaborar o Plano de remodelação, extensão e embelezamento da capital. O projeto conhecido como Plano Agache pretendia organizar o crescimento do Rio de Janeiro, determinando áreas de expansão, prevendo a criação de redes de serviço e tratando da instalação da infraestrutura urbana da capital.

Mesquita Jr (2004) destacou que Agache analisando as vantagens e desvantagens da incineração para a cidade, concluiu pela inviabilidade da sua implantação, principalmente pelo fato da disposição final no vazadouro da Ilha de Sapucaia ser muito próximo ao bairro do Caju, que já era um bairro industrializado e com grande número de população.

O vazadouro da Ilha de Sapucaia continuou sendo a solução para a disposição final dos resíduos até 1940, quando o Prefeito Henrique Dodsworth promoveu grande reforma nos serviços de limpeza urbana e encerrou o despejo de 
resíduos na Ilha de Sapucaia, construindo um novo vazadouro na Praia do Retiro Saudoso e Parada do Amorim na ponta do Caju, que se tornou o principal território dos resíduos.

É importante destacar que, em 1945, com o Pós Segunda Guerra, num contexto de avanços tecnológicos e de novos padrões de consumo, as preocupações sobre resíduos sólidos ganharam ênfase na Europa, em particular na Alemanha, mas ainda era centrada na disposição final, sem grandes questionamentos do processo produtivo, o que perdurou até o início da década de 1970.

Demajorovic (1994) enfatizou que foi a partir da Conferência de Estocolmo, realizada na Suécia, em 1972, quando as questões ambientais ascenderam à agenda contemporânea, que os debates sobre os resíduos sólidos urbanos ganharam força com a identificação da destruição da camada de ozônio devido à emissão de gás carbônico, com os impactos sobre a vida marinha em função da disposição de resíduos líquidos e sólidos nos mares e rios e com a contaminação dos lençóis de água subterrâneos, decorrentes da disposição em aterros não controlados.

O contexto de aumento vertiginoso dos impactos ambientais assinalou Demajorovic (1994), estimulou o reexame dos problemas relacionados aos fenômenos das externalidades. Para ele, o modelo da balança de materiais, partindo da lei da conservação da matéria, permitiu incorporar novas variáveis dentro do conceito de externalidades através de uma compreensão mais efetiva do papel dos resíduos no sistema econômico.

Esse modelo colocou dentro da análise econômica a variável ambiental no mesmo patamar de importância de variáveis tradicionais como investimento, renda, salário e lucro, substituindo o modelo econômico fechado tradicional por um modelo de economia termodinamicamente aberto, na qual o meio ambiente passou a desempenhar um papel fundamental no processo produtivo e, portanto, os custos externos relacionados à disposição de resíduos, mais do que uma mera curiosidade teórica, passaram a representar um fator essencial dentro do processo econômico.

Assim, aliado a outros condicionantes como o aumento da mobilização dos grupos ambientalistas, a partir de 1975 os países da Organização para a Cooperação e Desenvolvimento Econômico - OCDE alteraram o modelo de 
gestão de resíduos sólidos centrado na disposição final e estabeleceram novas prioridades em nível internacional (Demajorovic, 1994).

Com a nova configuração, a reciclagem dos materiais, a incineração com reaproveitamento de energia e a disposição de resíduos em aterros sanitários controlados tornaram-se metas prioritárias na política de gestão de resíduos.

Na década seguinte, como desdobramento destas prioridades se desenvolveu um mercado rentável da reciclagem. Ainda de acordo com esse autor, os efeitos na prática sobre a gestão de resíduos sólidos se acentuaram parcialmente, com a promoção da recuperação e da reciclagem dos materiais, inclusive com o desenvolvimento de uma legislação estimulando o uso de produtos reciclados, entretanto a redução na produção de resíduos continuava ínfima.

Ainda na década de 1980, afirmou Demajorovic (1994) surgiu uma nova primazia em relação à gestão de resíduos sólidos nos países desenvolvidos, qual seja a diminuição na produção de determinados produtos. Desse modo, a prioridade passou a ser a redução do volume de resíduos no início do processo produtivo, tendo os fabricantes à responsabilidade pelo tratamento e disposição final dos resíduos difíceis de serem reciclados.

Demajorovic et al. (2007) argumentam que o debate ambiental no Brasil ganhou mais força, com a vitória de representantes do movimento ambientalista na retomada das eleições legislativas livres em 1982 e, principalmente, com a Constituição Federal de 1988, lei maior do ordenamento jurídico brasileiro, que definiu o meio ambiente como um bem de uso comum do povo e essencial à sadia qualidade de vida, impondo ao poder público e à coletividade o dever de defendêlo e preservá-lo para as presentes e as futuras gerações, tendo vista ser um pressuposto para concretização do princípio da dignidade da pessoa humana.

É nesse contexto, destacaram Jacobi et. al. (1997), que ocorreram as experiências inovadoras na gestão dos resíduos sólidos, que articularam práticas governamentais com organizações comunitárias, cooperativas e associações de catadores de materiais recicláveis em São Paulo, em Porto Alegre e em Belo Horizonte.

Eles ressaltaram que, mesmo em condições frágeis, os catadores e as catadoras de materiais recicláveis passaram a integrar o sistema de gerenciamento de resíduos sólidos nos municípios citados, abrindo uma nova perspectiva para a 
relação do poder municipal com os grupos organizados de catadores e catadoras, criando condições favoráveis para a inclusão social dos segmentos estigmatizados.

Entretanto, Jacobi, et al. (2011), enfatizaram que a preocupação mundial com a geração excessiva e a disposição final inadequada dos resíduos sólidos viraram prioridades a partir da Conferência das Nações Unidas sobre Meio Ambiente e Desenvolvimento - a Rio 92, tanto nos países ricos quanto nos mais pobres, por contribuir com o aquecimento global e com as mudanças do clima na Terra.

Eles argumentaram que, na Conferência Rio 92, estabeleceu-se que o manejo ambientalmente saudável dos resíduos se encontrava entre as questões mais importantes para a manutenção da qualidade do meio ambiente da Terra e, principalmente, para alcançar um desenvolvimento ambientalmente saudável em todos os países.

Apesar da importância demonstrada na Conferência Rio 92, a questão dos resíduos não apareceu de forma central na Declaração do Milênio e nas Conferências Rio+10 e Rio+20, só recebendo novamente uma atenção especial no documento produzido em 2015, pela Organização das Nações Unidas intitulado “Transformando Nosso Mundo: A Agenda 2030 para o Desenvolvimento Sustentável", composta por 17 Objetivos de Desenvolvimento Sustentável e 169 metas, a serem consolidados até o ano de 2030.

Nesse contexto, mereceu destaque o $6^{\circ}$ objetivo da ODS que visa assegurar a disponibilidade e a gestão sustentável da água e do saneamento para todos e o $12^{\circ}$ que objetiva assegurar padrões de produção e de consumo sustentáveis, cuja meta 12.5 estabeleceu a necessidade de diminuir substancialmente, até 2030, a geração de resíduos por meio de prevenção, redução, reciclagem e reuso.

A despeito da extrema relevância do ponto de vista ambiental, social, econômico, cultural e de saúde pública, a discussão em torno dos resíduos sólidos no Brasil até meados da década de 1980 era incipiente, em contraste com a Europa e os Estados Unidos.

Os trabalhos produzidos por Costa (1983), apresentando a história da limpeza pública na cidade de Porto Alegre, por Aizen e Pechmann (1985), descrevendo a memória da limpeza urbana do Rio de Janeiro, por Lima (1988), analisando a reciclagem como alternativa para os catadores e as catadoras de resíduos em Recife, e por Eigenheer (1989), na qual numa perspectiva histórica, 
demonstrou como tem sido enfrentado o problema dos resíduos foram inspiradores nesse campo e influenciaram pesquisas posteriores.

Após a Conferência Rio 92 houve um grande crescimento das pesquisas científicas em relação aos resíduos sólidos, com a produção de artigos, monografias, dissertações e teses. As abordagens versaram sobre os mais variados campos de conhecimento, recortes teóricos e metodológicos e matrizes políticas e ideológicas.

Foram produzidos trabalhos enfatizando o aparato técnico e operacional da gestão dos resíduos sólidos urbanos, com ênfase nos impactos da disposição inadequada dos resíduos no solo, assim como sobre os aspectos financeiros e de planejamento da gestão dos resíduos. Nesse grupo, destacamos o trabalho realizado pelo Compromisso Empresarial para Reciclagem - CEMPRE e pelo Instituto de Pesquisas Tecnológicas - IPT intitulado "Lixo Municipal: Manual de Gerenciamento Integrado" (1995).

Dividido em cinco capítulos, a saber: o gerenciamento integrado do lixo municipal, a origem e composição do lixo, os serviços de limpeza, a disposição final do lixo e o tratamento e três anexos, sendo o primeiro sobre a legislação, o segundo sobre as normas e o terceiro com a relação das entidades e das associações, o manual do CEMPRE/IPT objetivava contribuir com informações para o gerenciamento dos resíduos municipais e para a implantação de políticas públicas, a fim de se estabelecer as melhores formas de destinação e de disposição finais de resíduos, em particular sobre a coleta seletiva, a reciclagem e os aterros sanitários.

O manual reconheceu a gravidade do quadro geral sobre os resíduos no Brasil e a competência municipal nos sistemas de limpeza urbana, na destinação e na disposição final dos resíduos. Reconheceu também as limitações de ordem orçamentária e financeira, técnica e profissional dos municípios e a descontinuidade política e administrativa, bem como a ausência de controle ambiental. Foi ainda reconhecido que o Gerenciamento Integrado de Resíduos Sólidos Urbanos se traduzia no envolvimento de diferentes entes da administração pública e da sociedade civil e das particularidades demográficas, climáticas e urbanísticas de cada município, articulando ações institucionais, legais, técnicas, financeiras, de planejamento e gerencial, com base em critérios sanitários, 
ambientais e econômicos, para coletar, segregar, tratar e dispor os resíduos municipais.

Essa perspectiva, entretanto, não questionava os valores culturais da sociedade de consumo e os aspectos políticos, sociais, culturais e econômicos da questão dos resíduos, isto é, não problematizava o sistema hegemônico vigente e os condicionantes estruturais do modo de produção e de consumo dominantes e os limites impostos pelo mercado.

Na década de 1990, quando a reciclagem no Brasil ganhava espaço no poder público com políticas direcionadas a este segmento, na mídia e na sociedade de forma geral, surgiu uma abordagem crítica demonstrando as suas limitações, em particular sobre a redução do volume de resíduos e do consumo de energia, tendo em vista que o processo de reciclagem necessita de matérias-primas e energia consideráveis, além de também produzir resíduos.

Nesta linha, Montibeller Filho (1994) em sua análise sobre a economia da reciclagem e a sua importância ambiental mostrou que para os economistas neoclássicos, os quais consideram o rejeito uma externalidade negativa do processo produtivo, a economia da reciclagem aparecia como uma forma de solucionar os problemas da poluição ambiental e como o "futuro" da "crise ecológica".

Essa abordagem de grande relevância evidenciou a limitação do ponto de vista econômico e ambiental do processo de reciclagem. Contudo tem a fragilidade de se limitar a analisar a reciclagem enquanto processo de transformação de uma mercadoria usada em uma nova, sem se atentar para a dimensão social do processo, ou seja, de geração de trabalho, renda, construção identitária e produção de cidadania aos sujeitos sociais vulneráveis e incluídos precariamente.

Layrargues (2002) retomou essa discussão de forma mais aprofundada ao analisar o significado ideológico da reciclagem da lata de alumínio e suas implicações para a educação ambiental.

Para ele, o discurso ecológico oficial em torno da reciclagem, que enfatiza a economia dos recursos naturais e de energia elétrica, a diminuição do volume dos resíduos nos depósitos de resíduos e a geração de renda pelos catadores e catadoras e sucateiros apresenta um "cinismo" e camuflava a sua verdadeira intenção, a articulação entre os interesses da proteção ambiental com os da 
economia, via mercado, considerados antagônicos até a formulação do conceito de desenvolvimento sustentável.

\begin{abstract}
Não que os argumentos ambientais sejam falsos, eles simplesmente mascaram o interesse da indústria de reciclagem em promover a reciclagem de alumínio, utilizando-se como justificativa a associação dessa prática à melhoria da qualidade ambiental. Cria-se a ilusão de que a prática ecologicamente correta da reciclagem contribuirá para a resolução de um problema ambiental. Com a falsa segurança e alienação da realidade, obtém-se a possibilidade de uma parceria do mercado com a sociedade, na qual o mais importante para a indústria de latas de alumínio é a garantia de obtenção da matéria-prima que não passe pelo atravessador e dispense $95 \%$ do custo energético para a fabricação do produto. É verdade que o meio ambiente também é beneficiado através da reciclagem das latas de alumínio, mas nesse caso o fator determinante é a redução do custo da empresa (LAYRARGUES, 2002, p. 16).
\end{abstract}

Layrargues (2002) não se posicionou, todavia, contrário à reciclagem. Ele apenas elucidou que para enfrentar a questão dos resíduos sólidos fazia-se necessário adotar medidas técnicas, mas, sobretudo, discutir as suas dimensões política, econômica, social e cultural, objetivando construir políticas públicas de gestão de resíduos sólidos, incluindo a reciclagem e a coleta seletiva, com inclusão social dos grupos sociais marginalizados.

Nessa mesma direção Silva (2011) afirmou que a indústria da reciclagem é extremamente lucrativa e integra a produção globalizada, controlada pelos grandes grupos econômicos, que determinam os valores dos produtos reciclados. Assim, a propalada sustentabilidade ambiental encontra-se totalmente desvinculada da sustentabilidade social, tendo em vista que mobiliza os trabalhadores num processo de exploração, de informalidade e de ausência de vínculos trabalhistas e previdenciários e da precariedade nas condições trabalho e de vida.

Numa visão crítica às gestões estritamente tecnicistas, que desconsideram as precárias condições de trabalho, riscos ocupacionais e processos de vulnerabilidade dos catadores e das catadoras de materiais recicláveis, bem como o papel central desses sujeitos sociais no sistema de gerenciamento de resíduos sólidos foram elaboradas abordagens socioambientais, focadas nos princípios da redução, da reutilização e da reciclagem, na responsabilidade do gerador dos resíduos e na participação social na gestão pública compartilhada dos resíduos, 
especialmente das organizações de catadores nos programas municipais de coleta seletiva.

Nessa ótica se inseriu o trabalho de Jacobi et. al. (1997), intitulado a "Criação do Capital Social: o caso ASMARE - Associação dos Catadores de Papel, Papelão e Material Reaproveitável de Belo Horizonte" que abordou o surgimento de uma forma organizativa de resistência dos catadores e das catadoras de materiais recicláveis na busca de identidade coletiva, diante de uma realidade de inclusão social subalterna.

Nessa análise, ficou evidente, a relevância da união de três segmentos sociais, quais sejam: a Pastoral de Rua da Igreja Católica, os Catadores de Papel e o Poder Público, no município de Belo Horizonte, para o resgate da cidadania, para a melhoria das condições de trabalho e vida desse grupo historicamente marginalizado, bem como para o reconhecimento da centralidade dos catadores e das catadoras na gestão dos programas de coleta seletiva de materiais recicláveis.

Para os autores, essa reconfiguração objetivava reduzir as vulnerabilidades dos catadores e das catadoras e maximizar benefícios econômicos, ambientais e sociais, por meio de uma iniciativa que privilegia a inclusão social e a geração de trabalho para a população de baixa renda. Além disso, o reconhecimento dos catadores e das catadoras como sujeitos centrais na coleta seletiva inovou e criou condições para que o Estado os incorporasse no processo de gestão, rompendo assim com a lógica do mercado.

Na segunda metade da década de 1990 muitos trabalhos foram direcionados a analisar a situação aos quais estavam submetidos os catadores e as catadoras de materiais recicláveis que, em linhas gerais, se evidenciava odesemprego, instabilidade, informalidade, ausência de perspectivas, precarização do trabalho, isolamento social e estigmatização.

Essa realidade conduziu muitos autores a problematizar se os catadores e as catadoras estavam diante de um processo de exclusão (Araújo, 1997) ou se esse segmento excedente era inserido de forma subalterna, através da própria atividade, na lógica de acumulação capitalista.

Outra abordagem importante foi apontada Porto et. al. (2004). Segundo os autores, no final dos anos de 1990 e início dos anos 2000, os trabalhos relacionando à questão dos resíduos sólidos e à saúde pública eram embrionários, sendo que as poucas exceções se restringiam a falar sobre impactos gerais ou 
específicos dos resíduos sobre a saúde dos trabalhadores do serviço de coleta, entretanto sem grandes aprofundamentos.

Porto et al. (2004) no artigo intitulado "Lixo, trabalho e saúde: um estudo de caso com catadores em um aterro metropolitano no Rio de Janeiro, Brasil" apresentaram uma reflexão sobre as condições de vida, trabalho e saúde envolvendo 218 catadores e catadoras de materiais recicláveis atuando no aterro metropolitano do Rio de Janeiro, Brasil, enfatizando os riscos ocupacionais e ambientais em contextos de vulnerabilidade.

A partir das percepções dos sujeitos sociais acerca de suas condições de vida, trabalho e saúde, os autores evidenciaram que estes percebiam os resíduos como fonte de sobrevivência e a saúde como capacidade para o trabalho, tendendo dessa forma a negar a relação direta entre o trabalho e problemas de saúde. Entretanto, afirmavam que os riscos levantados e a morbidade referida apontavam para a elevada insalubridade e periculosidade.

Essa fecunda e inovadora análise, que vinculou o campo da saúde do trabalhador à temática ambiental, sugeriu a construção de políticas públicas que integrassem diferentes dimensões do problema, como inclusão social, preservação ambiental, saúde pública e o resgate da dignidade desses trabalhadores.

Partindo de uma visão que problematizava os diferentes significados que os resíduos e os catadores e catadoras têm assumido em nossa sociedade, Juncá (2004) investigou em sua tese de doutorado as táticas de resistência adotadas por esses sujeitos diante de um processo perverso de filiação.

A autora concluiu que a resistência às ambiguidades e a construção de outro modo de vida encontravam-se intimamente interligadas à criação de formas alternativas de trabalho com os resíduos, por meio de movimentos de organização dos catadores e catadoras, caminhando na direção da constituição de uma identidade profissional, portanto, para um processo de filiação social centrado na cidadania.

Demajorovic et. al. (2007), ao analisarem um conjunto de programas de gestão compartilhada de resíduos sólidos no Brasil afirmaram que, apesar dessas iniciativas de gestão pública, baseadas na integração entre o poder público e as organizações de catadores e de catadoras na gestão dos programas de coleta seletiva de materiais recicláveis, representarem um avanço no sentido de buscar maximizar benefícios econômicos, ambientais e sociais, por meio de uma 
iniciativa que privilegia a inclusão social e a geração de trabalho para a população de baixa renda, elas não se tornaram sustentáveis na medida em que encontraram um conjunto de desafios e de vulnerabilidades. Entre os principais desafios destacaram o aumento do interesse por diversos segmentos sociais pelos resíduos, o crescimento substancial do quantitativo de catadores e de catadoras, problemas ligados à administração municipal e a organização interna das cooperativas de catadores e de catadoras.

Besen (2011), em sua tese de doutorado intitulada "Coleta seletiva com inclusão de catadores: construção participativa de indicadores e índices de sustentabilidade" constatou que, em 2010, mesmo diante dos investimentos do governo federal em projetos para a implantação da coleta seletiva e o fortalecimento das organizações de catadores e de catadoras de materiais recicláveis, as administrações municipais enfrentavam dificuldades técnicas, administrativas e financeiras para prestar o serviço de coleta seletiva de forma universalizada e eficiente, particularmente por meio das organizações de catadores e catadoras de materiais recicláveis.

Para Besen (2011), a produção acadêmica sobre a temática não identificou indicadores de sustentabilidade validados de forma participativa, tanto para a coleta seletiva quanto para a organização dos catadores e das catadoras de materiais recicláveis, o que significou uma fragilidade tendo em vista que esta metodologia poderia ser um instrumento relevante para planejar, gerenciar, monitorar, propor metas e alternativas de gestão, além de poder apoiar a elaboração de políticas públicas e o direcionamento de investimentos.

Nesse contexto de fragilidade institucional da coleta seletiva, Besen (2011) identificou, construiu e validou de forma participativa, com os principais sujeitos envolvidos na gestão dos resíduos, indicadores e índices de sustentabilidade para gestão, avaliação e monitoramento, com o objetivo de fortalecer a sua inserção nos sistemas municipais de resíduos sólidos e sua interface com a inclusão social e a saúde pública.

Buda (2014), em sua tese intitulada "Política Nacional de Resíduos Sólidos: efeito nas condições e ambiente de trabalho das cooperativas de catadores conveniadas com a prefeitura do município de São Paulo" avaliou os efeitos causados pela PNRS nas condições e no ambiente de trabalho das cooperativas e 
nas mudanças ocorridas nas relações com as empresas, com os órgãos municipais e com a sociedade quanto ao volume e qualidade dos resíduos recebidos.

Para o autor, a PNRS se configurou como modeladora de novos paradigmas sociais, dentre os quais destacou os princípios de responsabilidade social compartilhada e da logística reversa. Além desse aspecto, enfatizou que as cooperativas de catadores de material reciclável desempenham um papel importante, não somente nas questões ambientais, mas também por ser responsável pela inclusão social dos cidadãos de baixa renda.

Ele concluiu que a Política Nacional de Resíduos Sólidos não cumpriu seu papel plenamente e que pouco tem avançado junto às cooperativas de catadores e catadoras conveniadas com a prefeitura do município de São Paulo. Nesse contexto, afirmou que as mudanças comportamentais pretendidas pelo documento legal não deverão ser obtidas de forma rápida, mas sim gradualmente, e que a aceleração desse processo somente ocorrerá com o incremento da fiscalização e do apoio do poder público à questão da reciclagem.

Almeida et al. (2013), ao discutirem no trabalho "Protagonismo e Esfera Pública em Campos dos Goytacazes: a trajetória recente dos catadores do lixão da Codin", destacaram que os catadores e as catadoras de recicláveis, amparados pela promulgação ainda que tardia da PNRS retornaram à cena acadêmica e das políticas públicas reivindicando um novo lugar na atual cadeia da reciclagem.

Segundo as autoras, preocupados com o fim da atividade de catação de recicláveis no lixão Codin e sem alternativa concreta de inclusão socioeconômica, os catadores e as catadoras se mobilizaram em torno de três reivindicações, a saber: a integração produtiva nos moldes anunciados pela nova PNRS (2010), a proteção social dos catadores e catadoras e a indenização pelos serviços prestados ao município como catadores de recicláveis. No entanto, argumentou as autoras, como resposta às revindicações, o poder público adotou medidas autoritárias, aliadas a políticas compensatórias e à contratação dos trabalhadores, especialmente das lideranças do conselho, para cooptá-los e para enfraquecer o movimento de resistência.

Elas prosseguem afirmando que a tomada de consciência dos trabalhadores só foi possível pelo reconhecimento de sua identidade como trabalhador (a) e como catador (a) e que o sentimento de injustiça que tomou conta dos catadores e catadoras foi à motivação responsável por sua organização e por sua participação 
política coletiva na construção de respostas menos injustas e que pudessem reparar a situação a qual foram submetidos. Todavia, destacaram dois instrumentos de apoio fundamentais para a construção desse novo sujeito político, a parceria com a UFF Campos e do MNCR e a promulgação da Lei 12.305/10.

Almeida et al. (2013) finalizaram afirmando que o recente protagonismo dos catadores e catadoras, bem como a organização política por uma agenda pública includente dos grupos subalternos até então marginalizados e estigmatizados, só foi possível com a consciência política desse grupo sobre os seus dramas sociais.

O IPEA, instituição que tem promovido diversas pesquisas sobre a situação social dos catadores e das catadoras de material reciclável, em 2016, coordenou a elaboração do livro "Catadores de Materiais Recicláveis: um encontro nacional" oferecendo bases para a atuação do poder público e para o fortalecimento da luta dos catadores e das catadoras por uma inserção mais digna, em oposição ao quadro de inclusão precária na estrutura social.

A coletânea teve uma apresentação do presidente do IPEA, Josué de Souza, um prefácio do Gilberto Carvalho, um dos interlocutores do governo federal com o MNCR, uma introdução realizada por Pereira e Goes, além de 23 trabalhos, subdivididos em 4 partes.

A primeira parte composta por um único artigo relacionado à reciclagem e a inclusão social no Brasil, a segunda parte composta por 07 artigos discutindo a Identidade: construção de gênero, raça e trabalho, a terceira composta por 8 trabalhos tratando da organização e do fortalecimento coletivo dos catadores e catadoras e a quarta parte, composta por 7 artigos, relacionada ao desenvolvimento da técnica, da tecnologia e da inovação na cadeia produtiva de reciclagem popular.

Iniciaram a coletânea com o artigo produzido por Sant'Ana e Metello intitulado "Reciclagem e inclusão social no Brasil: balanço e desafios" (2016), na qual abordaram a trajetória do relacionamento entre o MNCR, movimento que se consolidou como um dos principais interlocutores da pauta do inclusão participativa dos catadores e das catadoras de materiais recicláveis nas políticas sociais no país e o governo federal, por meio de normas jurídicas e de programas governamentais de apoio aos catadores e as catadoras de materiais recicláveis, com a destinação de infraestrutura para que estes segmento tenha condições de prestar os serviços a que se propõem. 
Sant'ana e Metello (2016) destacaram a importância do MNCR para a entrada do tema da reciclagem com inclusão social na agenda política do país. Para os autores, antes da consolidação do MNCR a representação simbólica e efetiva das demandas dos catadores e das catadoras de materiais recicláveis era realizada por meio do engajamento das organizações de apoio, que buscavam alertar as instituições públicas para a alta relevância social do tema, mas a partir da criação do MNCR essa representação se tornou mais forte e possibilitou a expressão das demandas dos catadores e catadoras pelos próprios sujeitos.

Apesar dos avanços obtidos, Sant’ana e Metello (2016) destacaram que a continuidade da trajetória virtuosa dependerá de saltos estruturais e de grande impacto sobre o setor de reciclagem. Para tanto, defenderam um caminho que passa pelo empenho governamental em diversas ações, entre elas a promoção da contratação formal das cooperativas no sistema de coleta seletiva formal, o incentivo ao acordo setorial de embalagens e eletrônicos, com intensa participação dos catadores e das catadoras, a promoção da cadeia industrial da reciclagem e o aproveitamento das oportunidades geradas pela expansão da reciclagem do resíduo eletrônico.

Cherfem, em seu artigo "Relações de gênero e raça em uma cooperativa de resíduos sólidos: desafios de um setor" (2016), na qual analisou diferentes empreendimentos de economia solidária que visam construir uma proposta de geração de renda para uma população excluída do mercado de trabalho, buscou compreender como as diferentes formas de dominação que estruturam a sociedade, entre elas, classe, raça e gênero relacionam-se no mundo do trabalho e influenciam a organização laboral de uma cooperativa de reciclagem localizada na região de Campinas, em São Paulo.

Ela enfatizou que a grande quantidade de mulheres nesses empreendimentos solidários foi decorrente das altas taxas de desemprego nos anos 1990 e no início dos 2000 e que, mesmo diante do cenário brasileiro de avanços após os anos 2000, com a redução de desigualdades sociais, ainda persistem padrões diferenciados de participação na educação e no mercado de trabalho que afetam de forma específica as mulheres negras, o que pôde ser revelado no âmbito dos empreendimentos de economia solidária.

Cherfem (2016) também enfatizou que a condição precária de trabalho das cooperativas está intimamente relacionada à grande quantidade de mulheres no 
setor, especialmente de mulheres negras, o que indicou a existência de uma feminização e de uma racialização do setor.

Costa e Pato no artigo "A constituição de catadores de material reciclável: a identidade estigmatizada pela exclusão e a construção da emancipação como forma de transcendência" (2016), investigaram como os catadores e as catadoras de materiais recicláveis das cooperativas de Taguatinga e Águas Claras, regiões administrativas (RAs) do Distrito Federal (DF) construíram sua identidade social, assinalando a premência da percepção da exclusão e a existência de utopias emancipatórias, calcadas na transformação pessoal e socioambiental.

Elas tentaram compreender, com apoio na hermenêutica, como os catadores e as catadoras de materiais recicláveis da cooperativa "Reciclo" interpretam sua condição de trabalhadores ambientais a partir de suas histórias de vida e da constituição da cooperativa. Para tanto, utilizaram o método biográfico na modalidade história de vida e realizaram entrevistas semiestruturadas, análise documental e o diário de campo.

Segundo Costa e Pato (2016), a pesquisa confirmou os processos de exclusão em que os catadores e as catadoras estavam submetidos, particularmente no que tange a segregação, a ausência do direito à cidadania e a negação da própria dimensão humana. Citam como exemplo desses processos o trabalho infantil e suas consequências, as condições de extrema miséria em que viviam os pais dos catadores e catadoras e o abandono da escola, no sentido de não conseguirem se adaptar às estruturas dessa instituição, devido ao contexto de situação social vivenciada.

As autoras destacaram que a organização desses catadores e catadoras e a tomada da conscientização da realidade e da identidade ligada à exclusão foram fundamentais à construção de uma identidade emancipatória e ambiental. Enfatizaram que um dos processos centrais na construção da emancipação foi a percepção do catador como agentes ambientais e sujeitos ecológicos, capazes de contribuir para minimizar a problemática dos resíduos sólidos, bem como transformar suas vidas e a organização coletiva, instituindo assim uma luta incessante pela transformação da realidade, tanto no nível pessoal como socioambiental.

Wirth e Oliveira no trabalho "A Política Nacional de Resíduos Sólidos e os modelos de gestão" (2016), fizeram um breve resgate do serviço público de 
limpeza urbana no Brasil, identificando os períodos de implantação, estatização e privatização dos serviços e os modelos de gestão existentes neste processo. Além disso, enfatizaram o campo de forças sociais presentes na questão dos resíduos sólidos e analisaram dois municípios gaúchos, com foco na forma como cada modelo assimilava o trabalho autogestionário dos catadores e das catadoras de materiais recicláveis.

Os autores evidenciaram que nos países europeus e nos Estados Unidos, tomados como referência para a elaboração das políticas de resíduos sólidos, o movimento ambiental, o setor empresarial e o setor público são os principais atores identificados na arena e nas discussões políticas. Entretanto, no Brasil, há um novo ator social, o Movimento Nacional dos Catadores de Materiais Recicláveis (MNCR), segmento que contribuiu para evidenciar interesses antagônicos presentes na gestão deste serviço público em um contexto em que as práticas municipais de manejo dos resíduos sólidos estão contaminadas por interesses privados, onde o controle social sobre a prestação deste serviço público é quase inexistente.

Wirth e Oliveira (2016) destacaram que a PNRS possui o potencial de reconfigurar às práticas de gestão, à medida que introduziu uma série de conceitos e obrigações a partir de uma visão abrangente e integrada da questão dos resíduos.

Em primeiro lugar, de acordo com os autores, não trata os resíduos como externalidade. Em segundo, embora a disposição final seja um ponto central na política, a PNRS apontou que o problema deve se iniciar pela não geração, passando pela redução, reaproveitamento, reciclagem, tratamento e, por último, a disposição final ambientalmente adequada dos rejeitos.

Nessa perspectiva, ela inseriu a responsabilidade compartilhada pelo ciclo de vida dos produtos, a logística reversa e o princípio do poluidor-pagador, tornando o fabricante ou importador responsáveis por todo o ciclo de produção, incluindo o resíduo gerado pelo descarte da embalagem ou do próprio produto.

Em terceiro, impôs o princípio do direito da sociedade civil à informação e ao controle social. Em quarto, reconheceu o resíduo sólido reutilizável e reciclável como um bem econômico e de valor social, gerador de trabalho e renda e promotor de cidadania, sobretudo para os catadores e as catadoras de materiais recicláveis. Em quinto, reconheceu a importância dos catadores e das catadoras de materiais recicláveis como sujeitos sociais dos sistemas de gestão integrada de 
resíduos sólidos, ou seja, não mais como apêndice dos sistemas de limpeza urbana, mas como corresponsável na organização e execução desse serviço público.

A despeito desses avanços, os autores enfatizaram que o que tem ocorrido na prática, por uma grande parte dos municípios brasileiros, é a busca por efetivar uma manobra de adequação à PNRS de natureza estritamente retórica, reproduzindo o modelo de gestão privatista ou o modelo estatista, que não valorizam a dimensão social, portanto, os catadores e as catadoras de materiais recicláveis, o elo mais frágil da cadeia produtiva da reciclagem.

Lima e Souza, no trabalho "Bem público e interesses privados no tratamento do lixo urbano: o caso da parceria público-privada dos resíduos sólidos em Minas Gerais" (2016), iniciaram o texto mostrando a trajetória histórica dos catadores e das catadoras de materiais recicláveis, que é marcada por importantes transformações no que se refere ao reconhecimento da função social do trabalho que realizam e da sua organização.

Eles destacaram que os catadores e as catadoras de materiais recicláveis são os agentes econômicos mais numerosos na cadeia produtiva da reciclagem, entretanto, esse segmento apresenta três limitações importantes, a saber: a baixa remuneração, a precariedade da infraestrutura de coleta e triagem e a reduzida abrangência da coleta seletiva.

Os autores afirmaram que a PNRS estabeleceu o novo marco regulatório para a área de resíduos sólidos, impondo o reconhecimento do resíduo sólido reutilizável e reciclável como um bem econômico e de valor social, gerador de trabalho e renda e promotor de cidadania, o que pressupõe ações direcionadas à inclusão social e à emancipação econômica de catadores e catadoras de materiais recicláveis. Todavia, ressaltaram que esse arcabouço normativo não assegurou a proeminência na contratação dos catadores e das catadoras para realizar os serviços ambientais no sistema de gestão integrada de resíduos sólidos urbanos.

Afirmaram ainda que, nesse cenário de complexidade, ganhou força a incineração, a triagem mecanizada, além de arranjos organizacionais de consórcios intermunicipais e a contratação de serviços na modalidade de parcerias público-privadas (PPPs), orientações tecnológicas que incorporaram interesses econômicos privados em detrimento de interesses sociais coletivos. 
Os autores finalizaram o texto argumentando que diante da urgência criada pelo descompasso entre a falta de recursos e o prazo para dar uma destinação adequada ao resíduo, as prefeituras pragmaticamente se agarraram a soluções mágicas, sem se atentar para o modelo dirigido pelos catadores e catadoras de materiais recicláveis, que são mais eficiente ambientalmente, economicamente mais barato e mais justo socialmente.

No artigo "As experiências das diferentes formas de remuneração em associações e cooperativas de catadores de materiais recicláveis dos municípios da região metropolitana de Belo Horizonte: entre desafios e possibilidades na economia solidária”, Luttner et al (2016), abordaram as formas de remuneração exercidas em cooperativas e associações de catadores e de catadoras de materiais recicláveis, tendo em vista os princípios da economia solidária.

Para as autoras, as cooperativas de reciclagem, organizadas dentro dos princípios da economia solidária, cooperação, solidariedade e autogestão foram surgindo como uma alternativa de emprego, renda e inclusão profissional para um expressivo contingente de trabalhadores, num contexto de fortalecimento do debate sobre o meio ambiente, do aumento vertiginoso do "lixo" produzido nas cidades e da necessidade de atenuar os seus efeitos e também pela reestruturação econômica, determinada pela globalização da produção e dos mercados, que produziu milhares de desempregados e a precarização das relações de emprego e trabalho.

Inspiradas em estudos teóricos e conceituais dos empreendimentos de economia solidária, as autoras buscaram entendê-los em suas manifestações, dinâmicas e arranjos organizacionais internos, com o propósito de contribuir para o debate sobre os seus desafios e potencialidades.

Elas concluíram que embora possam expressar uma consciência ambiental em crescimento na sociedade e desempenhar papel fundamental na cadeia produtiva da reciclagem, as associações e as cooperativas de catadores de materiais recicláveis estudadas vivem dilemas e contradições, em particular por se inserir no mercado por meio de um tipo de organização de trabalho regido pelos princípios da economia solidária, como cooperação, solidariedade e autogestão, que se opõe à lógica capitalista nas questões referentes a desigualdades sociais e sustentabilidade socioambiental. 
O Instituto de Energia e Ambiente - IEE da Universidade de São Paulo e o Observatório da Política Nacional de Resíduos Sólidos - OPNRS, no âmbito do Acordo de Cooperação Técnica e Acadêmica, firmado em 31 de janeiro de 2017, por meio da Divisão de Ciência, Gestão e Tecnologia Ambiental - DCGCTA e do Instituto BVRio, representando o OPNRS decidiram após sete anos de vigência da Política Nacional de Resíduos Sólidos publicar o livro "Política Nacional de Resíduos Sólidos: Implementação e Monitoramento de Resíduos Sólidos” (2017).

Para tanto, convidaram Besen, Jacobi, Freitas para organizar a coletânea composta por dez artigos, com a finalidade criar condições para que a sociedade civil possa monitorar a implantação da PNRS e os resultados obtidos, assegurando que os princípios e objetivos da lei sejam cumpridos, além de gerar dados, informações e análises que promovam a transparência e qualifiquem os debates na sociedade.

A coletânea também proporcionará a visualização de um panorama nacional sobre os avanços, os desafios e as oportunidades para a implantação mais efetiva da Política Nacional de Resíduos Sólidos, para o aprimoramento de políticas públicas e a disseminação de instrumentos de monitoramento.

A coletânea foi iniciada com o artigo "Panorama da Implementação da Política Nacional de Resíduos Sólidos: resíduos urbanos” (2017), de autoria de Freitas, Besen e Jacobi, na qual apresentaram um panorama da implementação da PNRS, em relação aos resíduos sólidos urbanos, a partir da análise de indicadores do Sistema Nacional de Informação sobre Saneamento - Diagnóstico de Resíduos Sólidos, no período de 2010 a 2014, apontando para os avanços, os riscos e as fragilidades a serem superados diante da realidade dos resíduos no país. Além deste aspecto, sugeriram indicadores e fizeram recomendações, no intuito de apoiar a implantação e o monitoramento da PNRS.

Para a sua apreciação, os autores selecionaram alguns indicadores do SNIS pela sua relevância na análise da implantação da política, entre os quais o atendimento da coleta domiciliar e volume coletado, a destinação de resíduos e unidades de processamento, a geração de empregos, os custos de coleta, formas de pagamento, a coleta seletiva e recuperação de recicláveis.

Vale ressaltar, que os autores enfatizaram que as pesquisas do setor de resíduos trouxeram informações relevantes para o acompanhamento da implantação da PNRS, porém necessitam de uma análise cuidadosa em razão de 
se basearem em dados primários não validados com documentos ou visitas técnicas.

Os autores concluíram que há muitos desafios para implantação da Política Nacional de Resíduos Sólidos num país continental como o Brasil, particularmente em relação aos Planos de Gestão Integrada de Resíduos Sólidos, ao Sistema Nacional de Informações sobre Resíduos, a Coleta Seletiva, a Logística Reversa e os Incentivos Fiscais, Financeiros e Creditícios, que embora sejam instrumentos acertadamente previstos na lei, ainda não estão adequadamente implantados.

Araújo e Vieira no artigo “A Economia Circular pode ser Solidária” (2017) apresentaram e discutiram conceitos, bases legais e estratégias para que a Economia Circular se disseminasse no Brasil de forma solidária, particularmente no que se refere às iniciativas que fomentam a correta segregação de resíduos sólidos e a reciclagem com inclusão de catadores de materiais recicláveis.

Eles iniciaram o artigo contextualizando que as iniciativas de Economia Circular (EC) se disseminaram a partir da década de 1990, quando se iniciaram as análises dos fluxos de recursos naturais (matéria e energia), rompendo com o modelo linear de produção e consumo e impondo um padrão de produção e consumo com menos impacto ambiental e mais sustentável, tanto na dimensão ambiental quanto social.

Segundo esses autores, no Brasil há uma estrutura legal para a gestão de resíduos sólidos, todavia para que a implantação da Economia Circular se realize de forma solidária será necessário além das leis, à participação da sociedade civil, o estímulo para que os diferentes sujeitos se sintam atraídos ao tema, à introdução de instrumentos tanto regulatórios quanto econômicos, o apoio para cooperativas de catadores e catadoras de materiais recicláveis, com a capacitação técnica em gestão dos (as) catadores (as) e recicladores (as), a sensibilização da sociedade como um todo e o efetivo monitoramento dos programas com indicadores mais detalhados para a Economia Circular.

Besen e Jacobi (2017) expuseram os caminhos das políticas públicas de resíduos sólidos no Brasil para viabilizar a remuneração aos catadores e catadoras de materiais recicláveis na prestação de serviço da coleta seletiva aos municípios e da logística reversa ao setor privado. 
Nesse contexto apresentaram a ação pública que levou os catadores e catadoras a integrarem a agenda de resíduos sólidos no país, a Política Nacional de Saneamento e o seu dispositivo que possibilitou a contratação de associações e cooperativas de catadores e catadoras pelos municípios, a PNRS, com ênfase na responsabilidade compartilhada pelo ciclo de vida do produto, enquanto princípio, e no acordo setorial de embalagens, enquanto instrumento e seu processo de Consulta Pública do acordo setorial de embalagens em geral, no ano de 2014, com foco na análise das contribuições dos vários atores envolvidos.

Apoiados em Jardim et al. (2012), os autores argumentaram que muitas iniciativas ocorreram na agenda federal nos âmbitos legal, administrativo e institucional, no sentido de regular a gestão dos resíduos e promover o fortalecimento das organizações de catadores e de catadoras de materiais recicláveis, com vistas à prestação de serviço da coleta seletiva aos municípios e da logística reversa ao setor privado. Entretanto, as organizações de catadores e catadoras encontravam muitas barreiras no plano legal para se adequar à legislação vigente a fim de serem contratadas para prestação de serviço às prefeituras.

Besen e Jacobi (2017) mostraram que a responsabilidade compartilhada pelo ciclo de vida do produto foi definida na PNRS como o conjunto de atribuições individualizadas e encadeadas dos fabricantes, importadores, distribuidores e comerciantes, dos consumidores e dos titulares dos serviços públicos de limpeza urbana e de manejo dos resíduos sólidos, para minimizar o volume de resíduos sólidos e rejeitos gerados, bem como para reduzir os impactos à saúde humana e à qualidade ambiental decorrentes do ciclo de vida dos produtos.

No entanto, destacaram que no Brasil esse importante instrumento da PNRS apresenta uma grande lacuna e um sério risco, tendo em vista responsabilizar, de forma compartilhada, vários sujeitos sem definir quem vai arcar com os custos da logística reversa das embalagens, apesar de estarem previstos no Acordo Setorial celebrado em 2015 duas fases de execução que, de certa forma, compromete as associações integrantes do referido Acordo em relação aos custos do processo de instalação da logística reversa. 


\subsection{Um pouco de história da Política Nacional de Resíduos Sólidos}

A Lei $n^{\circ} 12.305$ de 02 de agosto de 2010, que instituiu a Política Nacional de Resíduos Sólidos, dispondo sobre seus princípios, objetivos e instrumentos, bem como sobre as diretrizes relativas à gestão integrada e ao gerenciamento de resíduos sólidos, incluindo os perigosos, às responsabilidades dos geradores e do poder público e aos instrumentos econômicos aplicáveis, teve como origem segundo Araújo (2013), o Projeto de Lei (PL) apresentado ao Senado Federal sob o $\mathrm{n}^{\mathrm{o}}$ 354/1989, de autoria do ex-senador Francisco Rollemberg (PFL/SE), que dispunha sobre o acondicionamento, a coleta, o tratamento, o transporte e a destinação final dos resíduos de serviços de saúde.

O Projeto de Lei (PL) apresentado ao Senado Federal estabelecia o conceito e a classificação de resíduos de serviços de saúde, determinava que esses fossem separados e acondicionados na fonte produtora de acordo com procedimentos adequados a cada categoria e definia tanto as responsabilidades dos estabelecimentos geradores dos resíduos, quanto às obrigações da administração municipal, incluindo a manutenção de serviço regular de coleta, transporte e destinação final adequada dos resíduos de serviços de saúde. Além desses aspectos, definia os estabelecimentos sujeitos à aplicação da lei e as sanções.

Conforme sinalizou Araújo (2013) na Câmara dos Deputados o Projeto de Lei ${ }^{\circ} 354 / 1989$ foi recebido em $1^{\circ}$ de abril de 1991, passando a tramitar como PL $n^{\text {o }}$ 203/1991. Ela ressaltou, que a primeira proposta a trazer a ideia de uma lei abrangente sobre a Política Nacional de Resíduos Sólidos foi apresentada por meio do PL n ${ }^{\circ} 3.333 / 1992$, pelo deputado federal Fábio Feldmann (PSDB/SP), preocupado em criar leis próprias para temas que integravam a Política Nacional de Meio Ambiente, mas que não se encontravam abrigados adequadamente pela Lei ${ }^{\circ} 6.938 / 1981$.

O Projeto de Lei $n^{0}$ 3.333/1992 estabelecia que a organização e o gerenciamento dos sistemas de manipulação, acondicionamento, armazenamento, coleta, transporte, tratamento e disposição final dos resíduos sólidos constituíamse em serviço público de caráter essencial, cabendo ao Poder Público Municipal a coleta, o transporte, o tratamento e a disposição final dos resíduos domiciliares, públicos e de unidades de saúde. 
O PL previa também os objetivos, os fundamentos básicos, os instrumentos da Política Nacional de Resíduos Sólidos, os critérios para o gerenciamento dos resíduos sólidos, fixando os procedimentos para resíduos perigosos e para resíduos de serviços de saúde, bem como as penalidades às quais estariam sujeitos os infratores da lei.

Entretanto, o PL não contemplou, como destacou Araújo (2013), a responsabilidade pós-consumo, na qual os fabricantes de produtos e embalagens deveriam ser responsáveis pelo ciclo integral daquilo que colocassem no mercado, recolhendo os produtos e embalagens após o uso pelo consumidor, dando para estes uma destinação ambientalmente correta.

É de salutar importância destacar, que a inclusão da responsabilidade pósconsumo no Projeto de Lei e, posteriormente, a importação de pneus usados para serem utilizados como matéria-prima ou insumo pela indústria nacional de reforma e remoldagem de pneus e a incineração de resíduos se tornariam os grandes impeditivos à aprovação da lei de resíduos.

De acordo com Araújo (2013), após o PL no 3.333/1992 outros projetos de lei, que dispunham sobre variados aspectos relacionados à gestão dos resíduos foram apensados ao processo na década de 1990, desde projetos de caráter mais específicos a outros com perspectivas mais gerais.

Entre os específicos, o PL 4.344/93 e o PL 4.398/94 do deputado Fabio Feldmann, que tornariam obrigatório o estabelecimento, pelos fabricantes de pilhas e de baterias, de mecanismos de disposição final, reciclagem ou outras formas de reprocessamento após o uso pelos consumidores e o PL 4.178/98 do deputado Paulo Paim (PT/RS), que atribuiria aos fabricantes de produtos que resultassem em "lixo" tecnológico a responsabilidade pela coleta, transporte, tratamento, reciclagem e disposição final desses resíduos merecem ênfase.

Já em âmbito mais a amplo mereceu destaque o PL 4.502/98 do deputado Ivan Valente (PT/SP), que instituiria a Política Nacional de Gerenciamento de Resíduos Sólidos, prevendo seus objetivos, fundamentos básicos e instrumentos, bem como normas gerais para o gerenciamento de resíduos sólidos e normas específicas para reciclagem, embalagens, resíduos comuns, resíduos industriais, resíduos de serviços de saúde, resíduos gerados pela utilização de agrotóxicos, resíduos provenientes de portos, aeroportos, terminais ferroviários e rodoviários, 
resíduos perigosos, resíduos tecnológicos, da construção civil e de outros resíduos especiais, além das penalidades pelo descumprimento da lei.

Paralelamente a construção do arcabouço jurídico para regulamentar a política de resíduos sólidos, já havia ocorrido experiências inovadoras na gestão dos resíduos sólidos, envolvendo o poder público e organizações comunitárias, cooperativas e associações de catadores de materiais recicláveis em São Paulo, em Porto Alegre e em Belo Horizonte.

Entretanto, o debate público sobre a gestão e o gerenciamento de resíduos sólidos e, mais precisamente sobre a inclusão socioprodutiva dos catadores e de catadoras de materiais recicláveis ganhou uma grande dimensão com o episódio sobre a intoxicação de crianças no lixão em Olinda, Pernambuco, ocorrido em 1998, suspeitas de ingestão de carne humana proveniente do "lixo" hospitalar contribuiu para trazer a público um problema "invisível” para a sociedade.

Segundo Abreu (2002), no ano de 1998, o Fundo das Nações Unidas para a Infância - UNICEF realizou uma pesquisa no Brasil e estimou que cerca de 45.000 crianças em todo país trabalhavam na catação nos lixões submetidos aos mais variados riscos. Neste mesmo ano, tomou a iniciativa de inserir a erradicação do trabalho infantil com o "lixo" como uma de suas prioridades de ação.

Essa iniciativa do UNICEF contribuiu para ampliar a discussão pública sobre os problemas relacionados aos resíduos sólidos, para a percepção da complexidade da questão e que a solução dependia da conjunção de ações no âmbito político, econômico, cultural, técnico e legal.

Diante dessa conjuntura, o UNICEF concluiu ser necessário um grande movimento envolvendo as entidades públicas, privadas e a sociedade civil para reverter o quadro de degradação socioambiental envolvendo a gestão inadequada dos resíduos sólidos urbanos no País.

Para Abreu (2002), a proposta de união de esforços para o enfrentamento do problema encontrou apoio nas instituições que atuavam no setor, entre as quais o Ministério do Meio Ambiente, a Fundação Nacional de Saúde - FUNASA, a Secretaria Especial de Desenvolvimento Urbano da Presidência da República SEDU, a Caixa Econômica Federal, o Ministério Público, a ONG Missão Criança, a organização dos catadores e as administrações municipais, com destaque para as prefeituras de Porto Alegre e de Belo Horizonte. 
Como desdobramento desse processo, em junho de 1998, um grupo constituído por 19 instituições criou em Brasília, na sede do UNICEF, o Fórum Nacional Lixo \& Cidadania, com as finalidades de erradicar o trabalho de crianças e adolescentes no "lixo", levando-as à escola, de inserir os catadores e as catadoras de materiais recicláveis nos programas de coleta seletiva, reutilização e reciclagem de resíduos e erradicar os lixões, remediando as áreas degradadas e implantando aterros sanitários.

Após um ano de trabalho foi lançada a campanha "Criança no Lixo, Nunca Mais", na qual os prefeitos que assinaram o Termo de Intenção em participar do programa receberam os manuais informativos para atuar na resolução dos problemas, entre eles: o "Manual do Promotor", produzido pelo Ministério Público Federal, o "Manual do Catador", produzido CEMPRE, o "Manual para o Prefeito" - "Criança, Catador \& Cidadão", elaborado pelo UNICEF, "Manual de Financiamento", produzido pelo Ministério do Meio Ambiente, o "Manual da Coleta Seletiva", redigido pelo Instituto Pólis e o "Manual da Bolsa Escola Cidadã” elaborado pela ONG Missão Criança.

Em 1999 foi realizado o I Congresso Nacional dos Catadores de Papel, ocorrido em Belo Horizonte, no qual se discutiu a necessidade da criação de um movimento nacional de catadores.

O IPEA (2013) destacou que, apesar da morosidade do Congresso para aprovar o Projeto de Lei (PL) nº 203/1991, para instituir a política pública em prol da gestão de resíduos, os catadores e as catadoras de materiais recicláveis impulsionavam a sua luta por seus direitos em diversas regiões do Brasil, articulando a organização do Movimento Nacional de Catadores de materiais Recicláveis, que se iniciou no I $^{\mathrm{o}}$ Encontro Nacional de Catadores de Papel, e se consolidou em junho de 2001 no I $^{\circ}$ Congresso Nacional dos Catadores e das Catadoras de Materiais Recicláveis, em Brasília, evento que reuniu mais de 1.700 catadores e catadoras.

Nesse congresso, o Movimento Nacional dos Catadores de Materiais Recicláveis - MNCR, instituição pilar para o fortalecimento da identidade coletiva do segmento, lançou a Carta de Brasília, um documento que expressou as necessidades do povo que sobrevive da coleta de materiais recicláveis.

A Carta de Brasília propôs ao Poder Executivo que garantisse recursos da assistência social para o fomento e subsídios dos empreendimentos de Catadores 
(as) de Materiais Recicláveis, a inclusão dos catadores e das catadoras de materiais recicláveis no Plano Nacional de Qualificação Profissional, priorizando sua preparação técnica nas áreas de gestão de empreendimentos sociais, educação ambiental, coleta seletiva e recursos tecnológicos de destinação final e a adoção de políticas de subsídios que permitam aos catadores e catadoras avançarem no processo de reciclagem de resíduos sólidos, possibilitando o aperfeiçoamento tecnológico dos empreendimentos com a compra de máquinas e equipamentos, como balança e prensas.

Além desses pontos, propôs a definição e implantação, em nível nacional, de uma política de coleta seletiva que priorizasse o modelo de gestão integrada dos resíduos sólidos urbanos, colocando os mesmos sob a gestão dos catadores e das catadoras e a erradicação dos lixões em todo o país, assegurando recursos públicos para a transferência das famílias que viviam neles e financiamento para que pudessem ser implantados projetos de geração de renda a partir da coleta seletiva.

Apesar da ampliação da organização dos movimentos sociais lutando para a consolidação da política nacional de resíduos, Araújo (2013) enfatizou que no Congresso Nacional não houve movimentação política relevante sobre o tema até 2001, quando se estabeleceu a Comissão Especial destinada a proferir parecer ao Projeto de Lei $\mathrm{n}^{\circ}$ 203, de 1991, tendo como relator o deputado Emerson Kapaz PPS/SP, que exerceu um importante papel no sentido de reunir em um único processo legislativo todas as propostas ligadas à gestão dos resíduos sólidos.

Em 2002, a atividade laboral de catador de materiais recicláveis passou a ser inserida pelo Ministério do Trabalho e Emprego - MTE, por meio do Decreto 397, publicado no Diário Oficial da União em 10 de outubro de 2002, na Classificada Brasileira de Ocupação - CBO, sob o código 5192-05.

Esse reconhecimento oficial da categoria, por meio da formalização desta atividade profissional como ocupação, além de possibilitar uma melhor identificação da categoria na Pesquisa Nacional por Amostragem de Domicílios PNAD correspondeu à conquista dos direitos da cidadania dos catadores e das catadoras, conforme demonstrou Bastos (2008).

Segundo o relatório da Comissão Especial da Política Nacional de Resíduos (2006), dada à diversidade da matéria, a Comissão Especial não logrou consenso na aprovação do Relatório no decurso da legislatura 1999/2003. Dessa forma, em 
conformidade ao Regimento Interno da Câmara dos Deputados, uma nova Comissão foi instalada para dar prosseguimento ao processo legislativo.

Para Araújo (2013), a não aprovação deveu-se ao elevado grau de conflito de interesses, em particular das entidades representativas do empresariado que se colocaram praticamente em bloco contra a lei, a falta de habilidade na articulação política do relator Emerson Kapaz e por tramitar em um período eleitoral.

Contudo, destacou que apesar da não aprovação o relatório introduziu discussões importantes, entre as quais a separação dos debates sobre a Lei dos Resíduos Sólidos e a Lei do Saneamento Básico, a previsão do Cadastro Nacional de Operadores de Resíduos Perigosos, a diferenciação entre gestão de resíduos, conceito abrangente, e seu gerenciamento, conceito mais operacional, a verificação da necessidade de dar mais atenção aos catadores e as catadoras de materiais recicláveis e a percepção da dificuldade de a lei disciplinar detalhadamente sobre cada categoria de resíduos sólidos.

No ano de 2003, Luiz Inácio Lula da Silva tornou-se presidente do Brasil e convidou Marina Silva, uma histórica militante das causas ambientais, para ser Ministra do Meio Ambiente, e importantes ativistas dos movimentos ambientalistas para ocupar vários cargos no Ministério, sinalizando em direção ao comprometimento com as causas ecológicas e de que a variável ambiental seria incorporada como prioritária ao planejamento das ações do governo.

Se por um lado, alguns autores argumentaram que em nível macro a política ambiental dos governos do presidente Lula no período 2003-2010 foi colocada em segundo plano, em função da política desenvolvimentista, como afirmou Bergamini (2010), ao mostrar por meio da distribuição orçamentária da União, que o Ministério do Meio Ambiente (MMA) recebeu um valor R \$ 9,8 bilhões, valor esse irrisório se comparado a outros Ministérios.

Por outro lado, muitos autores afirmaram que houve avanços na política pública sobre os resíduos sólidos, sobretudo com a promulgação da Lei $\mathrm{n}^{\circ}$ 12.305/10, instituindo a Política Nacional de Resíduos Sólidos.

Para Besen (2011), com a instalação do Governo Lula e no âmbito do projeto Fome Zero, o MNCR iniciou uma interlocução direta com a Presidente da República tornando a questão uma prioridade nacional, sendo estabelecidas a partir de então, políticas públicas afirmativas de inclusão social dos catadores e 
das catadoras e de financiamento visando o fortalecimento e a sustentabilidade das organizações deste segmento.

Ainda segundo Besen (2011), foi criado, no ano de 2003, o Comitê Interministerial de Inclusão Social de Catadores de Lixo (CIISC), com a finalidade de coordenar as ações do governo federal no âmbito dos resíduos, em particular na inclusão social dos catadores e das catadoras e no apoio à gestão integrada dos resíduos nos municípios, fomentando a expansão da coleta seletiva, da reutilização e da reciclagem por meio da atuação desses catadores de materiais reutilizáveis.

De acordo com o IPEA (2013), nesse mesmo ano foi realizada a primeira Conferência do Meio Ambiente e instituído o Grupo de Trabalho Interministerial de Saneamento Ambiental, a fim de promover a integração das ações de saneamento ambiental no âmbito do governo federal, reestruturando o setor de saneamento e resultando na criação do Programa Resíduos Sólidos Urbanos.

Também foi realizado em Caxias do Sul o I Congresso Latino-Americano de Catadores, no qual foi proposta a intensificação do intercâmbio entre as iniciativas e organizações de catadores e catadoras de materiais recicláveis de toda a América Latina, visando à construção de redes de cooperativas, associações e empresas comunitárias e a futura criação de um movimento latinoamericano desse setor.

O reconhecimento do trabalho dos catadores e das catadoras na limpeza pública, a regulamentação da profissão, a erradicação dos lixões, a implantação de aterros sanitários e a garantia de investimentos para a implantação de infraestrutura para o segmento, com criação de linhas de crédito específicas para grupos organizados, além de políticas públicas de fomento e incentivo para a capacitação e formação de catadores foram outros pontos centrais.

O Congresso Latinoamericano de Catadores ainda propôs o acesso dos catadores e das catadoras aos benefícios da Previdência Social, a luta contra a privatização do setor, a garantia de programas de alfabetização e de formação para os catadores e as catadoras e que os programas de coleta seletiva fossem implantados prioritariamente em parceria com as organizações deste segmento.

Segundo o site http://www.mma.gov.br/cidades-sustentaveis/residuossolidos/politica-nacional-de-residuos-solidos/linha-do-tempo.html, no ano de 2004, o Ministério do Meio Ambiente promoveu grupos de discussões 
interministeriais e de secretarias ministeriais para elaboração de proposta para a regulamentação dos resíduos sólidos.

No mesmo ano, o Conselho Nacional de Meio Ambiente - CONAMA realizou o seminário "Contribuições à Política Nacional de Resíduos Sólidos" com a finalidade de formular nova proposta de projeto de lei, pois a Proposição CONAMA 259 estava defasada.

Em 2005, foi criado um grupo interno na Secretaria de Qualidade Ambiental nos Assentamentos Humanos do Ministério do Meio Ambiente - MMA para consolidar as contribuições do Seminário CONAMA e dos diversos sujeitos envolvidos na gestão de resíduos sólidos aos anteprojetos de lei existentes no Congresso Nacional.

Também foi encaminhado o anteprojeto de lei de "Política Nacional de Resíduos Sólidos”, debatido com Ministérios das Cidades, da Saúde, por meio da FUNASA, do Desenvolvimento, Indústria e Comércio Exterior, do Planejamento, Orçamento e Gestão, do Desenvolvimento Social e Combate à Fome e da Fazenda.

Ainda nesse ano, ocorreu o $2^{\circ}$ Congresso Latinoamericano de Catadores (as), dando continuidade a articulação latina para abertura das novas frentes de luta na busca de direitos para os catadores (as) de outros países da América Latina.

No Congresso foi proposto, dentre outras coisas, reforçar e multiplicar as associações e as cooperativas como bases orgânicas do Movimento, aumentando a participação com a prática da democracia direta, avançar na soma de comitês regionais, lutando para controlar a cadeia produtiva da reciclagem por meio de redes ou centrais de produção e comercialização, ampliar o processo permanente de formação e capacitação, garantindo maior autonomia nas lutas para conquistar direitos, à Previdência Social pública e à remuneração pelo trabalho socioambiental realizado pelos catadores e catadoras e as suas organizações e denunciar os que exploravam e tratavam com preconceitos e violência os catadores e catadoras).

Ainda em 2005, foi realizada II Conferência Nacional de Meio Ambiente, para consolidar a participação da sociedade na formulação de políticas ambientais, na qual um dos temas centrais fora os resíduos sólidos. 
Araújo (2013) destacou que em agosto de 2005, depois de um hiato de dois anos foi formada uma nova Comissão Especial para dar continuidade ao processo legislativo e para proferir parecer ao Projeto de Lei 203/91 e os então já 106 projetos a ele apensados, tendo como relator o deputado Ivo José (PT/MG), que venceu o deputado Luciano Zica (PT/SP) numa disputa interna no partido para assumir a relatoria.

Segundo Araújo (2013), formada a Comissão confirmou-se que o Poder Executivo pretendia intervir com mais intensidade no processo. Primeiramente, com a indicação do relator do PL. Em seguida, pela síntese do texto que estava debatendo internamente na Secretaria de Qualidade Ambiental nos Assentamentos Humanos e que teve o apoio do MNCR, do Fórum Nacional Lixo e Cidadania e de outras organizações.

A Comissão Especial da Política Nacional de Resíduos tratou sobre a coleta seletiva, a compostagem de resíduos orgânicos, a reciclagem de resíduos, a destinação final, os resíduos de embalagens e reuso de embalagens, rotulagem e classificação, a obrigação de compra governamental de papel reciclado, a logística reversa de pet, de vidros e de plásticos, o apoio creditício e de fundos para gestão de resíduos sólidos, o incentivo fiscal, a importação e destinação final de pneus, a importação de resíduo nuclear e de resíduo industrial, as pilhas e as baterias, as lâmpadas de vapor de mercúrio, os resíduos de mineração e da construção civil, a moratória de instalação de incineradores, o resíduo hospitalar, de clínicas e de ambulatórios, o resíduo nuclear, o resíduo perigoso e o resíduo tecnológico.

Ivo José no relatório final da Comissão Especial da Política Nacional de Resíduos (2006) evidenciou a metodologia utilizada para a produção do projeto de lei, que se constituiu de um plano de trabalho, um cronograma e um modus operandi, com a previsão de várias audiências públicas para ouvir entidades representativas, objetivando uma interação entre as três esferas de governo, a sociedade civil e o setor produtivo.

O resultado da Comissão foi encaminhado com algumas inovações, entre as quais os planos de gestão integrada de resíduos, a substituição do termo responsabilidade pós-consumo pela logística reversa, e propostas com diretrizes mais gerais, sem detalhamento de regras, fazendo com que a mesma começasse a ser aceita pelo empresariado. 
Araújo (2013) destacou, entretanto, que apesar do avanço no sentido do consenso pela maior abertura dos industriais e empresários a uma lei nacional sobre resíduos e pela maior presença do Executivo, após o parecer do relator os conflitos se acirraram, sobretudo, pela inclusão ao seu primeiro substitutivo de um conjunto de dispositivos que facilitavam a importação de pneus usados, o que contrariava a linha de atuação do Poder Executivo e enfraquecia a articulação intrassetorial, que marcava as propostas para a futura lei.

Tal posicionamento, segundo Araújo (2013), gerou a oposição de quase todos os sujeitos que participavam do debate, entre eles, o MMA, os ambientalistas, a Associação Nacional da Indústria de Pneumáticos - ANIP, a Confederação Nacional da Indústria - CNI e a Federal das Indústrias do Estado de São Paulo - FIESP e gerou o rompimento do relator com o PT e, consequentemente, sua saída da relatoria.

A autora afirmou que a substituição do deputado Ivo José pelo deputado Feu Rosa (PP/ES) para a relatoria não impediu a aprovação por ampla maioria do parecer, mas como o deputado Feu Rosa era autor de projetos apensados, foi solicitado que a votação da Comissão Especial fosse invalidada e novo relator fosse escolhido. A solicitação foi deferida e o deputado César Silvestri (PPS/PR) também manteve o parecer, que foi aprovado em 04 de julho de 2006.

No ano 2006 foi instituído o Decreto 5.940, estabelecendo a coleta seletiva solidária, determinando a separação dos resíduos recicláveis descartados pelos órgãos e entidades da administração pública federal direta e indireta, na fonte geradora, e a sua destinação às associações e cooperativas dos catadores de materiais recicláveis.

Neste mesmo ano, segundo o estudo do IPEA (2013), o MNCR realizou a grande marcha até Brasília levando suas demandas para o Governo Federal, e propondo a criação de postos de trabalho em cooperativas e associações, bases orgânicas do movimento. Esse evento, que se tornou um marco histórico da luta do segmento no Brasil, reuniu cerca 1.200 catadores e catadoras que marcharam na Esplanada dos Ministérios e levaram às autoridades as suas reivindicações.

Em 2007, foi sancionada a Lei 11.445/07, instituindo a Política Nacional de Saneamento Básico, estabelecendo as diretrizes nacionais para o saneamento básico e para a política federal de saneamento básico. Essa lei definiu que os serviços públicos de saneamento básico deveriam ser prestados com base no 
princípio da universalização do acesso aos serviços de abastecimento de água, esgotamento sanitário, limpeza urbana e manejo dos resíduos sólidos, realizados de formas adequadas à saúde pública e à proteção do meio ambiente.

No que tange à organização dos catadores e das catadoras, a lei foi crucial no sentido de estabelecer a dispensa de licitação para contratação de associações ou cooperativas para a prestação de serviço de coleta seletiva pelo poder público municipal.

Araújo (2013) enfatizou que, apesar do histórico de controle da agenda do Legislativo pelo Executivo que marca o presidencialismo de coalizão brasileiro, a única proposta encaminhada pelo Presidente da República nesse processo veio apenas em 2007, dezesseis anos após o início do trâmite no Congresso Nacional. Nesse contexto, residia o desejo de ter mais influência no conteúdo da futura lei, tendo em vista que o PT havia perdido controle sobre o conteúdo na Comissão Especial, mesmo com o relator do partido.

Segundo o site http://www.mma.gov.br/cidades-sustentaveis/residuossolidos/politica-nacional-de-residuos-solidos/linha-do-tempo.html, o projeto de lei da Política Nacional de Resíduos Sólidos, considerou que o estilo de vida da sociedade contemporânea, aliado às estratégias de marketing do setor produtivo, levam a um consumo intensivo, provocando uma série de impactos ambientais à saúde pública e sociais incompatíveis com o modelo de desenvolvimento sustentado que se pretendia implantar no Brasil.

Nesta perspectiva, o PL 1991/2007 apresentava forte inter-relação com outros instrumentos legais na esfera federal, tais como a Lei de Saneamento, a Lei dos Consórcios Públicos, e seu Decreto regulamentador, além de intrinsecamente relacionado com as Políticas Nacionais de Meio Ambiente, de Educação Ambiental, de Recursos Hídricos, de Saúde, Urbana, Industrial, Tecnológica e de Comércio Exterior e as que promovam inclusão social.

No ano de 2008, o Poder Executivo, ciente da dificuldade em obter consenso entre os diversos setores envolvidos no debate do Projeto de Lei sobre resíduos, constituiu um grupo de trabalho coordenado pelo deputado da Frente Ambientalista, Arnaldo Jardim (PPS/SP), que apesar de não integrar a base do PT não sofreu resistência, tendo em vista o seu bom trânsito na Casa e o conhecimento e a experiência na temática dos resíduos sólidos, sendo inclusive o 
coordenador do Grupo de Trabalho - GT, que formulou a lei paulista sobre resíduos sólidos.

Segundo Araújo (2013), o deputado Arnaldo Jardim promoveu audiências públicas e reuniões técnicas, que contaram com a participação de uma gama de instituições, entre elas a Associação Brasileira de Empresa de Tratamento de Resíduos e Efluentes - ABETRE, Associação Brasileira de Indústria de Alimentação - ABIA, Associação Brasileira de Indústria Pet - ABIPET, Associação Brasileira de Resíduos e Limpeza Urbana - ABLP, Associação Brasileira de Empresas de Limpeza Pública e Resíduos Especiais - ABRELPE, Compromisso Empresarial para a Reciclagem - CEMPRE, Centro Gaspar Garcia de Direitos Humanos, Centro de Tecnologia de Embalagem - CETEA, Confederação Nacional das Indústrias - CNI, Fórum Lixo e Cidadania, Movimento Nacional de Catadores de Materiais Recicláveis - MNCR, Rede das Agendas 21, Sindicatos das Empresas de Limpeza Urbana - SELURB e organizações não governamentais ambientalistas como a SOS Mata Atlântica.

Um ponto central inserido pelo relator Arnaldo Jardim foi o conceito da responsabilidade compartilhada pelo ciclo de vida dos produtos, no qual as obrigações não se esgotariam na responsabilidade pós-consumo do setor produtivo, englobando dessa forma os fabricantes, os importadores, os distribuidores, os comerciantes, os consumidores e os titulares dos serviços públicos de limpeza urbana e de manejo dos resíduos sólidos.

Para Araújo (2013), a introdução desse conceito reduziu as divergências e os conflitos e facilitou a aceitação do PL por parte dos industriais e empresariado, em função estabelecer a ideia de que todos têm responsabilidades na minimização do volume de resíduos sólidos e rejeitos gerados, bem como na redução dos impactos causados à saúde humana e à qualidade ambiental decorrentes do ciclo de vida dos produtos.

Cabe destacar, todavia, que o texto redigido pelo relator não foi totalmente aceito pelo Movimento Nacional de Catadores de Materiais Recicláveis devido à ausência de garantias quanto ao pagamento dos serviços prestados pelos catadores e catadoras tanto pelo setor público, como pelo empresarial. Além deste aspecto, no que tange o incentivo à criação e ao desenvolvimento de cooperativas ou outras formas de associação de catadores e catadoras de materiais recicláveis não ficou definido no texto as formas de fomento, ou seja, as fontes de financiamento. 
Araújo (2013) apontou que o trabalho do GT foi concluído, em outubro de

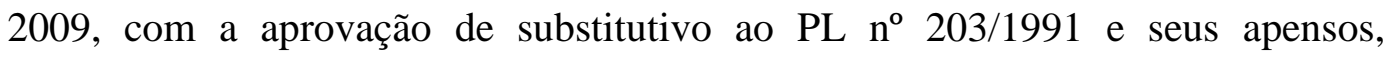
oferecido pelo coordenador do grupo, com a supressão de dispositivos que tratavam da concessão de incentivos econômicos a atividades relacionadas à reciclagem e ao tratamento de resíduos sólidos. Sendo assim, o texto negociado pelo Deputado Arnaldo Jardim é bastante próximo do que viria a ser a versão sancionada da lei.

Apesar das divergências o substitutivo da Câmara dos Deputados ao PL n ${ }^{\circ}$ 203/1991 e apensos foi aprovado em 07 de julho de 2010.

No dia 2 de agosto, o presidente Luiz Inácio Lula da Silva, sancionou a Lei $\mathrm{n}^{\mathrm{o}}$ 12.305/10, que estabeleceu a Política Nacional de Resíduos Sólidos. Este marco regulatório sobre resíduos instituiu entre outros aspectos a responsabilidade compartilhada com a integração dos catadores e das catadoras de materiais recicláveis e reutilizáveis. Além disso, priorizou para obtenção de recursos da União os municípios que implantassem a coleta seletiva com a participação das cooperativas ou outras formas de associação de catadores e catadoras de materiais reutilizáveis e recicláveis.

Ainda em 2010, destacou o IPEA (2013), foram instituídos, em 23 de dezembro, os Decretos $n^{\circ} 7.404$ e $n^{\circ} 7.405$.

O Decreto $n^{\circ} 7.404 / 10$ que regulamentou a Lei no $12.305 / 10$ estabeleceu as normas para execução da política e criou o Comitê Interministerial da Política Nacional de Resíduos Sólidos ${ }^{13}$ e o Comitê Orientador para a Implantação dos Sistemas de Logística Reversa.

Ao Comitê Interministerial da Política Nacional de Resíduos Sólidos, órgão colegiado de caráter deliberativo e consultivo, com a finalidade de apoiar a estruturação e implantação da Política Nacional de Resíduos Sólidos, compete instituir os procedimentos para elaboração, avaliação, implantação do Plano Nacional de Resíduos Sólidos, promover estudos e propor medidas visando à

13 O Comitê Interministerial da Política Nacional de Resíduos Sólidos, composto por representantes, titulares e suplentes, do Ministério do Meio Ambiente, que o coordenará, da Casa Civil da Presidência da República, do Ministério das Cidades, do Ministério do Desenvolvimento Social e Combate à Fome, do Ministério da Saúde, do Ministério de Minas e Energia, do Ministério da Fazenda, do Ministério do Planejamento, Orçamento e Gestão, do Ministério do Desenvolvimento, Indústria e Comércio Exterior, do Ministério da Agricultura, Pecuária e Abastecimento, do Ministério da Ciência e Tecnologia e da Secretaria de Relações Institucionais da Presidência da República. 
desoneração tributária de produtos recicláveis e reutilizáveis, promover estudos visando à criação de condições para a utilização de linhas de financiamento ou creditícias de instituições financeiras federais, formular estratégia para a promoção e difusão de tecnologias limpas para a gestão e o gerenciamento de resíduos sólidos e incentivar a pesquisa e o desenvolvimento nas atividades de reciclagem, reaproveitamento e tratamento dos resíduos sólidos.

Já o Decreto $\mathrm{n}^{\mathrm{o}}$ 7.405/10 instituiu o Programa Pró-Catador, denominado Comitê Interministerial para Inclusão Social e Econômica dos Catadores de Materiais Reutilizáveis e Recicláveis, tendo como finalidades integrar e articular as ações do Governo Federal voltadas ao apoio e ao fomento à organização produtiva dos catadores de materiais reutilizáveis e recicláveis, melhorar as condições de trabalho, à ampliação das oportunidades de inclusão social e econômica e à expansão da coleta seletiva de resíduos sólidos, da reutilização e da reciclagem por meio da atuação desse segmento ${ }^{14}$.

\subsection{As fragilidades, contradições, limites e possibilidades da Política Nacional de Resíduos Sólidos}

Após oito anos da promulgação da Política Nacional de Resíduos Sólidos, o principal instrumento ambiental para gestão integrada e o correto gerenciamento de resíduos sólidos, verificamos avanços socioambientais. Entretanto, como apontou o relatório do Tribunal de Contas da União - TCU (2016) há um conjunto fragilidades no planejamento, na avaliação, na fiscalização, na transparência e no monitoramento das ações governamentais, o que tem ocasionado sérias consequências sociais, ambientais, econômicas e de saúde pública, particularmente para os catadores e as catadoras de materiais recicláveis, o elo mais frágil da cadeia de reciclagem.

O relatório da Controladoria Geral da União - CGU (2016) concluiu que as principais fragilidades da PNRS decorrem da perda de relevância do tema resíduos no planejamento governamental de longo prazo, da baixa execução orçamentária e financeira das ações destinadas à implantação da PNRS, da

\footnotetext{
${ }^{14}$ Este decreto considera catadores e catadoras de materiais reutilizáveis e recicláveis as pessoas físicas de baixa renda que se dedicam às atividades de coleta, triagem, beneficiamento, processamento, transformação e comercialização de materiais reutilizáveis e recicláveis.
} 
descontinuidade do aporte de recursos aos entes federados e aos consórcios públicos para a elaboração de planos de resíduos sólidos, da baixa efetividade nas capacitações realizadas pelo Ministério do Meio Ambiente - MMA, da atuação insuficiente do Comitê Interministerial da PNRS no apoio e na estruturação da política e dos problemas relacionados à versão atual do Sistema Nacional de Resíduos Sólidos - SINIR, que não atende ao previsto no Decreto n 7.404/2010.

Como consequência, temos o seguinte quadro:

A União não publicou o Plano Nacional de Resíduos Sólidos, muitos Estados não elaboraram o seu Plano Estadual de Resíduos e a maioria dos municípios brasileiros não concluiu ou publicou seus Planos Municipais de Resíduos Sólidos. Tais deficiências prejudicam o planejamento, a implantação, a avaliação, o monitoramento e a fiscalização da PNRS.

O Art. $8^{\circ}$ da Política Nacional de Resíduos Sólidos estabeleceu os planos de resíduos sólidos como um dos seus principais instrumentos para aplicação da lei.

No art. $14^{\circ}$ são definidos os tipos de planos, entre eles o Plano Nacional de Resíduos Sólidos, os Planos Estaduais de Resíduos Sólidos, os Planos Microrregionais de Resíduos Sólidos e os Planos de Resíduos Sólidos de Regiões Metropolitanas ou Aglomerações Urbanas, os Planos Intermunicipais de Resíduos Sólidos, os planos Municipais de Gestão Integrada de Resíduos Sólidos e os Planos de Gerenciamento de Resíduos Sólidos.

O Art. $15^{\circ}$ da PNRS determinou que a União elaborasse, sob a coordenação do Ministério do Meio Ambiente, o Plano Nacional de Resíduos Sólidos, com vigência por prazo indeterminado e horizonte de 20 (vinte) anos, a ser atualizado a cada 04 (quatro) anos.

O referido Plano deveria conter minimamente o diagnóstico da situação atual dos resíduos sólidos, a proposição de cenários, incluindo tendências internacionais e macroeconômicas, as metas de redução, reutilização e reciclagem com vistas a reduzir a quantidade de resíduos e rejeitos encaminhados para disposição final ambientalmente adequada, as metas para a eliminação e a recuperação dos lixões, associadas à inclusão social e à emancipação econômica dos catadores e das catadoras de materiais reutilizáveis e recicláveis e os programas, projetos e ações para o atendimento das metas previstas.

Além desses pontos, deveria apontar ainda para as normas e condicionantes técnicas para o acesso a recursos da União, as medidas para incentivar e viabilizar 
a gestão regionalizada dos resíduos sólidos, as diretrizes para o planejamento e demais atividades de gestão de resíduos sólidos das regiões integradas de desenvolvimento instituídas por lei complementar, bem como as normas e diretrizes para a disposição final de rejeitos e, quando coubesse, de resíduos, e os meios a serem utilizados para o controle e a fiscalização, no âmbito nacional, de sua implantação e operacionalização, assegurando o controle social.

No Art. $47^{\circ}$ do Decreto 7.404/2010, que regulamentou a PNRS, determinouse um roteiro para a elaboração do Plano Nacional de Resíduos Sólidos.

De acordo com o roteiro, primeiramente deveria ser feita a formulação e a divulgação da proposta preliminar em até cento e oitenta dias, contados a partir da publicação do Decreto, acompanhada dos estudos que o fundamentariam. Em seguida, o plano deveria ser submetido à consulta pública pelo prazo mínimo de sessenta dias, contados da data da sua divulgação.

Após esses primeiros passos, a proposta do Plano deveria incorporar as contribuições advindas da consulta e das audiências públicas para apreciação dos Conselhos Nacionais de Meio Ambiente, das Cidades, de Recursos Hídricos, de Saúde e de Política Agrícola.

Por fim, o Ministro do Meio Ambiente, que coordenou a elaboração do Plano, o encaminharia ao Presidente da República para que o Decreto fosse publicado.

A versão preliminar do Plano Nacional de Resíduos Sólidos, elaborada sob a coordenação do Comitê Interministerial da Política Nacional de Resíduos Sólidos - CI, composto por 12 ministérios, contendo o diagnóstico dos resíduos sólidos no Brasil, o cenário proposto 2031, além das diretrizes, estratégias e metas da gestão ambientalmente adequada dos resíduos sólidos foi concluída em agosto de 2012.

Conforme constava no site (http://www.sinir.gov.br/web/guest/planonacional-de-residuos-solidos), a versão preliminar do Plano Nacional de Resíduos foi discutida com os setores públicos e privados e com a sociedade em geral. Foram realizadas 05 (cinco) Audiências Públicas Regionais em Curitiba, Recife, Campo Grande, São Paulo e Belém, 02 (duas) audiências não oficiais no Rio de Janeiro e em Belo Horizonte e 01 (uma) audiência pública nacional, em Brasília. 
Conforme sinalizou o site, todas as Audiências Públicas foram realizadas em parceria com os Estados, sendo recepcionadas aproximadamente 1.000 propostas.

Destacou ainda que a Consulta Pública fosse disponibilizada por 60 dias na internet e que qualquer cidadão poderia fazer contribuições ou propor alterações em todo o conteúdo do Plano. Nessas consultas foram apresentadas 450 (quatrocentos e cinquenta) propostas, das quais 190 (cento e noventa) foram incorporadas e 318 (trezentos e dezoito) descartadas por diferentes motivos, sendo que todas foram devidamente justificadas.

O documento final ficou com 29 diretrizes, 170 estratégias e 28 metas após os ajustes, as adequações e a apreciação dos Conselhos Nacionais de Meio Ambiente, das Cidades e de Saúde.

Como podemos verificar, o procedimento para elaboração do Plano Nacional de Resíduos exigiu a mobilização do Governo Federal e uma relativa participação da sociedade. Todavia, como apontou a Confederação Nacional dos Municípios - CNM (2015), um dos pré-requisitos para aprovação do Plano Nacional não foi cumprido, uma vez que o Conselho Nacional de Política Agrícola - CNPA jamais se reuniu para deliberar a respeito do Plano, o que impediu que o Decreto Presidencial fosse publicado.

Segundo o relatório TCU (2016), o Ministério do Meio Ambiente (MMA), em sua função de coordenador da elaboração do Plano, encaminhou por duas vezes solicitação de apreciação ao Ministério da Agricultura, Pecuária e Abastecimento - MAPA, órgão ao qual o CNPA está vinculado. No entanto, o Ministério do Meio Ambiente foi informado que o referido Conselho se encontrava desativado, não tendo realizado nenhuma reunião desde 2011.

Assim, por meio do Ofício de Requisição 02/2016, o MAPA foi questionado a respeito das razões para a minuta do Plano Nacional de Resíduos Sólidos não ter sido apreciada pelo Conselho Nacional de Política Agrícola. Por sua vez, o MAPA encaminhou o Oficio $n^{\circ} 328 / 2016 /$ SE-MAPA em que se limitou a informar que tomou algumas providências, mas que o assunto estava pendente de solução desde 2012.

Ainda segundo o relatório, a resposta do MAPA informou que a última reunião do CNPA fora realizada em 2008 e que não havia previsão de nova reunião em curto prazo. Sendo assim, foram realizadas discussões técnicas na 
pasta nas quais se acordou que a possibilidade de viabilizar o parecer do Conselho em curto tempo seria sua aprovação 'ad referendum'.

Para tanto, seria necessária a publicação de Decreto presidencial concedendo essa faculdade ao Presidente do CNPA para decidir sobre matérias urgentes de outras Pastas.

Em sequência, apontou o relatório, foi encaminhada proposta do Decreto à Presidência da República através das Exposições de Motivos EM n. 00031/2012MAPA (fls. 107 a 109, devolvida para novo referendo do então Ministro da Agricultura, Pecuária e Abastecimento), e EM n. 0034/2014-MAPA, que foi devolvida ao MAPA, em setembro de 2014, solicitando a devolução, tendo em vista acordo do Secretário-Executivo Adjunto da Casa Civil com os Ministros do MAPA e do MMA no sentido de resolver a questão por meio de alteração em outro Decreto, a cargo do MMA, em coautoria com o MAPA.

Após toda a tramitação, não foi verificada nenhuma providência no sentido de realizar a publicação de alteração em outro Decreto. Desse modo, o assunto continuava pendente desde 2012, mas mesmo que tivesse ocorrido a solução passados seis anos, o Plano estaria desatualizado, necessitando, portanto, de reformulação para dar conta das mudanças ocorridas no país.

Como resultado desse processo, o CNM (2015) ressaltou que por não ter se tornado um Decreto, o Plano Nacional de Resíduos Sólidos se concretizou apenas como uma ficção na qual podem ser considerados apenas os estudos e os diagnósticos sobre resíduos sólidos no Brasil.

A auditoria da Controladoria Geral da União - CGU (2017) afirmou que, embora não tenha sido publicado, o Ministério do Meio Ambiente considerava que o Plano existia e que passava por uma revisão devido à previsão de atualização a cada quatro anos.

Assim, foi realizado o Termo de Referência - TR que tratava da contratação de pessoa jurídica para a elaboração de documentos técnicos com vistas a subsidiar o processo de revisão do Plano, com a previsão da sua conclusão para meados de 2019.

O relatório da CGU (2017) destacou que a execução do trabalho deveria pautar-se em dados secundários, a partir prioritariamente de bases de dados oficiais do governo e outras fontes reconhecidas e confiáveis, conforme detalhado para cada produto do TR, e que, além disso, estava prevista a possibilidade da 
contratada realizar estudos e análises específicas com objetivo de complementar dados ou sanar inconsistência.

Desse modo, assim como na versão preliminar do Plano Nacional de Resíduos Sólidos, a maior dificuldade para se fazer um diagnóstico adequado sobre resíduos sólidos seria a necessidade de geração de dados primários com maior abrangência e periodicidade.

De acordo com o site do Ministério do Meio Ambiente (http://www.mma.gov.br/component/k2/item/10611-planos.estaduais), referente ao ano de 2015, doze Estados concluíram o seu Plano de Resíduos Sólidos, a saber: Acre, Alagoas, Amazonas, Ceará, Maranhão, Pará, Pernambuco, Piauí, Rio de Janeiro, Rio Grande do Sul, Sergipe, São Paulo, correspondendo a 45\% dos Estados.

Já o site da Confederação Nacional dos Municípios (http://www.lixoes.cnm.org.br) afirmou que apenas os Estados do Maranhão, Pernambuco, Rio de Janeiro, Santa Catarina, São Paulo e Sergipe finalizaram o Plano Estadual de Resíduos Sólidos.

Afirmou ainda que 17 (dezessete) Estados estavam elaborando, 03 (três) Estados não iniciaram a elaboração e que 01 (um) sequer informou sua situação sobre o Plano Estadual.

Já no que tange aos municípios brasileiros o IBGE (2013), apontou que cerca de 1/3 (33,5\%), representando 1.868 municípios possuíam Plano de Gestão Integrada de Resíduos Sólidos, nos termos estabelecidos pela Política Nacional de Resíduos Sólidos, conforme demonstrou a figura abaixo. 
Figura 1: Percentual de municípios com Plano de Gestão Integrada de Resíduos, 2013.

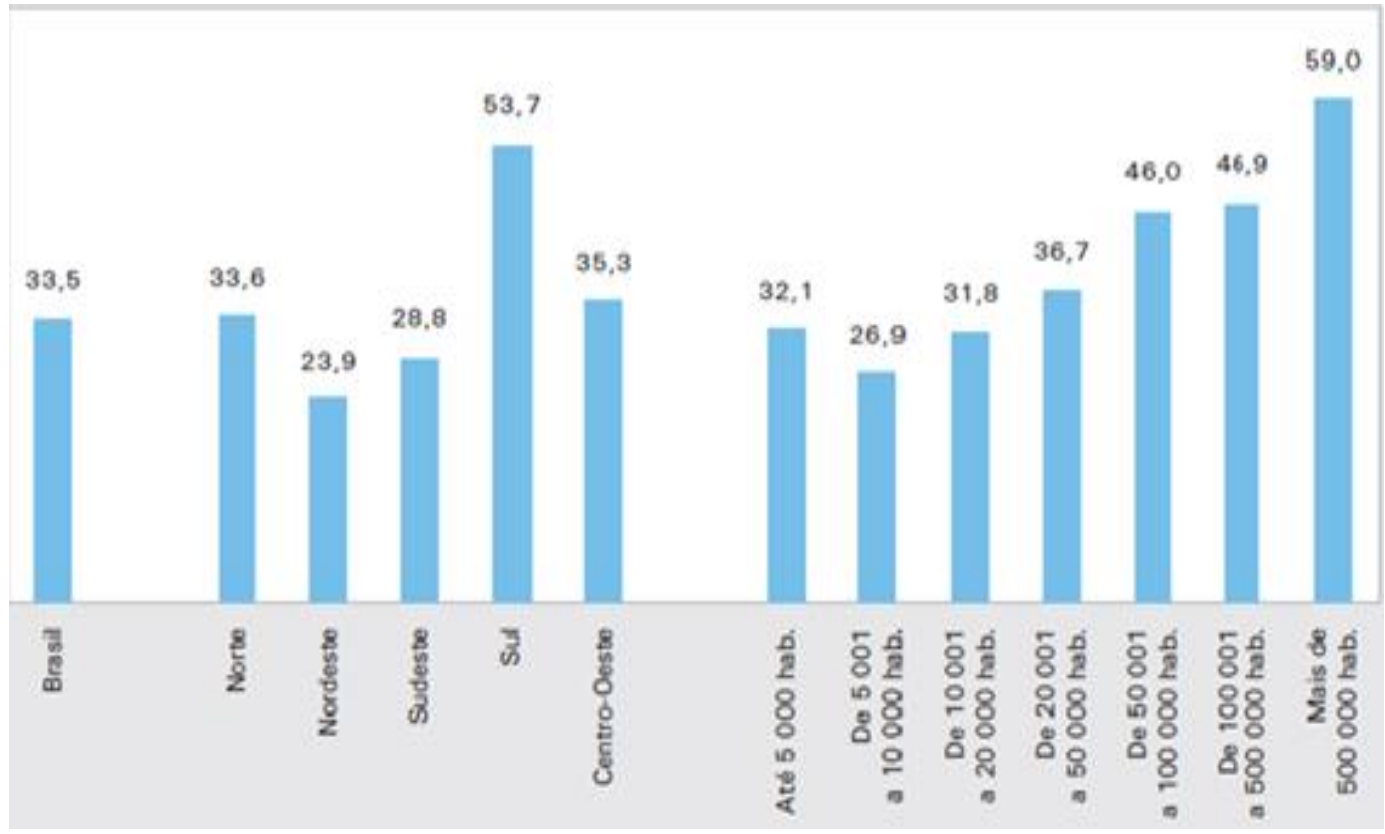

Fonte: IBGE, Pesquisas de Informações Básicas Municípios, 2013.

Ainda de acordo com o IBGE (2013) $)^{15}$, a Região Sul, com 53,7\% era a que possuía municípios com mais Planos de Gestão Integrada, seguida das Regiões Norte $(33,6 \%)$ e Centro-Oeste $(35,3 \%)$, ficando o Sudeste $(28,8 \%)$ e o Nordeste $(23,9 \%)$ com os menores índices.

Em termos de Estado, os maiores percentuais de municípios com Planos de Gestão Integrada foram encontrados no Amazonas (80,6\%) e no Paraná $(63,4 \%)$, já os menores índices foram dos Estados do Acre (4,5\%, com apenas um município em 22) e do Piauí (6,7\%, com apenas 15 municípios em 224).

Outro aspecto relevante destacado pelo IBGE (2013) foi que o percentual de municípios com Plano de Gestão Integrada de Resíduos Sólidos aumentava à medida que se avança para as maiores classes de tamanho da população. A partir da faixa de 5.001 a 10.000 habitantes, foram registrados o percentual de $26,9 \%$, nos municípios com mais de 500.000 habitantes verificou-se $59,0 \%$, já os

15 O IBGE realizou a Pesquisa de Informações Básicas Municipais - Munic 2011, na qual investigou as 5.565 municipalidades existentes no País, obtendo dados relativos à gestão e à estrutura dos municípios, a partir da coleta de informações sobre sete temas, contemplando questões relacionadas ao perfil dos gestores municipais, recursos humanos, articulações interinstitucionais, educação, saúde, habitação, direitos humanos e saneamento básico, este último referencial à pesquisa. Em 2013, o IBGE produziu ainda a Pesquisa de Informações Básicas Municipais - Munic, na qual investigou as 5.570 municipalidades, ou seja, 05 municípios a mais do que no Munic 2011. 
municípios com até 5.000 habitantes, 32,1\% possuíam Plano de Gestão Integrada de Resíduos Sólidos.

Conforme destacou o site (http://www.mma.gov.br/mma-emnumeros/residuos-solidos) do Ministério do Meio Ambiente, em 2015, no que se refere aos Planos Municipais de Gestão Integrada de Resíduos Sólidos, 2.325 municípios declararam a sua conclusão, o que corresponde a $42 \%$ dos municípios e 52\% da população, o que em termos populacionais representa 107 milhões de habitantes.

Figura 2: Município que declararam possuir Plano de Gestão Integrada de Resíduos Sólidos, 2015.

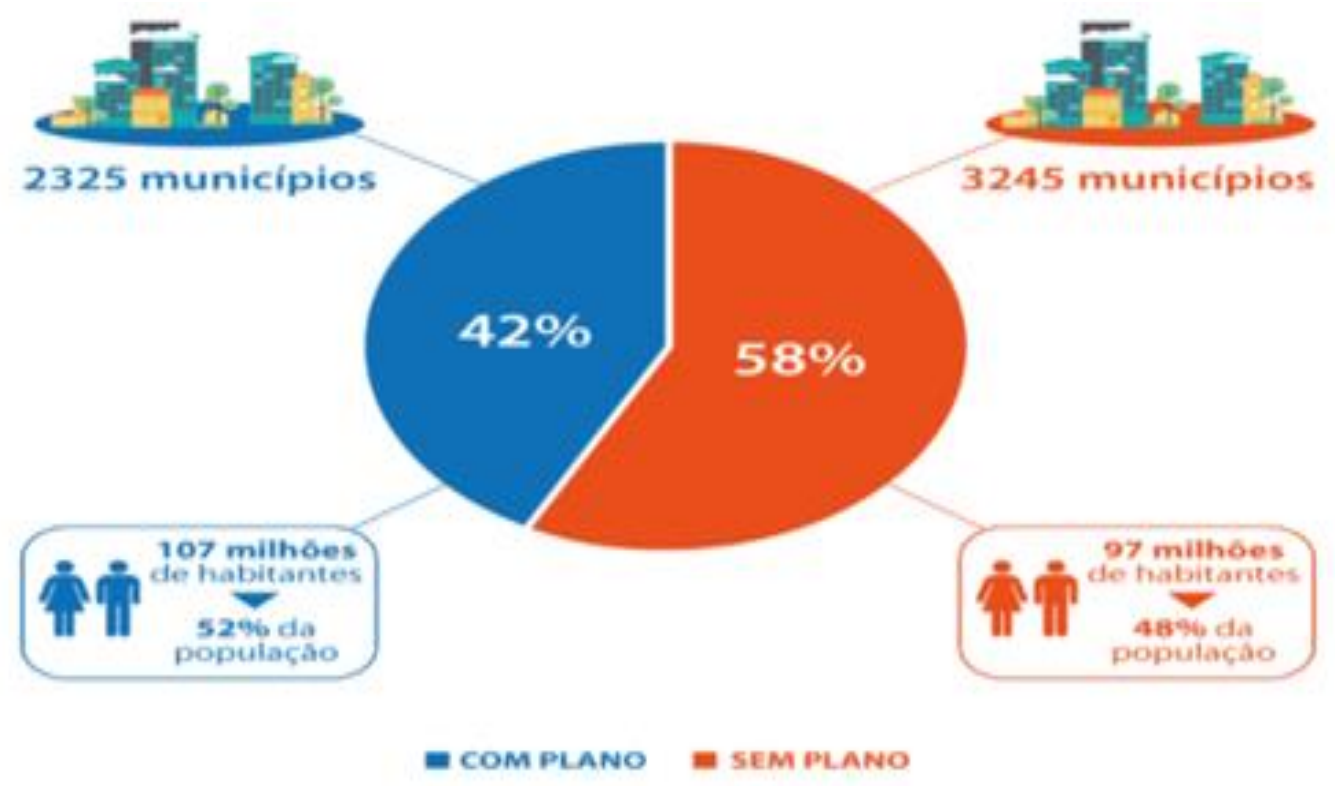

Fonte: MMA, 2015.

O Estudo Técnico sobre o diagnóstico nacional da Gestão Municipal de Resíduos Sólidos da Confederação Nacional dos Municípios - CNM (2015), realizado em 4.193 Municípios, ou seja, em $75 \%$ da totalidade deste ente federativo, destacou que 1.520 Municípios informaram possuir o Plano Municipal de Gestão Integrada de Resíduos Sólidos, 1.838 estavam em processo de elaboração, 807 não iniciaram e 28 não responderam o que correspondeu respectivamente a $36,3 \%, 43,8 \%, 19,2 \%$ e $0,7 \%$.

Figura 3: Situação dos Planos de Gestão Integrada de Resíduos Sólidos dos municípios, 2015. 


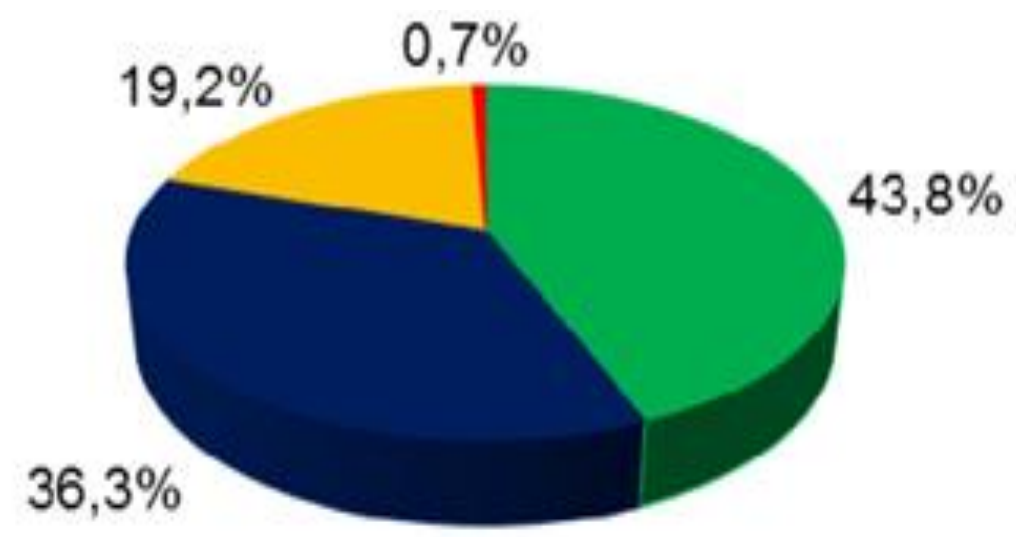

\section{Em elaboração Finalizado \\ Năo Iniciou não responderam}

Fonte: CNM, 2015.

De acordo com o Sistema Nacional de Informações sobre Saneamento SNIS (2016), do qual 3.670 municípios participaram da coleta, ou seja, 65,9\% do total do País, diagnosticou que 1.553 municípios elaboraram o Plano Municipal de Resíduos Sólidos.

O relatório do CGU (2016) apontou que a partir de 2010 recursos da ordem de 47 milhões foram disponibilizados para repasse a Estados, Municípios e consórcios públicos, com o objetivo de apoiar a elaboração dos planos estaduais, intermunicipais e municipais de resíduos sólidos, principalmente, por meio de contratos de repasse operados pela Caixa Econômica Federal (CEF). No entanto, nas operações contratadas com essa finalidade, foi verificada demora na conclusão dos objetos e a existência de operações que sequer iniciaram a execução.

Coadunamos com análise realizada pelo CGU (2016), quando afirmou que o Governo Federal contribuiu para a elaboração dos Planos de Resíduos Sólidos, por meio do aporte de recursos aos Estados, aos Municípios e aos consórcios em exercícios passados, mas os avanços não atingiram a meta de elaboração dos planos de resíduos sólidos, em função de variados aspectos, entre os principais destacamos: as deficiências técnicas, econômicas e gerenciais dos municípios, a escassez de recursos orçamentários e a descontinuidade desses aportes.

O ponto a marcar é que, sem o Plano Nacional de Resíduos Sólidos, perdeuse o referencial jurídico para a aplicação da PNRS, pois se a instância superior que regulamenta todas as outras não cumpre os dispositivos para a execução da lei a 
legitimidade para exigir e cobrar ações concretas dos Estados e, principalmente, dos municípios, que possuem deficiências de recursos humanos e menor capacidade financeira, técnica e operacional, se esfacela.

Outro aspecto importante refere-se à hierarquia constitucional brasileira, na qual há um poder constituinte originário que é a nascente de todo o ordenamento jurídico.

Sendo assim, quando o poder central não concluiu o seu plano, os Estados e os Municípios além de ficarem sem referência para produzir os seus e, consequentemente, para o estabelecimento das suas metas, diretrizes e indicadores, poderão ter que alterá-los, pois como há uma superioridade hierárquica do nacional sobre as demais leis e normas os referidos planos não poderão apresentar incompatibilidades em relação aos objetivos e metas traçados pelo futuro Plano Nacional de Resíduos Sólidos.

A ausência de um Plano Nacional e como desdobramento de Planos Estaduais e Municipais, dificultam a construção de um diagnóstico nacional sobre o cenário dos resíduos sólidos, a avaliação da implantação, operacionalização, fiscalização e monitoramento da política, bem como o controle social em relação à ação estatal, visto que não estão delineadas as ações necessárias a serem tomadas pelas três esferas de governo em relação às diretrizes, objetivos e metas da PNRS.

A elaboração dos Planos Estaduais e Municipais de Resíduos Sólidos é condicionante, conforme determinou a PNRS, para que os entes federativos tenham acesso a recursos da União. Talvez, até por isso, e para cumprir determinações legais no âmbito de gestão dos resíduos, que alguns municípios possuem plano de resíduos de fachada, que existem enquanto arcabouço legal, mas que na realidade não instrumentalizam a política.

Tal fato é facilitado pela falta de rotinas de aferição da qualidade dos planos elaborados e pela ausência de controle quanto à efetiva implantação das ações previstas em tais instrumentos de planejamento.

Diante do exposto, como estabelecer diretrizes, prioridades, metas e indicadores de sustentabilidade na gestão de resíduos sólidos para os Estados e os Municípios se o Plano Nacional de Resíduos, um dos principais instrumentos da Política Nacional de Resíduos Sólidos a ser elaborado pela União mediante processo de mobilização e participação social, incluindo a realização de audiências e consultas públicas recicláveis não foi finalizado? 
Indagamos ainda se diante da não continuidade dos aportes de recursos da União para os Municípios para a elaboração dos planos de resíduos e da escassez de recursos orçamentários e financeiros no âmbito municipal não seria a determinação de que elaboração dos planos de resíduos sólidos seja condição sine quo non para que os municípios tenham acesso a recursos da União destinados à gestão de resíduos sólidos um obstáculo à execução da própria PNRS?

A Política Nacional de Resíduos Sólidos propôs uma visão sistêmica na gestão dos resíduos sólidos que considere as variáveis ambiental, social, cultural, econômica, tecnológica e de saúde pública.

Nela foi definido que o Governo Federal atuará em regime de cooperação com as diferentes esferas do poder público, o setor empresarial e demais segmentos da sociedade, estabelecendo um conjunto de princípios, objetivos, instrumentos, diretrizes, metas e ações como forma de minimizar os impactos socioambientais decorrentes da gestão dos resíduos sólidos.

O Decreto 7.404/10, que regulamentou a Política Nacional de Resíduos Sólidos instituiu dois comitês, a saber: o Comitê Interministerial da Política Nacional de Resíduos Sólidos (CI) e o Comitê Orientador para Implantação de Sistemas de Logística Reversa (Comitê Orientador).

A despeito de estes comitês serem importantes instrumentos para a execução da Política Nacional de Resíduos Sólidos, ambas as decisões ficaram restritas ao âmbito do poder executivo federal, com a ausência de participação de sujeitos sociais importantes no processo decisório para a gestão dos resíduos.

Nesse contexto, os Estados, os Municípios, a iniciativa privada, a sociedade civil e os movimentos sociais organizados, em particular as cooperativas de catadores e catadoras de materiais recicláveis, não tiveram participação assegurada na articulação, discussão, formulação e execução de estratégias de questões pertinentes a PNRS, embora grande parte das atribuições nela previstas seja executada de forma descentralizada, principalmente quando se trata de resíduos sólidos urbanos.

Os municípios e seus representantes são os responsáveis pela execução da política de resíduos, e são eles que serão penalizados civil e criminalmente pela ausência dessa política pública. Já os catadores e as catadoras de materiais recicláveis são responsáveis por mais de $90 \%$ do processo de reciclagem, todavia 
a participação destes sujeitos ocorreu somente em etapas iniciais como em consultas públicas, ficando alheio ao processo decisório.

Como destacou o TCU (2016), essa postura dificultou agregar uma maior quantidade e qualidade de informações, prejudicando um sentido de pertencimento, de responsabilidade coletiva e de colaboração mútua. Além disso, contribuiu para provocar uma assimetria de informações entre os sujeitos que detêm o poder decisório e os que executam a política pública e, consequentemente, a tomada de decisões incompatíveis com as realidades locais, visto que o Brasil é um país com grandes diferenças regionais.

Diante dessa lacuna normativa, como pensar numa gestão integrada quando não há a efetiva participação dos sujeitos sociais estruturantes na operacionalização da política de resíduos?

Como apontamos anteriormente, a PNRS propôs uma visão sistêmica na gestão e no gerenciamento dos resíduos sólidos, porém como sinalizou o TCU (2016), o Governo Federal não possui uma estratégia de comunicação para a divulgação da PNRS, o que dificultou aos Municípios, sujeitos centrais na execução da política pública ter um conhecimento mais detalhado a respeito dos objetivos e das diretrizes da PNRS e, por desdobramento, do seu papel na implantação da política.

Como consequência, os gestores municipais por não possuírem uma visão global da política, focam a sua atenção no encerramento dos lixões por considerálo mais relevante e por medo de punição em âmbito civil e criminal, assim preterindo a elaboração dos planos de resíduos, a coleta seletiva com a inclusão social dos catadores e das catadoras de materiais recicláveis e a regulamentação da logística reversa.

Outra fragilidade para a consolidação da PNRS refere-se à dificuldade de monitoramento e transparência, em função da não implantação do Sistema Nacional de Informações sobre a Gestão dos Resíduos Sólidos - SINIR, que é um importante instrumento da Política Nacional de Resíduos Sólidos.

A Lei $n^{\circ}$ 12.305/10 estabeleceu que a União, os Estados, o Distrito Federal e os Municípios organizarão e manterão o SINIR de forma conjunta e articulada com o Sistema Nacional de Informações sobre Meio Ambiente - SINIMA e o Sistema Nacional de Informações sobre Saneamento Básico - SINISA, atual SNIS coordenado pelo Ministério das Cidades. 
O Art. $71^{\circ}$ do Decreto $\mathrm{n}^{\circ} 7.404 / 10$ definiu como finalidade do SINIR coletar e sistematizar dados relativos à prestação dos serviços públicos e privados de gestão e de gerenciamento de resíduos sólidos, inclusive dos sistemas de logística reversa implantados, promover o adequado ordenamento para a geração, armazenamento, sistematização, compartilhamento, acesso e disseminação dos dados e informações classificando-os de acordo com a sua importância e confidencialidade, em conformidade com a legislação vigente e disponibilizar estatísticas, indicadores e outras informações relevantes, inclusive visando à caracterização da demanda e da oferta de serviços públicos de gestão e gerenciamento de resíduos sólidos.

Além dessas finalidades, o SINIR deveria permitir e facilitar o monitoramento, a fiscalização e a avaliação da eficiência da gestão dos resíduos sólidos nos diversos níveis, possibilitar a avaliação dos resultados, dos impactos e o acompanhamento das metas dos planos e das ações de gestão e de gerenciamento de resíduos sólidos nos diversos níveis, informar à sociedade sobre as atividades realizadas na implantação da PNRS, disponibilizar periodicamente à sociedade o diagnóstico da situação dos resíduos sólidos no País por meio do Inventário Nacional de Resíduos Sólidos e agregar as informações sob a esfera de competência da União, dos Estados, do Distrito Federal e dos Municípios.

O SINIR deveria ter sido implantado até o final de 2012, contendo as informações do Cadastro Nacional de Operadores de Resíduos Perigosos, do Cadastro Técnico Federal de Atividades Potencialmente Poluidoras ou Utilizadoras de Recursos Ambientais, do Cadastro Técnico Federal de Atividades e Instrumentos de Defesa Ambiental, dos órgãos públicos competentes para a elaboração dos planos de resíduos sólidos referidos no art. 14 da Lei n ${ }^{\circ} 12.305$, de 2010, do Sistema Nacional de Informações em Saneamento Básico - SINISA, no que se refere aos serviços públicos de limpeza urbana e manejo de resíduos sólidos e dos demais sistemas de informações que compõem o Sistema Nacional de Informações sobre Meio Ambiente - SINIMA.

Todavia, o relatório do TCU (2016) apontou que o sistema não se encontrava em funcionamento até o final de 2015, o que impactou negativamente no monitoramento da PNRS, dificultando identificar as fragilidades, obstáculos, desafios e resultados, além de prejudicar a transparência e o controle pela 
sociedade, que se ressente de informações fidedignas e atualizadas que lhes permitam acompanhar e cobrar a implantação da PNRS.

Já o relatório da CGU (2016), com a finalidade de avaliar a atuação do Ministério do Meio Ambiente e do Ministério das Cidades no cumprimento da meta de eliminação dos lixões, destacou que a versão do SINIR não atendeu ao previsto no Decreto $n^{\circ} 7.404 / 2010$.

Ante essa realidade, como pensar na efetividade da PNRS sem um sistema dinâmico com o objetivo de disponibilizar as estatísticas e os indicadores, visando à caracterização da demanda e da oferta de serviços públicos de gestão e gerenciamento de resíduos sólidos, de modo a permitir seu monitoramento?

Como proporcionar à sociedade transparência e, consequentemente, a efetivação do controle social, bem como a inclusão não subalternizada dos catadores e das catadoras de materiais recicláveis sem a consolidação do SINIR?

A PNRS definiu a destinação final adequada como sendo a destinação de resíduos que inclui a reutilização, a reciclagem, a compostagem, a recuperação e o aproveitamento energético ou outras destinações admitidas pelos órgãos competentes do Sistema Nacional do Meio Ambiente (SISNAMA), do Sistema Nacional de Vigilância Sanitária (SNVS) e do Sistema Unificado de Atenção à Sanidade Agropecuária (SUASA), observando normas operacionais específicas para evitar danos ou riscos à saúde pública e à segurança e a minimizar os impactos ambientais adversos.

A destinação final adequada resíduos sólidos traria um conjunto de benefícios para a sociedade e para o meio ambiente como a diminuição da poluição do solo, da água e do ar, a perda de ecossistemas e de sua biodiversidade, a prevenção de enchentes, a economia de energia e de água e o aumento do nível de proteção da saúde pública.

Além desses benefícios, haveria a diminuição dos custos da produção, a reutilização e o uso de recicláveis, a melhoria da limpeza urbana e higiene da cidade, a redução de custos com o envio de resíduos ao aterro sanitário proporcionando o aumento de sua vida útil, o aumento do ICMS Ecológico, a eliminação dos passivos socioambientais, o atendimento aos princípios da Lei $\mathrm{n}^{\circ}$ 12.305/10 e a geração de empregos e renda por meio da inclusão social dos catadores e catadoras de materiais recicláveis. 
Para realizá-la, além de vontade política, seria necessária uma avaliação da viabilidade econômica, um diagnóstico socioeconômico da população e da situação atual dos resíduos sólidos, com estudo gravimétrico, um planejamento com estratégias para implantação e monitoramento das ações, um programa de capacitação dos profissionais envolvidos em todas as etapas do processo operacional e de um programa de educação ambiental junto à comunidade local, mostrando a importância da gestão integrada dos resíduos sólidos, em particular da reciclagem e da coleta seletiva, para a preservação ambiental e para a melhoria das condições de vida da população, em particular dos catadores e das catadoras de materiais recicláveis.

De acordo com a PNRS, um dos principais instrumentos para o fortalecimento da reciclagem é a coleta seletiva, isto é, a coleta diferenciada de resíduos previamente separados segundo a sua constituição, com vistas a atingir a meta de disposição final ambientalmente adequada dos rejeitos.

O sistema de coleta seletiva, que é uma obrigação dos municípios, deve ser implantado pelo titular do serviço público de limpeza urbana e manejo de resíduos sólidos, que em sua área de abrangência definirá os procedimentos para o acondicionamento adequado e disponibilização dos resíduos sólidos, estabelecendo, no mínimo, a separação de resíduos secos e úmidos de modo a priorizar a participação de cooperativas ou de outras formas de associação de catadores e catadoras de materiais reutilizáveis e recicláveis constituídas por pessoas físicas de baixa renda.

O PNSB de 2008 afirmou que 994 municípios da totalidade dos 5.564 possuíam a coleta seletiva, sendo a maior presença nas regiões Sul e Sudeste e a menor no Norte.

Para o IPEA (2010), apenas 2,4\% de todo o serviço de coleta de resíduos sólidos urbanos no Brasil foram realizados de forma seletiva, sendo todo o restante realizado como coleta regular, dificultando ou até mesmo impossibilitando a reutilização e a reciclagem de parte destes materiais.

Conforme sinalizou o IBGE (2011), dos 5.565 consultados foram identificados $32,3 \%$ que possuíam programa, projeto ou ação de coleta seletiva de resíduos em atividade, ao passo que em 3,3\% havia projeto piloto de coleta seletiva em área restrita e 2,5\% apresentavam coleta interrompida. 
Por sua vez, foram registrados $42,7 \%$ dos municípios sem programa, projeto ou ação de coleta seletiva de resíduos e 19,2\% sem programa, mas com projeto ou ação de coleta seletiva de resíduos em elaboração.

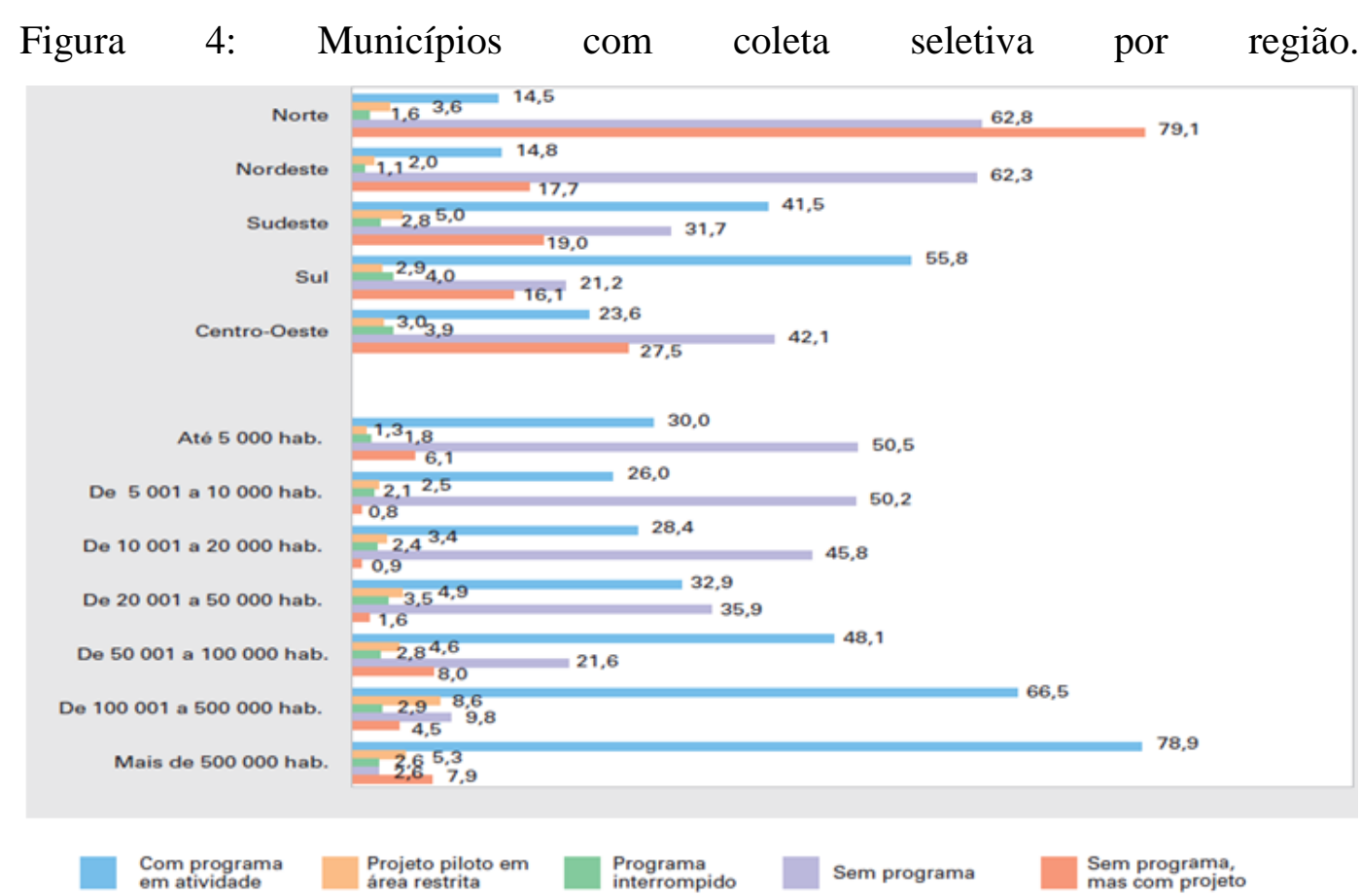

Fonte: IBGE, 2011.

O site (http://www.lixoes.cnm.org.br) da Confederação Nacional dos Municípios - CNM informou que, dos 5.570 municípios, 2.058 municípios possuíam alguma experiência de coleta seletiva, 2.069 não apresentavam nenhuma ação e 1.443 não informaram.

O SNIS (2016) apurou que a coleta seletiva era praticada em 1.215, ou seja, 33,1\% dos 3.670 municípios participantes da pesquisa. Se considerarmos os municípios que não informaram ao SNIS, o percentual desce para $21,8 \%$, o que representou uma queda pelo segundo ano consecutivo, num movimento contrário às diretrizes da PNRS. É importante ressaltar que, entre os 1.805 municípios que não participaram do SNIS, poderão existir aqueles que realizam a coleta seletiva. 
Tabela 1: Situação dos municípios quanto à coleta seletiva de recicláveis.

\begin{tabular}{|c|c|c|c|c|c|c|}
\hline \multirow{3}{*}{$\begin{array}{l}\text { Situação quanto à } \\
\text { existência de coleta } \\
\text { seletiva de recicláveis } \\
\text { secos (campo CSO01) }\end{array}$} & \multicolumn{3}{|c|}{$\begin{array}{c}\text { Quantidade de de } \\
\text { municípios }\end{array}$} & \multicolumn{3}{|c|}{ Em percentuais (\%) } \\
\hline & Ano & Ano & Ano & Ano & Ano & Ano \\
\hline & 2014 & 2015 & 2016 & 2014 & 2015 & 2016 \\
\hline $\begin{array}{l}\text { Municíios COM col. } \\
\text { seletiva }\end{array}$ & 1.322 & 1.256 & 1.215 & 23,7 & 22,5 & 21,8 \\
\hline $\begin{array}{l}\text { Municípios SEM col. } \\
\text { seletiva }\end{array}$ & 2.443 & 2.264 & 2.455 & 43,9 & 40,6 & 44,1 \\
\hline Sem informação & 1.805 & 2.050 & 1.900 & 32,4 & 36,8 & 34,1 \\
\hline Total & 5.570 & 5.570 & 5.570 & 100,0 & 100,0 & 100,0 \\
\hline
\end{tabular}

Fonte: SNIS, 2016.

O SNIS (2016) constatou que a Região Sul, com 52,1\%, isto é, 479 dos municípios dos 982, liderava em termos de realização da coleta seletiva, seguido da região Sudeste, com 42,5\%, da região Centro-Oeste, com $22,8 \%$ e do Nordeste e Norte com percentuais de 7,8\% e 5,9\%, respectivamente, sendo essas três últimas regiões com média inferior a nacional.

O SNIS (2016) destacou que no Nordeste, apesar de apenas 7,8\% dos municípios terem coleta seletiva, a população correspondente a essa região atinge mais da metade da população urbana $(56,6 \%)$ dos 871 municípios que participaram da pesquisa, o que também ocorreu na região Norte em função da presença significativa de grandes e médios municípios das referidas regiões.

O SNIS (2016) constatou que 1.215 municípios realizavam a coleta seletiva com quaisquer modalidades, contudo quando considerada a especificidade coleta seletiva porta-a-porta esse número se reduzia 14\%, ou seja, 1.045 municípios a executavam.

Ainda segundo diagnóstico do SNIS (2016), a região Sudeste possuía o maior valor absoluto de população atendida pela coleta seletiva porta-a-porta, com 29,1 milhões de habitantes. A região Sul foi a que mais se destacou em termos relativos à população atendida, cujo índice atingiu 64,3\% dos habitantes urbanos. 
Já nas regiões Norte e Nordeste os resultados chegaram, no máximo, a 6,2\% de cobertura da população urbana dos seus 1.092 municípios participantes.

A ABRELPE (2016), em sua pesquisa sobre o "Panorama dos Resíduos Sólidos no Brasil”, projetou que 3.878, isto é, $69,6 \%$ da totalidade dos 5.570 municípios realizavam a coleta seletiva.

Mesmo que a ABRELPE tenha considerado qualquer ação no interior do município como iniciativa de coleta seletiva, esse número se revelava extremamente discrepante em relação aos dados fornecidos pelo SNIS 2016.

Figura 5: Coleta seletiva nos municípios por regiões.

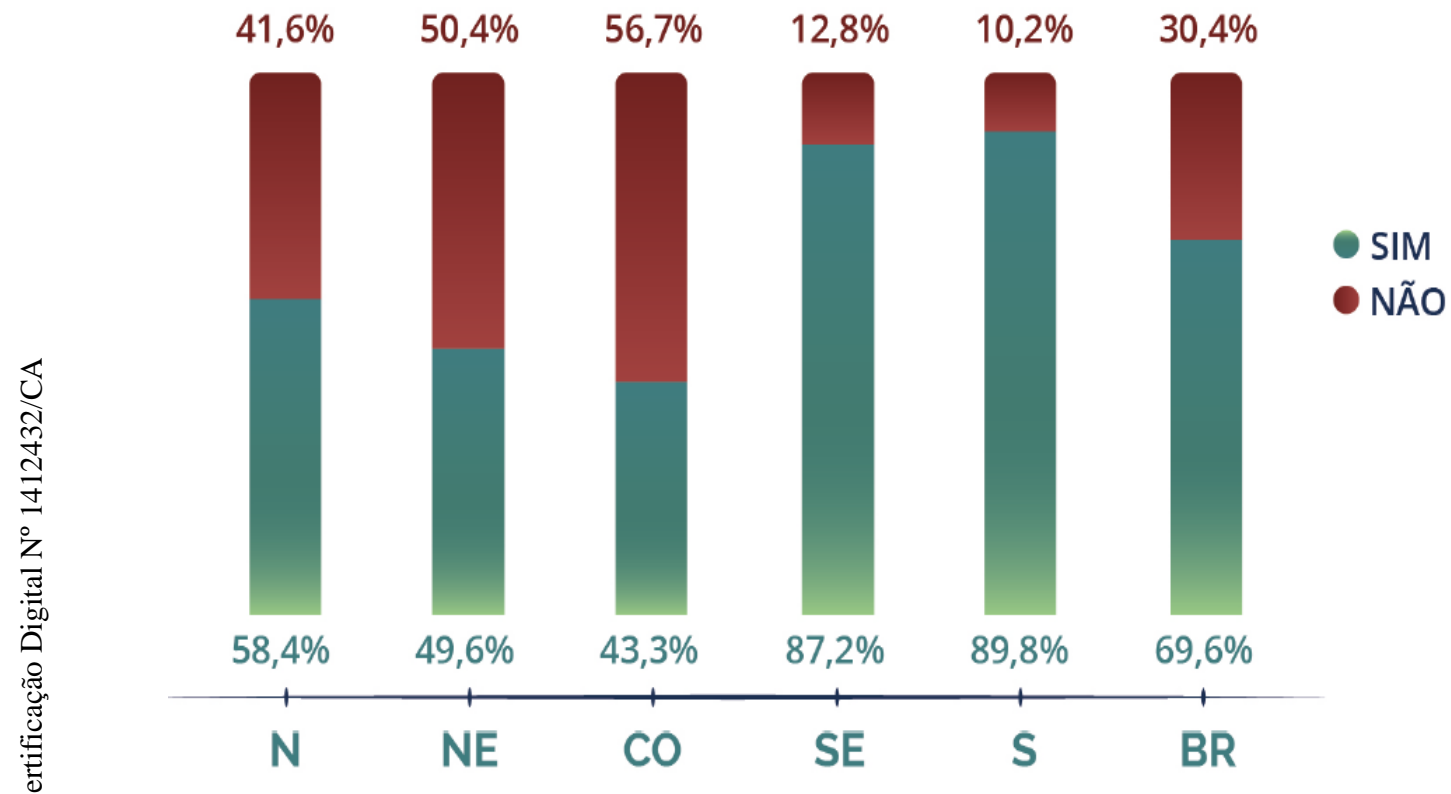

Fonte: ABRELPE, 2016.

A cadeia de reciclagem e, mais precisamente, da coleta seletiva, é extremamente complexa e envolve diversos sujeitos sociais com interesses distintos. Esta cadeia é composta pelo Estado, a indústria (privada e pública) de coleta de deposição de resíduos, os comerciantes intermediários do material, a indústria recicladora e transformadora e os catadores e as catadoras de materiais recicláveis.

Conforme sinalizou o IPEA (2013), neste arranjo verticalizado as indústrias recicladoras ocupam o "topo da pirâmide" da cadeia de valor, definindo os preços dos materiais, vindo abaixo delas os "intermediários", que na maioria das vezes organizam a infraestrutura com balança, prensa, triturador, caminhões, galpão e capital financeiro. Já na "base da pirâmide" encontram-se os catadores e as 
catadoras de materiais recicláveis, que trabalham diretamente na coleta, separação e triagem dos resíduos e são os responsáveis por quase $90 \%$ de todo o material que chega a ser reciclado no Brasil.

Apesar da sua importância para operacionalizar a indústria da reciclagem, estes profissionais apresentam carências econômicas, sociais e vulnerabilidades em diversas dimensões.

Pensando em reverter esse quadro, um amplo arcabouço jurídico para a inclusão social e econômica dos catadores de materiais recicláveis fora produzido.

A Lei Federal $n^{\circ} .11 .445 / 2007$, que dispõe sobre as diretrizes nacionais para o saneamento básico, estabeleceu alterações na Lei Federal nº. 8.666/1993, conhecida como a lei de licitações.

Nela foi inserido o inciso XXVII, em seu artigo 24, no qual ficou estabelecida a dispensabilidade de licitação na contratação para a coleta, processamento e comercialização de resíduos sólidos urbanos recicláveis ou reutilizáveis em áreas com sistema de coleta seletiva efetuado por associações ou cooperativas formadas exclusivamente por catadores e catadoras de materiais recicláveis, facilitando assim as condições para a contratação direta pelos municípios das organizações destes profissionais.

Coadunando com essa diretriz, a PNRS estabeleceu uma série de medidas para que os municípios priorizassem a integração das organizações de catadores e catadoras nas ações que envolvam a responsabilidade compartilhada pelo ciclo de vida dos produtos e a sua contratação direta, objetivando aumentar o processo de inclusão social.

Mas por quais motivos a contratação das cooperativas ocorreu somente em poucos municípios do Brasil, mesmo sendo vantajosa do ponto de vista técnico, econômico, ambiental e social para as prefeituras e para a sociedade?

Por que as prefeituras preferem pagar milhões às empresas privadas, muitas vezes destinando de forma inadequada os resíduos, a investirem numa prestação de serviço qualificada e que permite inclusão social e a distribuição de renda aos catadores? Qual o nó desse novelo?

A disposição final ambientalmente adequada foi definida na PNRS como a distribuição ordenada de rejeitos em aterros, quando esgotadas todas as possibilidades de tratamento e recuperação por processos tecnológicos disponíveis e economicamente viáveis, observando normas operacionais específicas de modo 
a evitar danos ou riscos à saúde pública e à segurança e a minimizar os impactos ambientais adversos. Isto é, a disposição dos resíduos é a etapa final da destinação adequada quando acabadas todas as possibilidades de tratamento dos resíduos.

Esta distinção de destinação e disposição final é fundamental para a correta aplicação da PNRS, porque enquanto a destinação adequada dos resíduos abarca todo o processo de tratamento e aproveitamento econômico dos resíduos, possibilitando a geração de emprego e renda e o fortalecimento da cidadania, a disposição final refere-se exclusivamente aos rejeitos, que são resíduos que não possuem mais nenhuma forma de serem aproveitados e que, portanto, deverão ser encaminhados aos aterros sanitários.

No Brasil existem três formas principais de disposição final de resíduos, a saber: o aterro sanitário, única forma permitida pela Lei $\mathrm{n}^{\circ} 12.305 / 10$, o aterro controlado e o lixão.

Segundo manual intitulado Mecanismo de Desenvolvimento Limpo (MDL) Aplicado à Redução de Emissões de Gases Gerados nas Áreas de Disposição Final de Resíduos Sólidos (2007), coordenado pelo Instituto Brasileiro de Administração Municipal - IBAM ${ }^{16}$, o aterro sanitário é uma obra de engenharia projetada a partir de critérios técnicos, cuja finalidade é garantir a disposição dos resíduos sólidos urbanos sem causar danos à saúde pública e ao meio ambiente, sendo assim considerada uma técnica eficiente e segura de disposição de resíduos sólidos.

Ainda segundo o manual, o aterro sanitário deverá ser elaborado em consonância com as normas preconizadas pela Associação Brasileira de Normas Técnicas - ABNT, que descreveu as diretrizes técnicas e elementos essenciais aos projetos, das quais merecem destaque os estudos preliminares caracterizando o município, a elaboração de um diagnóstico do gerenciamento de resíduos sólidos no local e as informações sobre a área adequada para a instalação, considerada a partir de critérios técnicos, ambientais, operacionais e sociais.

Além destes aspectos estruturantes, deverá apresentar e justificar os seus elementos como a drenagem das águas superficiais, a impermeabilização da camada superior e inferior, a drenagem e o tratamento dos lixiviados e dos gases, o plano de monitoramento para avaliar o impacto causado pela obra, os métodos

${ }^{16}$ O Instituto Brasileiro de Administração Municipal - IBAM é uma associação civil sem fins lucrativos, criada em $1^{\circ}$ de outubro de 1952 , com sede no Rio de Janeiro. 
de operação do aterro e as sugestões de uso futuro da área após encerramento das atividades, bem como o licenciamento ambiental do empreendimento exigido pelos órgãos ambientais.

O aterro controlado foi definido no manual como uma técnica de disposição de resíduos sólidos urbanos no solo, que utiliza princípios de engenharia para confinar os resíduos sólidos, cobrindo-os com uma camada de material inerte.

Apesar de ser uma técnica preferível ao lixão não é completamente adequada, tendo em vista prescindir da coleta e tratamento do chorume, assim como da drenagem e queima do biogás.

Já o lixão, segundo o referido manual, foi classificado como uma forma inadequada de disposição final de resíduos sólidos, caracterizada pela sua descarga sobre o solo, sem critérios técnicos e medidas de proteção ambiental ou à saúde pública.

Esse tipo de disposição que descarrega in natura os rejeitos acarretam problemas de saúde pública, com a proliferação de vetores de doenças por meio de moscas, baratas, ratos e mosquitos; ambientais com o aumento das emissões de gases de efeito estufa, a poluição do solo e das águas superficiais e subterrâneas pelo chorume produzido pela decomposição dos resíduos, aumento de incêndios causados pelos gases, ocasionando impactos nos ecossistemas e na biodiversidade e a geração de odores desagradáveis.

Além de problemas jurídicos no âmbito civil e criminal em função dos passivos socioambientais decorrentes da disposição inadequada dos resíduos; econômicos, em decorrência de pesadas multas efetuadas pelos órgãos de fiscalização ambiental; de insegurança aérea, pelo risco de graves acidentes aéreos; social pelas condições de vulnerabilidades na qual os catadores e as catadoras de materiais recicláveis são submetidos.

O PNSB, de 2008, revelou que em termos de disposição final de resíduos, os lixões ocupavam o primeiro lugar, correspondendo a 50,8\% dos 5.564 municípios, sendo acompanhado pelo aterro sanitário com $27,7 \%$ e o aterro controlado com 22,1\%. Levando em conta que a PNRS só considerou o aterro sanitário como destinação adequada, o PNSB 2008 registrou que 73,3\% dispunham o resíduo de forma inadequada. 
Tabela 2: Destinação final dos resíduos, por unidades de destino dos resíduos no Brasil - 1989 - 2008.

\begin{tabular}{|c|c|c|c|}
\hline \multirow{2}{*}{ Ano } & \multicolumn{3}{|c|}{ Destino final dos residuos sólidos, por unidades de destino dos residuos (\%) } \\
\hline & Vazadouro a céu aberto & Aterro controlado & Aterro sanitário \\
\hline 1989 & & & 1,1 \\
\hline 2000 & & & 17,3 \\
\hline 2008 & & & 27,7 \\
\hline
\end{tabular}

Fonte: IBGE, 2008.

As regiões Norte e Nordeste, de acordo com o PNSB 2008, apresentaram os maiores índices de encaminhamento dos resíduos para os lixões: de 89,3\% e $85,5 \%$, respectivamente. Já as regiões Sudeste e Sul apresentaram as menores proporções de disposição em lixões, equivalentes a 18,7\% e 15,8\%. Na região Sul, o destaque foi o Estado de Santa Catarina que enviou 2,0\% para os lixões.

Segundo o site (http://www.lixoes.cnm.org.br) da CNM no ano de 2015, dos 5.570 municípios 845 dispunham em aterros sanitários, 1.775 tinham como disposição final os aterros controlados e os lixões e 2.950 não declararam a forma de disposição final.

Já o SNIS (2016) apresentou o quadro a seguir.

Tabela 3: Quantidade de unidades de processamento de RSU.

\begin{tabular}{|c|c|c|c|c|c|c|}
\hline \multirow{3}{*}{$\begin{array}{l}\text { Tipo de unidade de } \\
\text { processamento (-) }\end{array}$} & \multicolumn{5}{|c|}{$\begin{array}{c}\text { Qted. de unidades de processamento } \\
\text { por regibo }\end{array}$} & \multirow{2}{*}{$\begin{array}{l}\text { Total } \\
\text { de } \\
\text { unida- } \\
\text { des }\end{array}$} \\
\hline & Norte & Nordex & Sudeste & sut & $\begin{array}{l}\text { Centro } \\
\text {-Oeste }\end{array}$ & \\
\hline & (unies.) & (conid.) & (conid) & (cunid.) & (umiel.) & (cuniel) \\
\hline $2.4 \times 30$ & 160 & 705 & 108 & 39 & 191 & 1.203 \\
\hline Aterro Controlado & 30 & 48 & 459 & 49 & 42 & 628 \\
\hline Aterro saniedrio & 18 & 57 & 366 & 212 & 34 & 687 \\
\hline $\begin{array}{l}\text { Unidade de triagem (ealplo ou } \\
\text { usina) }\end{array}$ & 21 & so & 467 & 322 & 46 & 896 \\
\hline $\begin{array}{l}\text { Un. de compostacem (pátio ou } \\
\text { usina) }\end{array}$ & 1 & 3 & 51 & 10 & 2 & 67 \\
\hline $\begin{array}{l}\text { Unidade de transbordo } \\
\text { (RDOARPU) }\end{array}$ & 1 & 6 & $5 \mathrm{~s}$ & 46 & 10 & 121 \\
\hline $\begin{array}{l}\text { Un. de tratamento por } \\
\text { incinerasbo }\end{array}$ & $\mathbf{0}$ & 5 & 10 & 3 & 1 & 19 \\
\hline $\begin{array}{l}\text { Unidade de manejo de ealhadas } \\
\text { opodas }\end{array}$ & 1 & 6 & 10 & 15 & $\mathbf{0}$ & 32 \\
\hline $\begin{array}{l}\text { Vala especifice de RSS (res. dos } \\
\text { serv savide) }\end{array}$ & 5 & 6 & 6 & $\circ$ & $\mathbf{3}$ & 20 \\
\hline $\begin{array}{l}\text { Un. de tratamento por micro- } \\
\text { ondes ou autoclave }\end{array}$ & 1 & 2 & 3 & 6 & $\circ$ & $1 . \mathrm{a}$ \\
\hline $\begin{array}{l}\text { Queima em formo de qualquer } \\
\text { tipo }\end{array}$ & 2 & o & o & $\circ$ & 1 & 3 \\
\hline Aterro industrial & $\mathbf{x}$ & o & 2 & $\mathbf{x}$ & $\circ$ & 4 \\
\hline $\begin{array}{l}\text { Área de transbordo e triagem de } \\
\text { RCC-I evolumosos (ATT) }\end{array}$ & 1 & 2 & 24 & 20 & $\mathbf{0}$ & 37 \\
\hline 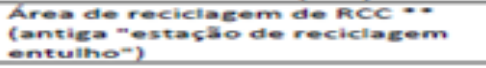 & o & 2 & 28 & 5 & o & 24 \\
\hline $\begin{array}{l}\text { Aterro de PCC }-1 \text { (antieo -at. } \\
\text { imertes') }\end{array}$ & o & 3 & 37 & $\mathbf{3}$ & 6 & ss \\
\hline Outro & 3 & 4 & 124 & 20 & 4 & 155 \\
\hline \multirow{2}{*}{ Total - 2016} & 235 & 898 & 1.739 & 757 & 340 & 3.969 \\
\hline & 5,926 & $22,6 \%$ & 43,02 & $19,1 \%$ & $3,6 \%$ & 100,006 \\
\hline
\end{tabular}

Fonte: SINIS, 2016.

Para o SNIS (2016) foi possível inferir a destinação final de $85,2 \%$ da massa coletada no País. DesSa massa total coletada, estimada em 58,9 milhões de toneladas, desprezando-se, para efeito de segurança, a parcela que foi recuperada, 
apurou-se que 59\% foram dispostas em aterros sanitários, 9,6\% em aterros controlados, 10,3\% em "lixões" e 3,4\% encaminhados para unidades de triagem e de compostagem, restando então a parcela de $17,7 \%$ sem informação, a qual se referia sobretudo aos pequenos municípios até 30 mil habitantes.

Segundo o SNIS (2016), admitindo-se que 3/4 desta "massa sem informação" foi encaminhada para lixões, pode-se dizer que $66,8 \%$ da massa total coletada no País foram dispostas de forma adequada, em aterros sanitários, sendo o restante distribuído em lixões e aterros controlados.

O SNIS destacou a continuidade do contraste entre as regiões, nas quais as melhores situações foram encontradas nas regiões Sul e Sudeste.

Ressaltou também que Santa Catarina foi o Estado que melhor destinou os resíduos, com pelo menos $82 \%$ de seus municípios utilizando aterros sanitários, não havendo nenhum registro de lixão dentre os 242 municípios que responderam o SNIS de um total de 295.

Já na região Sudeste o destaque foi para o Estado do Espírito Santo, que tem 78 (setenta e oito) municípios. Destes, 75 (setenta e cinco) responderam o SNIS e destes 58 (cinquenta e oito), ou seja, no mínimo 74\% do total de municípios afirmou enviar seus resíduos para aterros sanitários. Do montante respondente dos 75 (setenta e cinco) apenas 04 (quatro) municípios utilizaram o lixão.

Segundo dados da ABRELPE (2016), a disposição final adequada para aterros sanitários foi de $58,4 \%$ e a disposição inadequada correspondeu a $41,6 \%$ dos resíduos coletados em 2016, sendo 24,2 \% dos resíduos para os aterros controlados e 17,4\% para os lixões. Em termos de toneladas, os gráficos abaixo demonstram o seu quantitativo dia e ano em relação ao tipo de disposição final.

Figura 6: Tipo de disposição final no Brasil (t/dia).

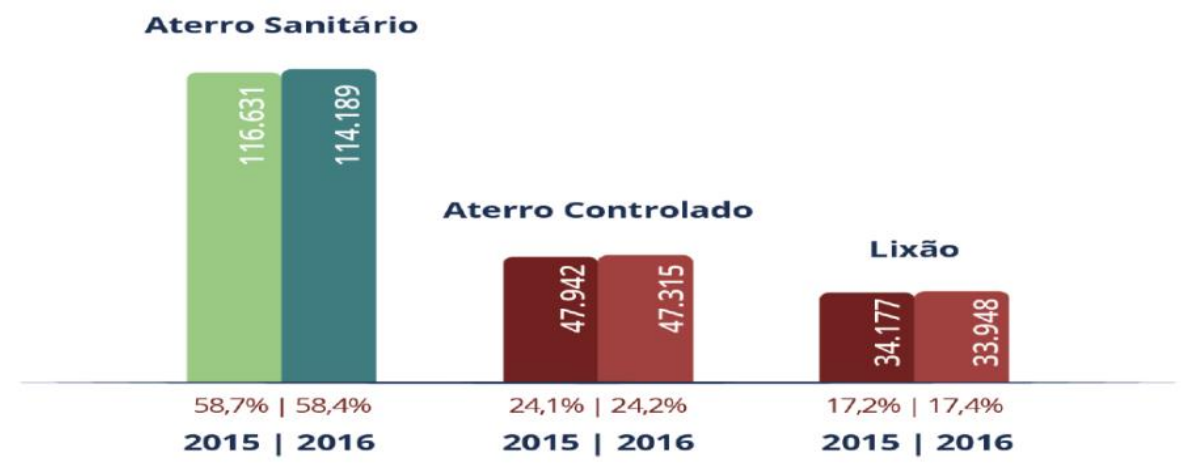

Fonte: ABRELPE, 2016. 
Figura 7: Tipo de disposição final no Brasil (t/ano).

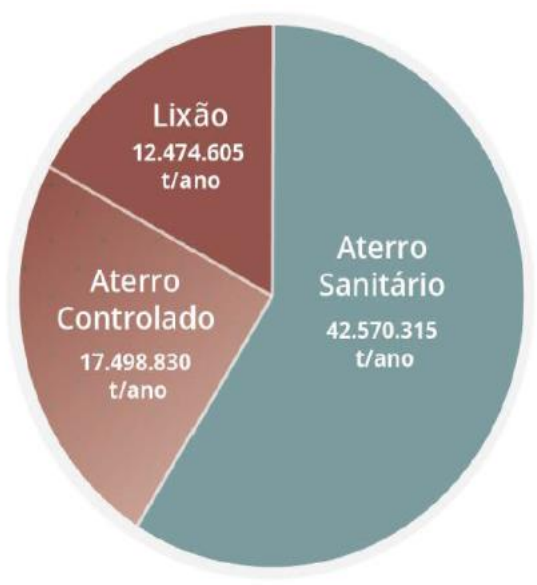

2015

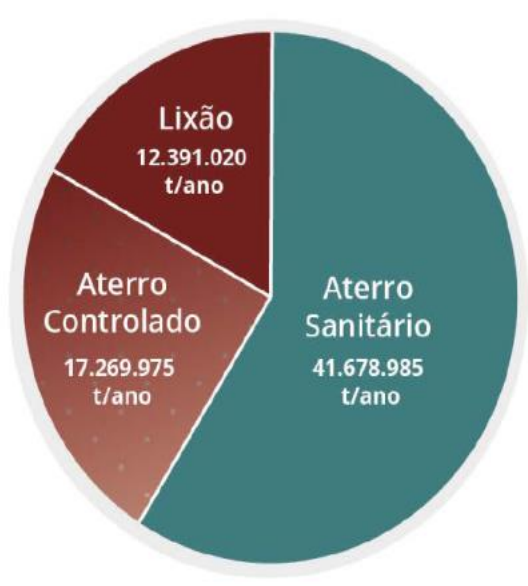

2016

Fonte: ABRELPE, 2016.

Em relação à disposição final por municípios a ABRELPE (2016) evidenciou que 2.239 encaminham os resíduos para os aterros sanitários, sendo 822 na Região Sudeste, 706 no Sul, 458 no Nordeste, 161 no Centro-Oeste e 92 no Norte.

No que tange à disposição inadequada dos resíduos, que é uma triste constatação em todo território nacional, foram identificados 1.772 municípios que dispunham em aterros controlados, dos quais 112 no Norte, 148 no Centro-Oeste, 368 no Sul, 500 no Nordeste e 644 no Sudeste. Já dos 1.559 que dispunham em lixões, foram encontrados 836 no Nordeste, seguidos de 246 no Norte, 202 no Sudeste, 158 no Centro-Oeste e 117 no Sul.

$\mathrm{Na}$ PNRS, em seu Art. 54 ${ }^{\circ}$, ficou estabelecido que a disposição final ambientalmente adequada dos rejeitos deveria estar implantada até o dia 02 de agosto de 2014. Entretanto, quatro anos após o prazo estabelecido e oito anos após promulgação da lei, os Estados e os Municípios enfrentam problemas para a disposição ambientalmente adequada de resíduos e para o encerramento dos aterros controlados e lixões.

Mesmo sendo um problema de grande magnitude, erradicar os lixões é uma tarefa difícil, necessitando de um complexo arranjo institucional, de um corpo normativo consistente, de vontade política, de planejamento com um processo de avaliação, fiscalização, transparência e monitoramento, além de apoio social e recursos orçamentários e financeiros. 
A disposição final adequada dos resíduos e a erradicação dos aterros controlados e dos lixões são de competência exclusiva dos Municípios. Serão eles os punidos civil e criminalmente por não cumprirem a PNRS. Contudo, é importante destacar que todos os entes federativos descumprem a PNRS, inclusive a União, que ocupa o topo da hierarquia constitucional, possui maior parte da arrecadação do país, mas ainda não concluiu o Plano Nacional de Resíduos Sólidos.

Há que se ressaltar que no período de 2007 até 2014, embora tenha sido destinada uma autorização orçamentária na ordem de $\mathrm{R}$ \$ 268 milhões anuais para a gestão dos resíduos, a execução orçamentária alcançou pouco mais do que 5\%, ou seja, R\$ 6,9 milhões por ano em média.

Além desse aspecto, o TCU (2016) enfatizou que a temática de Resíduos Sólidos deixou de ser um programa no Plano Plurianual - PPA (2012 a 2015) para ser apenas um objetivo no PPA (2016 a 2019), indicando que esse assunto se encontrava fora da agenda política prioritária do Governo Federal.

Outra questão extremamente relevante a ser discutida em torno dos fechamentos dos lixões relaciona-se com a realidade dos catadores e das catadoras de materiais recicláveis.

Bastos (2015), em seu estudo, apontou para os estados de vulnerabilidade social que os catadores e as catadoras de materiais recicláveis do antigo lixão de Gramacho se encontravam submetidos. Entretanto, ressaltou que o fechamento desse, sem a incorporação efetiva destes profissionais no sistema de gestão de resíduos de forma justa e financeiramente sustentável piorará as já precárias condições de saúde, segurança e trabalho.

Bastos (2015) arguiu sobre a necessidade do fornecimento de recursos para a remuneração do trabalho, infraestrutura, capacitação e assistência técnica para a garantia de dignidade destes trabalhadores, pois caso isso não acontecesse os catadores e as catadoras dos lixões, além de perderem as suas referências laborais, continuarão desempregados e vivendo em condições mais precarizadas do que no passado, pois se antes o risco ambiental era iminente pela condição do trabalho, a situação de risco social se tornará total.

$\mathrm{Na}$ esteira dessa argumentação, questionamos se o fechamento dos lixões sem o apoio aos catadores e as catadoras de materiais recicláveis não seria uma 
forma de gestão ambiental que desconecta a sustentabilidade ambiental da sustentabilidade social?

Em outras palavras, pensar o fechamento dos lixões desconectado da sustentabilidade social não seria mais uma forma de reforçar as vulnerabilidades, as precariedades e a injustiça ambiental sobre este segmento social?

A PNRS estabeleceu a responsabilidade compartilhada pelo ciclo de vida dos produtos a ser implantada de forma individualizada e encadeada, abrangendo os fabricantes, importadores, distribuidores e comerciantes, os consumidores e os titulares dos serviços públicos de limpeza urbana e de manejo de resíduos sólidos objetivando compatibilizar interesses entre os agentes econômicos e sociais e os processos de gestão empresarial e mercadológica com os de gestão ambiental, desenvolvendo estratégias sustentáveis para minimizar o volume de resíduos sólidos e rejeitos gerados, bem como para reduzir os impactos causados à saúde humana e à qualidade ambiental decorrentes do ciclo de vida dos produtos.

Porém, a PNRS, como destacou o TCU (2015), não definiu claramente os responsáveis pelas etapas do ciclo de vida do produto relacionadas à destinação ambientalmente adequada, em particular sobre quem arcará com os custos em cada uma das fases, diferentemente do que ocorreu na Europa com a responsabilidade estendida do produtor. Tal fato tem acarretado um conjunto de conflitos socioambientais, particularmente na elaboração dos acordos setoriais no âmbito da logística reversa.

O Decreto 7.404/10 definiu a logística reversa como instrumento de desenvolvimento econômico e social caracterizado pelo conjunto de ações, procedimentos e meios destinados a viabilizar a coleta e a restituição dos resíduos sólidos ao setor empresarial, para reaproveitamento, em seu ciclo ou em outros ciclos produtivos, ou outra destinação final ambientalmente adequada, tendo como ferramentas para implantá-la e operacionalizá-la os regulamentos expedidos pelo Poder Público, os Termos de Compromisso e os acordos setoriais.

$\mathrm{O}$ acordo setorial foi definido como ato de natureza contratual firmado entre o Poder Público e o setor empresarial responsável pela produção, distribuição e comercialização de embalagens de papel e papelão, plástico, alumínio, aço, vidro, ou ainda pela combinação destes materiais, que assumem o compromisso nacional de cumprir metas anuais progressivas de reciclagem destas embalagens, visando à implantação da responsabilidade compartilhada pelo ciclo de vida do produto. 
De acordo com o trabalho Confederação Nacional dos Municípios - CNM (2015), a União instituiu como o sistema de logística reversa irá ocorrer em âmbito nacional, mas ficou a cargo do setor empresarial estruturá-lo e implantá-lo.

Para tanto, poderão ser adotados procedimentos de compra de produtos ou embalagens usadas e distribuição de postos de entrega de resíduos reutilizáveis e recicláveis, devendo ser priorizada, especialmente no caso de embalagens pósconsumo, a participação de cooperativas ou outras formas de associações de catadores e catadoras de materiais recicláveis ou reutilizáveis.

Segundo o Ministério do Meio Ambiente, em novembro de 2015 o Governo Federal assinou com representantes do setor empresarial e dos catadores e das catadoras de materiais recicláveis o acordo setorial para a logística reversa de embalagens em geral.

Ainda segundo o Ministério do Meio Ambiente, na fase inicial de implantação de 24 meses o sistema priorizaria o apoio às cooperativas de catadores e catadoras de materiais recicláveis e a instalação de pontos de entrega voluntária de embalagens em grandes lojas do comércio.

Passados mais de 02 anos do prazo como está o acordo setorial? Houve uma verdadeira inclusão dos catadores e das catadoras ou apenas uma pequena parcela de cooperativas foi incluída precariamente?

Como já explicitado, há uma diretriz que atribuiu a responsabilidade dos fabricantes, importadores, distribuidores e comerciantes em dar destinação ambientalmente adequada aos produtos e às embalagens, via logística reversa. Mas, na prática, quem faz esse serviço?

Segundo a CNM (2015), esse serviço é realizado pelos municípios, contudo não há remuneração do setor empresarial pelo trabalho pois ainda não houve nenhum acordo setorial nesse sentido. Sendo assim, há um claro descumprimento da PNRS.

Dito de outra forma, se o setor empresarial não executa a logística reversa como determinou a PNRS, nem efetua o pagamento para os municípios que realizam o serviço, nem tampouco contratou as cooperativas de catadores e de catadoras de materiais recicláveis por meio de acordo setoriais, como poderemos falar de responsabilidade compartilhada e logística reversa e da aplicação da PNRS? 
Aqui é relevante destacar que a logística reversa e a coleta seletiva, além de serem necessariamente complementares, apresentam semelhanças no sentido que ambas são relacionadas à implantação da responsabilidade compartilhada pelo ciclo de vida dos produtos, porém a primeira é uma responsabilidade do setor empresarial, enquanto a coleta seletiva é uma obrigação dos titulares dos serviços de manejo de resíduos sólidos, ou seja, do poder público.

Os dados acima descritos evidenciando as fragilidades, as contradições, os limites e as possibilidades para a implantação da PNRS auxiliarão na análise proposta no sentido de verificar, a partir do estudo no município do Arraial do Cabo, se a Política Nacional de Resíduos Sólidos contribui para efetiva inclusão social e emancipação econômica dos catadores e das catadoras de materiais recicláveis inseridos na gestão de resíduos ou se esse ordenamento jurídico que regula essa atividade econômica inclui precariamente esse segmento na gestão, reforçando as vulnerabilidades e os mecanismos de injustiça social. 


\section{O Município de Arraial do Cabo e a Política Nacional de Resíduos Sólidos}

No capítulo terceiro historicizamos a consolidação dos resíduos sólidos enquanto um problema ambiental, social, econômica, cultural e de saúde pública no mundo e no Brasil, dando ênfase à implantação das políticas públicas voltadas ao seu enfrentamento.

Mostramos a partir de uma revisão bibliográfica o processo de mudança de percepção em relação aos resíduos, que começou a ganhar centralidade principalmente com a Conferência Rio 92, quando se estabeleceu que o manejo, o tratamento e a disposição adequada dos mesmos se encontrava entre as questões mais relevantes para a manutenção da qualidade do meio ambiente e para que a sociedade alcançasse um crescimento ambientalmente saudável em todos os países.

Apresentamos também o desenvolvimento das políticas de resíduos sólidos no Brasil, que se consolidaram com a Lei ${ }^{\circ} 12.305 / 2010$, que instituiu a Política Nacional de Resíduos Sólidos, definindo os seus princípios, os objetivos, os instrumentos e as diretrizes relativas à gestão integrada e ao gerenciamento de resíduos sólidos. Entretanto, enfatizamos as suas fragilidades, contradições, limites e possibilidades.

No quarto capítulo analisaremos se a Política Nacional de Resíduos Sólidos contribui para a democrática inclusão social dos catadores e das catadoras de materiais recicláveis na gestão de resíduos ou se esse ordenamento jurídico que regula essa atividade econômica os inclui subalterna e precariamente, reforçando os processos de vulnerabilidades e de injustiças ambientais sobre esses trabalhadores.

Para tanto, a pesquisa qualitativa terá como fio condutor de análise um estudo de caso sobre a implantação da política de resíduos sólidos no município de Arraial do Cabo, no Estado do Rio de Janeiro, no período compreendido entre 2009 e 2018, atentando para o planejamento, a avaliação, a fiscalização, a transparência e o monitoramento das ações governamentais no que tange a gestão e ao gerenciamento de resíduos sólidos. 
Neste contexto, com a finalidade de empregar uma variedade de fontes de evidências, para ligar as questões levantadas, aos dados coletados e as conclusões propostas, tomaremos como suporte para a descrição e a interpretação da realidade social investigada a pesquisa bibliográfica sobre os resíduos sólidos e a Política Nacional de Resíduos Sólidos, a revisão documental com ênfase na Auditoria Governamental na Prefeitura de Arraial do Cabo realizada em 2012 pelo TCE/RJ para verificar as condições de organização e funcionamento dos serviços de limpeza urbana e manejo dos resíduos sólidos e na Ação Civil Pública ${ }^{\circ}$ 0000412-67.2007.8.19.0005, promovida pelo Ministério Público em face do município do Arraial do Cabo, a análise da legislação ambiental voltada para a gestão e o gerenciamento dos resíduos sólidos e as entrevistas semiestruturadas com os principais atores sociais responsáveis pela gestão dos resíduos, a saber: dirigentes e catadores e catadoras da Cooperativa de Coleta e Reciclagem da Costa do Sol; poder público, representado pela Secretaria Municipal de Ambiente e Fundação Municipal de Meio Ambiente, Pesquisa, Ciência e Tecnologia; dirigentes do Movimento Nacional dos Catadores - MNCR e do Movimento Nacional Eu Sou Catador de Materiais Recicláveis - MESC.

Mas antes de respondermos a este questionamento, iremos conhecer um pouco do município do Arraial do Cabo e da sua história na gestão dos resíduos sólidos.

\subsection{O município do Arraial do Cabo e o panorama dos resíduos sólidos antes e depois da Política Nacional de Resíduos Sólidos}

Arraial do Cabo, município do Estado do Rio de Janeiro, segundo o IBGE localiza-se na parte centro-sul do litoral brasileiro, próximo às coordenadas $23^{\circ} 44^{\prime} \mathrm{S}$ e $42^{\circ} 00^{\prime} \mathrm{W}$ na Região das Baixadas Litorâneas, que compreende os municípios de Araruama, Armação dos Búzios, Cabo Frio, Casimiro de Abreu, Iguaba Grande, Rio das Ostras, São Pedro da Aldeia, Saquarema e Silva Jardim.

Figura 8: Mapa do Brasil, do Rio de Janeiro e da Região das Baixadas Litorâneas. 


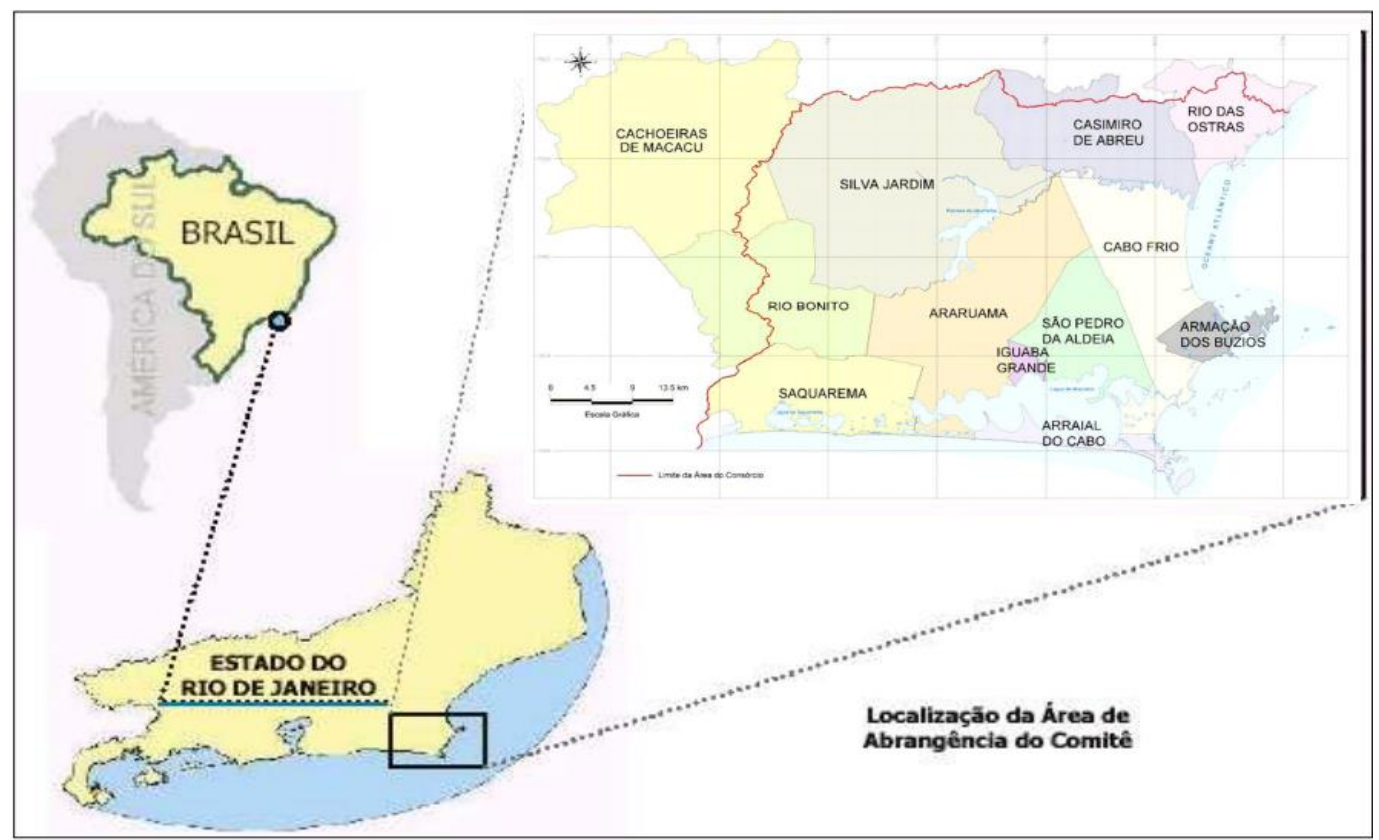

Fonte: Plano de Bacias - 2006.

O município fica localizado a uma distância de $158 \mathrm{~km}$ da capital do Estado, possui uma extensão territorial de $160,28 \mathrm{~km}^{2}$ e limita-se ao norte com os municípios de São Pedro D'Aldeia e Cabo Frio, a oeste com o município de Araruama, e ao sul leste com o Oceano Atlântico.

Figura 9: Localização de Arraial do Cabo e seus limites, localização do município no Estado do Rio de Janeiro e no Brasil e suas praias.

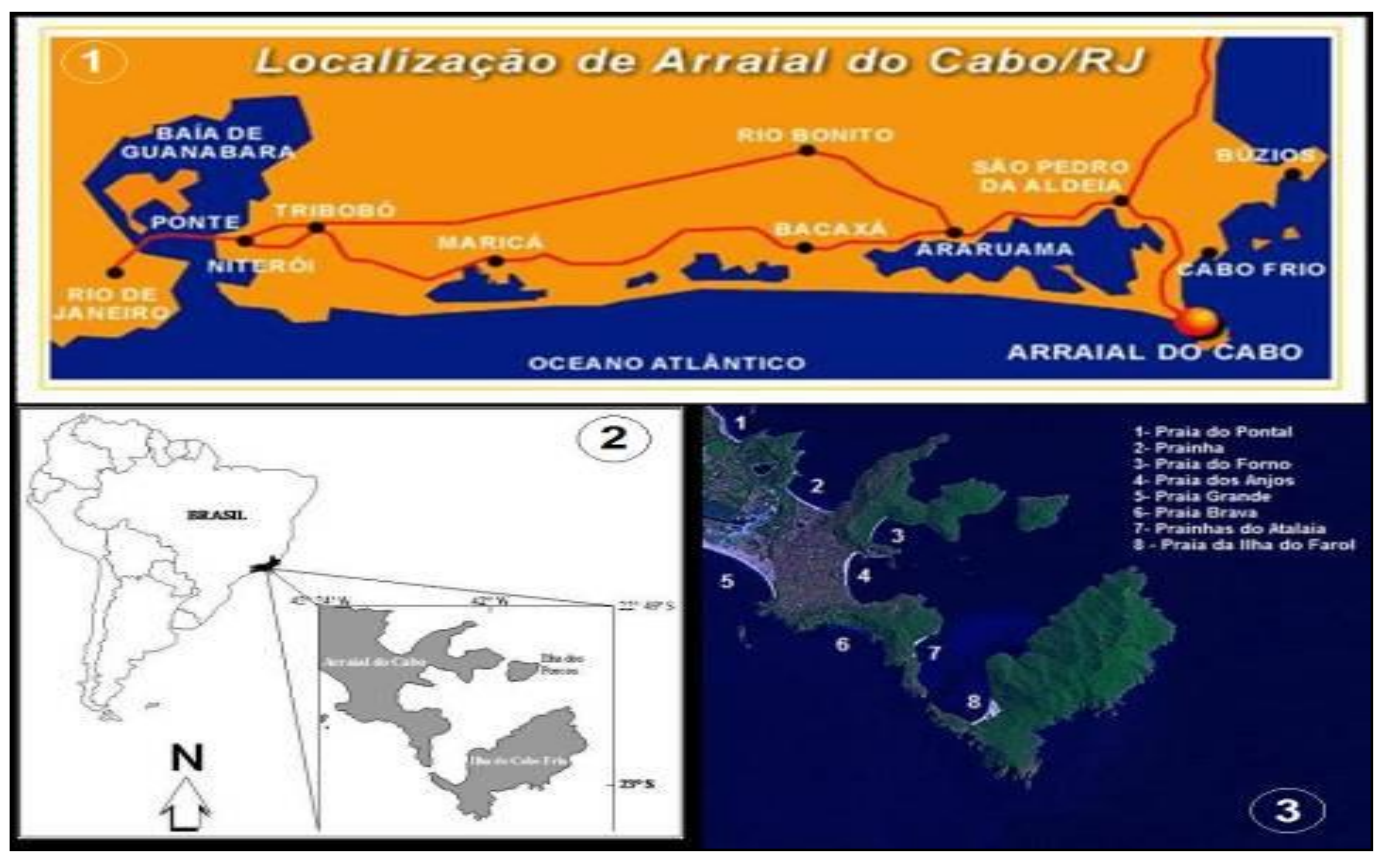

Fonte: Fundação Municipal de Meio Ambiente, Pesquisa, Ciência e Tecnologia, 2009. 
$\mathrm{O}$ acesso ao município ocorre pela RJ-140 ou pela RJ-102, que rodeia a Lagoa de Araruama, percorrendo a Restinga de Massambaba até Arraial do Cabo.

Figura 10: Acesso ao município de Arraial do Cabo.

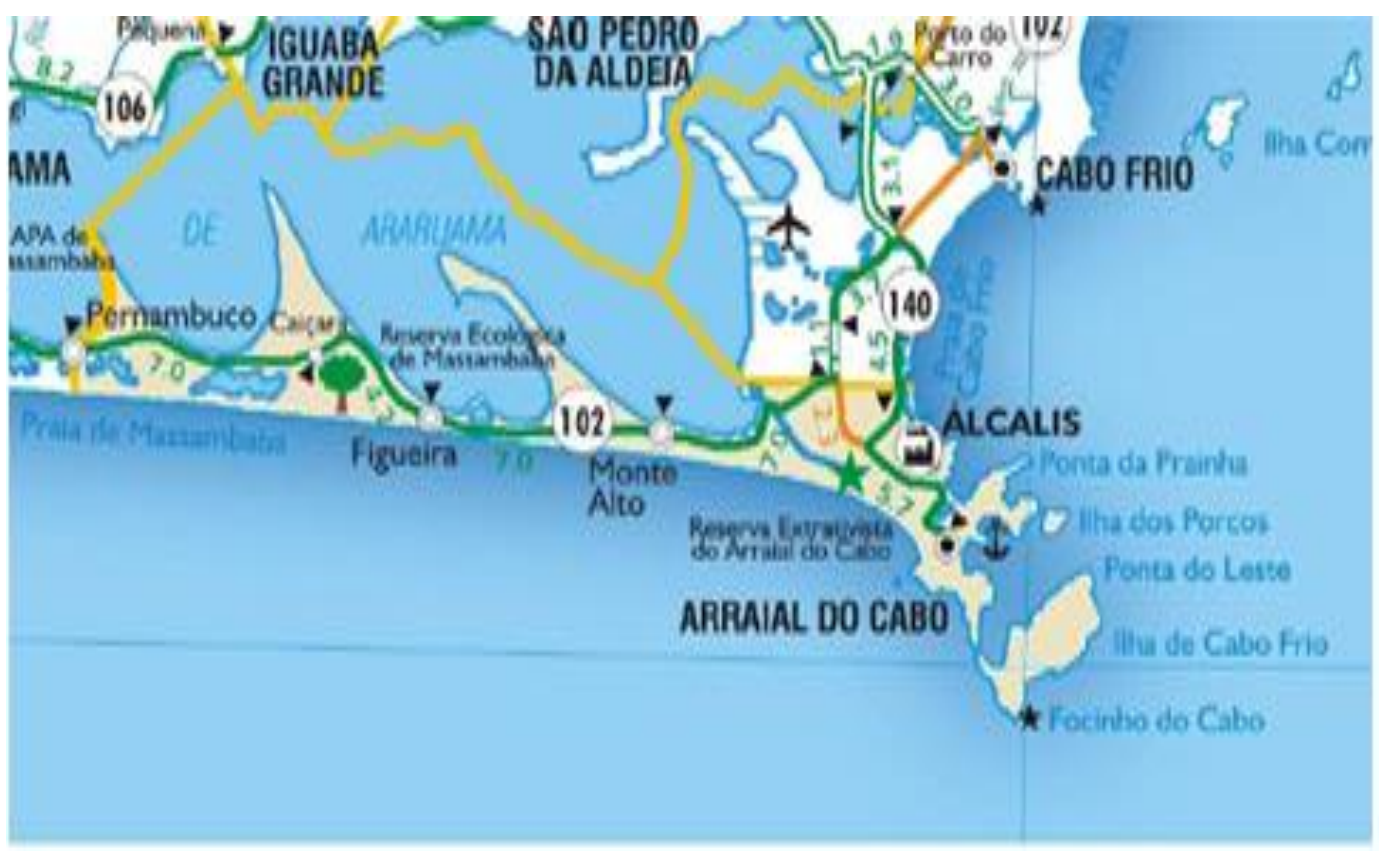

IBGE/CIDE, 2002

Segundo trabalho desenvolvido pela Fundação Estadual de Engenharia do Ambiente - FEEMA, intitulado "Perfil Ambiental do Município de Arraial do Cabo" (1988), o relevo do município apresenta duas unidades topográficas diferentes: uma pequena parte formada por morros com declividade e outra bem mais representativa, de relevo plano, constituída por restingas, esta última, que corresponde a quase $90 \%$ do território, está comprimida entre a Lagoa de Araruama, ao norte, e o Oceano Atlântico ao sul e ao leste.

Em termos geológicos é uma área de planícies marinhas, resultante da acumulação de sedimentos arenosos da Era Quaternária comportando praias, cordões arenosos, dunas e canais de maré, sendo uma região de grande importância ecológica, arqueológica e de beleza natural, além de se constituir em área de proteção natural contra a ação erosiva do mar.

O clima do município de Arraial do Cabo, segundo Barbieri (1984), é semiárido apresentando duas estações, o inverno que vai de julho a setembro e o verão de outubro a março. Na primeira, há a predominância dos ventos sul e sudeste com períodos mais frios, já na segunda há o domínio dos ventos leste e 
nordeste. A precipitação é de $750 \mathrm{~mm}$ ao ano, sendo que de outubro a janeiro o índice de pluviosidade é mais elevado do que o restante do ano.

Para Tenório et. al. (2010), a vegetação do município é distribuída em cinco tipos, a saber: manguezal, brejo, morros, lagoas e restinga localizada entre a Lagoa de Araruama e o mar, onde é possível encontrar raras orquídeas, bromélias, frutas silvestres e plantas medicinais, além de sítios arqueológicos de extrema valia para o estudo da história da região.

As características geomorfológicas, topográficas, metereológicas e hidrológicas peculiares da região de Arraial do Cabo fazem com que seja frequente a ocorrência do Fenômeno da Ressurgência. Este fenômeno desempenha forte influência na região, sendo determinante nas mudanças da temperatura e da umidade do ar.

De acordo a FEEMA (1988), a ocupação do município desencadeou-se em três fases. A primeira determinada pelas atividades pesqueiras e salineiras, a segunda etapa ocorreu nos princípios dos anos 1940 e deveu-se a implantação da Companhia Nacional de Álcalis, indústria criada na Era Vargas com a meta de produzir e comercializar barrilha para atender as necessidades das indústrias nacionais em franca ascensão devido à implantação de um novo modelo de desenvolvimento e a terceira fase está intimamente ligada a atividade turística que se desenvolveu nos princípios dos anos 1960 e que se acelerou nos anos 1980.

Com os objetivos de preservar o município, em particular as áreas remanescentes de restinga, lagoas costeiras e brejos, que abrigam espécies endêmicas e diversos sítios arqueológicos, o governo estadual criou em 15 de dezembro de 1986, por meio do Decreto 9.529, a Área de Proteção Ambiental na Lagoa de Araruama e Praia de Massambaba - APA de Massambaba, que compreende além do município de Arraial do Cabo, Araruama e Saquarema.

Esta unidade foi considerada insuficiente para controlar o crescimento desordenado e a degradação ambiental do município, assim o poder local, por meio da Lei Orgânica, em 1990 criou as seguintes unidades de Conservação Ambiental no município:

I) Parque Municipal da Praia do Forno;

II) Reserva Ecológica da Ilha do Farol;

III) Reserva Biológica das Orquídeas;

IV) Reserva Biológica da Lagoa Salgada; 
V) Reserva Biológica Brejo Jardim;

VI) Reserva Biológica Brejo Espinho;

VII) Parque Municipal da Praia do Pontal;

VIII) Parque Municipal da Fábrica;

IX) Parque Natural do Combo Grande.

A Lei Orgânica também criou no Município de Arraial do Cabo as seguintes Áreas de Preservação Permanente:

I - os manguezais e as restingas;

II - as nascentes e as faixas marginais de proteção de águas superficiais;

III - a cobertura vegetal que contribua para a estabilidade das encostas sujeitas à erosão e deslizamentos ou para fixação de dunas;

IV - as áreas que abriguem exemplares raros, endêmicos, vulneráveis, ameaçados de extinção ou insuficientemente conhecidos da flora e da fauna, os bancos de genes, bem como aqueles que sirvam como local de pouso, abrigo ou reprodução de espécies;

V - as áreas de interesse arqueológico, histórico, científico paisagístico e cultural;

VI - os pesqueiros, os vigias e os pontos de pesca;

VII - A Ilha de Cabo Frio, a Ilha do Francês, a Ilha dos Porcos, a Ilha do Pontal e o Boqueirão.

A Lei Orgânica criou ainda as Áreas de Relevante Interesse Ecológico Paisagístico a seguir:

I - as coberturas vegetais nativas;

II - a zona costeira;

III - a Praia e o Morro do Forno;

IV - o Morro do Miranda;

V - a Mata do Morro da Cabloca;

VI - as Prainhas;

VII - a Enseada da Praia dos Anjos;

VIII - Morro do Vigia;

IX - a Enseada do Forno;

X - a Prainha;

XI - Fortaleza;

XII - Costeira do Pontal do Atalaia; 
XIII - Ponta da Massambaba;

XIV - Morro e Ruínas do Telégrafo;

XV - Brejo do Espinho e Brejo Seco;

XVI - Brejo Salgado e Brejo Jardim.

Em 03 de janeiro de 1997, o Presidente da República, no uso da atribuição que lhe confere o artigo 84, inciso IV, da Constituição, e tendo em vista o que dispõe o art. $9^{\circ}$, inciso VI, da Lei 6.938, de 31 de agosto de 1981, e o Decreto ${ }^{\circ}$ 98.897, de 30 de janeiro de 1990, criou a Reserva Extrativista Marinha do Arraial do Cabo, compreendendo um cinturão pesqueiro entre a praia de Massambaba, na localidade de Pernambuca e a praia do Pontal, na divisa com Cabo Frio, incluindo a faixa marinha de três milhas da costa de Arraial do Cabo.

Considerada uma área de interesse ecológico e social, a Reserva Extrativista teve como objeto garantir a exploração autossustentável e a conservação dos recursos naturais renováveis, tradicionalmente utilizados para pesca artesanal, por população extrativista do Município de Arraial do Cabo.

Em 18 de abril de 2011, o governo estadual criou por meio do Decreto $\mathrm{n}^{\mathrm{o}}$ 42.929, o Parque Estadual da Costa do Sol, com área total aproximada de 9.840,90 hectares, dividido em quatro setores, cada qual composto por uma ou mais áreas distintas, abrangendo além do município do Arraial do Cabo, Araruama, Armação de Búzios, Cabo Frio, Saquarema e São Pedro da Aldeia.

Segundo a Lei 1.512/2007, que instituiu a Política Urbana de Controle do Uso do Solo no Município e que tem como objetivos racionalizar e direcionar a estrutura e o processo de ocupação e expansão urbana na cidade e nas localidades isoladas de Arraial do Cabo, adequando-as às peculiaridades físico-urbanísticas, necessidades de preservação ambiental e de desenvolvimento das funções sociais, culturais, turísticas e econômicas, o município é dividido em 04 (quatro) distritos, a saber: Arraial do Cabo distrito Sede, Monte Alto, Figueira e Pernambuca.

De acordo com o Censo do IBGE de 2010, Arraial do Cabo tinha uma população de 27.715 habitantes, correspondente a 3,4\% do contingente da Região das Baixadas Litorâneas, com uma proporção de 96,7 homens para cada 100 mulheres. O IBGE tem uma estimativa populacional de 30.096 pessoas para o ano de 2018. A densidade demográfica era de 172,91 habitantes por $\mathrm{km}^{2}$ contra 160,4 habitantes por $\mathrm{km}^{2}$ de sua região. A taxa de urbanização corresponde a $100 \%$ da população. 
No que tange os domicílios, o levantamento do IBGE mostrou que o município possuía 19.446 domicílios, dos quais $45 \%$ eram de uso ocasional, demonstrando o forte perfil turístico local.

Entre as principais atividades econômicas do município destacamos a pesca, o comércio, o turismo, que emergiu com força, atraindo uma nova safra de empreendedores criando uma alternativa de geração de renda e trabalho e o setor público.

Conforme salientou Estudo Socioeconômico de Arraial do Cabo do TCE, de 2017, em 2010 o Índice de Desenvolvimento Humano Municipal - IDHM de Arraial do Cabo era de 0,733 , ocupando a $940^{a}$ posição entre os 5.565 municípios do Brasil e a $20^{\mathrm{a}}$ posição entre os municípios do Rio de Janeiro. Sua faixa de desenvolvimento humano foi considerada alta, sendo a dimensão cujo índice mais cresceu em termos absolutos foi educação, seguida por longevidade e por renda.

Arraial do Cabo foi distrito de Cabo Frio até 1985, quando se emancipou. Em 01 de janeiro de 1986 assumiu o governo municipal o prefeito Renato Vianna de Souza, do PMDB. Como era um município novo, a primeira missão do poder público foi estruturar instrumentos de organização político-administrativa para a atuação governamental, visando à implantação das políticas públicas dentro dos limites outorgados pelos princípios constitucionais.

De acordo com a Revista Municípios em Destaque, Ano VIII, $\mathrm{n}^{\mathbf{0}} 32$, de maio de 1988, o prefeito Renato Vianna de Souza era consciente da vocação turística e do grande potencial econômico para o município, entretanto ressaltou que o prefeito pretendia investir primeiro na estrutura do município.

Nós não poderíamos, em hipótese alguma, antes de estruturar a nossa cidade com saneamento básico, construção de hospital e uma série de outras obras de infraestrutura, desenvolver o Turismo. (Depoimento do Prefeito Renato Vianna para a Revista Município em Destaque, 1988, p, 16).

Ainda de acordo com a Revista Municípios em Destaque (1988), o prefeito Renato Vianna realizou a pavimentação e urbanização de parte do município e ampliou o canal e as estações de tratamento de esgoto da Praia dos Anjos e Prainha. Além dessas ações, desvinculou a limpeza urbana da Secretaria Municipal de Obras e criou a Secretaria de Serviço Público, que identificou a disposição final do "lixo" como um dos principais problemas para a gestão. 
Segundo a FEEMA (1988), a coleta de lixo no município era executada pela Prefeitura na frequência de 03 (três) vezes por semana, não apresentando problemas que se destacassem, mesmo no período de veraneio.

Já no que tange a disposição final dos resíduos sólidos urbanos, a FEEMA apontou para um grave problema, pois os resíduos eram encaminhados para o vazadouro situado na Restinga de Massambaba, em direção à localidade de Monte Alto, onde se processava a queima dos resíduos, trazendo prejuízos ao meio ambiente pela fumaça que afugentava os agentes polinizadores do orquidário natural da restinga, além disso, os resíduos ficavam amontoados na restinga favorecendo a proliferação de vetores.

Ainda segundo a FEEMA (1988), a Prefeitura pretendia implantar uma Usina de Reciclagem e Compostagem de "Lixo" com recursos financeiros a serem obtidos junto ao programa organizado pelo Banco Nacional de Desenvolvimento Econômico e Social - BNDES, mas não obteve sucesso.

Em 1989 foi eleito prefeito de Arraial do Cabo, Hermes Barcelos do PDT. Na sua gestão foi instituída a Lei Orgânica do município, em 05 de abril de 1990, que, entre outras diretrizes, estabeleceu que a execução da política urbana estivesse condicionada às funções sociais da cidade, compreendidas como direito de acesso de todo cidadão a moradia, transporte público, saneamento, energia elétrica, gás, abastecimento, iluminação pública, comunicação, educação, saúde, lazer e segurança, assim como a preservação do patrimônio ambiental e cultural.

Em relação ao saneamento definiu que o município, na forma da lei, desenvolveria mecanismos institucionais e financeiros com a finalidade de garantir a toda população o acesso a esses serviços, entendido como abastecimento de água, esgotamento sanitário, sistema de coleta e disposição de resíduos sólidos urbanos, industriais e hospitalares bem como drenagem de canais.

No que tange a limpeza urbana, o manejo dos resíduos e a disposição final estabeleceu que caberia a este ente federativo prover sobre a limpeza das vias e dos logradouros públicos, a remoção e o destino do lixo domiciliar e de outros resíduos de qualquer natureza, bem como que estava vedada a criação de aterros sanitários à margem das lagoas, manguezais e mananciais.

Objetivando implantar uma de Gestão de Resíduos Sólidos, em particular da coleta seletiva, no ano de 1990, foi implantada a Usina de Reciclagem de "Lixo" de Arraial do Cabo, com as finalidades de preservar a Restinga de Massambaba, 
local onde era despejado todo "lixo" do município, gerar renda e diminuir os custos da coleta. A área localiza-se ao lado da antiga estação climatológica, numa distância média de $5 \mathrm{~km}$, tomando como referência o centro de Arraial do Cabo.

Figura 11: Galpão da Usina de Reciclagem.

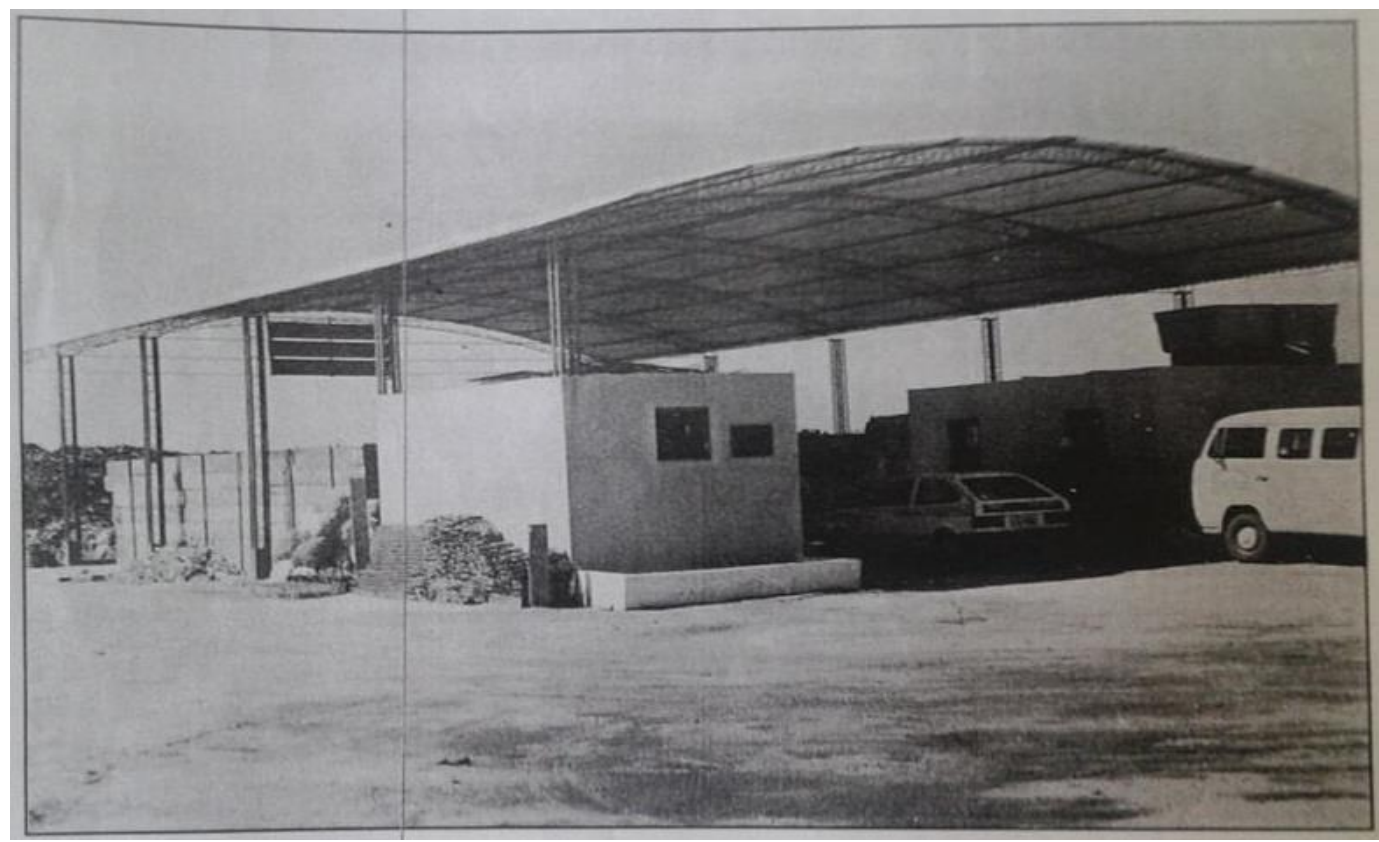

Fonte: Boletim Informativo da Prefeitura de Arraial do Cabo, Ano III, n 24/25, 1991, p. 12.

Com a morte de Hermes Barcelos, assumiu a gestão Francisco Luiz Sobrinho, popularmente conhecido como Chico Sobrinho, que deu continuidade ao projeto da Usina Reciclagem.

Segundo o Boletim Informativo da Prefeitura de Arraial do Cabo (1991), no ano de 1991 trabalhavam na Usina de Reciclagem 35 servidores municipais, distribuídos em dois turnos de seis horas diárias, que recebiam salário mínimo em carteira assinada adicionado $40 \%$ de insalubridade ${ }^{17}$, a condução de ida e volta para o local de trabalho, lanche diariamente e os Equipamentos de Proteção Individual (EPI) - macacão, luvas, botas e máscaras.

O sistema de funcionamento da Usina de Reciclagem era simples: o "lixo" trazido por quatro caminhões, sendo dois compactadores e dois baús, e pelos

\footnotetext{
17 A Lei Orgânica de 1990 determina em seu Art. 55 que a gratificação de insalubridade será de $20 \%$ a $40 \%$ - segundo o grau mínimo e máximo, sempre que o servidor estiver em atividades de locais insalubres, que por sua natureza, condições e método de trabalho, exponha-o a contato direto com agentes físicos, químicos ou biológicos nocivos que possam produzir doenças transitórias ou definitivas.
} 
tratores das praias era recebido no pátio de um galpão cimentado e coberto, no qual ocorria a operação de separação dos materiais orgânicos e inorgânicos.

Os materiais inorgânicos eram separados em depósito próprio para posteriormente serem vendidos, já os orgânicos eram encaminhados para o pátio livre para sofrer ação do oxigênio e da fermentação, sendo em seguida passados em uma peneira rotativa, acionada a um gerador próprio, que removia o material inerte restante transformando-o em adubo.

Figura 12: Peneira Rotativa.

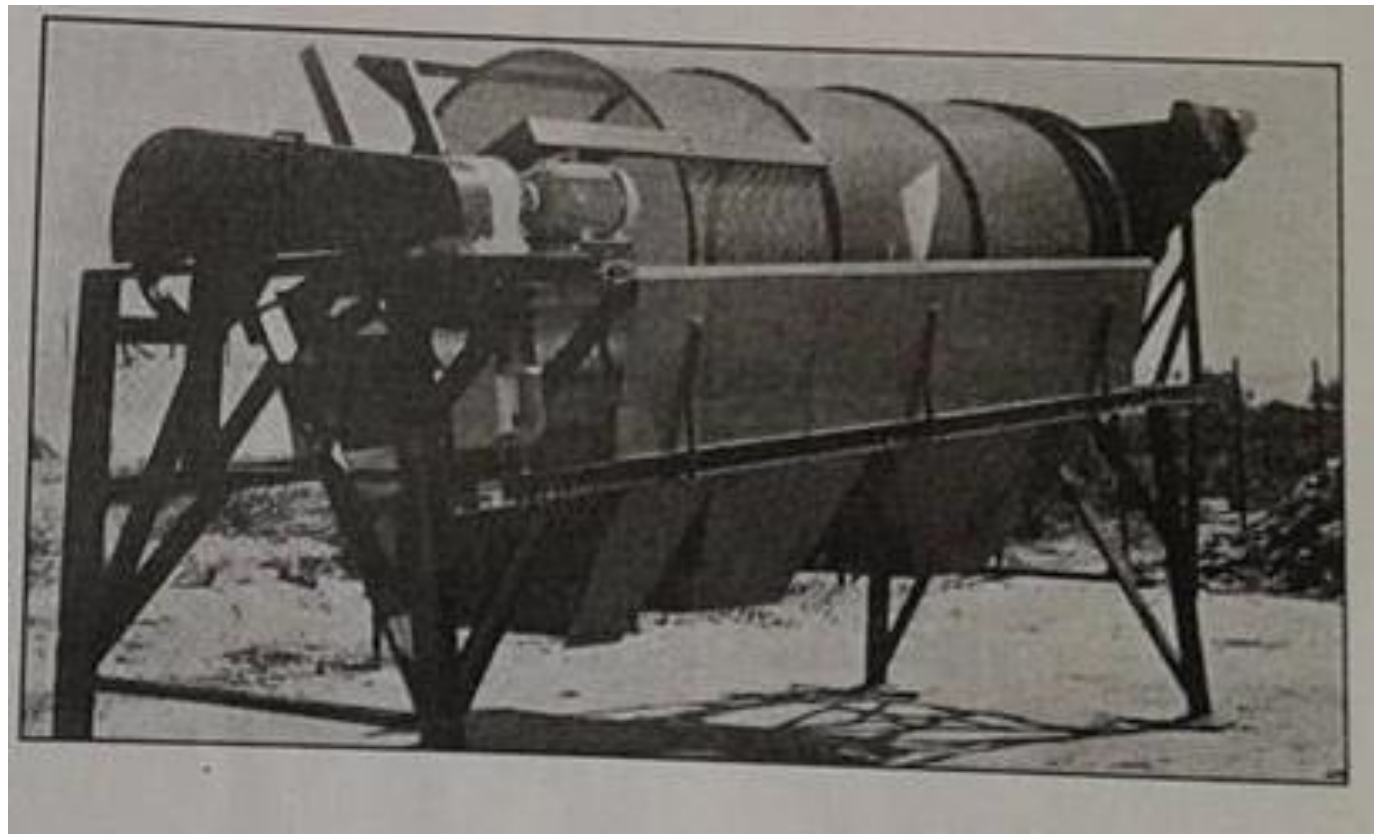

Fonte: Boletim Informativo da Prefeitura de Arraial do Cabo, Ano III, no 24/25, 1991, p. 12.

Em 1992, foi aprovado o Plano Diretor do Municipal. Nele, foi determinado entre outros aspectos, que a política de saneamento a ser instituída pelo Executivo teria como pressuposto básico melhorar as condições sanitárias do município mediante a implantação e operação de infraestrutura e de serviços públicos, priorizando a área urbana consolidada, as áreas de baixa renda, as áreas de expansão urbana a serem estabelecidas e as localidades urbanas de Figueira, Monte Alto e Pernambuca.

No referido Plano Diretor a política de saneamento deveria solucionar de forma integrada os problemas de esgotamento sanitário, macro e micro drenagem, de destinação final de resíduos sólidos e abastecimento de água.

No ano 1992, a revista Municípios em Destaque, produziu uma edição especial comemorando o $7^{\circ}$ de emancipação Arraial do Cabo. Numa linha de enaltecimento da competência administrativa do governo do município destacou 
as principais obras realizadas na gestão, dando ênfase à política de limpeza urbana e, mais precisamente, à Usina de Reciclagem.

Com o título "Um Outro Conceito de Lixo", a revista criticou a má gestão na limpeza urbana no Estado e enfatizou que em Arraial do Cabo ocorria um tratamento adequado na matéria. Argumentou que o sucesso era proveniente do fato de o governo municipal se antecipar ao problema e por tratar o "lixo" na Usina de Reciclagem, transformando-o em fonte de recursos, empregos, saúde e preservação ambiental.

Com raras exceções, o lixo de uma cidade é geralmente disposto em aterros sanitários ou lixões, o que, na verdade, só multiplica os problemas. Nos aterros sanitários, os órgãos públicos gastam fortunas para enterrar materiais que são recicláveis industrialmente, transportar o lixo para distâncias enormes, e desapropriar áreas cada vez mais valorizadas. Além disso, geralmente deterioram-se os serviços de operação e os aterros viram verdadeiros lixões. Além de ilegais, os lixões acarretam graves problemas sociais, de saúde e ambientais. Há proliferação de ratos, insetos e outros vetores, mau cheiro, contaminação dos cursos d'água e lençol freáticos que muitas vezes abastecem a cidade; (...). Em Arraial do Cabo, felizmente, as medidas necessárias começaram a ser tomadas antes que o problema se agravasse. Ao perceber a ameaça sofrida pela Restinga de Massambaba, onde todo o lixo era depositado, o saudoso prefeito Hermes Barcelos, idealizou e construiu a Usina de Reciclagem de lixo, inaugurada ainda em sua gestão. Seu sucessor, Francisco Luiz Sobrinho, não só garantiu o pleno funcionamento da Usina, como promove gincanas e distribui folhetos informativos, conscientizando a população da importância da coleta seletiva e orientando sobre os cuidados que se deve ter com o lixo. (...) Entre as inúmeras vantagens da coleta seletiva de lixo estão as de aspecto ecológico, ou seja, maior vida útil dos aterros sanitários, economia de energia, de recursos naturais e de matérias primas não renováveis. (...) Aspectos econômicos (redução de custos de coleta), sociais (evita acúmulos de favelas), políticos (a população participa na administração da cidade), e pedagógica (educação ambiental e conscientização da cidadania) também engrossam o rol de vantagens da coleta seletiva. (REVISTA MUNICÍPIOS EM DESTAQUE, 1992, p. 18, 19). 
Figura 13: Galpão de Triagem da Usina de Reciclagem em operação em 1992.

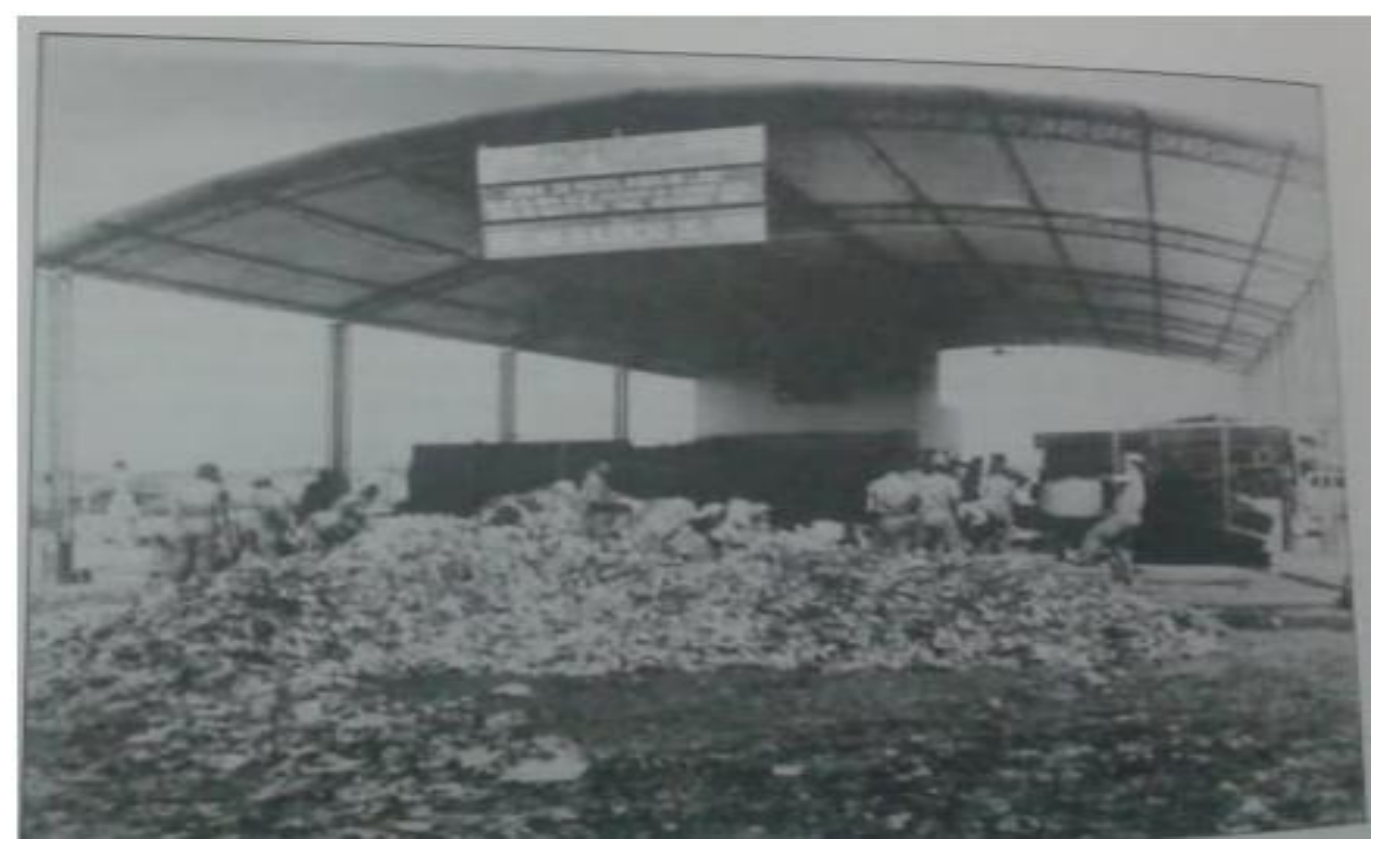

Fonte: Revista Município em Destaque, Ano XII, nº 46, maio de 1992, p. 18 e 20.

Figura 14: Funcionários da prefeitura trabalhando no Galpão de Triagem da Usina de Reciclagem fazendo a triagem dos resíduos.

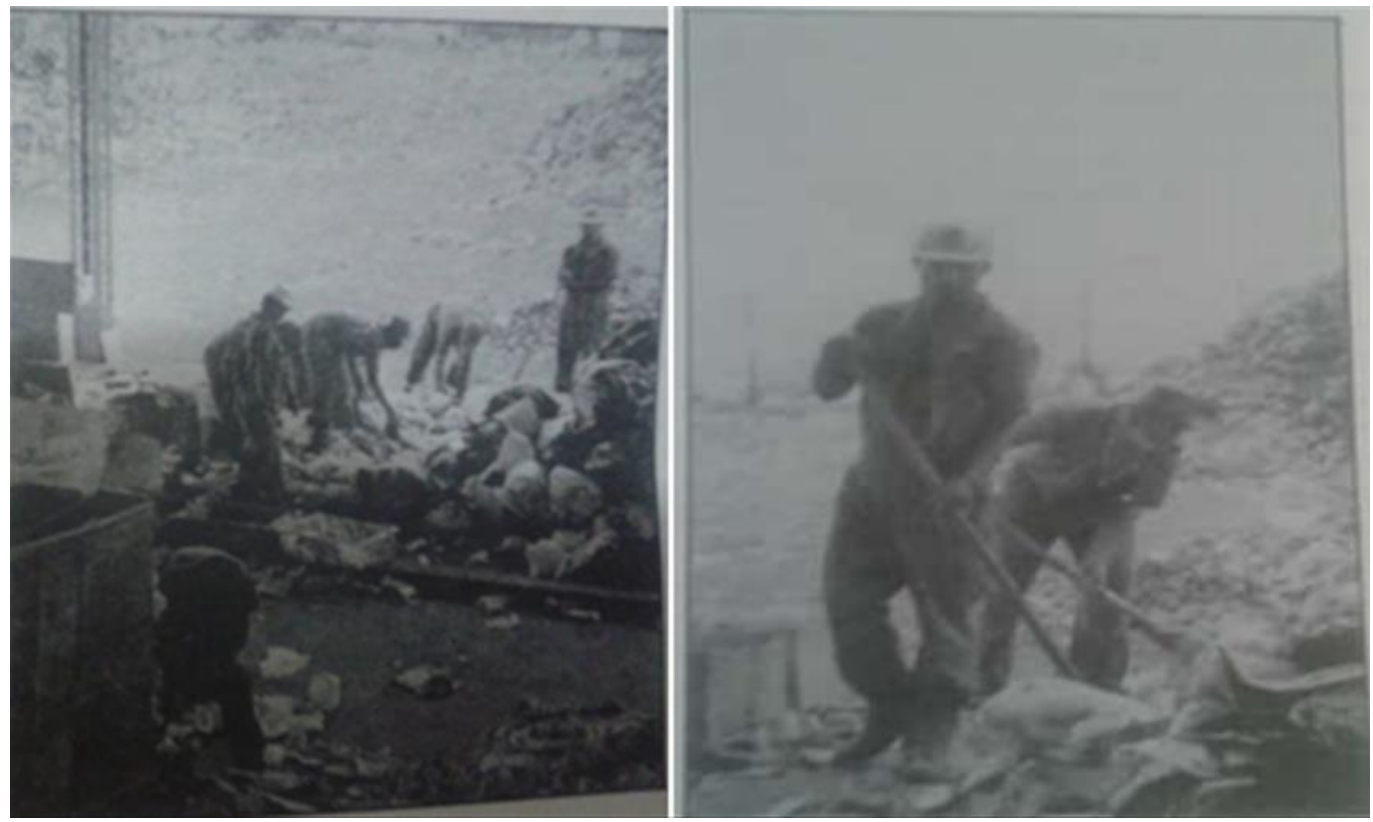

Fonte: Revista Município em Destaque, Ano XII, n 46, maio de 1992, p. 19.

Vale destacar que a gestão de resíduos nos anos de 1989 a 1992 foi considerada uma referência para a região e o Estado.

No ano de 1993 assumiu a prefeitura de Arraial do Cabo, David Dutra de Oliveira do PDT, médico e ex-vereador, que definiu como campos prioritários de atuação do poder público a saúde e o saneamento básico. 
Em relação ao saneamento a principal obra do governo David Dutra foi o fechamento do canal da Avenida da Liberdade, conhecido como valão reduzindo o mau cheiro e os riscos à saúde da população, o que foi considerado à época uma obra extremamente importante. Entretanto, no que se refere à gestão o gerenciamento de resíduos sólidos nada foi feito de relevante no município, em particular na Usina de Reciclagem, tanto do ponto de vista de estrutura e do redimensionamento das instalações como da readequação técnica de todo o processo operacional.

No ano de 1997, Renato Vianna assumiu pela segunda vez a prefeitura de Arraial do Cabo. Assim como no primeiro mandato, a gestão de resíduos sólidos não foi tratada como prioridade. No que tange ao gerenciamento dos resíduos, as ações eram centradas na limpeza urbana e no encaminhamento de todos os resíduos produzidos no município para o vazadouro de "lixo" e para a Usina de Reciclagem.

No período de 1997 até o final da gestão, não houve nenhuma modificação estrutural nas instalações da Usina de Reciclagem, seja na ampliação do galpão principal ou na aquisição de novos equipamentos.

Em 16 de abril de 1999 foi instalado o Procedimento Administrativo no Ministério Público Federal sob o $\mathrm{n}^{\circ}$ 08120.010014/99-81 para apurar irregularidades e danos ambientais causados pelo funcionamento do depósito de "lixo" a céu aberto na Usina de Reciclagem e de Compostagem, de responsabilidade do Município de Arraial do Cabo /RJ, sendo realizadas inúmeras diligências.

A Prefeitura Municipal de Arraial do Cabo informou aos 16 de julho de 1999 que as sobras de obras e entulhos seriam destinados ao "aterramento de ruas dos distritos de Monte Alto e Figueira", medidas estas que, sem o prévio planejamento e devido controle por parte do poder público pode ter contribuído para a expansão das referidas localidades sobre áreas de interesse ambiental, inclusive áreas de preservação permanente.

No ano de 2001 assumiu a prefeitura de Arraial do Cabo, Henrique Sérgio Melman do PDT, que impôs a Secretaria de Obras a responsabilidade pela limpeza urbana, o manejo e a disposição final dos resíduos.

Em relatório datado de fevereiro de 2001, o Secretário de Obras arguiu que: 
Ao longo dos dois governos subsequentes àqueles de Hermes Barcellos e Francisco Sobrinho, o que lá havia, além de não receber qualquer reforço de equipamento ou melhoria preconizada caiu em completo abandono. Assumindo o atual governo de imediato foi procedido uma inspeção detalhada que constatou que nenhum melhoramento foi acrescentado (...). A área em torno ampliou-se grandemente como um aterro sanitário, nome forçado para o que se fazia sem qualquer cuidado conforme preconizado. $\mathrm{O}$ local totalmente empestiado entregue a própria sorte, nele proliferando toda sorte de inconvenientes de ordem sanitária, a ponto de suscitar reclamação da vizinhança até de município vizinho. $\mathrm{O}$ único bem advinha para o grupo de necessitados que lá iam diariamente proceder a catação de reutilizáveis, como meio de obter pequena fonte de renda. Isso ocorria de forma totalmente insalubre não sendo difícil aquilatar os funestos resultados. Em resumo, lá só existiam as instalações prediais em má conservação. (AÇÃO CIVIL PÚBLICA nº 0000412-67.2007.8.19.0005, p. 5).

No dia 19 de fevereiro de 2002 foi instaurado o Inquérito Civil n 044/02, a partir do recebimento de procedimento administrativo deflagrado junto ao Ministério Público Federal, tendo por objeto a apuração das condições de funcionamento do lixão de Arraial do Cabo.

Indagado em 15 de julho de 2002 pelo Ministério Público sobre a gestão dos resíduos, o Secretário de Obras, afirmou "que o denominado Lixão de Arraial do Cabo na realidade não merecia tal epíteto, pois consistia em área de depósito e aterro das sobras do processo de seleção, reciclagem e incineração" (AÇÃO CIVIL PÚBLICA nº 0000412-67.2007.8.19.0005, p. 3).

Apesar do Secretário de Obras, em 2002, criticar as gestões anteriores pela falta de investimento e melhorias na Usina de Reciclagem, a administração do prefeito Henrique Melman também não fez mudanças significativas no sistema de gerenciamento de resíduos sólidos. Entretanto, cabe destacar que foi nesse governo que foi criado em 03 de setembro de 2002 a Fundação Municipal de Meio Ambiente, entidade pública, sem fins lucrativos, com personalidade jurídica própria, tendo como objetivo a execução da política ambiental do Município de Arraial do Cabo e como finalidades básicas:

- Implantar, fiscalizar e administrar as unidades de conservação e áreas protegidas do Município tais como, matas nativas, dunas, restingas, manguezais, encostas, recursos hídricos visando à proteção de mananciais, ecossistemas naturais, flora e fauna, recursos genéticos, e outros bens de interesse ambiental;

- Controlar os padrões de qualidade ambiental relativos à poluição atmosférica, hídrica, acústica e visual, e a contaminação dos solos, incluindo o monitoramento da balneabilidade das águas costeiras e de interiores; 
- Propor normas ambientais destinadas a disciplinar as atividades dos setores produtivos que operem no Município;

- Contribuir na definição das políticas de limpeza urbana em relação à coleta, reciclagem e disposição do lixo;

- Promover a conscientização política para a proteção do meio ambiente, criando instrumentos adequados para a educação ambiental como processo permanente, integrado e multidisciplinar em todos os níveis de ensino, incluindo a criação de espaços formais e informais para a construção de uma cidadania ambiental, especialmente em crianças e adolescentes;

- Operacionalizar a participação comunitária no planejamento, execução e vigilância das atividades que visem à proteção ambiental e ao desenvolvimento sustentável;

- Executar projetos específicos de defesa, preservação e recuperação do meio ambiente, incentivando a criação e absorção de tecnologias compatíveis com a sustentabilidade ambiental;

- Fiscalizar todas as formas de agressão ao meio ambiente, aplicando as penalidades previstas em Lei;

- Licenciar as atividades potencialmente poluidoras no âmbito do Município.

Ainda em 03 de setembro de 2002, foi criado no município o Conselho Municipal de Meio Ambiente, órgão consultivo e de assessoramento do Prefeito Municipal de Arraial do Cabo nos assuntos de meio ambiente, tendo como principais atribuições propor a política ambiental do município, as normas e os padrões de proteção, conservação e melhoria do ambiente do município, com vistas à elevação da qualidade de vida de seus habitantes, em observância as legislações Federal, Estadual e acordos internacionais vigentes e propor e participar da elaboração de campanhas educativas relativas aos problemas de saneamento básico, despoluição das águas, do ar e do solo, combate a vetores e proteção da fauna e flora.

No último ano da gestão de Henrique Melman, mais precisamente em março de 2004, o Ministério Público do Trabalho recebeu uma denúncia referente às condições laborais dos trabalhadores que prestavam serviços na Usina de Reciclagem de Lixo de Arraial do Cabo para a Empresa Cabista de 
Desenvolvimento Urbano e Turismo - ECATUR, que por sua vez, prestava serviços para o município de Arraial do Cabo.

$\mathrm{Na}$ referida denúncia os funcionários da empresa estariam trabalhando sem os direitos legalmente garantidos, pois não possuíam carteira assinada e sim um contrato de serviço de um salário mínimo, por meio do qual, segundo os próprios empregados, não havia a inclusão do adicional ao serviço insalubre.

Além desse aspecto, a denúncia ressaltava que os funcionários trabalhavam em precárias condições, sem o devido Equipamento de Proteção Individual - EPI e os materiais necessários ao bom andamento do serviço e a proteção individual e coletiva, o que acarretava alto risco à saúde considerando o contato direto com resíduos de toda cidade na Usina de Reciclagem de Lixo.

A denúncia destacava também que a empresa era responsável pela coleta de "lixo" e entulhos da cidade e que a fazia sem as condições mínimas de segurança. Destacava ainda, a queimada do "lixo" e o despejo aleatório e sem prévia descontaminação de "lixo" hospitalar.

Considerando que os fatos narrados configuravam, em tese, violação ao ordenamento jurídico, assim como lesão aos direitos difusos dos trabalhadores, o Ministério Público determinou a conversão da representação em procedimento preparatório de inquérito civil público, determinou a expedição de ofício ao Município de Arraial do Cabo para que informasse, no prazo de 10 dias úteis, os locais onde o "lixo" da cidade era depositado e que remetesse cópia do contrato de prestação de serviços firmado entre a Municipalidade e a empresa ECATUR e deu ciência dos fatos, através de ofício, ao Ministério Público Estadual para que providências necessárias quanto ao aspecto ambiental fossem tomadas.

No ano de 2005, Henrique Sérgio Melman foi reeleito prefeito do Município de Arraial do Cabo.

Em 25 de maio de 2005, o Ministério Público do Estado do Rio de Janeiro, por meio da Promotoria de Justiça de Tutela Coletiva, Núcleo Cabo Frio, resolveu regularizar a autuação do procedimento administrativo $\mathrm{n}^{\circ}$ 111/04 mediante lavratura de portaria de instauração de Inquérito Civil, com a seguinte ementa: Meio ambiente; Arraial do Cabo; Usina de Reciclagem de "Lixo"; observância da Política Estadual de Resíduos Sólidos; acondicionamento, coleta, transporte, tratamento e disposição final. 
Determinou em diligência juntar legislação e documentos anexos e oficiou a FEEMA, a Secretaria de Serviços Públicos de Arraial do Cabo e a ECATUR, para que apurassem as condições de atendimento às normas da Política Estadual de Resíduos Sólidos por parte do Município de Arraial do Cabo, solicitando informações acerca da operação da Usina de Reciclagem e da atividade de disposição final de resíduos sólidos no Município, mediante fornecimento dos seguintes dados em 30 dias:

- Licenciamento ambiental de operação da Usina de Reciclagem municipal;

- Cumprimento das medidas de controle ambiental na operação da Usina de Reciclagem;

- Capacidade de operação da Usina de Reciclagem para tratamento e disposição final dos resíduos sólidos do Município de Arraial do Cabo;

- Medidas efetivamente adotadas para a disposição de resíduos sólidos provenientes de serviços de saúde;

- Tratamento e disposição final do chorume acumulado a partir da disposição de resíduos sólidos;

- Resultado de auditorias ambientais porventura realizadas nos últimos 5 (cinco) anos;

- Identificação das medidas necessárias ao atendimento às normas de proteção ambiental vigentes;

- Informações complementares acerca dos sistemas de acondicionamento, coleta, transporte, tratamento e disposição final de resíduos sólidos no Município de Arraial do Cabo.

A FEEMA, em atenção ao ofício requisitório ministerial, realizou vistoria técnica no local em 05 de julho de 2005, oportunidade em que constatou a queima de "lixo" a céu aberto e a presença de catadores e de catadoras de materiais recicláveis.

Nessa operação, o titular da Secretaria Municipal de Serviços Públicos, responsável pela operação e manutenção do "lixão", recebeu a notificação no 650.752, e foi autuado com o Auto de Constatação $n^{\circ} 650.537$ por dar início à atividade sem a competente licença ambiental, tendo recebido o prazo de 20 dias para paralisar as atividades no lixão.

A FEEMA ressaltou que, no âmbito da atuação do Consórcio Intermunicipal para Gestão Ambiental das Bacias Hidrográficas da Região dos Lagos, a empresa 
Dois Arcos Transportes e Tratamento de Resíduos requereu através do processo E-07/202.940/04 Licença Prévia - LP para o Transporte Tratamento e Disposição de Resíduos Sólidos/Aterro Sanitário, para atender aos resíduos gerados nos municípios que compunham o referido consórcio, entre eles o de Arraial do Cabo.

Em março de 2006, o Ministério Público do Estado do Rio de Janeiro, por meio da Promotoria de Justiça de Tutela Coletiva, com vistas à instrução do Inquérito Civil $\mathrm{n}^{\circ}$ 111/04, que apurava as condições de atendimento às normas da Política Estadual de Resíduos Sólidos por parte do Município de Arraial do Cabo, encaminhou ofício à Empresa Cabista de Desenvolvimento Urbano e Turismo de Arraial do Cabo - ECATUR solicitando informações, no prazo de 30 dias, acerca da operação da Usina de Reciclagem Municipal, salientando que o não cumprimento no prazo poderia ensejar em responsabilização criminal.

O Ministério Público do Trabalho encaminhou ao Ministério Público do Estado do Rio de Janeiro, mais precisamente a Promotoria de Justiça de Tutela Coletiva de Cabo Frio a cópia de laudo pericial lavrado em 03 de maio de 2006 referente à inspeção realizada na Usina de Reciclagem de "Lixo" do Município de Arraial do Cabo, bem como no lixão a céu aberto, identificando a operação como sendo de responsabilidade da sociedade de economia mista ECATUR.

O laudo pericial informou que na inspeção foram recebidos pelo gerente, Gelzo Caralo, que afirmou haver 43 (quarenta e três) funcionários sem carteira de trabalho assinada, sendo pela empresa Emmanuel Teixeira Pontes Serviços (CNPJ 07.537.522/0001-76).

Indagado sobre as condições as quais estavam submetidos os trabalhadores, o próprio dono desta empresa, Sr. Emmanuel Teixeira Pontes, que estava no local, informou que não possuía meios de cumprir as obrigações trabalhistas, inclusive no que tange às carteiras de trabalho, visto que "tinha apenas contratos temporários com a Prefeitura".

De acordo com a inspeção o quadro era o seguinte:

Os empregados trabalham em dois turnos, o primeiro de $06 \mathrm{~h}$ às $12 \mathrm{~h}$ e o segundo de $12 \mathrm{~h}$ às $18 \mathrm{~h}$. Conforme verificado in loco, tanto a unidade de reciclagem quanto o lixão não oferecem mínimas condições de trabalho, expondo os trabalhadores à insalubridade do ambiente, além do contato com animais, principalmente urubus e cachorros, estando estes últimos claramente debilitados, com graves afecções de pele. Diversos insetos, destacando-se baratas, mosquitos, moscas e marimbondos completam a fauna local. $\mathrm{O}$ fornecimento de equipamentos de 
proteção individual é falho, não havendo qualquer fiscalização quanto a seu uso. Não são fornecidas máscaras, apesar do forte mau cheiro, e as luvas são inadequadas, desprovidas do Certificado de Aprovação, em desacordo com a NR 06. Cumpre salientar que a atividade de catação, em contato direto com o lixo e com animais, deve ser desestimulada, tendo em vista o seu alto grau de insalubridade, constituindo-se em um grave problema de saúde pública e, portanto, não restrito a questões atinentes à saúde do trabalhador. As patologias relacionadas a este trabalho são aquelas transmitidas pelos vetores que habitam ou procriam no lixo, destacando-se, além dos já mencionados, os ratos e porcos. Um risco adicional, por óbvio, é o contato com o lixo hospitalar e aquele proveniente de cemitérios. O empregado Cristiano de Oliveira Ribeiro, que trabalha exatamente com o lixo oriundo destes ambientes, nos informou sobre a inexistência de qualquer exame médico, clínico ou laboratorial, seja adimensional, periódico ou dimensional. Como ilustração, citaremos algumas dentre centenas de doenças geradas por este tipo de labor: leptospirose, peste bubônica e tifo murino, transmitidas pelos ratos; a toxoplasmose, transmitida por aves, suínos e gatos; a teníase, a cisticercose e a triquinelose, transmitida pelos suínos. E ainda as disenterias bacterianas e amebianas, as febre tifoide e paratifoide, a salmonelose, a cólera, a giardíase, a ascaridíase, a tricuríase, a ancilostomíase (amarelão), a AIDS, as hepatites, as dermatites, etc. Aos domingos, segundo informações colhidas, o lixão é invadido por catadores, incluindo crianças e idosos, já que não há qualquer controle por parte da ECATUR ou da Prefeitura de Arraial do Cabo. Trata-se de uma situação gravíssima, por colocar em risco grande número de pessoas (Ação Civil Pública $\mathrm{n}^{\circ}$ 0000412-67.2007.8.19.0005, p. 126, 127).

A inspeção concluiu que a instalação sanitária encontrava-se em precárias condições, sobretudo em se tratando de trabalho insalubre. Os banheiros estavam sujos, o lavatório sem material para a limpeza, enxugo e secagem das mãos e os chuveiros não funcionam a contento, deixando de proporcionar higiene adequada.

Não havia um refeitório propriamente dito, mas as refeições eram feitas em local com razoáveis condições de conforto e higiene. Existia apenas um bebedouro na sede, funcionado adequadamente, no entanto, não havia fornecimento de água nos locais de trabalho.

Os vestiários estavam em péssimas condições, com armários quebrados e sujos. Além de pequenos, mal ventilados, com portas danificadas e sem privacidade para os trabalhadores.

Diante dessas constatações, o Ministério do Trabalho determinou que fossem providenciados os registros de todos os empregados não vinculados a regime próprio de previdência, que fossem expedidos ofícios ao Ministério Público Estadual e à FEEMA, para que tomassem as providências que julgassem cabíveis. Determinou também que a Prefeitura Municipal de Arraial do Cabo apresentasse documento de licenciamento ambiental emitido pela FEEMA, que 
fosse solicitada às empresas ECATUR e Emmanuel Teixeira Pontes Serviços a imediata elaboração e posterior implantação do Programa de Controle Médico de Saúde Ocupacional e do Programa de Prevenção de Riscos Ambientais, e que a Prefeitura apresentasse o projeto com previsão para o início de funcionamento de um Aterro Sanitário ou outra solução técnica compatível com a saúde pública, a dignidade dos trabalhadores e a proteção ao meio ambiente.

Além desses pontos, determinou que fossem feitas limpezas diárias das instalações sanitárias, que nas frentes de trabalho fossem fornecidos água fresca e copos descartáveis, que o lavatório fosse provido de material para limpeza, enxugo ou secagem das mãos, proibindo-se o uso de toalhas coletivas, que fossem providenciados chuveiros, em perfeito estado, na proporção de 01(um) para cada 10 (dez) trabalhadores, que fossem providenciados vestiários com paredes construídas em alvenaria de tijolo comum ou de concreto e revestidas com material impermeável e lavável e que os armários fossem compartimentos duplos.

Em vistoria realizada no lixão de Arraial do Cabo, em 15 de maio de 2006, a FEEMA, com o objetivo de atender às solicitações do Ministério Público, produziu um relatório informando que a empresa responsável pelo recolhimento do "lixo" era Emmanuel Teixeira Pontes Serviços, que havia 42 (quarenta e dois) funcionários, sendo 35 (trinta e cinco) recicladores, 04 (quatro) vigias, 03 (três) encarregados e 20 (vinte) catadores eventuais e que eram recolhidos 35 toneladas/semana e 100 toneladas de resíduos no período de verão.

O relatório da vistoria informou que havia queima de "lixo" a céu aberto, que o "lixo" hospitalar era colocado em buracos e queimado e que o pátio da Usina onde funcionava a reciclagem estava limpo e com uma máquina em funcionamento.

Por fim, informou que Município de Arraial do Cabo não atendeu à Notificação 650.752 e sugeriu o encaminhamento do relatório de vistoria para a Central de Atendimento para que a empresa Emmanuel Teixeira Pontes Serviços fosse notificada e autuada por estar operando sem a competente Licença Ambiental.

Mediante a notificação e autuação procedida pela FEEMA, durante as vistorias realizadas pela equipe técnica do Ministério Público do Trabalho e os autos dos Inquéritos Civis $n^{\circ}$ 044/02 e $n^{\circ}$ 111/04 verificou-se situação de 
perpetuação de irregularidades nas atividades de tratamento e destinação de resíduos sólidos no Município de Arraial do Cabo, entre outros aspectos:

- A formação de vazadouro de resíduos sólidos adjacente à Usina Municipal de Reciclagem e Compostagem, caracterizando verdadeiramente a existência de um "lixão";

- A ausência de licenciamento ambiental e de observância às normas de controle ambiental de tratamento e destinação final de resíduos sólidos;

- A inexistência de uma Política Municipal de Gerenciamento de Resíduos Sólidos, contemplando um Programa Municipal de Coleta Seletiva, um Plano Integrado de Gestão de Resíduos da Construção Civil e um Programa de Gerenciamento de Resíduos Sólidos de Serviços de Saúde;

- A falta de um Cronograma de Medidas necessárias ao controle ambiental do vazadouro de resíduos sólidos em operação junto à Usina de Reciclagem e Compostagem do Município de Arraial do Cabo e;

- A deficiência na prestação dos serviços constatada pelo órgão estadual competente e a recusa no fornecimento das informações e dados requisitados.

Como desdobramento do não cumprimento das determinações, o Núcleo de Tutela Coletiva do Ministério Público Estadual em Cabo Frio, por meio da Promotoria de Justiça, em 02 de abril de 2007, instituiu uma Ação Civil Pública no 0000412-67.2007.8.19.0005, em defesa da ordem urbanística, da saúde pública e do meio ambiente, com requerimentos de antecipação dos efeitos da tutela final, nos termos do art. 273 do Código de Processo Civil e art. 12 da Lei no 7.347/85, em face do Município de Arraial do Cabo, da Empresa Cabista de Desenvolvimento Urbano, ECATUR e de Emmanuel Teixeira Pontes Serviços, determinando que:

- Elaborasse e implantasse o Programa Municipal de Gerenciamento de Resíduos Sólidos, incluindo no mínimo, a elaboração e a execução do Programa Municipal de Coleta Seletiva, do Plano Integrado de Gerenciamento de Resíduos da Construção Civil e do Plano de Gerenciamento de Resíduos de Serviços de Saúde em prazos a serem estabelecido por esse douto Juízo, sob pena de multa diária não inferior a $\mathrm{R} \$ 10.000,00$ (dez mil reais);

- Elaborasse um Cronograma de Medidas de controle e adequação ambiental para a operação da Usina de Reciclagem e Compostagem e do vazadouro de resíduos sólidos a ser apresentado à FEEMA, em prazo a ser estabelecido por esse 
douto Juízo para fins de prévia aprovação, sob pena de multa diária não inferior a $\mathrm{R} \$ 10.000,00$ (dez mil reais);

- O Município de Arraial do Cabo, a Empresa Cabista de Desenvolvimento Urbano - ECATUR e a Emmanuel Teixeira Pontes Serviços, solidariamente, recuperasse a qualidade ambiental da área destinada ao funcionamento da Usina de Reciclagem e Compostagem e do vazadouro de resíduos sólidos;

- Em caso de absoluta impossibilidade de renaturalização do ecossistema local, sejam os réus condenados solidariamente a executar medidas a serem indicadas pelo órgão estadual de competência ambiental à recuperação parcial da qualidade ambiental, mitigação dos efeitos ao ecossistema local e compensação pelos danos permanentes verificados;

- Condenasse os réus ao pagamento dos honorários de sucumbência a ser revertido ao Fundo Estadual do Ministério Público do Estado do Rio de Janeiro, nos termos da Lei $\mathrm{n}^{\circ} 2.819$, de 07 de novembro de 1997, e a Resolução GPGJ n 801, de 19 de março de 1998.

No dia 25 de abril de 2007, o juiz solicitou ouvir os réus em respeito ao princípio constitucional do contraditório para dar a sua decisão sobre o requerimento de tutela antecipada. Assim, produziu mandado de citação e intimação dos réus para responder à mencionada ação, no prazo de 60 (sessenta) dias, advertindo que, a não contestação, imputaria como verdadeiros, os fatos articulados pelo autor na petição inicial, bem como, intimá-los para que em 05 (cinco) dias, manifestassem sobre a antecipação dos efeitos da tutela.

Em 17 de maio de 2007, o município de Arraial do Cabo em resposta ao Ministério Público sobre a necessidade da implantação do programa municipal de coleta seletiva, dos planos integrados de gerenciamento de resíduos da construção civil e de resíduos dos serviços da saúde e do cronograma de medidas para adequação do sistema de tratamento e destinação de resíduos dos serviços de saúde arguiu:

Após consulta desta Procuradoria à Secretaria Municipal de Serviços e Operações Públicas, como se verifica da cópia do memorando anexo foi informado que quanto à necessidade da implantação do programa municipal de coleta seletiva, que já fora iniciado o seu planejamento com implantação prevista para o mês de julho/2007, todavia após problemas com a empresa contratada para realização dos serviços de coleta de lixo, seu início deverá ser um pouco retardado, não sendo, no momento, possível viabilizá-lo no prazo requerido pelo Ministério 
Público, necessitando o Município de maior prazo para sua conclusão. No tocante aos planos integrados de gerenciamento de resíduos da construção civil e de resíduos dos serviços da saúde, além do cronograma de medidas para adequação do sistema de tratamento e destinação de resíduos dos serviços de saúde, esclarece o Município que está em fase de implementação o vazadouro público municipal além de um novo equipamento para separação de lixo domiciliar, medidas que irão minimizar em muito os problemas relativos a estas questões. Esclarecemos ainda que em junho do corrente ano será iniciada a construção de um incinerador de lixo hospitalar, estando o Município aguardando somente a licença dos órgãos ambientais competentes, fato, que como é de conhecimento de V.Exa. levava-se algum tempo. Nota-se, portanto, que o Município já está, antes mesmo da propositura da presente ação, tomando todas as iniciativas necessárias para a implementação e conclusão dos programas necessários a seletiva de coleta do lixo e o plano de gerenciamento de resíduos da construção civil e hospitalar, além dos serviços da saúde em geral, sendo desnecessário o deferimento das liminares requeridas pelo Ministério Público. Por outro, caso não seja este o entendimento de V.Exa., o que se admite, respeitosamente, somente por hipótese, o deferimento das liminares na forma e prazos requeridos se tornariam totalmente inviáveis de cumprimento, em razão dos exíguos prazos, das normas legais que a municipalidade tem que observar e adotar e visando a concretização de seus atos e ações. Há de se observar ainda, além de disponibilidade financeira, prévia dotação orçamentária para a aplicação dos recursos públicos em todas as ações pretendidas pelo Ministério Público Estadual. Por todo o exposto, requer a municipalidade a não concessão das liminares requeridas, consoante às alegações e informações técnicas da presente. (AÇÃO CIVIL PÚBLICA n ${ }^{\circ} 0000412$ 67.2007.8.19.0005, p. 162, 163, 164).

Tendo em vista que o Município de Arraial do Cabo informou que o Programa Municipal de Coleta Seletiva, os Planos Integrados de Gerenciamento de Resíduos de Construção Civil e dos Serviços de Saúde e o Cronograma de medidas para adequação do sistema de tratamento e destinação resíduos estavam em fase de implantação, o Ministério Público, em 13 de março de 2008, solicitou à FEEMA a realização de vistoria nas dependências da Usina de Reciclagem e Compostagem do Município de Arraial do Cabo e no vazadouro de resíduos sólidos. Solicitou ainda um relatório em 60 (sessenta) dias, contendo a descrição das atividades e condições de operação do tratamento e destinação de resíduos sólidos, a existência de licenciamento ou processos de licenciamento ambiental, bem como identificação de medidas urgentes de controle ambiental das atividades realizadas.

No dia 01 de janeiro do ano de 2009 assumiu o governo do município de Arraial do Cabo, Wanderson Cardoso de Brito, Andinho do PMDB, diante de um quadro complexo no que tange a gestão e o gerenciamento de resíduos sólidos urbanos, inclusive com a Ação Civil Pública em andamento. 
Em 11 de fevereiro de 2009, o Instituto Estadual do Ambiente - INEA ${ }^{18}$, em resposta ao Ministério Público Estadual, vistoriou a área da Usina de Reciclagem e Compostagem e o lixão do Município de Arraial do Cabo.

$\mathrm{Na}$ vistoria constatou que a Usina de Reciclagem do Município de Arraial do Cabo funcionava com 49 (quarenta e nove) funcionários sendo 43 (quarenta e três) catadores e catadoras de materiais recicláveis, 04 (quatro) vigias e 02 (dois) administrativos. Constatou também que havia 01 (uma) esteira funcionando e que esta contribuía para a separação de trinta e cinco tipos de frações inorgânicas, entre elas papel, papelão, plástico, vidro, metal e madeira. Constatou ainda que o processo de compostagem encontrava-se desativado e que no lixão, os resíduos sólidos eram recebidos por 12 (doze) a 14 (quatorze) caminhões ao dia, que os dispunham sem nenhum tipo de tratamento como a cobertura dos resíduos com material inerte (argila) para impedir a propagação de vetores.

De acordo com a vistoria os resíduos sólidos dos serviços de saúde eram dispostos sem nenhum tipo de tratamento, em cavas a céu aberto, e posteriormente queimados, propiciando a contaminação do solo e das águas superficiais e subterrâneas, risco a saúde pública.

Como resultado da vistoria, o INEA notificou o município e solicitou no prazo de 30 (trinta) dias a apresentação das licenças ambientais para a atividade de operação da Usina de Reciclagem e de operação no lixão e informou que o não cumprimento dos termos da notificação acarretaria em penalidades previstas em lei.

Nos primeiros meses da gestão do prefeito Andinho, foi realizado pela prefeitura de Arraial do Cabo, por meio da Fundação Municipal de Meio Ambiente, Pesquisa, Ciência e Tecnologia, com apoio da Secretaria de Ambiente um diagnóstico preliminar sobre a estrutura do poder público municipal, das condições de organização e de funcionamento dos serviços de limpeza urbana,

\footnotetext{
${ }^{18}$ No dia 04 de outubro de 2007, por meio da Lei $\mathrm{n}^{\circ} 5.101$ foi criado o Instituto Estadual do Ambiente - INEA, entidade integrante da Administração Pública Estadual Indireta, submetida a regime autárquico especial e vinculada à Secretaria de Estado do Ambiente, com a função de executar as políticas estaduais do meio ambiente, de recursos hídricos e de recursos florestais adotadas pelos Poderes Executivo e Legislativo, com sede na Capital do Estado. O INEA foi instalado pelo Governo do Estado do Rio de Janeiro, em 12 de Janeiro de 2009, através do Decreto $\mathrm{n}^{\mathrm{o}}$ 41.628, a partir da fusão de três órgãos: FEEMA (Fundação Estadual de Engenharia de Meio Ambiente), SERLA (Superintendência Estadual de Rios e Lagoas) e IEF (Instituto Estadual de Florestas).
} 
manejo, destinação e disposição finais dos resíduos, dos passivos socioambientais e das reais condições de organização dos catadores e das catadoras de materiais recicláveis que atuavam na deteriorada Usina de Reciclagem e no lixão do município.

No diagnóstico constatou-se que na estrutura governamental do município de Arraial do Cabo o sistema de limpeza urbana e de manejo de resíduos sólidos era administrado pela Secretaria Municipal de Serviços Públicos e pela ECATUR, que contratavam empresas para a limpeza urbana, o manejo, a destinação e a disposição finais de resíduos sólidos ${ }^{19}$.

A execução das políticas ambientais cabia à Secretaria de Ambiente, ficando a cargo da Secretaria Saúde a supervisão e fiscalização do manejo dos resíduos de serviços de saúde, tanto os produzidos pelo próprio poder público como os da iniciativa privada.

O diagnóstico concluiu que não havia estudos gravimétricos para a identificação da origem, do volume e dos geradores de resíduos, nem dados confiáveis sobre os resíduos sólidos. Além destes pontos, inexistiam indicadores de desempenho a serem adotados nos serviços públicos de limpeza urbana, de manejo, destinação e de disposição finais dos resíduos.

Apesar da Lei Orgânica Municipal de 1990 determinar a criação de um Plano de Saneamento Básico e a Política Estadual de Resíduos Sólidos de 2003 estabelecer o instrumento do Planejamento Regional Integrado do Gerenciamento dos Resíduos Sólidos para disciplinar a geração, acondicionamento, armazenamento, coleta, transporte, tratamento, destinação e disposição finais dos resíduos sólidos no Estado do Rio de Janeiro, visando controle da poluição, da contaminação e a minimização de seus impactos ambientais, nenhum desses planos havia sido elaborado.

Diagnosticou-se que a coleta regular no município cobria 97,9\% dos domicílios e que os resíduos domésticos e comerciais sem uma separação prévia entre resíduos orgânicos e inorgânicos eram recolhidos segundo o modelo tradicional porta a porta, em dias e horários fixos, por meio de caminhões compactadores e de tratores.

\footnotetext{
${ }^{19}$ No município não havia a produção de resíduo industrial, radioativo e agrícola.
} 
Identificou-se também que os resíduos, em sua maioria, eram acondicionados em sacolas plásticas e, em alguns locais, na qual havia um grande quantitativo eram colocados em tambores e em caçambas para serem recolhidos e direcionados à Usina de Reciclagem e ao lixão e, posteriormente, após o processo de triagem, para o Aterro Sanitário Dois Arcos, em São Pedro D’Aldeia. Já os resíduos públicos, provenientes de poda, varrição, capina, roçada, feiras, mercado de peixe, praias, lagoas eram recolhidos pelas empresas contratadas pela Secretaria de Serviço Público e pela ECATUR e encaminhados à Usina de Reciclagem e ao lixão ${ }^{20}$.

E, por fim, foi verificado que no município de Arraial do Cabo não havia a disposição adequada dos pneumáticos e dos resíduos perigosos, que eram encaminhados para o lixão. É importante destacar que os pneus, quando descartados inadequadamente provocam assoreamento de rios e lagos, riscos de incêndio e a proliferação de mosquitos transmissores de doenças como a febre amarela, encefalite e dengue. Já resíduos perigosos - pilhas, baterias, lâmpadas fluorescentes, ao serem descartados inadequadamente liberam os componentes tóxicos no solo, nos cursos d'água e nos lençóis freáticos, afetando a flora e a fauna e próprio homem.

Os resíduos da construção civil, também chamados de entulhos, que representam um significativo percentual dos resíduos sólidos produzidos nas áreas urbanas também não recebiam uma destinação correta e eram encaminhados para a área do lixão de Arraial do Cabo. A sua disposição inadequada, sobretudo, numa região de restinga vinha impactando fortemente o ecossistema e a biodiversidade locais.

Também se concluiu que não havia coleta seletiva de forma institucionalizada promovida pelo poder público municipal.

O diagnóstico também constatou, por meio de um levantamento dos aspectos operacionais da Usina de Reciclagem, que à época de sua inauguração a referida usina possuía equipamentos que eram suficientes para a demanda do município, sendo inclusive considerada como referência para a região e o Estado.

\footnotetext{
${ }^{20}$ O município de Arraial do Cabo assinou no dia 03 de junho de 2009 um Protocolo de Intenções com o Governo do Estado do Rio de Janeiro e os municípios de Silva Jardim, Araruama e Saquarema, no qual esses farão uma Gestão Integrada e Associada do Aterro Sanitário, visando com base em critérios de engenharia e normas operacionais específicas, um confinamento seguro dos resíduos e, consequentemente, a proteção à saúde pública.
} 
Entretanto, com o passar dos anos, nenhum plano de redimensionamento das instalações da Usina de Reciclagem e de readequação técnica de todo o processo operacional foi realizado, o que gerou um quadro de incompatibilidade entre o que era gerado pelo município e a capacidade de processamento da usina, ficando então toneladas de resíduos acumuladas durante anos, depositadas a céu aberto numa área de restinga.

Constatou-se então que a falta de planejamento na coleta, compostagem e transformação dos resíduos sólidos para fins de reutilização ou reciclagem contribuíram para um pequeno reaproveitamento do material e, consequentemente, para a baixa geração de divisas e, por fim, ao indesejado aumento da quantidade de resíduos sólidos no ecossistema de restinga. Constatou ainda que a usina encontra-se antiquada, apresentando deficiências em todas as atividades realizadas, com equipamentos e maquinários insuficientes e sem manutenção, um sistema de triagem pouco dinâmico, um processamento de recicláveis de baixo aproveitamento, e a ausência de tratamento e destinação adequados para os resíduos da construção civil. Do ponto de vista técnicooperacional, verificou-se que todo o modelo de recolhimento, recepção, transporte, triagem e processamento do resíduo sólido praticado há alguns anos no município era ineficaz.

De acordo com o diagnóstico, toda área construída, composta pelo galpão de operações, na qual eram realizadas as atividades de triagem, enfardamento e armazenagem dos resíduos sólidos e por dois pequenos prédios anexos, cujas instalações foram utilizadas para abrigar o refeitório, dormitórios, vestiários e o departamento administrativo estavam em más condições, sendo necessária a sua readequação. As instalações eram totalmente inadequadas, pouco arejadas, sem locais de armazenamento adequado dos alimentos e sem condições de higiene. Os vestiários e dormitórios eram insuficientes para atender ao número total de trabalhadores, sendo um almoxarifado utilizado como extensão dos vestiários, por falta de espaço e de armários para guardar os pertences dos funcionários.

O setor administrativo também funcionava em condições precárias, em espaço bastante reduzido para comportar a mobília e os equipamentos necessários ao bom funcionamento deste setor e ainda apresentando problemas de iluminação e ventilação, o que dificultava a realização das atividades. 
Em termos de equipamentos, o diagnóstico constatou que na Usina de Reciclagem tinha um motor-gerador elétrico, uma peneira rotativa, uma esteira de rolagem para segregação dos resíduos sólidos recicláveis, uma prensa hidráulica e uma mesa de triagem. A prensa hidráulica funcionava em condições não muito adequadas. A esteira de rolagem utilizada para a segregação do lixo era pouco funcional e menos ainda ergonômica, pois esta apresentava uma profundidade maior que a ideal, o que inviabilizava o processo de triagem, podendo ocasionar lesões na coluna e outras doenças ocupacionais pela inadequação do equipamento às mediadas antropométricas.

Figura 15: Esteira e Prensa em más condições na Usina de Reciclagem de Arraial do Cabo.

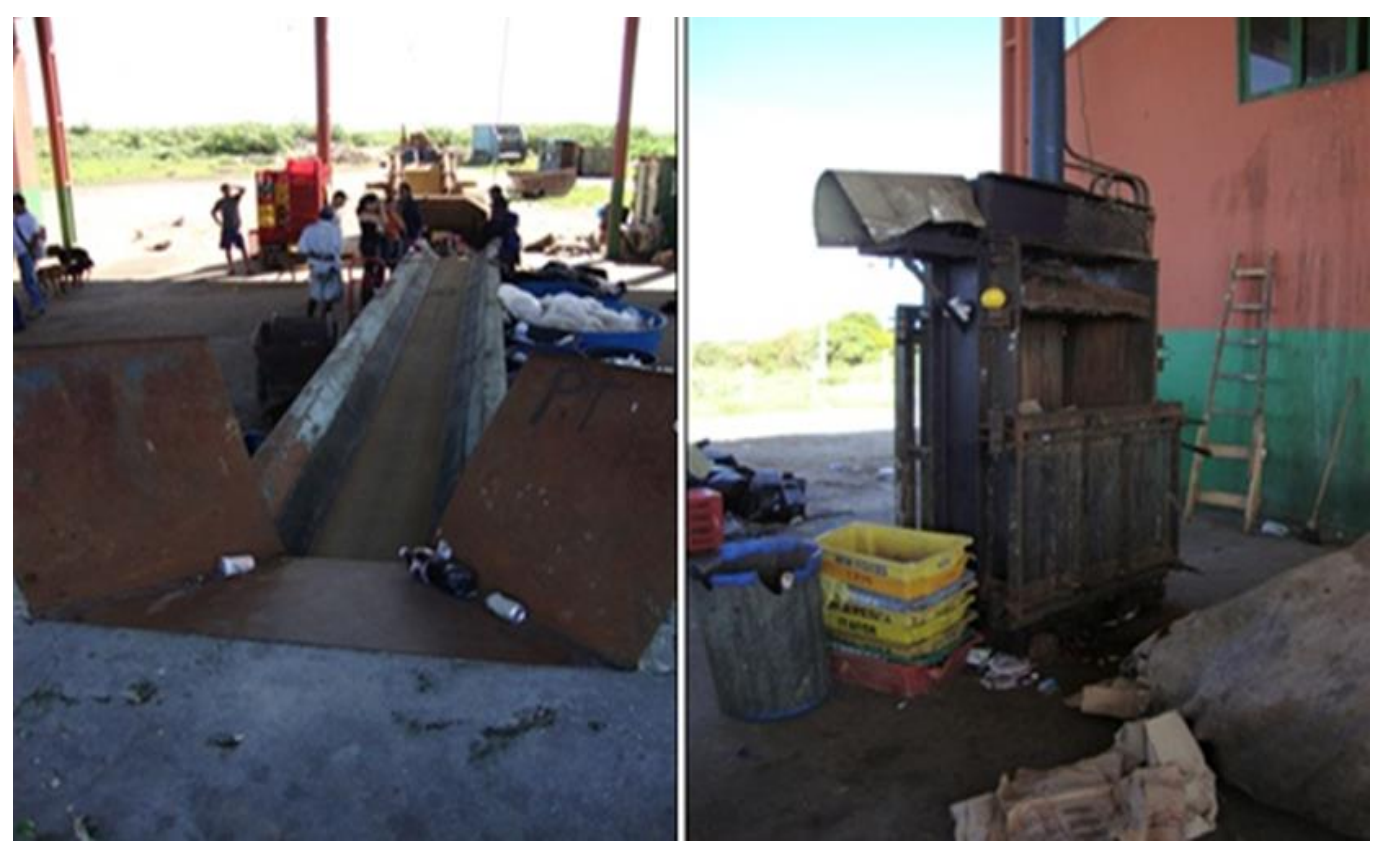

Fonte: Herick Simas, 2009.

O diagnóstico verificou que a lógica de processamento de resíduos sólidos operada consistia no despejo de resíduos dos caminhões direto no solo, com uma catação primária de recicláveis na pilha de resíduos. Em seguida ocorria uma triagem secundária na mesa fixa. Existia ainda um sistema de rampas, com uma área destinada à recepção dos caminhões para que estes descarreguem os resíduos na esteira de triagem. Todavia, este sistema, extremamente importante no sentido de dinamizar o processamento dos recicláveis, encontrava-se totalmente desativado, inclusive apresentando comprometimentos na estrutura de concreto, necessitando de uma reforma substancial para que voltasse a ser utilizado 
plenamente, eliminando a necessidade de dispor os resíduos em área exposta, além de evitar o emprego inadequado de trabalhadores na catação de lixo na pilha.

Figura 16: Rampa para recepção dos caminhões em precárias condições.

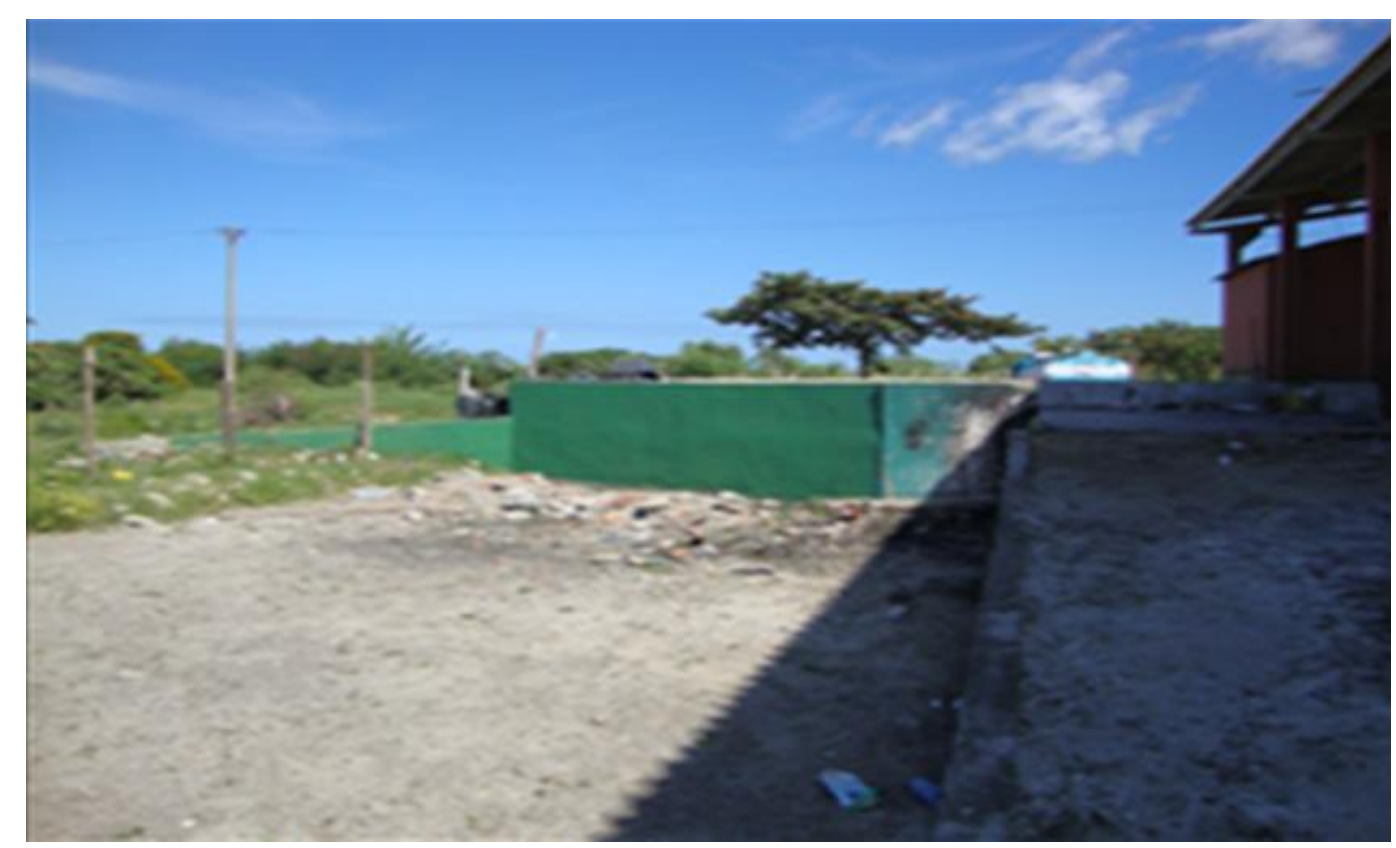

Fonte: Herick Simas, 2009.

A respeito da compostagem, que consiste em um processo natural de decomposição biológica de materiais orgânicos de origem animal e vegetal, pela ação microbiana, cabe ressaltar que, por ser um processo natural e biológico requeria um controle de fatores básicos, tais como temperatura, oxigenação e umidade.

Além disso, era preciso que se tivesse um sistema de higienização eficaz das instalações, a fim de se prevenir a exalação de odores resultantes da decomposição, a proliferação de vetores e a percolação do chorume pelo solo. No entanto, não foram observadas no local as estruturas destinadas para a decomposição aeróbica e maturação do lixo orgânico - Leiras de Maturação, assim como não existia um sistema de captação do chorume produzido por esta atividade.

De acordo com o presidente da Cooperativa de Coleta e Reciclagem da Costa do Sol e com as observações in loco, a pouca compostagem realizada era feita de forma bastante rudimentar, com a montagem das pilhas de lixo orgânico no pátio da usina, ficando o chorume produzido percolando pelo solo, longe de receber qualquer tipo de tratamento. 
Figura 17: Processo de Compostagem.

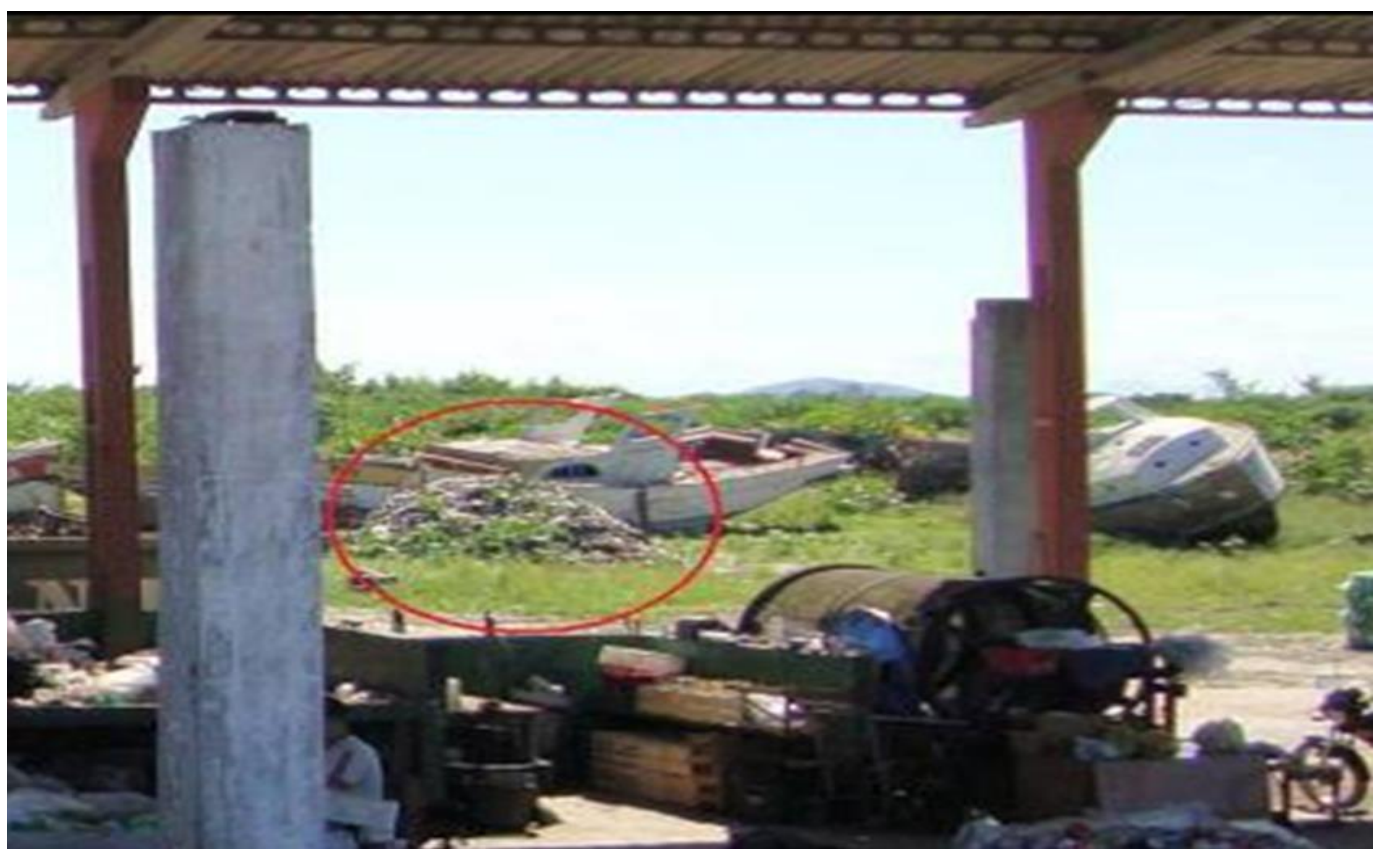

Fonte: Hercik Simas, 2009.

No diagnóstico foi encontrada uma quantidade bastante elevada de impactos ambientais e não conformidades com extensões realmente preocupantes.

Segundo a definição trazida pela Resolução do Conselho Nacional de Meio Ambiente - CONAMA n ${ }^{\circ}$ 001/86, os Impactos Ambientais são:

(...) alterações de ordem química e ou biológica do meio ambiente, causada por qualquer forma de matéria ou energia resultante das atividades humanas que, direta ou indiretamente, afetam: I - a saúde, a segurança e o bem-estar da população; II - as atividades sociais e econômicas; III - a biota; IV - as condições estéticas e sanitárias do meio ambiente; $\mathrm{V}$ - a qualidade dos recursos ambientais (RESOLUÇÃO CONAMA nº 001/1986).

A Usina Reciclagem de "Lixo" de Arraial do Cabo e o lixão municipal localizam-se dentro dos limites da Restinga de Massambaba, uma área de proteção ambiental rica em biodiversidade, com feições fitoecológicas bastante peculiares, com elevadas taxas de endemismo nestes ecossistemas. 
Figura 18: Foto aérea da Usina de Reciclagem.

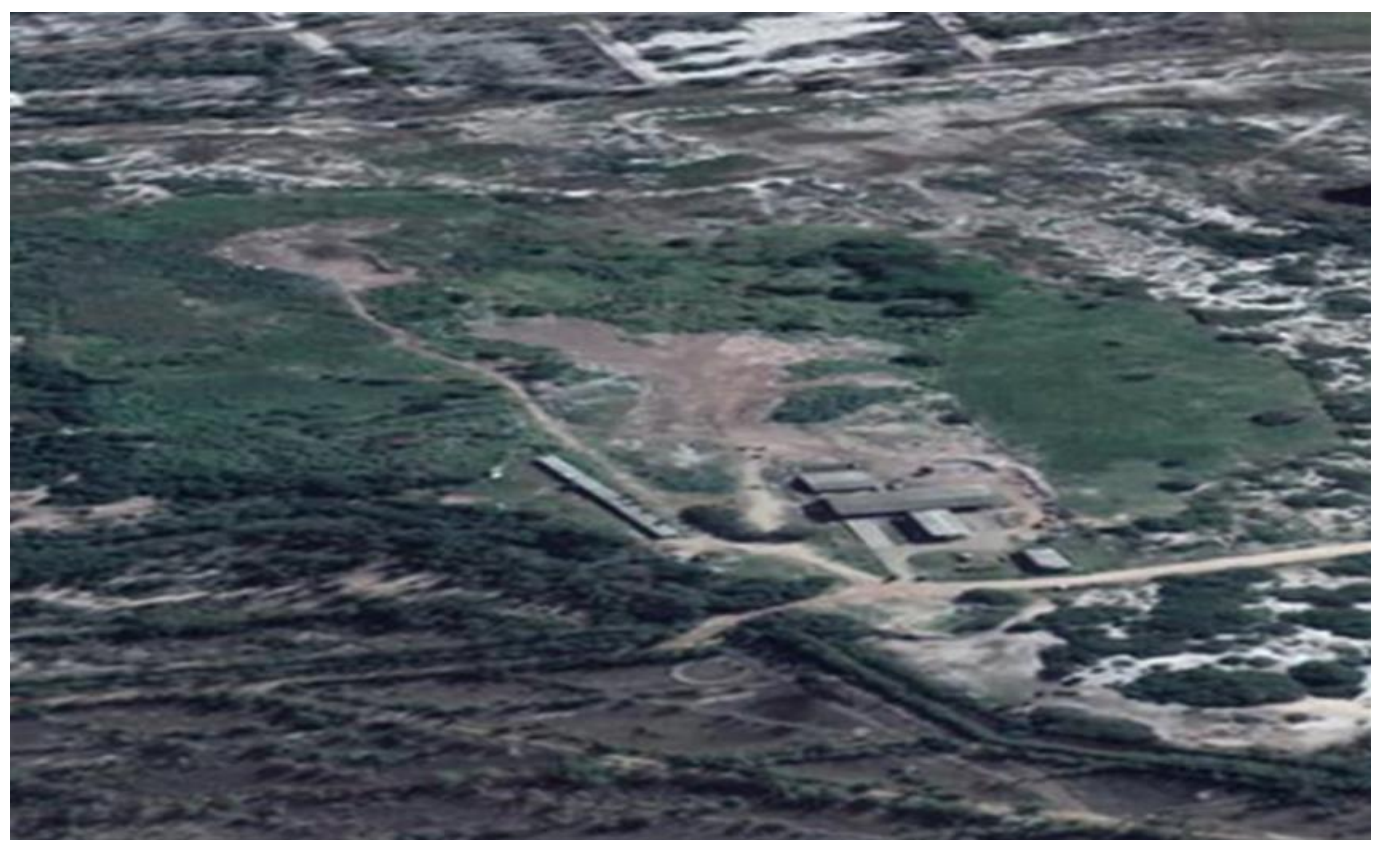

Fonte: Google Earth, novembro de 2018.

A disposição incorreta dos resíduos sólidos nesta localidade vinha provocando impactos sobre a fauna e a flora, bem como a contaminação dos corpos hídricos subterrâneos e a propagação de vetores que integram a cadeia de transmissão de muitas doenças.

Figura 19: Área adjacente à Usina de Reciclagem no município de Arraial do Cabo.

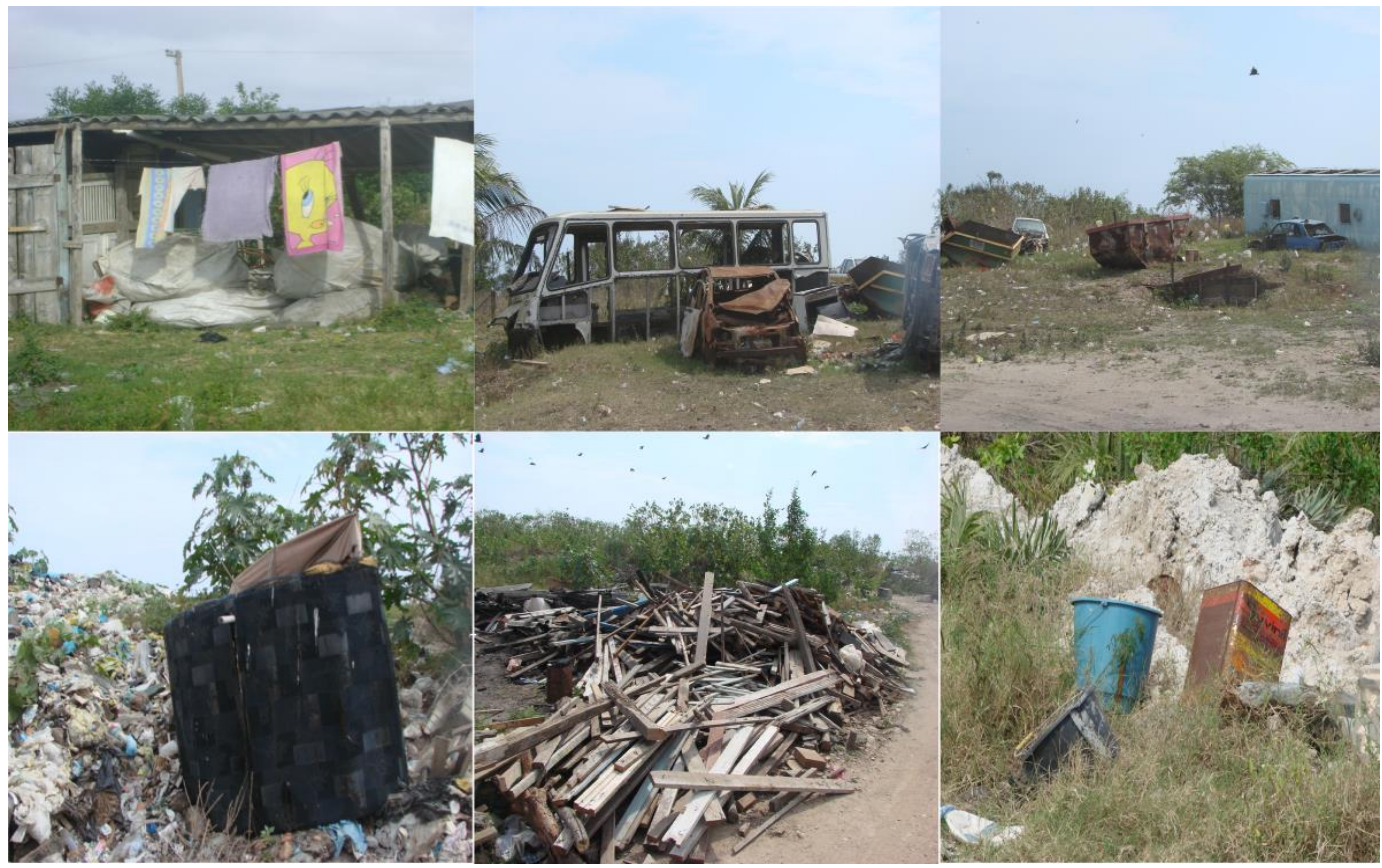

Fonte: Herick Simas, 2009. 
Figura 20: Lixão de Arraial do Cabo.

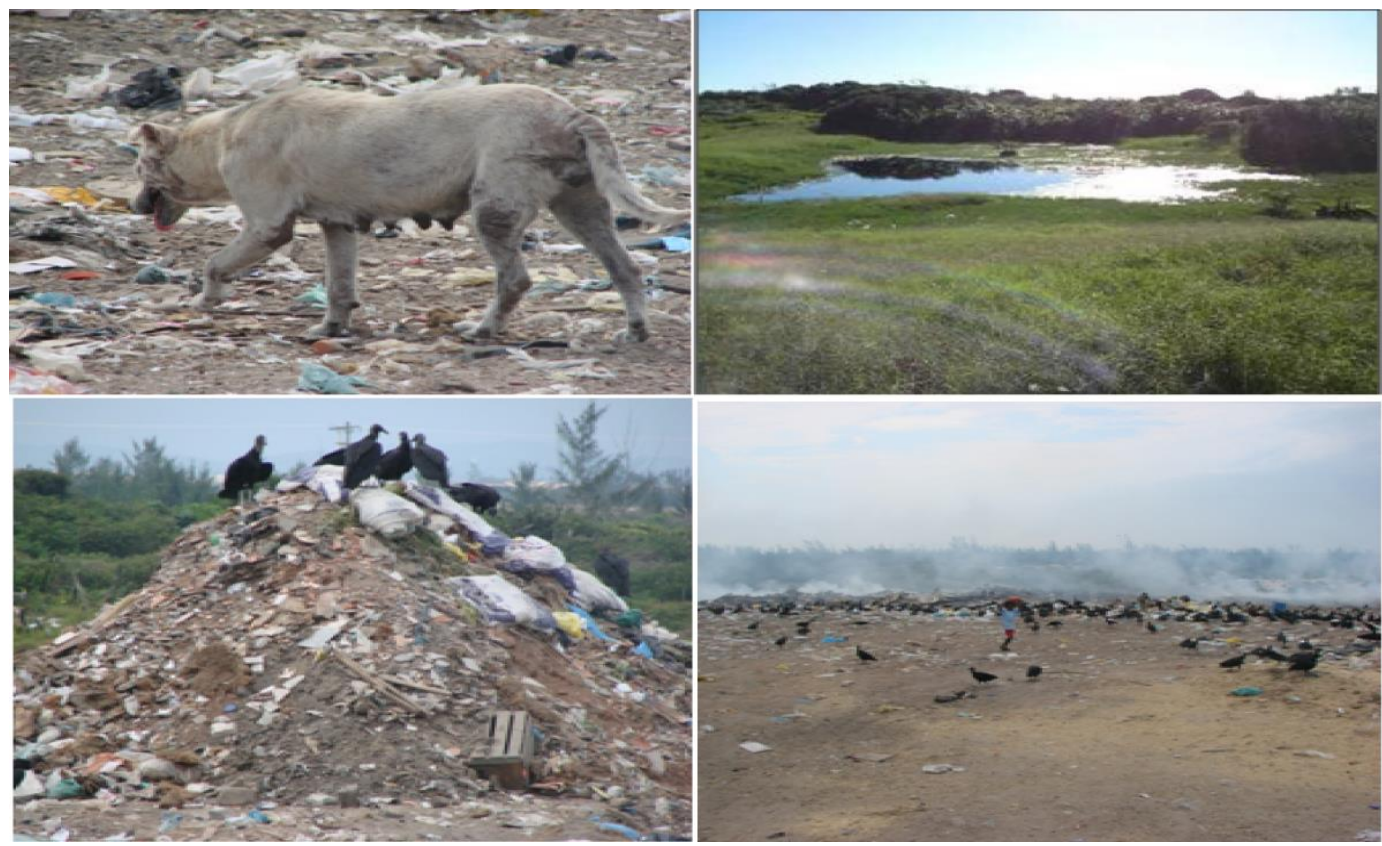

Fonte: Herick Simas, 2009.

Figura 21: Lixão de Arraial do Cabo.

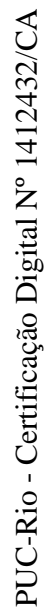

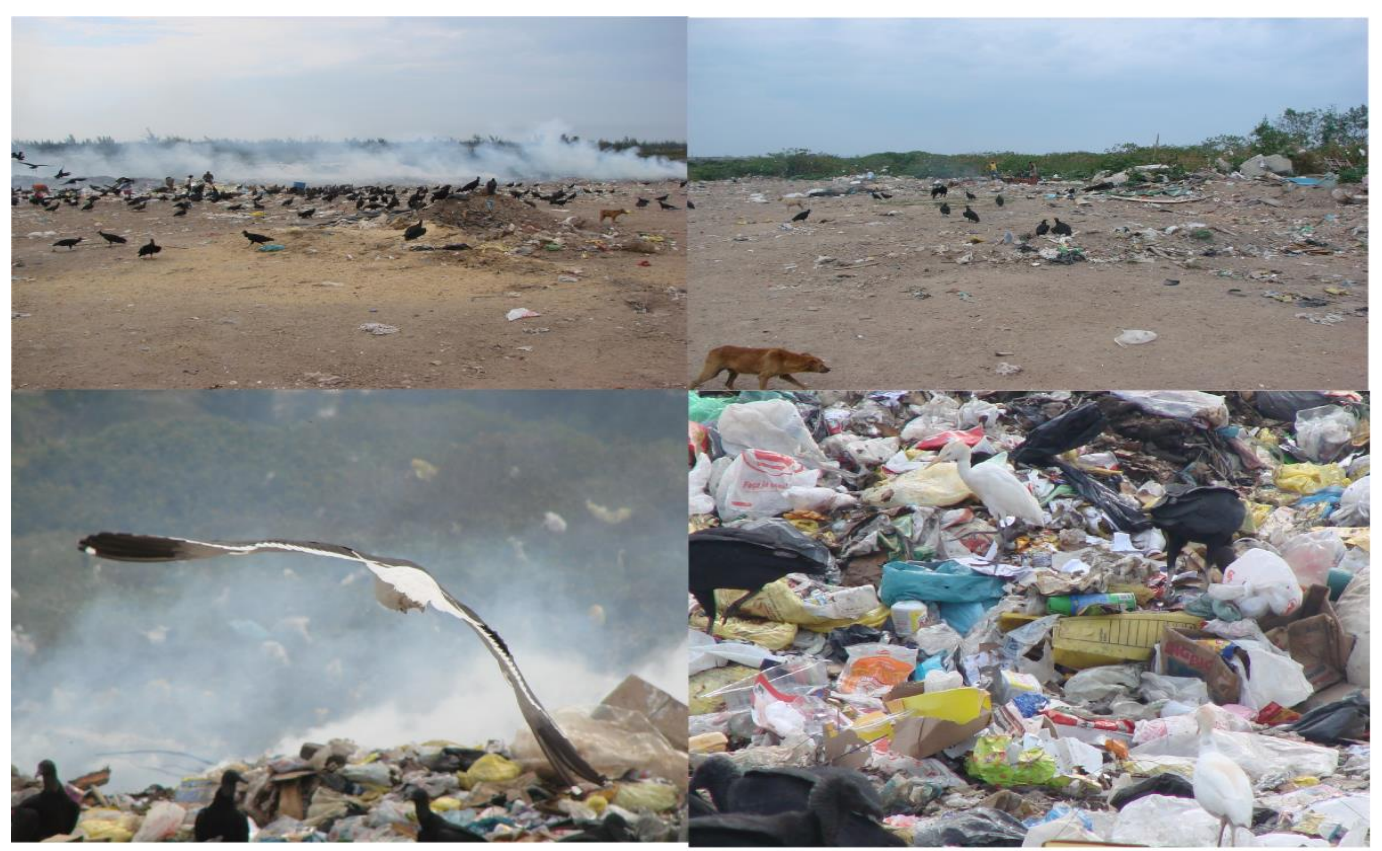

Fonte: Herick Simas, 2009. 
Figura 22: Lixão de Arraial do Cabo.

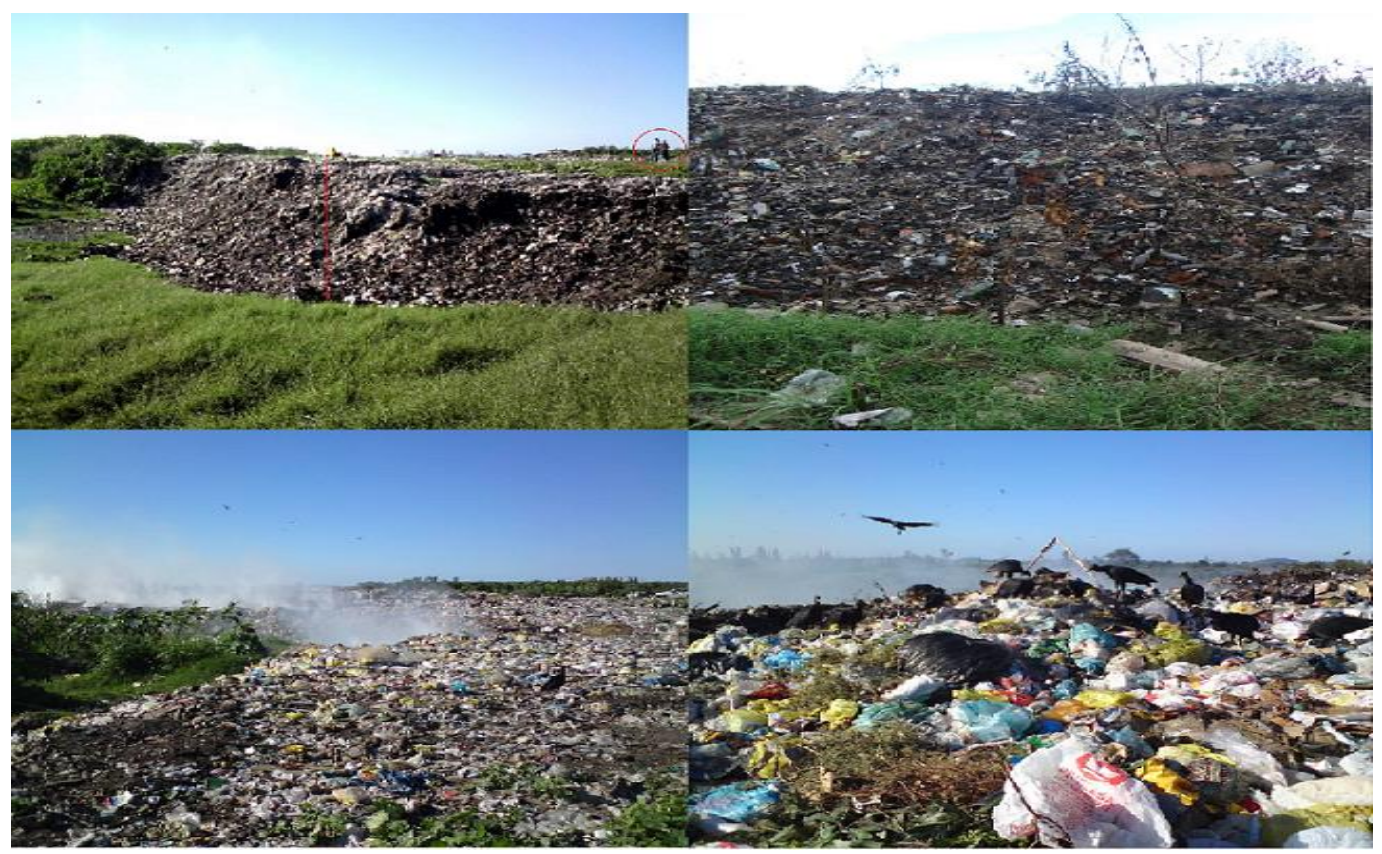

Fonte: Herick Simas, 2009.

No local havia a presença de moscas, ratos, urubus, e cães, muitos dos quais apresentando doenças cutâneas e parasitoses, não havendo nenhum meio efetivo de controle populacional destes organismos, nem tampouco medidas preventivas para o controle de zoonoses veiculadas por estes vetores, estando os catadores e as catadoras que trabalham no local sujeitos as patologias de origem animal.

A referida usina colecionava passivos ambientais das mais variadas categorias, sendo notificada por diversas vezes pela FEEMA e, posteriormente, pelo INEA, ficando a administração incumbida de mitigar as muitas não conformidades encontradas nas visitas técnicas realizadas pelos órgãos.

A ausência de licenciamento ambiental para as atividades de vazamento de resíduos sólidos adicionavam ao histórico da usina mais um grande passivo acumulado, inviabilizando investimentos e exigindo ações sobre todas as não conformidades quanto à gestão dos resíduos sólidos urbanos, entre outros aspectos, o adequado tratamento e remediação do solo, a destinação e o tratamento do chorume produzido ou ainda, quanto ao reflorestamento e recomposição florística da área.

Diante da gravidade do problema, fora proposta pelos setores mais ligados à área ambiental uma discussão para a construção da Política Municipal de Resíduos Sólidos, que deveria dispor sobre os princípios, os objetivos, os 
instrumentos e as metas, bem como sobre as diretrizes relativas à gestão dos resíduos sólidos ${ }^{21}$.

Mas tal iniciativa não seria de fácil alcance tendo em vista a ausência de recursos financeiros, a dificuldade em captá-los decorrente da inadimplência do município junto ao Governo Federal e, principalmente, pelo fato da administração pública municipal não ter a gestão dos resíduos como uma prioridade.

Considerando as variáveis ambiental, social, econômica, cultural, tecnológica e de saúde pública e a interdependência entre os diversos setores do governo, do setor privado e da sociedade para a gestão e o gerenciamento dos resíduos, esses setores propunham uma política pública integrada visando à universalização e a sustentabilidade nos serviços públicos de limpeza urbana, de manejo e destinação final dos resíduos sólidos, com a inclusão social dos catadores e das catadoras de materiais recicláveis, além da erradicação do lixão municipal, com remediação da área degradada.

Para tanto, concluíram que se fazia necessário, em consonância com a lei n ${ }^{\circ}$ 4.191/2003, que dispõe sobre a Política Estadual de Resíduos Sólidos do Rio de Janeiro, a elaboração de um planejamento municipal integrado do gerenciamento dos resíduos sólidos. Cabe salientar que este planejamento municipal integrado dos resíduos sólidos, com a promulgação da lei $\mathrm{n}^{\mathrm{o}}$ 12.305/10 corresponderia ao Plano Municipal de Resíduos Sólidos, instrumento fundamental da política, que estabeleceria um conjunto de ações legais, estruturais, operacionais, financeiras e de planejamento.

Com a execução desta política pública, Herick Simas, então Diretor do Departamento de Projetos da Fundação Municipal de Meio Ambiente, Pesquisa, Ciência e Tecnologia supunha que haveria melhorias na organização administrativa em razão das regras para a atuação do município, estabelecendo uma maior segurança jurídica e transparência na contratação pública e na prestação de serviços de limpeza urbana e de manejo dos resíduos.

Do ponto de vista legal, a Política Municipal de Resíduos Sólidos atenderia aos princípios da Legislação Estadual de Resíduos Sólidos Urbanos e, se bem

\footnotetext{
${ }^{21}$ Vale ressaltar que, no ano de 2009, ainda estava tramitando no Congresso Nacional o projeto de lei, que posteriormente iria instituir a Política Nacional de Resíduos Sólidos, por meio da lei $\mathrm{n}^{\mathrm{o}}$ 12.305/10.
} 
executada eliminaria os passivos socioambientais e, consequentemente, os problemas jurídicos ocasionados pela gestão inadequada dos resíduos sólidos.

$\mathrm{Na}$ esfera ambiental, argumentou Herick Simas, as melhorias se dariam em função de serem reduzidos os riscos de proliferação de vetores, de contaminação do solo, do ar e das águas subterrâneas e dos riscos à saúde e à segurança da população e dos catadores e catadoras de materiais recicláveis.

No âmbito social, afirmou que as melhorias ocorreriam em decorrência da inclusão participativa dos catadores e das catadoras de materiais recicláveis no processo de gestão dos resíduos e na perspectiva econômica, haveria a geração de renda e a redução dos gastos com a limpeza pública e com o envio apenas dos rejeitos ao aterro sanitário.

No dia 27 de abril 2009, a Ordem dos Advogados do Brasil, Seção do Estado do Rio de Janeiro, $20^{\circ}$ Subseção Cabo Frio apresentou Ofício ao Ministério Público Federal que o lixão de Arraial do Cabo continuava sendo explorado indevidamente pela municipalidade, implicando em violência inaceitável ao ambiente, merecendo pronto enfrentamento.

No dia 03 de setembro de 2009, a Fundação Nacional de Saúde - FUNASA, órgão executivo do Ministério da Saúde, por intermédio do Departamento de Engenharia de Saúde Pública - DENSP, no âmbito do Programa de Aceleração de Crescimento - PAC, na área de resíduos sólidos lançou um edital público, aprovando os critérios e os procedimentos para aplicação de recursos orçamentários e financeiros para a implantação, ampliação ou melhoria de unidades de triagem de resíduos sólidos para apoio às cooperativas e associações de catadores e catadoras de materiais recicláveis.

O referido edital partia dos preceitos da promoção e da proteção da saúde da população brasileira, e da necessidade de contribuir com as políticas de desenvolvimento regional e social destinadas à população de baixa renda que atuassem nas atividades de catação de materiais recicláveis em aglomerados urbanos.

Enquanto proponente, a Prefeitura formulou o pleito com base no diagnóstico realizado pela Fundação Municipal de Meio Ambiente, Pesquisa, Ciência e Tecnologia com apoio da Secretaria de Ambiente e encaminhou por intermédio do sistema de coleta de pleitos 2009 e 2010, disponível no sítio na internet: www.funasa.gov.br/SIGOB da FUNASA. 
No projeto enfatizou-se o fortalecimento dos dispositivos da lei $n^{\circ}$ 11.445/07, de 05 de janeiro de 2007, que estabeleceu as Diretrizes Nacionais para o Saneamento Básico e para a Política Federal de Saneamento Básico², a promoção de um sistema integrado de gerenciamento de resíduos sólidos prevendo desde a coleta até disposição final dos resíduos, com proposta de sustentabilidade do sistema de resíduos sólidos urbanos implantados e ações educativas e de mobilização social.

No dia 04 novembro de 2009, foi criada a Lei $\mathrm{n}^{\circ} 1.620$, que autorizou a participação do município do Arraial do Cabo na constituição do Consórcio Intermunicipal de Manejo de Resíduos Sólidos a ser construído pelos municípios de Araruama, Arraial do Cabo, Saquarema e Silva Jardim.

Em 03 dezembro do mesmo ano foi criada a taxa de licenciamento ambiental do município, que teve como fator gerador a atuação do órgão ambiental nas diversas fases e procedimentos do licenciamento ambiental de empreendimentos ou atividades consideradas poluidoras de pequeno e médio porte, bem como os capazes de causar impacto ambiental direto.

Após a análise do pleito pela FUNASA, a instituição informou no dia 16 de dezembro de 2009, que a proposta do município de Arraial do Cabo fora selecionada em conformidade com a Portaria $\mathrm{n}^{\mathbf{0}} 1.010$, de 03 de setembro de 2009, para firmar Termo de Compromisso com a FUNASA para investimentos de implantação, melhorias de sistema de reciclagem para apoio aos catadores de materiais recicláveis e que as obras civis e aquisição de equipamentos seriam acompanhadas pela Coordenação Regional da FUNASA no Estado do Rio de Janeiro. No dia 20 de janeiro de 2010 saiu o resultado no Diário Oficial da União, na seção 03, informando que o município de Arraial seria apoiado financeiramente, estabelecendo a celebração de convênio de repasse de recursos orçamentários e financeiros pela FUNASA.

Vale destacar que, ao concorrer com trabalhos de prefeituras, instituições e organismos de todo o país, o município foi o único do Estado do Rio de Janeiro a ser contemplado. Em 32 anos de emancipação político-administrativa do Arraial do Cabo, foi o primeiro projeto municipal a ser aprovado, via concurso público, condição até hoje singular em sua história.

${ }^{22}$ Vale lembrar que até este período a lei no $12.305 / 10$ não havia sido aprovada. 
Em 30 de março de 2010 foi criada a Lei $\mathrm{n}^{\circ}$ 1.653, instituindo a Política Municipal de Resíduos Sólidos de Arraial do Cabo, dispondo sobre as diretrizes gerais aplicáveis aos resíduos sólidos, lei, inclusive anterior à promulgação da lei 12.305/2010 - Política Nacional de Resíduos Sólidos.

Com a aprovação do projeto na FUNASA, o poder público municipal acreditava que já estaria apto a receber os recursos do convênio. Ledo engano, pois a partir de então começaram as exigências e as análises técnicas, ambientais, documentais e legais que acarretaram em um hiato de dois anos - entre 2010 e 2012 - para o início das obras. A não observância de qualquer um dos itens acarretaria a não liberação dos recursos.

Ainda no início do ano de 2010, a FUNASA submeteu o projeto do município a uma análise técnica de engenharia, com aspectos específicos a serem contemplados. No caso da análise técnica, os itens se referiam à documentação, ao projeto de engenharia e arquitetura, ao cronograma da obra, à planilha orçamentária e à aquisição de equipamentos.

No que tange à documentação, foi questionado se a população do município era de até 50 mil habitantes, se o município possuía o Plano Municipal de Saneamento elaborado nos moldes da lei $\mathrm{N}^{\mathrm{o}} 11.445 / 2007$ ou termo de compromisso para elaboração e implantação desse instrumento, e se existia compromisso por meio de cessão de uso de passar a operação do sistema para a cooperativa devidamente legalizada. Além desses pontos, foi questionado se o município não havia recebido recursos do governo federal nos últimos dois anos como apoio financeiro para a implantação, ampliação ou equipagem de unidades de triagem de materiais recicláveis, se existia lei municipal de coleta seletiva ou disposição do prefeito em institucionalizá-la, se existia licenciamento ambiental de acordo com legislação específica vigente, se existia projeto básico e exequível de engenharia e se existia gestão estruturada para prestação do serviço.

Questionou ainda se existia apoio formal aos catadores e as catadoras, por meio de órgão municipal, se os equipamentos e veículos automotores faziam parte do projeto, se os equipamentos estavam em conformidade com o galpão existente ou projetado, se existia documentação comprobatória de posse do terreno conforme Portaria $n^{\circ} 154 / 2009$ da própria FUNASA, se existiam aspectos relativos à implantação e gestão de programa de resíduos sólidos urbanos e se 
existiam programas que visassem à sustentabilidade dos sistemas implantados com a participação da comunidade.

Quanto ao projeto de engenharia e arquitetura, foi arguido se existiam plantas e desenhos em escala conveniente para análise, se havia todos os elementos suficientes para execução da obra, se existiam projetos de instalação prediais (elétricas, hidrossanitárias, ar condicionado e de prevenção e combate a incêndio), se existia identificação e assinatura de responsável técnico em todas as folhas do projeto, e se os memoriais descritivo e de cálculo estavam compatíveis com o projeto apresentado.

No que se referia ao cronograma físico-financeiro, a indagação foi no sentido de saber se ele estava de acordo com a obra proposta. No que tange à planilha orçamentária, o questionamento foi direcionado no sentido de saber se estava com a descrição dos itens, com suas respectivas unidades de medida e quantitativos e se apresentava custos iguais ou inferiores à média regulada pelos índices específicos do Sistema Nacional de Pesquisa de Custos e Índices da Construção Civil (SINAPI) e da Empresa de Obras Públicas do Estado do Rio de Janeiro (EMOP).

Em 10 de maio de 2010, o Ministério Público do Estado do Rio de Janeiro, por meio da $1^{\text {a }}$ Promotoria de Justiça de Tutela Coletiva do Núcleo de Cabo Frio, nos autos da ação civil pública, destacou que a questão do lixão de Arraial não era nova e que um dos inquéritos civis que instruía a ação datava de 2002, cerca de oito anos atrás. Destacou ainda que apesar do decurso desse lapso temporal, em que o Município exerceu sua atividade poluidora, não houve a criação de um plano de gerenciamento de resíduos e o "lixo" continuava a ser vazado numa área cercada por vegetação de restinga, o que tornava a atividade ainda mais perniciosa.

A Promotoria enfatizou que desde o ano de 2007 o Município noticiava a execução de medidas tendentes à criação do plano de gerenciamento de resíduos. No entanto, até o ano de 2010 o plano sequer fora esboçado.

O órgão ainda enfatizou que a única iniciativa do Município foi a assinatura de um consórcio entre os Municípios de Arraial do Cabo, Araruama, Saquarema e Silva Jardim para destinação final dos resíduos sólidos urbanos dos quatro Municípios em aterro sanitário no Município de Saquarema, todavia destacou que mesmo com essa medida positiva haveria ainda a necessidade de reparação do 
dano causado ao ambiente, além da contenção do chorume que continuava a contaminar a Lagoa de Araruama.

Nesse sentido, procedeu ao argumento de que na petição inicial foram requeridas na antecipação de tutela a apresentação pelo município de um Programa Municipal de Coleta Seletiva, do Plano Integrado de Gerenciamento de Resíduos da Construção Civil, do Plano de Gerenciamento de Resíduos de Serviços de Saúde - PGRSS do Hospital Geral Municipal de Arraial do Cabo, do Cronograma de Medidas necessárias à adequação do sistema de tratamento e destinação de resíduos dos serviços de saúde, mas as medidas requeridas não foram apreciadas pelo Poder Judiciário desde a data da propositura da ação em 2007.

Assim, foi destacado que na vistoria realizada em outubro de 2009, pelo próprio Ministério Público com o apoio do INEA, um conjunto de irregularidades, entre elas que os catadores e a catadoras trabalhavam com "lixo" contaminado quando a coleta seletiva deveria ser feita na fonte de produção do "lixo", as pilhas e baterias ficavam em contato com o solo, os pneus eram depositados a céu aberto, as sobras do "lixo" após a triagem feita pelos catadores (as) cooperados (as) eram lançadas a céu aberto e não eram cobertas com material inerte, o que atraia urubus e vetores de doenças, facilitava a combustão do "lixo" e a dispersão de odores.

Além desses aspectos foi apontado por eles, que havia a presença de catadores clandestinos, e que o "lixo" não era compactado e formava um talude íngreme, com grande produção de chorume, que não era destinado para bacias de contenção e, como o terreno era arenoso, facilitava a percolação e a contaminação do lençol freático e da Lagoa.

Afirmou que, diante das irregularidades constadas, foram recomendadas algumas medidas emergenciais, entre as quais o cercamento da área em que estava depositado o "lixo" para contenção da expansão do lixão, a vigilância permanente para evitar a ação dos catadores clandestinos e a cobertura do "lixo" existente com argila.

Assim, em razão dos fatos constatados na vistoria, a Promotoria adicionou aos requerimentos do Ministério Público dois requerimentos, a saber: que o Município fosse compelido a paralisar o vazamento de "lixo" no lixão e apresentasse alternativa de disposição final dos resíduos sólidos urbanos em aterro 
licenciado pelo INEA e que o Município fosse compelido a efetivar as medidas emergenciais recomendadas, devendo noticiar seu cumprimento.

Em 10 de agosto de 2010, o juiz Aylton Cardoso Vasconcelos, acreditando na verossimilhança das alegações formuladas e do risco de lesão irreparável ao meio ambiente, concedeu, em parte, a antecipação dos efeitos da tutela jurisdicional, sob pena de multa diária de $\mathrm{R} \$ 1.000,00$ (mil reais), intimando o Município de Arraial do Cabo para cumprimento da ordem, com urgência.

O município de Arraial do Cabo, no dia 21 de setembro de 2010, por seu procurador em resposta aos autos da Ação Civil Pública, que lhe moveu o Ministério Público do Estado do Rio de Janeiro, veio manifestar que desde o primeiro dia da gestão iniciada no ano de 2009 teve por objetivo sanar os problemas socioambientais decorrentes do precário tratamento dos resíduos sólidos urbanos no município acumulado a longos anos.

Para tanto, desenvolveu um conjunto de programas e projetos, entre os quais destacou a inserção do município no Programa Lixão Zero desenvolvido pela Secretaria Estadual do Ambiente, a instituição da Política Municipal de Resíduos Sólidos, por meio da Lei 1.653 de 30 de março de 2010, a participação na constituição do Consórcio Intermunicipal de Gestão de Resíduos Sólidos com os municípios de Saquarema, Araruama e Silva Jardim, o estabelecimento do Gerenciamento de Resíduos de Serviços da Saúde do Hospital Geral de Arraial do Cabo, com a contratação de empresa prestadora de serviços de recebimento final de resíduos hospitalares, com destino adequado na Empresa dos Arcos Transporte e Tratamento de Resíduos Sólidos LTDA, que operava no Aterro Sanitário licenciado pela FEEMA em toda Região dos Lagos (1J0 FE 13200), o pleito municipal de participação do Programa da Compra do Lixo Tratado.

Além dessas ações, enfatizou o processo de fiscalização e monitoramento da situação do Lixão, em particular quanto à ação de catadores clandestinos com vistas a conter a expansão do lixão, a solicitação do licenciamento ambiental da área em questão e a revitalização da Usina de Triagem por meio do convênio com a FUNASA, para obras de reforma e ampliação da Usina e para compra de equipamentos e maquinários.

No dia 07 de janeiro de 2011, o Ministério Público do Estado do Rio de Janeiro, por intermédio da Promotoria de Justiça de Tutela Coletiva do Núcleo de Cabo Frio, veio, nos autos da Ação Civil Pública, pedir vista dos autos em 
referência para posterior manifestação. Após análise, em 11 de setembro de 2011, O Ministério Público do Estado do Rio de Janeiro veio à presença do juiz, aduzir os seguintes fundamentos.

O Ministério Público ajuizou ação civil pública com pedido liminar para interromper o despejo de resíduos sólidos em área de restinga no Município de Arraial do Cabo, que ocasionava degradante processo ambiental e riscos sanitários.

O Ministério Público do Estado do Rio de Janeiro anexou aos autos inúmeras petições e laudos de inspeção oriundos do MP e do INEA, o último datado de 14/02/2009, demonstrando a persistência do grave problema ambiental confessado pelo Réu Município ao contestar a ação, não havendo, portanto, dúvidas quanto à veracidade dos fatos que deram suporte, sendo certo que a ECATUR deveria ter sua revelia decretada por ausência de resposta tempestiva.

O Ministério Público do Estado do Rio de Janeiro alegou que o Município apresentou resposta indicando as medidas que estaria providenciando para a remediação do lixão, a implantação de aterro sanitário e do programa de coleta seletiva, no entanto não apresentou nada referente ao plano efetivo de recuperação da área a ser licenciada pelo INEA, bem como qualquer medida para deflagrar a regulamentação dos planos municipais integrados de gerenciamento de resíduos domiciliares, de saúde e da construção civil.

Alegou também que no decurso da presente ação foi promulgada a Lei $n^{\circ}$ 12.305/10, que instituiu a Política Nacional de Resíduos Sólidos, estabelecendo a obrigatoriedade já antes prevista na Lei no 11.445/07, que instituiu a Política Nacional de Saneamento e normas técnicas ambientais, que previam a destinação e disposição finais ambientalmente adequadas.

O Ministério Público do Estado do Rio de Janeiro argumentou ainda que o Município comprovou nos autos com notas fiscais a destinação dos resíduos de saúde ao Aterro licenciado pelo INEA, mas os demais itens da liminar não foram devidamente cumpridos, restando uma análise do INEA atualizada. Além disso, ressaltou que o Estado do Rio de Janeiro iniciou o programa estadual Lixão Zero, e com ele tem fornecido o apoio técnico e operacional para que os Municípios possam construir seus planos municipais e solucionar o problema, mas o município sequer iniciou essa ação. 
Diante do exposto, o Ministério Público do Estado do Rio de Janeiro requereu em provas a determinação de uma nova vistoria pelo INEA ao local de destinação irregular final dos resíduos sólidos de Arraial do Cabo, devendo responder se fora emitida licença para ampliação e funcionamento da Usina de Triagem e se em relação aos resíduos de construção civil e aos resíduos de saúde estavam sendo cumpridas as Resoluções CONAMA 307 de 05 de julho de 2002 e 358 de 29 de abril de 2005 respectivamente.

O Ministério Público finalizou ressaltando que a possibilidade de criação de consórcio para aterro regional licenciado não afastava a urgente necessidade de adotar medidas de regularização dos serviços de coleta, tratamento e destinação de resíduos sólidos, seja com vistas ao controle ambiental até a implantação do aterro regional, seja com o fim de compatibilizar as atividades presentes ao futuro e incerto aterro consorciado.

Sendo assim, requereu que fosse decretada a revelia dos segundo e terceiro réus, que fossem deferidas as provas requisitadas ao INEA e que fossem julgados procedentes integralmente os pedidos iniciais.

Em 2012, a gestão anterior foi reeleita. Em 20 de janeiro de 2012, o Ministério Público do Estado do Rio de Janeiro requereu vista dos autos.

Paralelamente à batalha jurídica, o município, após o cumprimento das exigências da FUNASA, tornou-se apto a receber os recursos do convênio 0848/2009, em setembro de 2012, referente à primeira parcela de três, sendo que o recebimento das subsequentes estava condicionado à apresentação dos relatórios da obra, bem como à autorização do representante da instituição após visita técnica e aprovação.

A primeira parte executada da obra foi a terraplanagem do terreno, que consistiu na operação de conformá-lo ao gabarito definido no projeto de engenharia. Dessa maneira realizou-se um conjunto de operações de escavação, carga, transporte, descarga, espalhamento, compactação e acabamento, com o objetivo de remover a terra de onde ela se encontrava em excesso para onde faltava, de modo a executar o nivelamento do terreno. 
Figura 23: Início das obras de reforma e ampliação da Usina de Reciclagem.

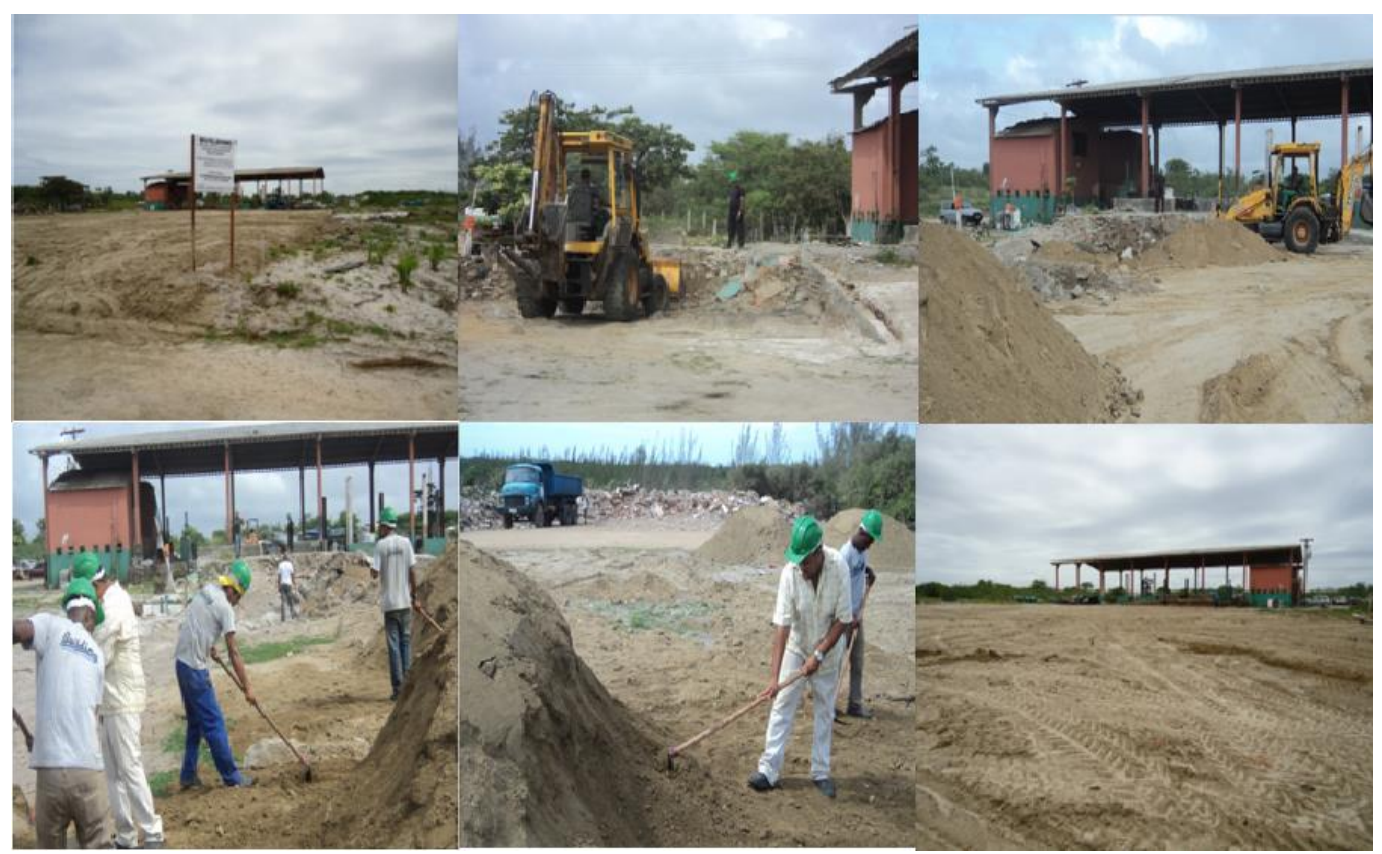

Fonte: Rodrigo Branco, outubro de 2012.

Ainda no ano de 2012, foi realizada pelo Tribunal de Contas do Estado do Rio de Janeiro - TCE/RJ uma Auditoria Governamental na Prefeitura de Arraial do Cabo, no âmbito do tema Resíduos Sólidos para verificar as condições de organização e funcionamento dos serviços de limpeza urbana e manejo dos resíduos sólidos, conforme definido no Plano Anual de Auditoria Governamental PAAG 2013 (Processo TCE/RJ n 303.761-3/12) no que tange ao planejamento e organização, coleta de resíduos urbanos e de serviço de saúde e sua destinação final.

No dia 11 de janeiro de 2013, o Ministério Público do Estado do Rio de Janeiro, por intermédio da Promotoria de Justiça de Tutela Coletiva do Núcleo de Cabo Frio, nos autos do processo, requereu o prosseguimento do feito, tendo em vista que, de acordo com a consulta processual realizada no sítio do Tribunal de Justiça, o mesmo encontrava-se paralisado desde 26 de julho de 2012.

Em atendimento às solicitações do Ministério Público, o INEA realizou vistoria no dia 23 de janeiro de 2013 na Usina de Reciclagem e Compostagem e no lixão do Município de Arraial do Cabo.

$\mathrm{Na}$ vistoria o INEA constatou que a Usina de Reciclagem de Resíduos Sólidos do Município de Arraial do Cabo obteve uma grande conquista, a saber: a Licença Ambiental Simplifica- LAS n ${ }^{\circ}$ INO16871 com validade até 16 de junho de 2016. Constatou que Usina de Reciclagem estava em processo de reforma e 
ampliação, que a operação de compostagem encontrava-se desativada e que o lixão estava sendo utilizado como Estação de Transbordo dos resíduos sólidos urbanos, sem nenhum tipo de tratamento, até a retirada dos mesmos para serem destinados no Aterro Sanitário de São Pedro da Aldeia, propiciando assim a contaminação do solo e das águas superficiais e subterrâneas e a proliferação de doenças veiculadas por vetores como a mosca doméstica, mosquitos, baratas e roedores.

A vistoria constatou também a presença de chorume, o efluente oriundo da decomposição dos resíduos sólidos e com alta carga poluente, além de pneus, carcaças de carros e embarcações depositados a céu aberto.

Em relação aos resíduos de saúde (Classe I — Perigosos -NBR 10004, NBR 10157, NBR 12808 e NBR 12809) foi observado que eram destinados ao Aterro Sanitário de São Pedro da Aldeia, onde ocorria o sistema de tratamento por autoclave, ou seja, tratamento térmico mantendo o material contaminado sob pressão a uma temperatura elevada, em contato com o vapor d' água até a destruição dos segmentos patogênicos, sendo depois os resíduos triturados e depositados na célula do aterro sanitário.

$\mathrm{Na}$ vistoria verificou-se ainda que os resíduos sólidos da construção civil eram depositados em vários locais do lixão, mas também na estrada de acesso ao lixão.

Por fim, a vistoria ressaltou os riscos ao tráfego aéreo, tendo em vista que o aeroporto de Cabo Frio se encontrava a aproximadamente $2.700 \mathrm{~m}$ da área em questão, podendo ter suas atividades operacionais prejudicadas pelo risco potencial causado pela grande presença de aves, entre elas, urubus e garças provenientes do lixão.

Em 04 de março de 2013, após recebimento do relatório da vistoria efetuado pelo INEA, a Ministério Público considerando a postura dos Segundo e Terceiro Réu e a desídia do Município de Arraial do Cabo em dar cumprimento à liminar concedida, requereu imediato julgamento do feito, considerando procedentes os pedidos formulados na inicial, reiterando-se todos os termos das manifestações ministeriais anteriores e valendo-se a presente manifestação como alegações finais.

No dia 08 de março de 2013, o engenheiro Paulo Roberto Correa Fritsch, responsável pela Coordenação Regional da FUNASA em parecer técnico 
constatou o término da terraplanagem do terreno e o início da construção civil, que ficou concentrada na construção do Prédio de Apoio Administrativo, sendo executada toda a infra e superestrutura, assim como toda a alvenaria.

Segundo a Prefeitura, a opção em iniciar pelo prédio de apoio administrativo, que abrigaria não apenas a parte administrativa da Usina de Reciclagem, mas também os vestiários masculino e feminino, a copa, cozinha e o novo refeitório, deveu-se à necessidade de propiciar meios que garantissem melhores condições e maior dignidade ao trabalho dos catadores e das catadoras, pois a estrutura anterior era pequena, pouco arejada e insalubre.

Figura 24: Construção do Prédio Administrativo.

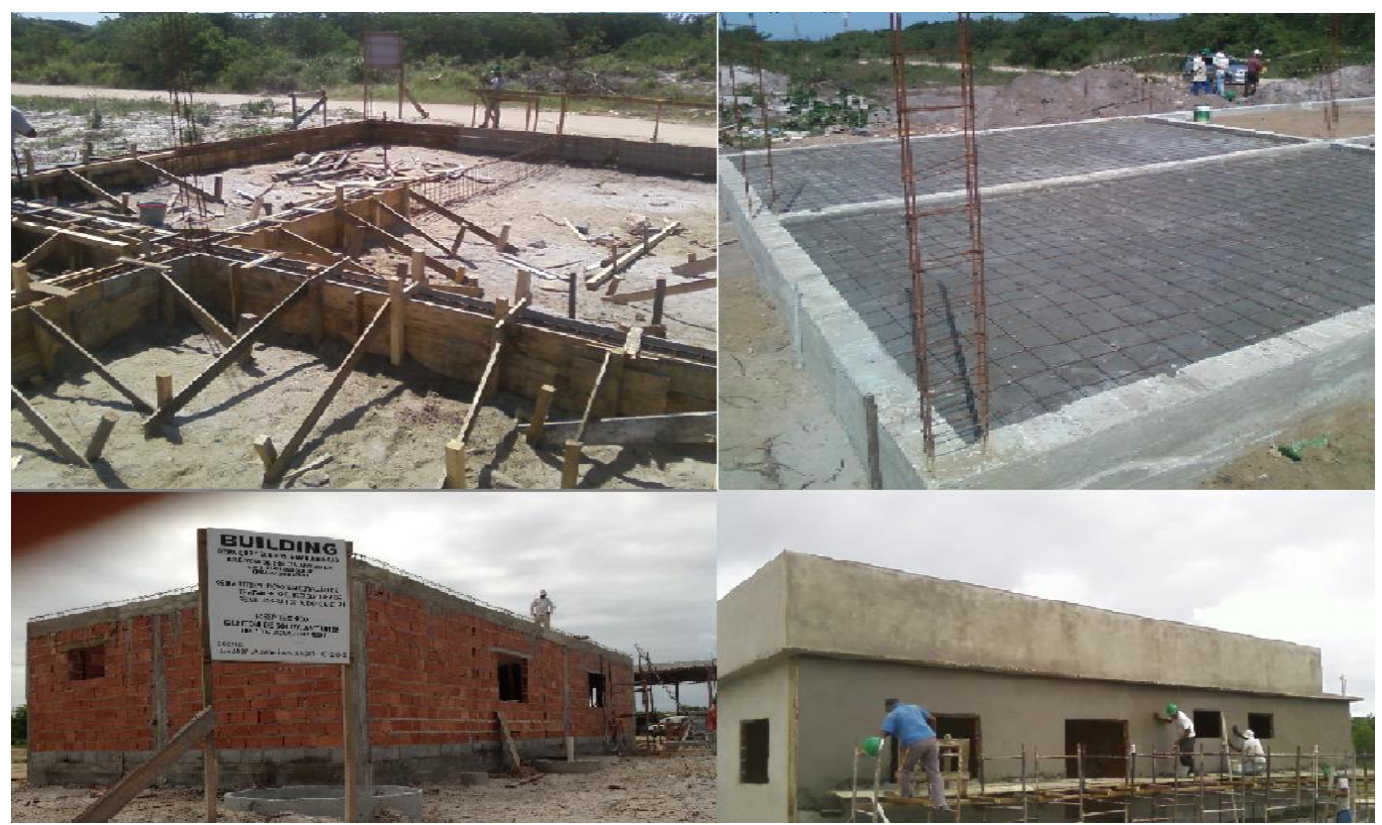

Fonte: Rodrigo Branco, março de 2013.

Em 23 de maio de 2013, o Ministério Público Federal, por meio da Procuradoria da República no Município de São Pedro da Aldeia recebeu denúncia sobre irregularidades pelo descarte de "lixo" e entulho em Área de Preservação Permanente na Praia Grande, município de Arraial do Cabo.

Área de preservação ambiental localizada na Praia Grande se tornou o mais novo lixão da cidade e foi transformada em ponto de descarte de entulho e lixo. Quem passa pela entrada da Área de Preservação Ambiental na Restinga da Massambaba, na Avenida Hermes Barcelos, flagra o descarte de entulho e lixo a poucos metros de um condomínio residencial e Empresa de Saneamento de Arraial do Cabo - ESAC, na Praia Grande. O lugar, que deveria ser preservado pela prefeitura está servindo de ponto de descarte de entulho, galhadas, restos de construção e lixo, sem qualquer critério e separação. Moradores das proximidades, que não quiseram se identificar, informaram que no lixão a céu 
aberto há homens, mulheres e crianças que sem nenhuma proteção catam matérias recicláveis no meio do lixo todos os dias. Eles afirmam que boa parte dos resíduos coletados na cidade acaba indo parar nesse terreno dentro da restinga. Sem contar que atrai urubus, insetos e ratos. $O$ mau cheiro pode ser sentido a mais de $1 \mathrm{~km}$. O lixo está se formando dentro da APA e não existe nenhuma cerca de isolamento ou placa proibindo a entrada de pessoas não autorizadas no local. Diariamente, podem ser avistados na região, além de catadores de lixo, cavalos, urubus e vários casebres de papelão e madeira. A denúncia é grave e deve ser investigada pelos órgãos de proteção ambiental (ICMBio, INEA e IBAMA), bem como pelo Ministério Público Estadual. Esperam-se da Prefeitura Municipal de Arraial do Cabo, através do secretário David Aguiar esclarecimentos sobre esse fato registrado por nossa câmera. A Secretaria Municipal do Ambiente e a de Serviços Públicos deveriam colocar fiscalização no local para impedirem que parte da reserva se transforme em um depósito de lixo a céu aberto, principalmente se tratando de uma área de preservação ambiental. Nada está sendo feito para preservar o local e tudo contribui para a degradação. Somente uma fiscalização rigorosa poderia frear aos instintos de quem se aproveita da incompetência dos órgãos municipais para fazer de uma área de preservação uma imensa lixeira com a cumplicidade do poder público. Enquanto isso, o lixo se acumula por toda a área de preservação, que por conta do descaso da prefeitura, agora não passa de um lixão, que aumenta cada vez mais. (Ação Civil Pública nº 0000412-67.2007.8.19.0005, p. 518).

No dia 24 de maio de 2013, a Comissão Especial presidida pela Deputada J. R. do PSOL, criada para acompanhar e fiscalizar, no Estado do Rio de Janeiro, o cumprimento da lei $\mathrm{n}^{\mathrm{o}} 12.305$, de 02 de agosto de 2010, em especial no que diz respeito à criação de novos aterros sanitários, ao fechamento dos antigos lixões e à implantação de políticas públicas de inclusão social e de reparação aos catadores de materiais recicláveis e seus familiares vistoriou o lixão de Arraial do Cabo e constatou um conjunto de irregularidades. 
Figura 25: Vistoria da Comissão Especial da ALERJ, em 24 de maio de 2013 no lixão de Arraial do Cabo.

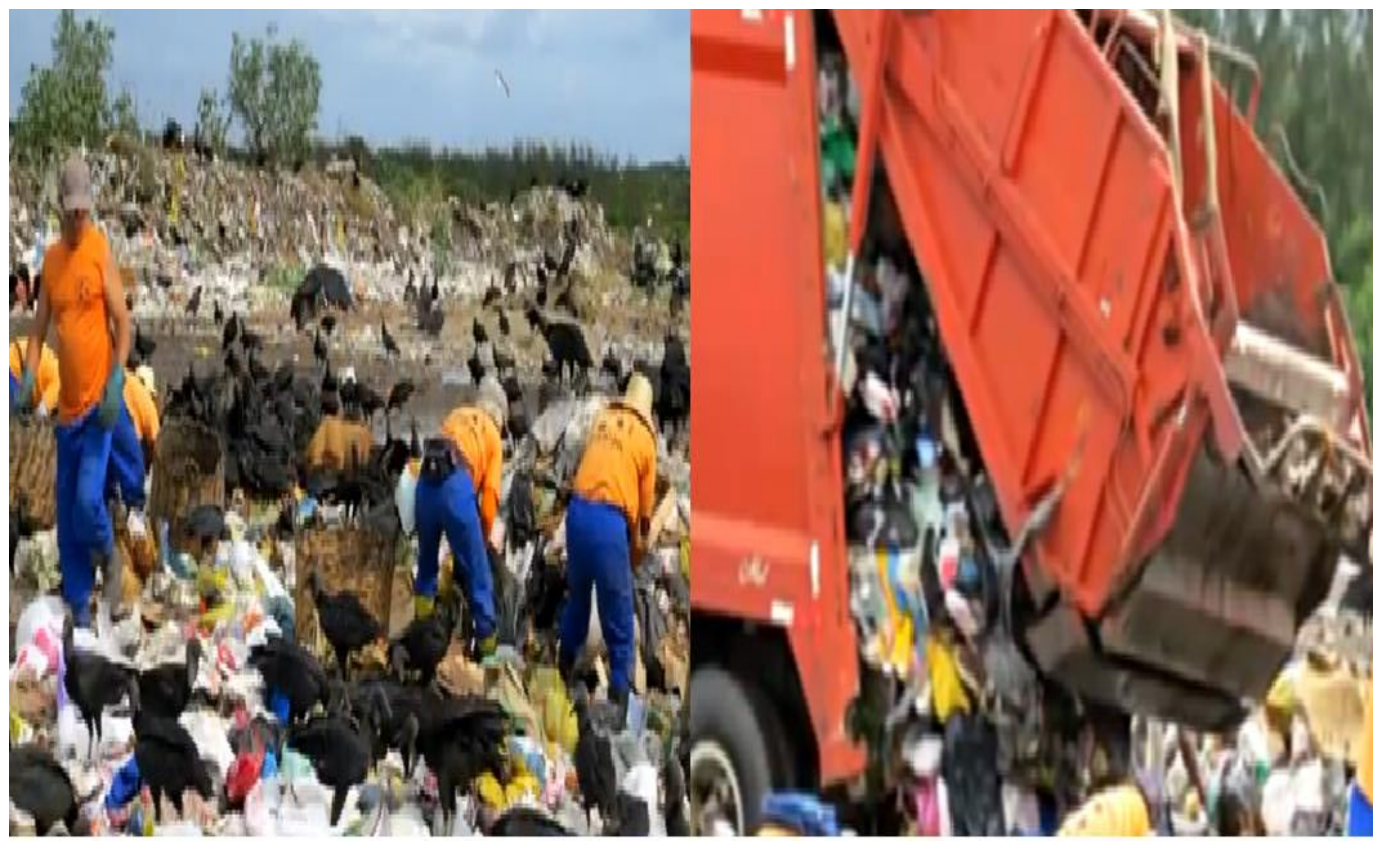

Fonte: TV Maré.

Segundo a deputada J. R. o quadro visto era o seguinte:

Há crimes para todos dos lados, mas não vou dizer que é um crime só da prefeitura porque é um quadro estadual. Existe a responsabilidade da prefeitura, como existe a estadual e a federal. Existe o tratamento do lixo da região que é feito em São Pedro da Aldeia, mas não existe como ter o tratamento do lixo em São Pedro da Aldeia que não seja articulado com o fechamento dos lixões. Aqui é dado como um lixão fechado e como vocês podem ver não é um lixão fechado. Esta dentro de área se não de preservação muito próximo a preservação, sem nenhum tratamento de chorume, o que significa que esse chorume afeta a área de preservação ambiental. Nós temos aqui duas situações graves em relação aos catadores. Por um lado, temos uma cooperativa que não é autossustentada, que é gerenciada pela prefeitura (...). Do outro você tem pessoas que não tiveram acesso a nada. De um lado, você vê uma cooperativa que tem acesso a equipamentos, alimentação, você tem uma política direcionada e do outro lado, você tem o abandono e o medo. A Comissão vai acionar todos os órgãos públicos no sentido de exigir que a Lei Nacional de Resíduos Sólidos seja cumprida e que de imediato essa situação seja cessada. Em relação aos catadores, nós queremos ir além, nós queremos pegar a lei e obrigar as empresas, os governos, tanto o federal como o estadual e como as prefeituras a cumprirem os acordos que tinham sido estabelecidos antes. (Janira Rocha em entrevista a TV Maré).

No dia 12 de junho de 2013, o TCE do Rio de Janeiro em decorrência da Auditoria Governamental na Prefeitura de Arraial do Cabo, no âmbito dos Resíduos Sólidos, após visitas à sede da Prefeitura e com base no exame de dados 
e documentos fornecidos pelo jurisdicionado, concluiu que o município possuía um planejamento inadequado da gestão dos resíduos, que havia a ausência de plano de gerenciamento de resíduos de serviços de saúde para unidades administradas pelo município, que existia um controle impróprio dos serviços prestados, uma prestação inadequada de serviços de coleta de resíduos e o descumprimento de contrato de coleta de resíduos sólidos.

No que tange ao planejamento o TCE/RJ verificou se o município obedecia às orientações da PNRS, se a coleta, a destinação e a disposição finais de resíduos sólidos estavam de acordo com as exigências técnicas, legais e ambientais. Em relação ao planejamento da gestão dos resíduos o TCE/RJ arguiu que a metodologia era inadequada para a apuração do quantitativo anual de resíduos domiciliares, do serviço de limpeza urbana e dos resíduos de serviço de saúde coletados.

Tal fato, segundo o TCE, era decorrente da inexistência do Plano Municipal de Resíduos Sólidos, que permitiria registrar a situação dos resíduos gerados no município, com informações sobre a sua origem, volume, caracterização e formas corretas para a sua destinação e disposição finais. Além disso, permitiria criar um sistema de cálculo de custos da prestação de serviços públicos de limpeza urbana e de manejo de resíduos.

Como consequência, ressaltou o TCE, o município poderia subdimensionar ou superestimar a quantidade de resíduos gerados no município, os gastos necessários com a prestação dos serviços e estabelecer metas irreais na gestão dos resíduos. Sendo assim, propôs a elaboração de um diagnóstico da situação dos resíduos gerados, com base em levantamentos completos sobre os locais adequados de destinação e o estabelecimento de um Plano Municipal de Resíduos Sólidos.

Em relação à ausência de Plano de Gerenciamento de Resíduos de Serviços de Saúde para as Unidades Administradas pelo Município, o TCE salientou sobre os riscos de contaminação ambiental e dos trabalhadores devido à adoção de procedimentos inadequados de acondicionamento, coleta, transporte, tratamento e destinação final. Como solução, propôs o estabelecimento de um Plano de Gerenciamento de Resíduos de Serviços de Saúde com base em orientações dos órgãos pertencentes ao Sistema Nacional do Meio Ambiente, ao Sistema Nacional de Vigilância Sanitária e da Associação Brasileira de Normas Técnicas. 
Sobre o controle inadequado dos serviços prestados, o TCE concluiu que a fiscalização não mantinha registros próprios do cumprimento da programação estabelecida para a coleta de resíduos sólidos e dos resíduos de serviços de saúde, nem tampouco do transbordo dos resíduos na unidade de transferência.

Como desdobramento haveria, segundo o TCE, gastos acima dos necessários para executar os serviços, o pagamento por serviços feitos de forma parcial, além de baixa qualidade. Neste contexto, sugeriu estabelecer uma sistemática de controle dos serviços prestados visando à identificação e à correção de falhas e irregularidades, assim como a melhoria contínua dos serviços, com base em parâmetros estabelecidos pela Associação Brasileira de Normas Técnicas.

No que concerne à prestação inadequada de serviços, o TCE relatou a existência de trabalhadores sem colete refletor para a coleta noturna e de trabalhadores utilizando roupas em tecidos de baixa resistência, ou seja, a inexistência ou precariedade na utilização de Equipamentos de Proteção Individual - EPI. Quanto aos veículos utilizados na coleta de resíduos sólidos, o TCE concluiu que havia deficiência, em particular, a existência de veículos sem jogo de cones para sinalização, bandeirolas e pisca-pisca, sem lanternas traseiras suplementares, sem extintor de incêndio extra e sem lanterna pisca-pisca giratório para a coleta noturna em vias de grande circulação. Já no que se refere aos veículos utilizados na coleta de resíduos de serviço de saúde, as falhas eram sobre a não indicação do nome e do telefone da empresa, a inexistência do indicativo dos resíduos transportados e o uso de veículos com mais de cinco anos de uso.

O TCE concluiu que a baixa qualidade dos serviços, o pagamento de serviços em qualidade diferente da especificada, a falta de segurança do trabalhador, a interrupção dos serviços e suas implicações ambientais e sanitárias eram as principais consequências. Para dirimir os problemas encontrados, o TCE propôs estabelecer uma sistemática de controle dos serviços prestados e notificar a empresa para que corrigisse as falhas e irregularidades encontradas.

No dia 24 de julho de 2013, a Prefeitura de Arraial do Cabo, por meio da Procuradoria Municipal, requereu nos autos da ação movida pelo Ministério Público a designação de audiência especial para que as partes pudessem celebrar Termo de Ajuste de Conduta com a finalidade do Município se adequar às normas de destinação de resíduos. 
Em 18 de setembro de 2013, O Ministério Público Estadual, por intermédio da Promotoria de Tutela Coletiva Núcleo Cabo Frio recebeu a representação ${ }^{\circ}$ 201300980754, relativa ao descarte irregular de resíduos sólidos, formando um verdadeiro lixão a céu aberto na Praia Grande, no Município de Arraial do Cabo, em Área de Preservação Ambiental, no Entorno Parque Estadual da Costa do Sol.

Nesse sentido, o Ministério Público requereu o imediato julgamento do feito, em conformidade com todas as suas manifestações anteriores, inclusive no que tange à necessária adoção de medidas emergenciais de regularização dos serviços de coleta, tratamento e destinação dos resíduos sólidos.

O engenheiro Paulo Roberto Correa Fritsch, responsável pela Coordenação Regional da FUNASA, em parecer técnico do dia 04 de outubro de 2013, afirmou que o município estava cumprindo o objeto pactuado, com a execução física da obra compatível com o Plano de Trabalho, com o projeto básico e com o cronograma físico aprovado, além de possuir a licença ambiental e a Anotação de Responsabilidade Técnica - ART de execução da obra, devidamente quitada junto ao CREA.

No parecer técnico salientou que a Prefeitura estava preparando uma Planilha de Rerratificação, sem alteração do valor contratual, pois alguns serviços indispensáveis não estavam previstos na composição do orçamento inicial, como no caso da malha de ferro do piso do Galpão de Resíduos Sólidos da Construção Civil. Salientou ainda que o Prédio de Apoio Administrativo já está concluído e encontrava-se em funcionamento, estando ocupado pelos catadores e catadoras de materiais recicláveis, que não interromperam as suas atividades durante a execução das obras.

Assim, com o cumprimento de todas as etapas e com a execução em aproximadamente em $40 \%$ da meta física da obra, se posicionou de forma favorável à liberação da segunda parcela dos recursos. 
Figura 26: Construção do Prédio Administrativo da Usina de Reciclagem em Arraial do Cabo.

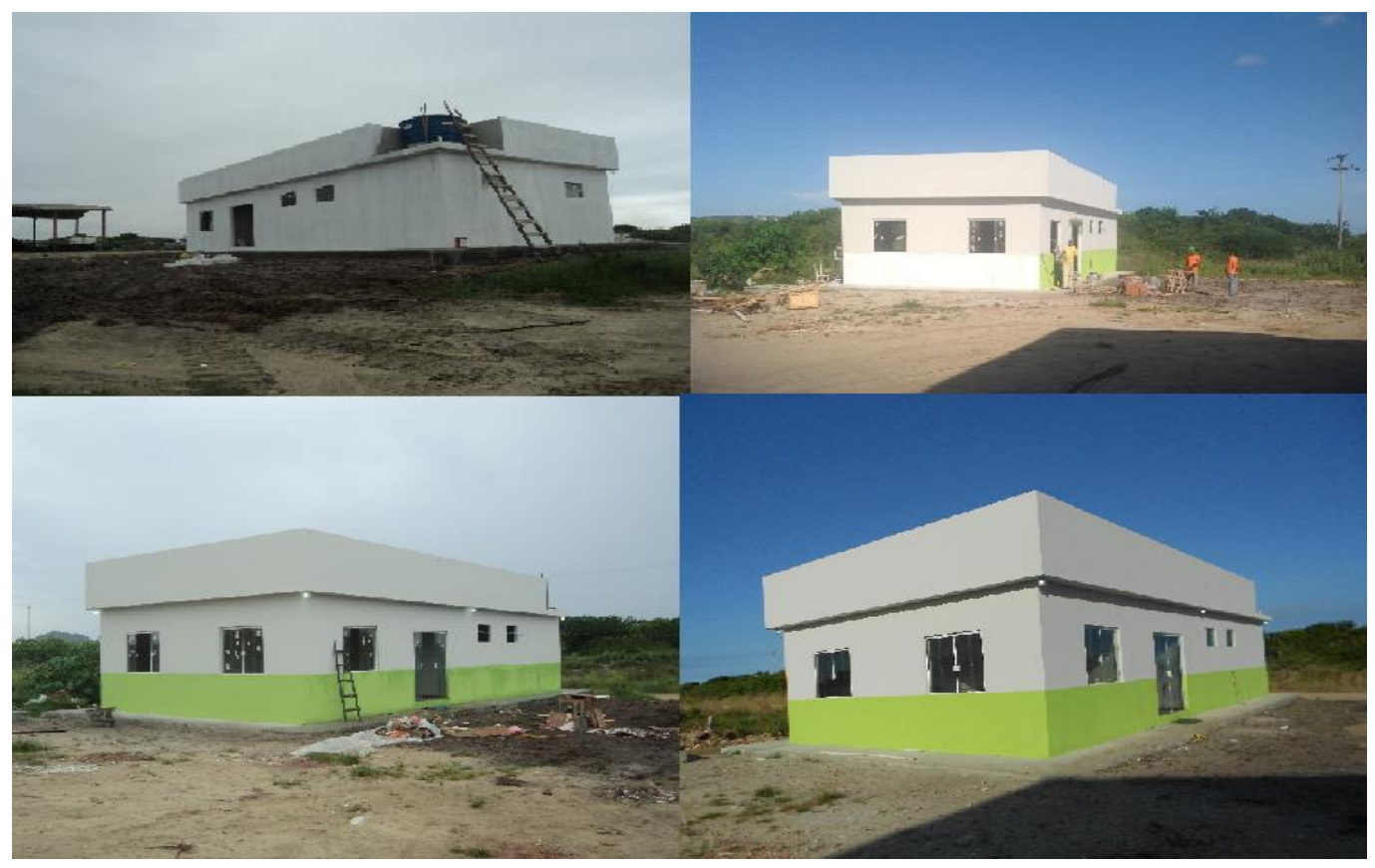

Fonte: Rodrigo Branco, outubro de 2013.

Figura 27: Construção do Prédio Administrativo em Arraial do Cabo.

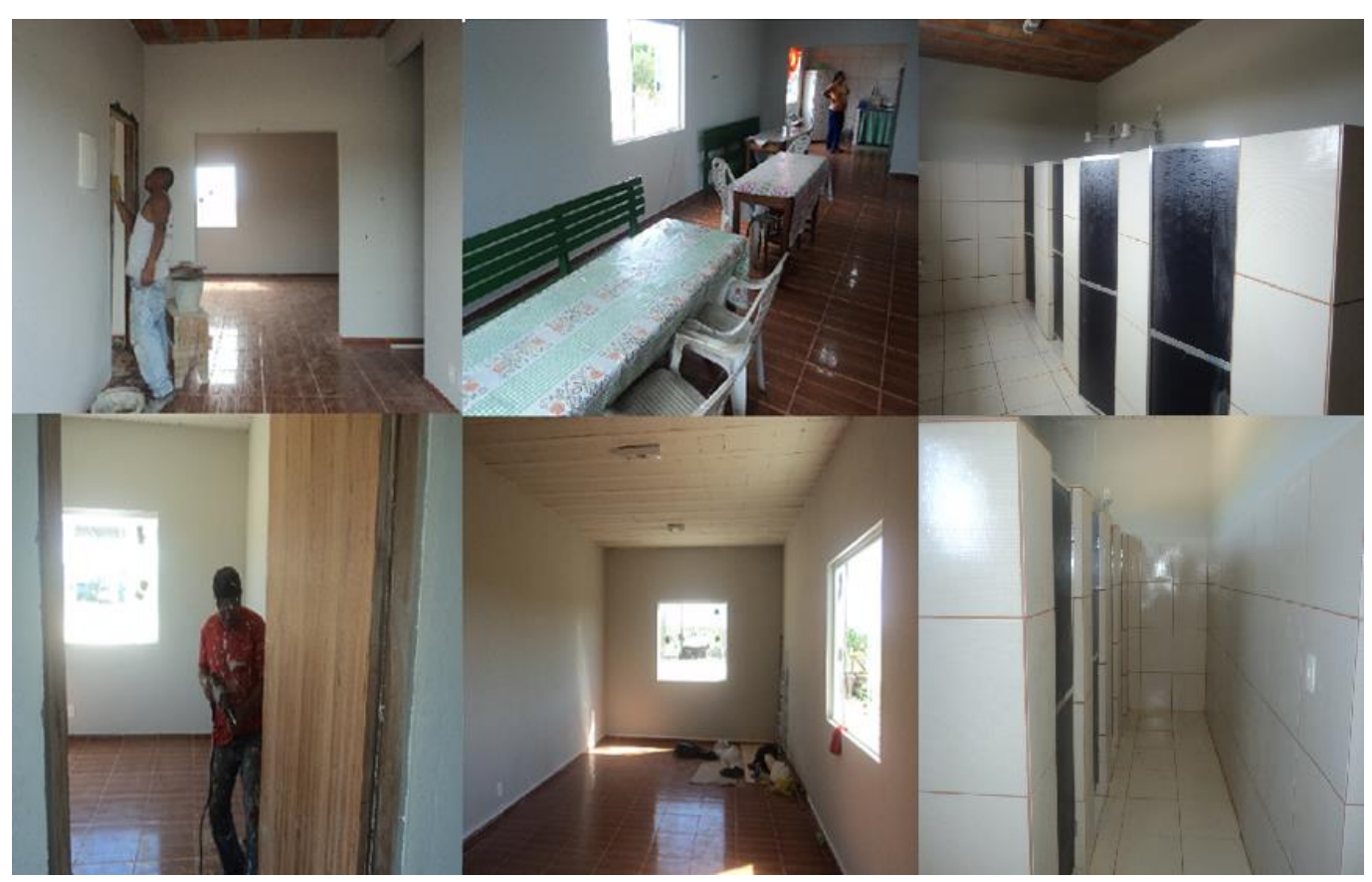

Fonte: Rodrigo Branco, outubro de 2013. 
Figura 28: Prédio Administrativo sendo usado pelos catadores e catadoras da Cooperativa de Coleta e Reciclagem da Costa do Sol.

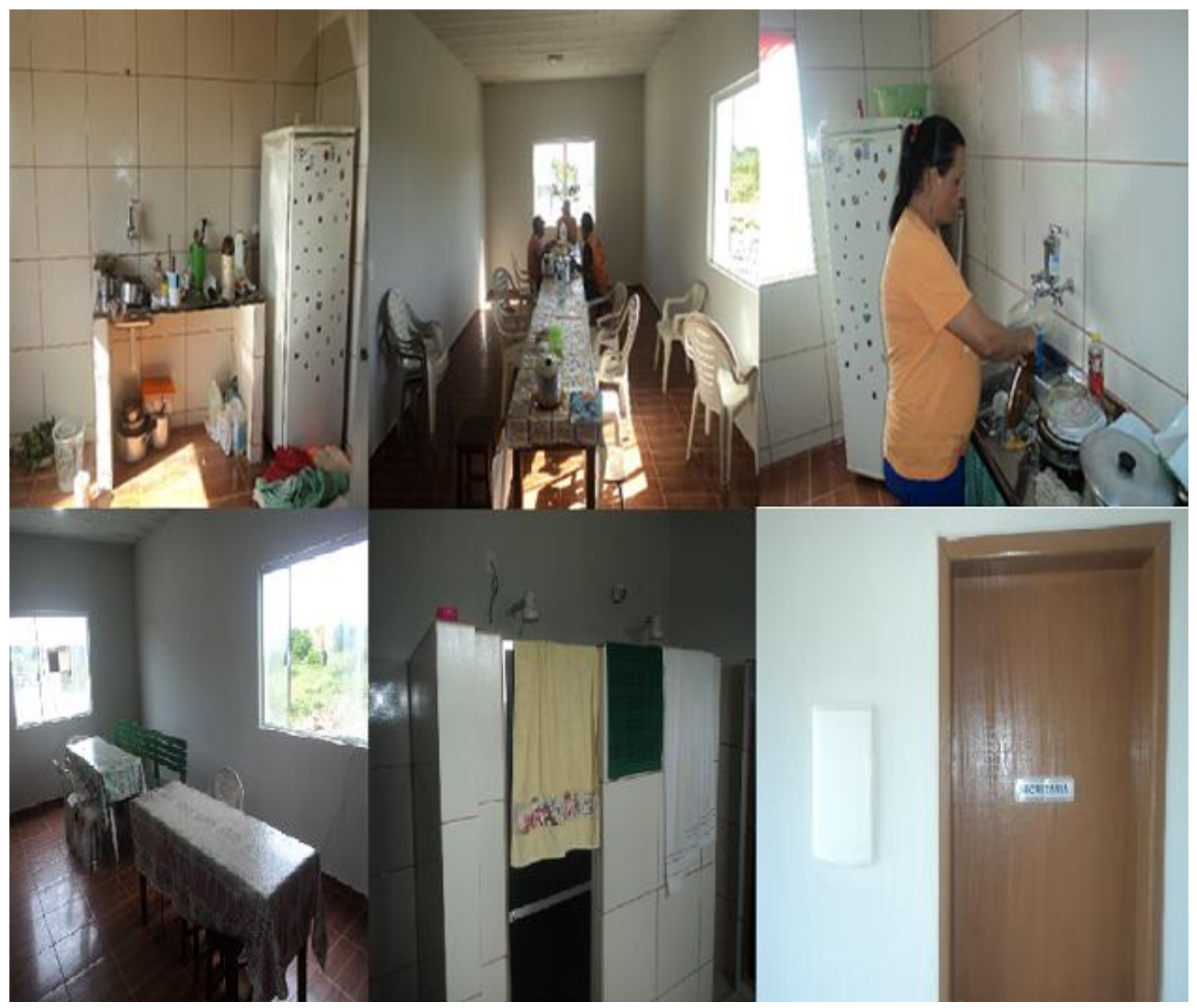

Fonte: Rodrigo Branco, outubro de 2013.

No dia 11 de março de 2014, a Juíza Juliana Gonçalves Figueira Pontes, da Comarca de Arraial do Cabo julgou extinto o processo, com resolução do mérito, na forma do art. 269, inciso I, do CPC, para condenar os réus as seguintes penas:

- O Município de Arraial do Cabo na elaboração e implantação de Programa Municipal de Gerenciamento de Resíduos Sólidos, tendo no mínimo, a elaboração e a execução de Programa Municipal de Coleta Seletiva, do Plano Integrado de Gerenciamento de Resíduos da Construção Civil, a serem definidos em liquidação de sentença;

- O Município de Arraial do Cabo na obrigação de fazer consistente em executar, direta ou indiretamente, Cronograma de Medidas de controle e adequação ambiental para a operação da Usina de Reciclagem e Compostagem de Arraial do Cabo e respectivo vazadouro de resíduos sólidos a ser e apresentado à Fundação Estadual de Engenharia do Meio Ambiente - FEEMA, no prazo de 30 
dias, para fins de prévia aprovação, sob pena de multa diária de $\mathrm{R} \$ 500,00$ (limitada a $\mathrm{R} \$ 50.000,00)$;

- O Município de Arraial do Cabo, a Empresa Cabista de Desenvolvimento Urbano e Turismo - a ECATUR e empresa Emmanuel Teixeira Pontes Serviços, a solidariamente, recuperar a qualidade ambiental da área destinada ao funcionamento de vazadouro de resíduos sólidos e funcionamento da Usina de Reciclagem e Compostagem do Município de Arraial do Cabo, a ser definido em liquidação de sentença;

- Subsidiariamente, em caso de impossibilidade absoluta de renaturalização do ecossistema local, condenar os réus a, solidariamente, executar medidas a serem indicadas pelo órgão estadual de competência ambiental com vistas à recuperação parcial da qualidade ambiental, mitigação dos efeitos ao ecossistema local e compensação pelos danos permanentes, a ser definido em liquidação de sentença.

A juíza ainda condenou os réus ao pagamento das custas e honorários, que fixou em $10 \%$ sobre o valor da condenação, a serem recolhidos para o Fundo Especial do Ministério Público do Estado do Rio de Janeiro, na forma da Lei Estadual n 2.819197, regulamentada pela Resolução PGJ nº 801198 (art. 3 0, XII).

No relatório proveniente da vistoria técnica do dia 07 de maio de 2014, o engenheiro Paulo Roberto Correa Fritsch da FUNASA informou que a Prefeitura de Arraial do Cabo encaminhou, através de e-mail, a Planilha de Rerratificação sem alteração do valor contratual que foi por ele analisada e aprovada.

Ele afirmou que foram necessárias supressões de alguns serviços e a inclusão de novos e acréscimos de quantitativos nos originalmente programados, mas que tais alterações não comprometeram o bom funcionamento da Unidade de Reciclagem.

Ressaltou que foi necessária a construção de nova estrutura em concreto armado para o reservatório elevado, porém, o custo deste novo castelo d'água foi integralmente arcado pela construtora.

Informou que quase toda a parte do convênio relativa às obras de construção civil já fora executada, faltando alguns poucos serviços nos acessos, nas redes externas e no cercamento da área. Informou ainda que para a execução integral do 
objeto pactuado faltava à aquisição dos equipamentos e suas correspondentes instalações.

Sendo assim, pelo observado na visita técnica e pelo percentual de execução do Termo de Compromisso que se encontrava com 68,7\% dos serviços concluídos, se posicionou favoravelmente à liberação da última parcela de recursos.

Figura 29: Entrada da Usina de Reciclagem e do Galpão de Reciclagem em Arraial do Cabo.

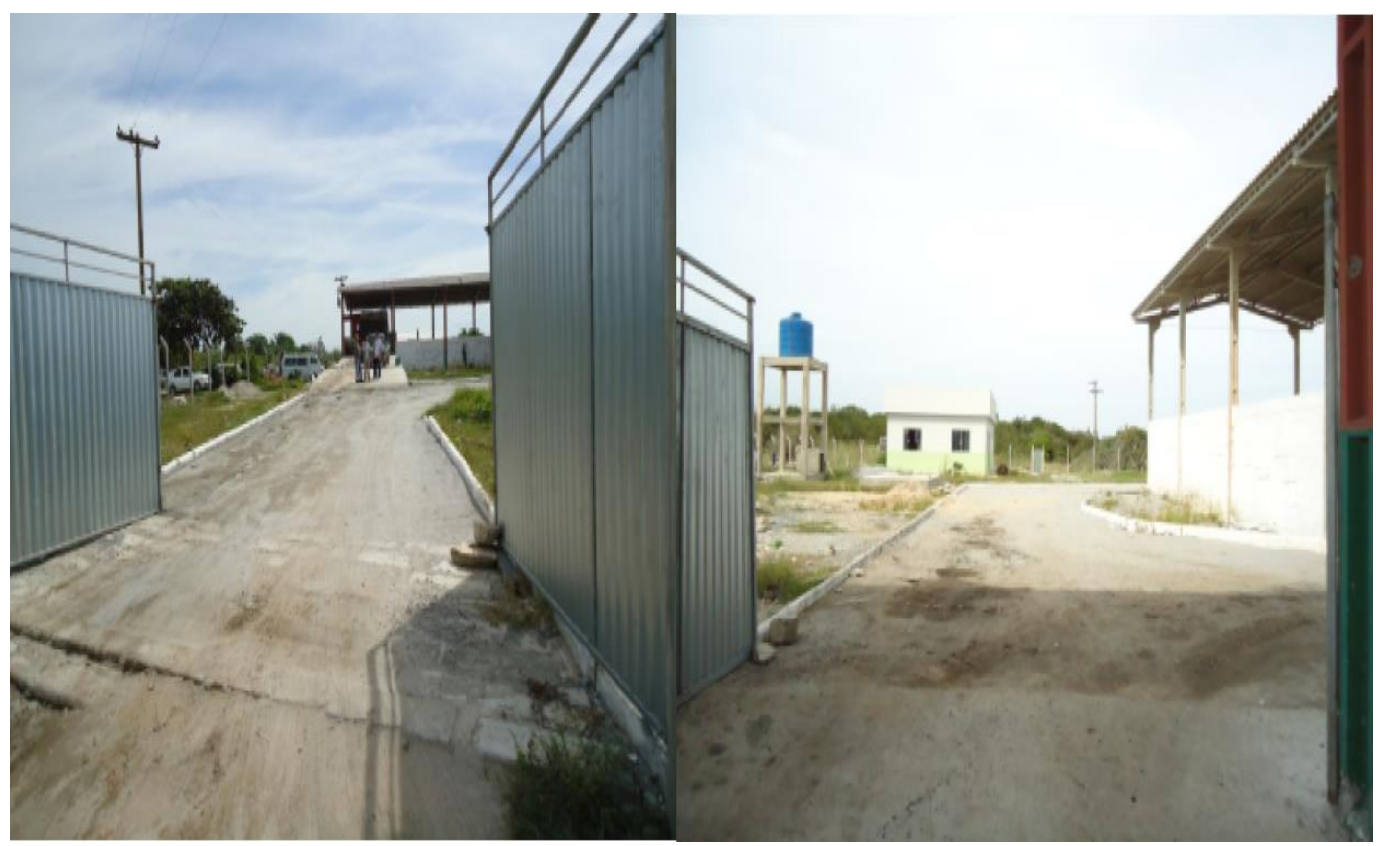

Fonte: Vistoria da FUNASA, maio de 2014. 
Figura 30: Rampa de Acesso ao Galpão de Triagem e o Galpão de Reciclagem de Resíduos da Construção Civil da Usina de Reciclagem em Arraial do Cabo.

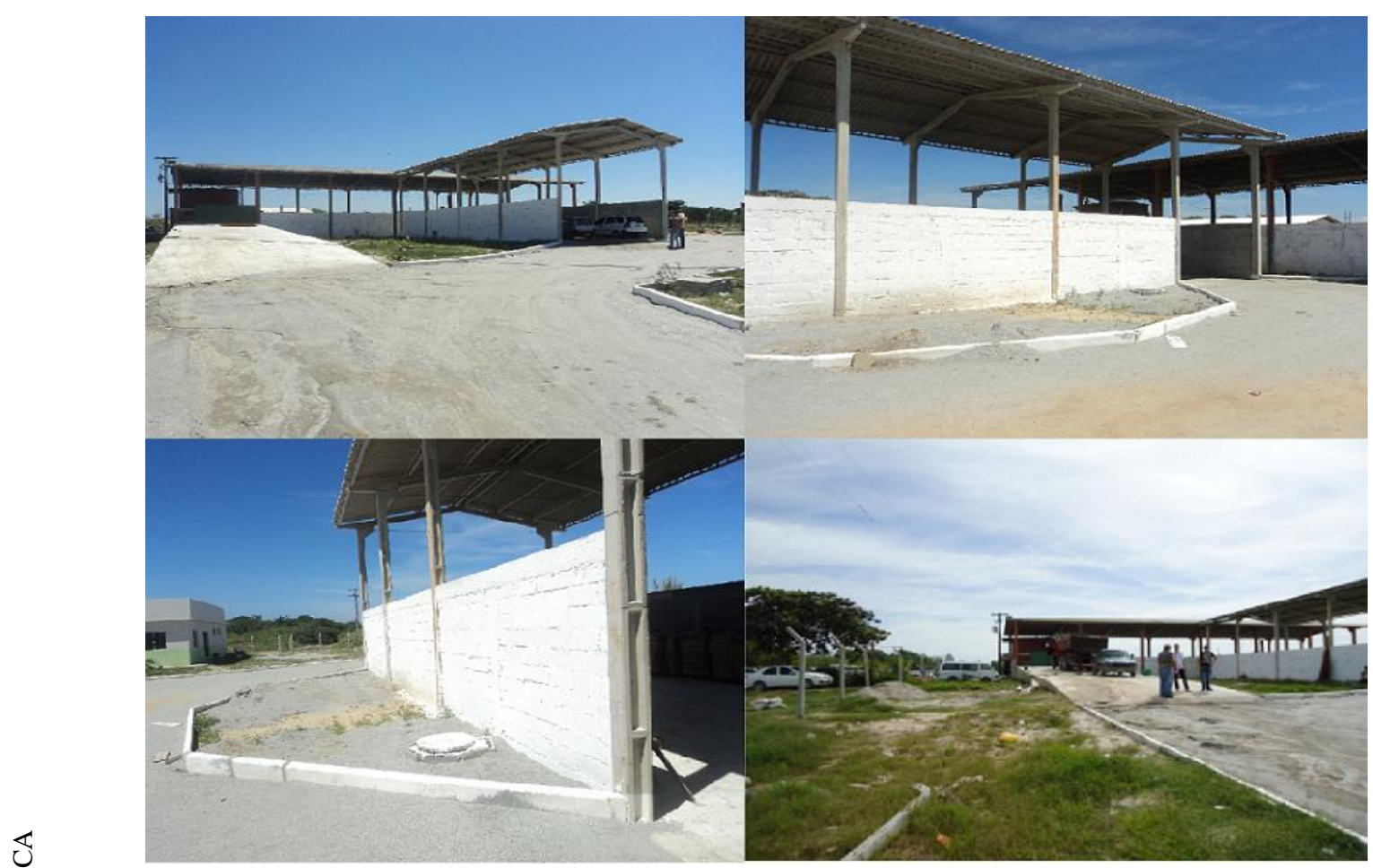

Fonte: Fundação Municipal de Meio Ambiente, Pesquisa, Ciência e Tecnologia, maio de 2014.

Figura 31: Galpão de Triagem da Usina de Reciclagem.

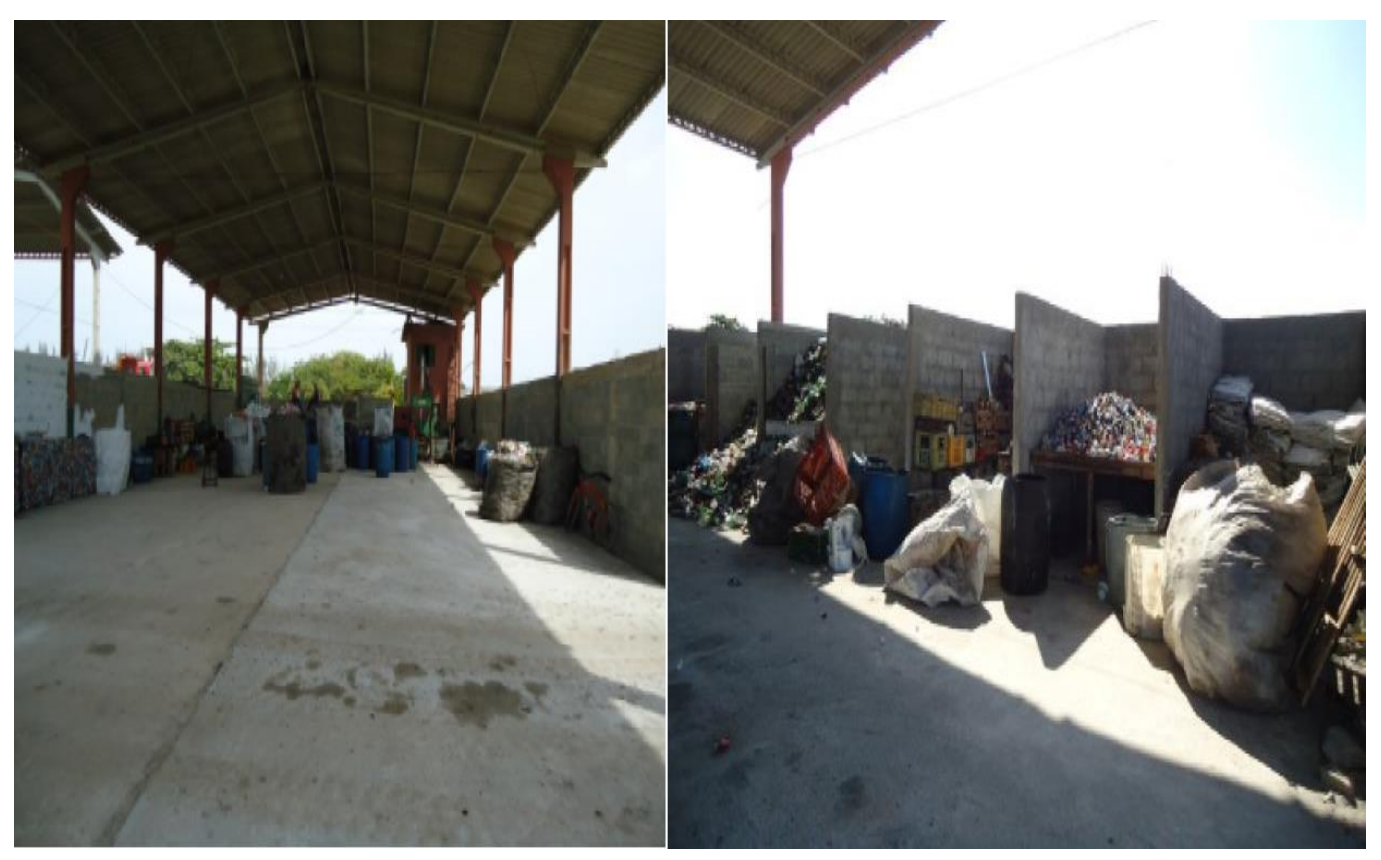

Fonte: Fundação Municipal de Meio Ambiente, Pesquisa, Ciência e Tecnologia, maio de 2014. 
Figura 32: Galpão e Pátio de Compostagem da Usina de Reciclagem em Arraial do Cabo.

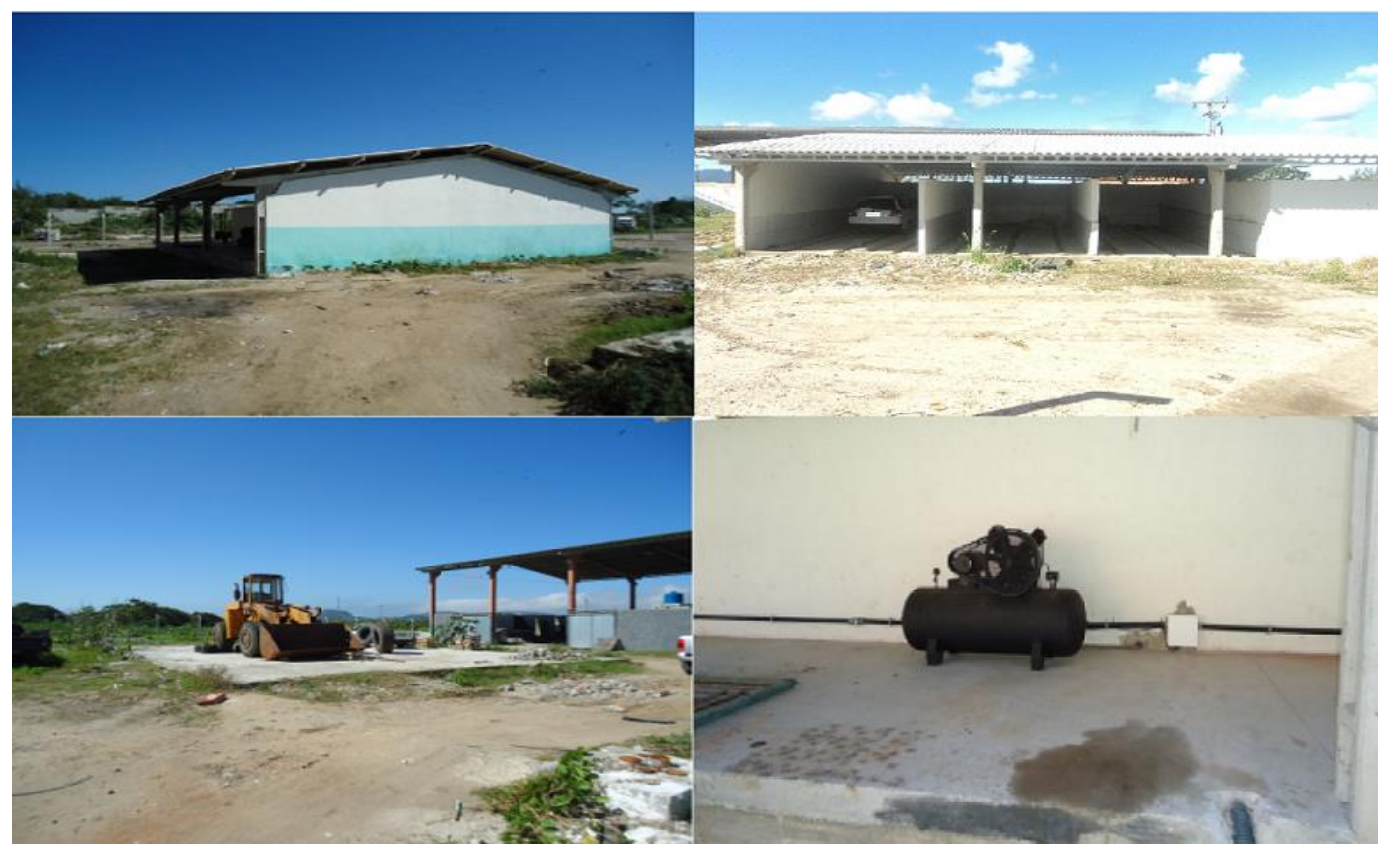

Fonte: Fundação Municipal de Meio Ambiente, Pesquisa, Ciência e Tecnologia, maio de 2014.

Em 13 de maio de 2014, o Ministério Público do Estado do Rio de Janeiro, Promotoria de Justiça de Tutela Coletiva, Núcleo Cabo Frio apresentou tempestivamente, nos autos do processo, exercendo a faculdade prevista nos artigos 535 e seguintes do Código de Processo Civil, embargos de declaração pela apreciação de omissão, por não ter se manifestado o Juízo quanto aos pedidos formulados nos itens iii, iv e v de fls. 20121 da petição inicial. Requereu ainda o esclarecimento da sentença, posto que a FEEMA não existia mais.

Na sentença proferida em 13 de agosto de 2014, a juíza manteve a decisão substituindo a FEEMA pelo INEA e considerou improcedente o pedido no tocante a execução de Plano Integrado de Gerenciamento de Resíduos Sólidos de Saúde.

Em 12 de fevereiro de 2015, o Ministério Público do Estado do Rio de Janeiro, por meio da Promotoria de Justiça de Tutela Coletiva, Núcleo Cabo Frio apresentou apelação em virtude do inconformismo em relação à parte da sentença referente à declaração de improcedência ao pedido da elaboração e à execução de Plano Integrado de Gerenciamento de Resíduos Sólidos de Saúde proferida nos autos da Ação Civil Pública n 0000412-67.2007.8.19.0005.

No relatório de visita técnica realizada em 27 de maio de 2015, o engenheiro Paulo Roberto Correa Fritsch da FUNASA verificou que as obras civis foram executadas conforme pactuado e que a aquisição e instalação dos 
equipamentos da Estação de Triagem, Enfardamento e Estocagem, da Estação de Compostagem e da Estação de Beneficiamento de Resíduos da Construção Civil foram realizadas.

De acordo com o engenheiro responsável pela fiscalização, o Prédio de Apoio Administrativo encontrava-se concluído há mais de um ano e desde então estava sendo utilizado pelos catadores e catadoras da Cooperativa de Coleta e Reciclagem da Costa do Sol, tanto para controle administrativo das tarefas desenvolvidas como para o preparo e deguste das refeições e para a higiene diária dos cooperativados.

Enfatizou que havia a necessidade de pequenos ajustes na esteira de catação do Galpão de Triagem, assim como a limpeza final da obra. Por fim destacou que aguardava a comunicação por parte da fiscalização da Prefeitura sobre a conclusão dos reparos e ajustes para agendar a visita técnica final para verificação mais apurada da conclusão dos objetivos pactuados.

Figura 33: Galpões com os maquinários.

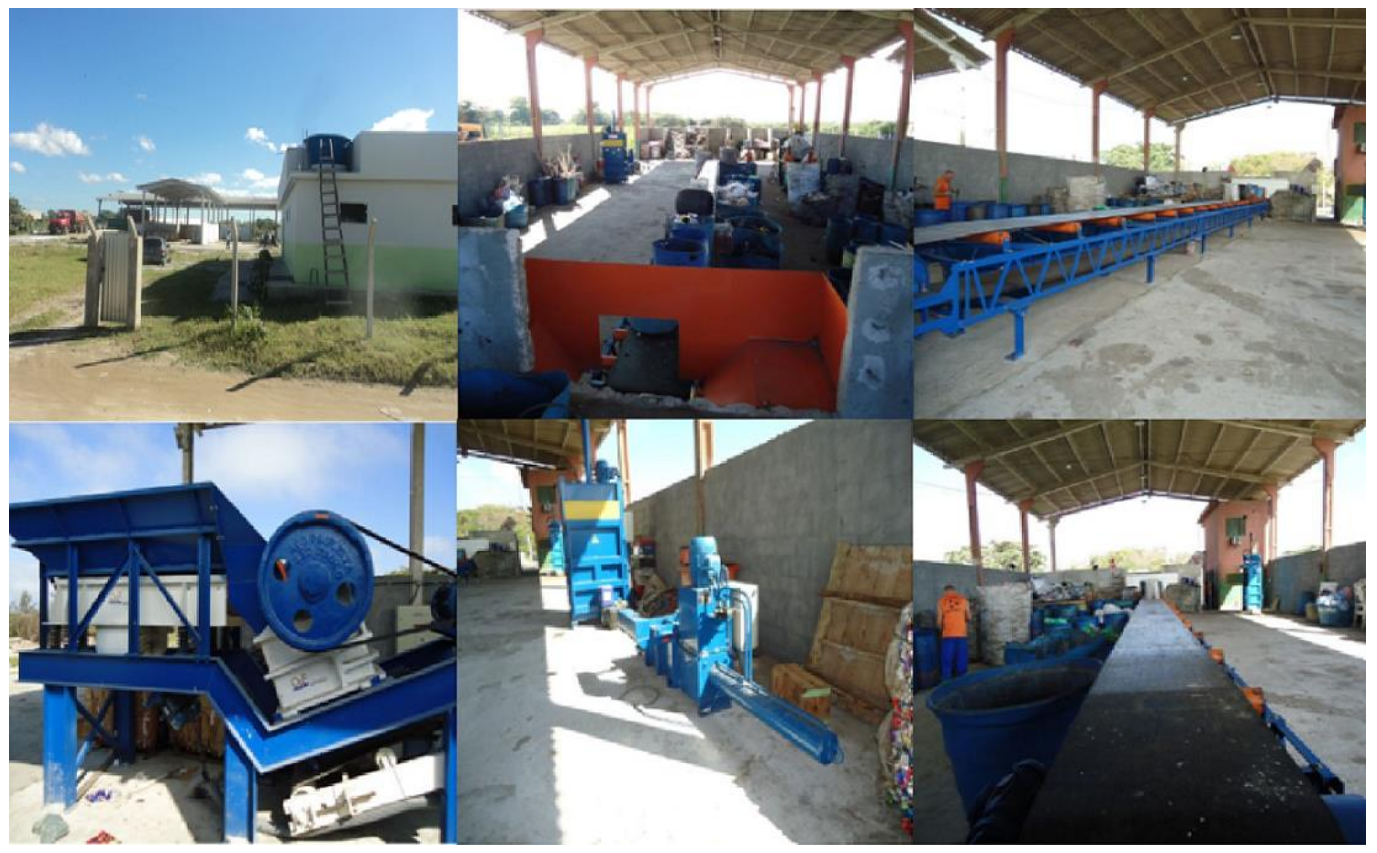

Fonte: Vistoria FUNASA, maio de 2015.

No relatório técnico de 28 de agosto de 2015, o engenheiro Paulo Roberto Correa Fritsch da FUNASA informou que a obra encontrava-se concluída, com todos os serviços executados conforme última planilha de rerratificação aprovada pelo engenheiro fiscal da Prefeitura e com sua anuência, entretanto destacou que 
apesar dos cooperativados trabalharem no local, ainda não estavam utilizando integralmente as instalações ora concluídas.

Destacou que as autoridades do executivo municipal deveriam providenciar o aumento de carga para proporcionar a utilização de todos os equipamentos simultaneamente.

Destacou ainda que, com o intuito de proporcionar uma maior eficiência de todas as unidades que compõem a Usina de Resíduos Sólidos de Arraial do Cabo, ocorreram algumas alterações da planilha inicialmente pactuada, pois alguns equipamentos equivocadamente não foram previstos no projeto. Além disso, alguns serviços técnicos de engenharia foram suprimidos pela maior necessidade de inclusão de outros.

Finalizou o relatório técnico informando que apesar da execução de todos os serviços, o objetivo pactuado no convênio só seria alcançado após o pleno e adequado funcionamento da Estação de Reciclagem de Resíduos Sólidos de Arraial do Cabo, e somente após esta ocorrência iria analisar, verificar e aprovar, sob os aspectos técnicos de engenharia, a prestação de contas final.

No dia 21 de setembro de 2015 o município de Arraial do Cabo, devidamente qualificado, nos autos da Ação Civil Pública proposta pelo Ministério Público do Estado do Rio de Janeiro, veio por seus Procuradores perante o juiz oferecer suas contra razões ao Recurso de Apelação de fls. 490/496.

De acordo com o município, a Apelação referia-se somente ao item "e" da sentença datada de 13 de agosto de 2014, que julgou improcedente o pedido de execução de Plano Integrado de Gerenciamento de Resíduos Sólidos de Saúde.

Ainda segundo o município, a sentença acatada nesse ponto pelo Ministério Público foi clara ao consignar que o Plano Integrado de Gerenciamento de Resíduos Sólidos de Saúde vinha sendo feito de forma satisfatória, dando o Município correta destinação aos resíduos de serviço de saúde, enviando-os ao aterro licenciado pelo INEA em São Pedro da Aldeia, motivo pelo qual o referido pedido foi sabiamente julgado improcedente, o que deveria se manter em julgamento de $2^{\circ}$ grau.

$\mathrm{Na}$ visita técnica realizada nos dias 06 e 07 de outubro de 2016, o engenheiro Paulo Roberto Correa Fritsch da FUNASA, em conversa com os catadores e catadoras e por observação in loco verificou a operação simultânea dos equipamentos da Usina de Reciclagem. 
Segundo o representante da FUNASA os catadores e catadoras informaram estarem satisfeitos com a nova forma de segregação dos resíduos sólidos coletados no município de Arraial do Cabo, pois trocaram o trabalho de catação direta no lixão em posição laboral totalmente inadequada, pela separação dos resíduos em uma posição ergonomicamente correta, além estarem protegidos da exposição solar e das demais intempéries.

Concluiu que os serviços técnicos de engenharia foram executados conforme planilha repactuada, sendo possível afirmar que o objetivo do convênio foi alcançado.

No dia 08 de outubro de 2015, o município de Arraial do Cabo, devidamente qualificado, nos autos da Ação Civil Pública, proposta pelo Ministério Público do Estado do Rio de Janeiro, requereu que a sentença de $1^{\circ}$ grau julgando procedente em parte o pedido para condenar o município de Arraial do Cabo fosse reformada, julgando improcedente os pedidos para desobrigar o município de executar as medidas impostas na sentença de $1^{\circ}$ grau, mantendo-se o julgamento de improcedência do item "e" como já requerido nas contra razões apresentadas pela municipalidade, tendo em vista que não solucionou adequadamente o conflito de interesses, devendo assim ser provido o recurso.

O município, em sua solicitação argumentou que a ação proposta no ano de 2007 vinha sendo julgada após extenso interstício de tempo, portanto quando já havia ocorrido diversas mudanças em relação às situações descritas na inicial. Segundo alegação do município, as mudanças ocorreram em vários campos, desde os problemas relatados, passando pela troca dos gestores municipais até as empresas prestadoras de serviços, inclusive com o réu Emmanuel Teixeira Pontes Serviços não prestando mais serviços para a municipalidade desde o final do ano de 2008.

Argumentou também que, ao condenar o Município nas obrigações de fazer constantes da sentença, além de violar dispositivos legais e constitucionais, estaria intervindo na execução da política orçamentária da Administração Pública, contrariando frontalmente o princípio constitucional da independência e harmonia dos poderes, nos termos do que dispõe o art. $2^{\circ}$ da Constituição Federal e promovendo, por via transversa, a transferência de recursos de outras áreas priorizadas pelo Poder Legislativo e pelo Poder Executivo, por meio da aprovação das Leis Orçamentárias. 
Outra alegação apresentada pelo município referiu-se à violação flagrante ao princípio da reserva do possível, neste particular no que tange a necessidade de previsão orçamentária.

De acordo com o município, em face do princípio da legalidade da despesa pública, ao administrador público é imposta a obrigação de observar as autorizações e os limites constantes nas leis orçamentárias, sob a pena de crime de responsabilidade previsto pelo art. 85 , VI da $\mathrm{CF} / 88$, assim sendo vedado ao administrador realizar qualquer despesa sem previsão orçamentária, nos termos do art. $167,11 \mathrm{da} \mathrm{CF} / 88$.

Prosseguiu argumentando que, por isso, no exame da questão acerca da definição de políticas públicas e da escolha das prioridades orçamentárias, a doutrina tende a defender a não intervenção material do Poder Judiciário, por tratar-se de atividade discricionária do administrador.

O município contestou ainda a aplicabilidade de multa diária em face da Fazenda Pública, alegando que a multa do art. 644 do CPC seria incompatível com a sistemática de atuação dos órgãos públicos.

Em 01 de dezembro de 2015, O Ministério Público do Estado do Rio de Janeiro, por meio da Promotoria de Justiça de Tutela Coletiva, apresentou o ofício recebido da Procuradoria do Trabalho no Município de Cabo Frio para ser encaminhado aos autos, no qual foi noticiado que a Cooperativa de Catadores de Resíduos Sólidos contratada pela Prefeitura de Arraial do Cabo estava trabalhando de forma desumana e insalubre num lixão a céu aberto, contrariando a Lei Federal $\mathrm{n}^{\circ}$ 12.305, de 02 de agosto de 2010, que instituiu a Política Nacional de Resíduos Sólidos, e os Decretos Federais $n^{\circ} 7.404$ e $n^{\circ} 7.405$, que a regulamentavam.

Em 18 de julho de 2016, o Ministério Público do Estado do Rio de Janeiro, por meio da Promotoria de Justiça de Tutela Coletiva do Núcleo Cabo Frio, no uso de suas atribuições legais, com fulcro nos art. 129, inciso III, da Constituição da República, apresentou as contra razões de apelação ao recurso interposto pelo réu Município de Arraial do Cabo.

Baseando-se na legislação ambiental sobre gestão de resíduos sólidos, em particular, na Lei $\mathrm{n}^{\circ}$ 12.305/10, que instituiu a Política Nacional de Resíduos, na Lei Estadual $n^{\circ}$ 4.191/03, que instituiu a Política de Resíduos Sólidos no Estado do Rio de Janeiro, na Resolução CONAMA n 307/02, que instituiu o Plano de Gerenciamento de Resíduos da Construção Civil, na Resolução CONAMA n 358 
de 29 de abril de 2005, que determinou o tratamento e disposição final dos resíduos dos serviços de saúde. Baseando-se ainda no Plano Diretor do Município de Arraial do Cabo, que instituiu a política municipal de saneamento, que determinou o correto acondicionamento, coleta, tratamento e disposição final dos resíduos sólidos, de forma que não tragam prejuízos à saúde, ao bem-estar público e ao meio ambiente, assim como nos documentos acostados à Ação Civil Pública, o Ministério Público contrapôs a alegação do réu da violação da separação dos poderes, da violação ao princípio da reserva do possível - da necessidade de previsão orçamentária e da inaplicabilidade de multa diária, em face da Fazenda Pública.

De acordo com a Promotoria de Justiça de Tutela Coletiva do Núcleo Cabo Frio foram totalmente inverídicas as alegações do réu de que a decisão do juízo violaria o princípio constitucional da separação dos poderes e de que o Poder Judiciário teria usurpado a competência do Poder Executivo em matéria de competência privativa deste, pois o Judiciário estava apenas resguardando o direito da coletividade, face ao descumprimento reiterado pelo Município.

Para a Promotoria a arguição de violação ao princípio constitucional da separação de poderes se constituiu em uma alegação genérica, sem embasamento jurídico e que fora a tempo superado pela jurisprudência do Egrégio TJRJ e dos tribunais superiores (STJ e STF).

Prosseguiu afirmando a Promotoria que no controle jurisdicional de políticas públicas cabe ao Poder Judiciário, a análise da legalidade dos atos dos três poderes constitucionais e, caso haja falha ou deficiência no ato impugnado, afastá-lo e aplicar o procedimento correto a ser seguido.

Sendo assim, não se tratava do Poder Judiciário escolher a prioridade de uma política pública em detrimento de outra ou de interferir na discricionariedade do poder executivo, pois não havia discricionariedade contra direitos consagrados na Constituição, como o direito fundamental ao meio ambiente ecologicamente equilibrado, consagrado no art.225 da Constituição Federal de 1988.

A defesa do réu alegou a violação ao princípio da reserva do possível e da necessidade de previsão orçamentária. Para a Promotoria essa contestação não passou de mais um argumento protelatório porque em nenhuma hipótese o princípio da legalidade orçamentária poderá se sobrepor a garantia do direito fundamental ao meio ambiente ecologicamente equilibrado. 
Além deste fato o argumento de impossibilidade de cumprir as decisões judiciais onerosas aos cofres públicos por falta de alocação de verbas orçamentárias, bem como por suposta violação ao princípio da legalidade orçamentária não se sustentava porque o orçamento não seria estanque, sendo possível o redirecionamento de verbas, ou mesmo a abertura de créditos adicionais para atender as necessidades imprevistas.

Por fim, arguiu a Promotoria que a alegação de inaplicabilidade de multa diária em face da Fazenda Pública, em razão da inexistência de possibilidade de responsabilização da pessoa jurídica de direito público por atos de seus agentes, foi superada.

Ante aos argumentos expostos, requereu o Ministério Público do Estado do Rio de Janeiro, na condição de apelado, conhecimento do recurso apresentado e o não provimento do Recurso de Apelação interposto.

No dia 01 janeiro ano de 2017, assumiu como novo prefeito do município de Arraial do Cabo, Renato Martins Vianna do PRB.

No dia 08 de janeiro de 2017, uma reportagem da Rede InterTV, afiliada à Rede Globo, com sede no município de Cabo frio, fez uma reportagem sobre a disposição de resíduos numa área que fica localizada dentro do Parque Estadual da Costa do Sol, próximo à Praia Grande, em Arraial do Cabo.

Em 03 de março de 2017, o parecer da Procuradoria Geral da Justiça, deu provimento ao recurso do Ministério Público e desprovimento ao recurso interposto pelo município de Arraial do Cabo. A Décima Primeira Câmara Cível, ao apreciar o processo em epígrafe, em sessão realizada em 30 de agosto de 2017, proferiu decisão por unanimidade, dando provimento ao recurso do Ministério Público e negando o provimento ao recurso do município de Arraial do Cabo nos termos do voto do relator.

Na fundamentação da negação ao recurso do município de Arraial do Cabo, $11^{\mathrm{a}}$ Câmara Cível arguiu que não houve a alegada violação ao princípio da separação dos poderes, conforme o entendimento firmado pelo Supremo Tribunal Federal em casos análogos, que permitiu a atuação do Poder Judiciário, para determinar a implantação de políticas públicas, sempre que necessário para garantir os direitos constitucionais essenciais, visto que seria dever do poder público e da sociedade a defesa de um meio ambiente equilibrado. 
No que tange à ofensa à cláusula da reserva do possível, a 11ª Câmara Cível concluiu que seria firme o entendimento da Suprema Corte de que esta não poderá ser invocada para justificar a violação ao mínimo existencial, corolário do princípio da dignidade da pessoa humana.

Por fim, a $11^{\text {a }}$ Câmara Cível determinou que se mantivessem o prazo e a multa estabelecidas na sentença, diante do caráter coercitivo das medidas, pois não poderia frustrar a garantia da efetivação da ordem judicial e, por consequência, o interesse público e a proteção ao meio ambiente em razão dos entraves burocráticos alegados pelo município.

Desta forma, acolheu-se o primeiro recurso para julgar procedente o pedido formulado no item III, à fl. 20 da petição inicial, para que o município de Arraial do Cabo apresentasse no prazo de 03 (três) meses o Plano Integrado de Gerenciamento de Resíduos Sólidos de Saúde, sob pena de multa diária de R \$ 500,00 , limitada a $\mathrm{R} \$ 50.000,00$.

Em 13 de novembro de 2017, a Secretaria da Décima Primeira Câmara Cível certificou que não houve interposição de recursos contra acórdão/decisão retro e no dia 06 de fevereiro de 2018 , na forma prevista no art. $5^{\circ}$, $\S 3^{\circ}$ da lei 11.419/06, o município foi intimado a cumprir o Acórdão.

No dia 08 de fevereiro de 2018, uma equipe da Coordenadoria Integrada de Combate a Crimes Ambientais - CICCA da Secretaria Estadual do Ambiente fez uma operação interditando o lixão de Arraial do Cabo, em função do despejo irregular de "lixo" em uma área de proteção ambiental.

De acordo com site http://www.inea.rj.gov.br/Portal/Noticias/INEA0151298 ao chegarem ao local os técnicos do INEA e os policiais flagraram um caminhão que havia acabado de despejar resíduos da construção civil e outros dois carregados de lixo, além de escavadeira hidráulica que fazia o manejo dos resíduos nessa área, sem nenhuma licença/autorização. A equipe constatou que os veículos prestavam serviço para a Prefeitura de Arraial do Cabo.

Ainda segundo o site, o INEA interditou o lixão clandestino e apreendeu os caminhões e a escavadeira hidráulica, conduzindo os motoristas dos veículos apreendidos à 132 $2^{\mathrm{a}}$ Delegacia de Polícia (Arraial do Cabo) onde prestaram esclarecimentos. A administração municipal local foi autuada e multada por infringir os artigos 85 (operar sem licença/autorização), 90 (poluição por queima de material ao ar livre) e 95 (descarte inadequado de lixo) da lei 3.467/2000. A 
prefeitura também foi notificada a requerer a Licença Ambiental de Recuperação (LAR) e a destinar seus resíduos em local ambientalmente adequado.

Em 26 de fevereiro de 2018, o Ministério Público do Estado do Rio de Janeiro, a fim de satisfazer título executivo judicial, em face do município de Arraial do Cabo, da Empresa Cabista de Desenvolvimento Urbano e Turismo ECATUR e da empresa Emmanuel Teixeira Pontes Serviços, requereu cumprimento da sentença imposta com a intimação do município de Arraial do Cabo para que processasse, dentro do prazo estabelecido, sob pena de execução da multa diária as seguintes obrigações:

- Elaboração e implantação de Programa Municipal de Gerenciamento de Resíduos Sólidos, consubstanciado em, no mínimo, elaboração e execução de Programa Municipal de Coleta Seletiva e de Plano Integrado de Gerenciamento de Resíduos da Construção Civil;

- Apresentasse, no prazo de 03 (três) meses, o Plano Integrado de Gerenciamento de Resíduos de Saúde, sob pena de multa diária de R \$ 500,00, limitada a R \$ 50.000,00, conforme determinado no v. acórdão de fls. 683/389;

- O Município de Arraial do Cabo, a Empresa Cabista de Desenvolvimento Urbano Turismo - da ECATUR e a empresa Emmanuel Teixeira Pontes Serviços para solidariamente, promovessem a execução, direta ou indiretamente, do Cronograma de Medidas de controle e adequação ambiental para a operação da Usina de Reciclagem e Compostagem de Arraial do Cabo e respectivo vazadouro de resíduos sólidos, a ser apresentado ao Instituto Estadual do Ambiente - INEA, no prazo de 30 dias, para fins de prévia aprovação, sob pena de multa diária de $\mathrm{R} \$$ 500,00, limitada a $\mathrm{R} \$ 50.000,00$;

- Depois de cumprido o item anterior, executassem ações devidamente aprovadas pelo INEA objetivando recuperar a qualidade ambiental da área destinada ao funcionamento de vazadouro de resíduos sólidos e o funcionamento da Usina de Reciclagem e Compostagem do Município de Arraial do Cabo;

- Subsidiariamente, em caso de impossibilidade absoluta de renaturalização do ecossistema local, executassem medidas a serem indicadas pelo órgão estadual de competência ambiental com vistas à recuperação parcial da qualidade ambiental, mitigação dos efeitos ao ecossistema local e compensação pelos danos permanentes; 
- O Município de Arraial do Cabo para que informasse, de forma detalhada, o custo de implantação das obrigações de fazer determinadas neste processo, de forma que viabilizasse o cálculo dos honorários a serem revertidos ao MPRJ, eis que fixados em $10 \%$ do valor da condenação pela d. sentença constante do índex 533.

No dia 08 de junho de 2018, o município de Arraial do Cabo recebeu do INEA um caminhão para realizar a coleta seletiva, que faz parte do Programa Coleta Seletiva Solidária (PCSS) do Estado do Rio de Janeiro, uma das iniciativas que compõem o Pacto pelo Saneamento.

\subsection{O município do Arraial do Cabo e os atuais desafios para o desenvolvimento da política local de resíduos sólidos: a fala dos sujeitos}

Como ressaltado anteriormente, com o advento da Lei $\mathrm{n}^{\mathrm{o}} 12.305 / 2010$, que instituiu a PNRS e com os Decretos $n^{\circ} 7.404 / 2010$ e $n^{\circ} 7.405 / 10$ foram criadas no país importantes instrumentos para enfrentar os problemas ambientais, sociais, econômicos e de saúde pública decorrentes do inadequado tratamento dos resíduos sólidos, entre eles os planos de resíduos sólidos, a coleta seletiva, os sistemas de logística reversa e outras ferramentas relacionadas à implantação da responsabilidade compartilhada pelo ciclo de vida dos produtos, os acordos setoriais, o incentivo à criação e ao desenvolvimento de cooperativas ou de outras formas de associação de catadores e de catadoras de materiais reutilizáveis e recicláveis, e o Sistema Nacional de Informações sobre a Gestão dos Resíduos Sólidos - SINIR.

Todavia, depois de mais de oito anos da promulgação da PNRS, e após mais de um ano da $11^{a}$ Câmara Cível condenar o município de Arraial do Cabo, com vistas à elaboração e a implantação de Política Municipal de Gerenciamento de Resíduos Sólidos, e de nove meses do Ministério Público do Estado do Rio de Janeiro requerer cumprimento de sentença, o quadro do município de Arraial do Cabo em relação ao planejamento, a avaliação, a fiscalização, a transparência e o monitoramento das ações governamentais no âmbito da gestão e do gerenciamento integrado dos resíduos sólidos permanece adverso, em contrariedade aos preceitos da PNRS, como veremos a seguir. 
Segundo $\mathrm{Sr}^{\mathrm{o}}$ V. F, ex-dirigente estadual do MNCR, o Plano Municipal de

Resíduos Sólidos nunca passou de uma aspiração de alguns setores da sociedade.

O município se apegou a um dos artigos da lei de resíduos na qual os municípios com menos de 50 mil habitantes poderiam ter dentro do Plano de Saneamento o seu Plano de Resíduos, o que a meu ver é um equívoco porque todos os municípios deveriam ter o seu Plano de Resíduos separados em função da sua complexidade. No município o Plano de Resíduos ficou dentro do Plano de Saneamento. (...). Só que o Plano de Saneamento que foi produzido pela empresa SERENCO foi muito falho. Eu, por exemplo, critiquei o Plano por diversos motivos. Primeiro porque foi um recorte e cole danado. Segundo porque não considerou as especificidades de cada município, sendo muito genérico. Terceiro que o Plano em si não foi satisfatório principalmente para os resíduos. Além disso, o Plano não passou pela Câmara, não teve audiência pública, os catadores só participaram do processo por entrevista e para piorar o Plano de Saneamento não foi publicado. O Plano Municipal de Resíduos Sólidos, que permite a avaliação da implantação e execução da política de resíduos foi proposto por diversas vezes no Conselho Municipal de Meio Ambiente e junto ao governo municipal, porém não avançou, não passou de um desejo de alguns setores da sociedade. (Sr. VF ex-dirigente estadual do MNCR, entrevista concedida em novembro de 2018).

O Sr. H. S, ex-diretor da Fundação de Meio Ambiente corroborou com a fala do ex-dirigente do MNCR.

Nem o Plano de Saneamento, nem o de Plano de Resíduos foi efetivado no município. O Plano de Saneamento foi feito, mas não tenho conhecimento da sua publicação, já o Plano de Resíduos que é mais específico não saiu do campo das ideias. Nós propusemos o Plano de Resíduos Sólidos, mas não conseguimos tocálo. Fizemos um grande diagnóstico para elaborar o projeto aprovado na FUNASA, mas o Plano de Resíduos impõem muito mais. O Plano de Resíduos é o pilar para o cumprimento da Política de Resíduos Sólidos. Nele é realizado o diagnóstico dos resíduos sólidos gerados, definindo as áreas favoráveis à disposição final ambientalmente adequada, os procedimentos operacionais para os serviços públicos de limpeza urbana e de manejo de resíduos sólidos, além das responsabilidades e os programas e as ações ambientais voltadas a coleta seletiva e a reciclagem de resíduos sólidos. No nosso município a não produção do Plano de Resíduos Sólidos deveu-se a dificuldade de articulação e integração colaborativa entre os setores governo e, sobretudo, a ausência de vontade política do poder público local. Não ter o Plano é um grande erro da gestão municipal e isso ainda trará muitos problemas para Arraial do Cabo, em especial para os catadores. (Sr. H. S, ex-diretor da Fundação de Meio Ambiente, novembro de 2018).

A fala do catador A da Cooperativa de Coleta e Reciclagem da Costa do Sol sobre a ausência do Plano Municipal de Resíduos foi extremamente crítica. Ele 
reforçou a necessidade de produzi-lo, sobretudo com a participação ativa dos catadores e catadoras de materiais recicláveis.

Não produzir o Plano Municipal de Resíduos Sólidos é um problema porque prejudica o município, o meio ambiente e os catadores que vivem da reciclagem. É o Plano que diz o que tem que ser feito, quando e como tem que ser feito. Sem ele fica muito difícil da gente ter uma direção, de saber o que é certo ou errado, de saber as responsabilidades de cada um. Nós que ficamos na ponta e que na prática tocamos a reciclagem é quem mais sentimos. Tem que dar um jeito de fazer o Plano porque com ele a nossa vida vai melhorar muito porque a lei será cumprida e o catador valorizado. Sem ele a nossa vida piora e o nosso trabalho fica prejudicado. O Plano é bom também porque mostra a nossa importância e que sem a gente a roda não gira. Como fazer reciclagem sem o catador? O Plano é isso, é o fundamento da coisa toda. Por isso muita gente não gosta do Plano de Resíduo porque se ele existir tem que gastar, tem que fazer, tem que cumprir. É o x da questão, né? Agora tem uma coisa, é para fazer o Plano de verdade e com a nossa participação porque é a gente que conhece de lixo, não adianta chegar com ele pronto, tem que ter participação do catador. Aqui no município e na Usina, tem um monte de coisa que não existiria se o Plano estivesse pronto. O governo precisa se ligar que fazer o Plano é bom para todo mundo, o governo sai ganhando, a natureza sai ganhando e catadores ganham. (Catador A da Cooperativa de Coleta e Reciclagem da Costa do Sol, entrevista concedida em novembro de 2018).

No que tange à publicização da política de resíduos, Sr. D. A informou que o município não possui uma estratégia de divulgação e apresentação de sua Política de Resíduos Sólidos, fato que consiste em outra fragilidade.

A comunicação com a sociedade deve ser constante para que a mensagem possa ser transmitida, multiplicada e praticada. (Sr. D. A, ex Secretário de Ambiente, novembro de 2018).

Para $\mathrm{Sr}^{\circ}$ H. S, uma das principais ações para efetivação da política de resíduos local seria a criação de uma estratégia de comunicação eficiente, promovendo conhecimento dos objetivos e das diretrizes da PNRS.

Não há no município de Arraial do Cabo uma cultura para orientar a população sobre a implantação de políticas públicas. É preciso se criar uma política de comunicação para que as pessoas percebam a sua responsabilidade e o seu papel diante da gestão dos resíduos. Assim haveria um envolvimento maior de toda sociedade, tanto na participação da política quanto no monitoramento, na fiscalização e na avaliação da gestão dos resíduos sólidos. (Sr. H. S, novembro, 2018). 
A catadora $X$ reforçou em sua fala a necessidade de uma política de comunicação e sinalizou para a importância do papel educativo para efetivação da política de resíduos.

A falta de conhecimento é um problema grande e que precisa ser superado com a educação e a informação. O problema é grande porque as pessoas não sabem de nada sobre o lixo, o que elas querem e tirar de perto delas porque lixo fede, lixo é feio, lixo é ruim. A primeira coisa que o povo precisa saber é que lixo não é nada disso, o lixo pode virar fonte de emprego, de renda e de sobrevivência para as pessoas. Isso é o primeiro. Depois tem que mostrar que se o lixo for separado ele chega limpo e facilita a vida do trabalhador. Tem que mostrar também que todos têm responsabilidades. E como fazer isso? É informando meu amigo, é educando o povo porque se cada um fizer a sua parte vai melhorar. (X, catadora da Cooperativa de Coleta e Reciclagem da Costa do Sol, novembro, 2018).

Conforme exposto pelos entrevistados, à inexistência de estratégia de comunicação com canais específicos de divulgação que apresente à sociedade do município a política de resíduos sólidos, consiste em um grande obstáculo para a sua adesão, tendo em vista que dificulta o conhecimento dos seus princípios, objetivos e metas, bem como da responsabilidade dos atores sociais na gestão integrada dos resíduos.

Em relação à destinação final os entrevistados apontaram para avanços, contudo não ao ponto do município executar uma destinação adequada como preconiza a PNRS.

Conseguimos por meio de convênio com a FUNASA recursos para a reforma e ampliação da Usina de Reciclagem, fizemos o prédio administrativo que deu melhores condições para os catadores, reformamos o galpão de reciclagem, construímos os galpões para compostagem e reciclagem de entulho, além de equipamentos e maquinários. Mesmo com esse avanço o município de Arraial do Cabo não conseguiu alcançar uma destinação adequada dos resíduos. Ainda não há a coleta seletiva com inclusão social dos catadores, não há a reciclagem de entulho, nem tampouco a compostagem. Além disso, o lixão foi fechado, mas algumas vezes é reaberto. A chamada Estação de Transbordo funciona de forma precária. Então a PNRS tá sendo cumprida em parte, certo? O que falta se há condições mínimas para destinação adequada dos resíduos? Falta a meu ver uma perspectiva socioambiental e integrada do problema, que entenda a dimensão ambiental, social, cultural, econômica, tecnológica e de saúde pública para a gestão dos resíduos sólidos. Falta perceber a necessidade de cooperação entre as diferentes esferas do poder público, o setor empresarial e demais segmentos da sociedade. Falta entender também que injetar recursos em políticas públicas de gestão de resíduos sólidos não é gasto, mas investimento. (Sr. H. S entrevista concedida, novembro de 2018). 
A fala do catador A da Cooperativa de Coleta e Reciclagem da Costa do Sol corroborou com a visão do ex-diretor da Fundação de Meio Ambiente.

\begin{abstract}
A gente no começo achou que a obra era papo furado como sempre foi antes, mas a verdade é que ela demorou, mas veio. Antes a gente ficava numa condição bem pior, era ruim demais. Uma coisa boa foi sair do lixão que era muito degradante, muito desgastante, era chuva, sol, uma condição de trabalho nada digna. Não estou cuspindo no prato que comi, só tô dizendo que lá era muito brabo. A gente pode reclamar de um monte de coisa como a demora no nosso repasse, no transporte e para ter a coleta seletiva, só que sobre a estrutura para fazer a reciclagem não. Fizeram o prédio administrativo, e nós agora temos um lugar decente para nos reunir, descansar, comer e tomar banho. Reformaram o galpão central, construíram mais um galpão para fazer compostagem e um para entulho, tudo com maquinário. Agora dá para a gente fazer a reciclagem porque temos condições, tem esteira, prensa, galpão que nos protege. Pode melhorar? Pode e muito. Agora só precisa ativar a compostagem, fazer a reciclagem do entulho e a coleta seletiva, se fizer isso vai ficar show de bola. (Catador A da Cooperativa de Coleta e Reciclagem da Costa do Sol, novembro de 2018).
\end{abstract}

Sobre a coleta seletiva encontramos uma mensagem uníssona de que muito se foi discutido e proposto, entretanto na prática poucas ações foram consolidadas.

Para os entrevistados houve vontade de efetivar os projetos e as ações para a coleta seletiva, tendo em vista que ela é uma importante ferramenta para reduzir o volume dos resíduos a serem direcionados aos aterros sanitários, para a melhoria da limpeza urbana, o aumento do ICMS Ecológico, a eliminação dos passivos socioambientais, o cumprimento das determinações legais e a geração de emprego e renda por meio do fomento à organização produtiva dos catadores de materiais reutilizáveis e recicláveis.

O Sr. H. S destacou que o projeto de estruturação da gestão de resíduos no município a partir de 2009, proposta pelo setor ambiental sempre teve na coleta seletiva com a participação do catador o norte, mas apesar de todos os esforços e discussões no sentido de apoiar e desenvolver políticas públicas de inclusão econômica e social dos catadores a implantação do programa de coleta seletiva no município não foi consolidada.

O ponto de partida da Política Municipal de Gerenciamento Integrado de Resíduos Sólidos Urbanos sempre foi a segregação dos resíduos conforme sua constituição ou composição. Mas nós sabíamos que implantar a coleta seletiva seria um processo difícil, de longo prazo, de baixo retorno financeiro e iria requerer investimentos, em particular na operação do sistema de coleta seletiva e no programa de educação ambiental visando à conscientização da população sobre o gerenciamento adequado dos resíduos. Tínhamos como premissa que o 
programa de coleta seletiva deveria ocorrer concomitantemente à coleta regular com a pretensão de que em longo prazo se estenderia a todo município. Neste processo os catadores da Cooperativa de Coleta e Reciclagem da Costa do Sol seriam os responsáveis pela coleta, o que contribuiria para melhoria da qualidade de vida dos catadores e consequentemente para a justiça social. Nossa ideia era que o sistema de coleta seletiva iniciasse nas instituições públicas, como setores da administração municipal e nas praças da cidade. A pretensão de iniciar este trabalho na esfera pública baseava-se na promoção da educação ambiental e da coleta seletiva nos próprios segmentos que as propunha, assim instituir políticas de consumo consciente e de reciclagem no dia a dia das instituições públicas seria uma medida imprescindível para obtenção dos resultados esperados. No que se refere ao gerenciamento de resíduos nas repartições municipais, a prefeitura instalaria lixeiras que teriam a denominação de lixo orgânico e inorgânico para serem posteriormente recolhidos pelos caminhões cedidos à Cooperativa de Coleta e Reciclagem da Costa do Sol. Nas praças municipais seriam instalados Posto de Entrega Voluntária (PEV), onde o próprio gerador se deslocaria até um container e depositaria o material reciclável segregado. O material depositado nos containeres seria recolhido conforme roteiro de coleta e encaminhado para a Estação de Triagem. Nas praias seriam instaladas lixeiras. Teríamos também o projeto piloto na Vila Industrial como experiência inicial, que iríamos acompanhar e avaliar os desdobramentos da implantação da política da coleta com mais detalhamento e rigor científico num período de 06 meses. A partir desta experiência estenderíamos a coleta seletiva por toda cidade num processo contínuo e gradual. No plano das ideias o projeto estava todo alinhado, entretanto viabilizá-lo não foi possível na prática em função de vários obstáculos, o principal com toda certeza foi que a gestão de resíduos e a coleta seletiva em particular não eram prioridades na política governamental. (Sr. H. S, novembro de 2018).

O Sr D. A. ex-secretário de Ambiente afirmou que na sua gestão a frente da Secretaria tocou algumas ações voltadas à coleta seletiva, porém estas não se consolidaram. Já em relação à coleta seletiva na gestão atual falou que não ocorre efetivamente, mas que torce para que ocorra.

Durante a gestão, buscamos muito esses objetivos, porém, não foram suficientes, pois não conseguimos sensibilizar os gestores financeiros locais para estas questões. Criamos o Fundo Municipal de Meio Ambiente, conseguimos dar um passo que foi a compra de estações de triagem para a coleta seletiva e tentamos financiar a coleta seletiva através de contratação de catadores conforme a PNRS preconiza, mas acabou tendo muita resistência política (...). Infelizmente de forma efetiva ainda não. Temos historicamente visto alguns movimentos que começaram mais não alcançaram a sustentabilidade e continuidade. Ultimamente fiquei sabendo da chegada de um veículo (caminhão) para coleta e fiquei muito satisfeito. Torço para que aconteça de fato. (Sr. D. A, novembro de 2018).

No dia 26 de novembro de 2018, uma semana após a entrevista com David Aguiar, o município iniciou o Projeto Piloto da Coleta Seletiva, que foi elaborado 
pela equipe da Diretoria de Estudos e Projetos da Fundação Municipal de Meio Ambiente, Pesquisa, Ciência e Tecnologia.

Segundo a declaração feita ao site https://www.facebook.com/fundambientepesquisacienciatecnologia/, Leonízia Melo, atual presidente Fundação Municipal de Meio Ambiente, afirmou que a gestão dos resíduos sólidos recicláveis ocorrerá de maneira integrada, envolvendo mais duas secretarias e a Cooperativa de Coleta e Reciclagem da Costa do Sol, cada órgão competente com suas atribuições de modo a colaborar para a efetividade do Programa.

Ela definiu como meta alcançar até o final do segundo semestre de 2019 todas as residências até os Distritos. Para tanto, destacou a parceria da Prefeitura Municipal de Arraial do Cabo com o INEA, por meio do projeto Coleta Seletiva de Resíduos Sólidos no Estado do Rio de Janeiro e que o município recebeu a doação de 1 caminhão tipo baú, adquirido com recursos do Fundo Estadual de Conservação Ambiental e Desenvolvimento Urbano - FECAM.

Sobre a erradicação do lixão muitos entrevistados apontaram que esta não é uma tarefa fácil, pois requer planejamento, capacidade institucional e administrativa, recursos orçamentários e financeiros, base social e anseio político de exercer uma política pública comprometida com a sustentabilidade socioambiental.

No caso do município de Arraial do Cabo, a questão do fechamento do lixão foi também apontada como uma situação controversa por um dos sujeitos pesquisados, pois apesar de ocorrer por uma determinação legal dos órgãos ambientais fiscalizadores, o processo não é feito com a seriedade necessária, visto que foi destacado que muitos resíduos ainda são depositados no local contrariando as determinações judiciais já efetivadas.

Já tô aqui nesse trabalho há muito tempo, já vi muito fecha lixão, abre lixão, fecha lixão, abre lixão. A FEEMA já fechou, o INEA já fechou, o Ministério Público já fechou, o Ministério do Trabalho já fechou, só que sempre se deu um jeito de reabrir. Agora tá mais difícil por causa da lei de resíduos, todo mundo sabe que pode dar ruim, dá merda. Mas mesmo assim, sempre tem gente jogando lixo no lixão de forma irregular. (Catador A. da Cooperativa de Coleta e Reciclagem da Costa do Sol). 
O Sr. V. F afirmou que a disposição final inadequada é um grande problema no município e que é preciso investir efetivamente no projeto de erradicação do lixão.

O município não resolveu o problema do lixão. O nosso lixão inclusive virou um lixão móvel. Fechou uma parte e abriu outra. Eu sempre fui crítico a ideia de uma Estação de Transbordo porque onde eu andei pelo Brasil isso nunca funcionou, o Transbordo sempre vira lixão, né? É sempre um paliativo das administrações que dizem que vão fazer o Transbordo para melhorar, mas nunca se apresenta um plano. A gente não consegue ter um projeto de erradicação do lixão e sem projeto não tem como conseguir fazer. Já foi proposto que o Conselho Municipal de Meio Ambiente pagasse e fizesse uma parceria com Universidades para fazer o projeto. Fui voto vencido no Conselho Municipal de Meio Ambiente porque no município se acha que se tem gente para fazer, mas não é uma coisa simples, não se tem expertise e capacidade técnica na nossa estrutura para fazer um projeto. Depois do projeto pronto é correr atrás de dinheiro para pagar erradicação do lixão. (Sr. V. F. entrevista concedida em novembro de 2018).

Para $\mathrm{Sr}^{\circ} \mathrm{H}$. S o lixão é um problema antigo do município, sobretudo, pela localização numa área de restinga. Por isso sempre foi uma preocupação central da Fundação de Meio Ambiente.

Quando elaboramos o projeto da Fundação Municipal de Meio Ambiente, Pesquisa, Ciência e Tecnologia para contribuir com a implantação de uma política pública de resíduos sólidos urbanos no município de Arraial do Cabo, tínhamos a premissa de acabar com a destruição da restinga de Massambaba pelo inadequado tratamento dos resíduos. Assim traçamos quatro objetivos centrais. Melhorar as condições econômicas, sociais e sanitárias do município e dos catadores de resíduos, eliminar os passivos socioambientais ocasionados pela gestão inoperante e inadequada dos resíduos sólidos, atendendo assim aos princípios das legislações sobre o gerenciamento de resíduos sólidos urbanos, reutilizar os materiais recicláveis (papel, vidro, plástico, metal, madeira, dentre outros), reaproveitar o material orgânico, o transformado em adubo de ótima qualidade e reciclar os resíduos da construção civil, transformando-os em produtos utilizáveis na própria construção civil, reduzindo assim a quantidade de lixo destinada ao Aterro Sanitário Regional, diminuindo os gastos na sua utilização e principalmente desativar o lixão, buscando futuramente a recuperação ambiental da área degradada e a eliminação de vetores patogênicos, minimizando os gastos com saúde pública. Avançamos em alguns desses objetivos, mas o lixão mesmo com as obras da Usina continuou funcionando até ser fechado pelo INEA. Mas hoje, em pleno 2018, se tem notícia de que ainda que o lixão recebe resíduo irregularmente, principalmente o da construção civil. Para piorar ao lado da Usina tem um pequeno vazadouro de lixo, que intitularam de Estação de Transbordo. (Sr. H. S, novembro de 2018). 
Figura 34: Área de Transbordo

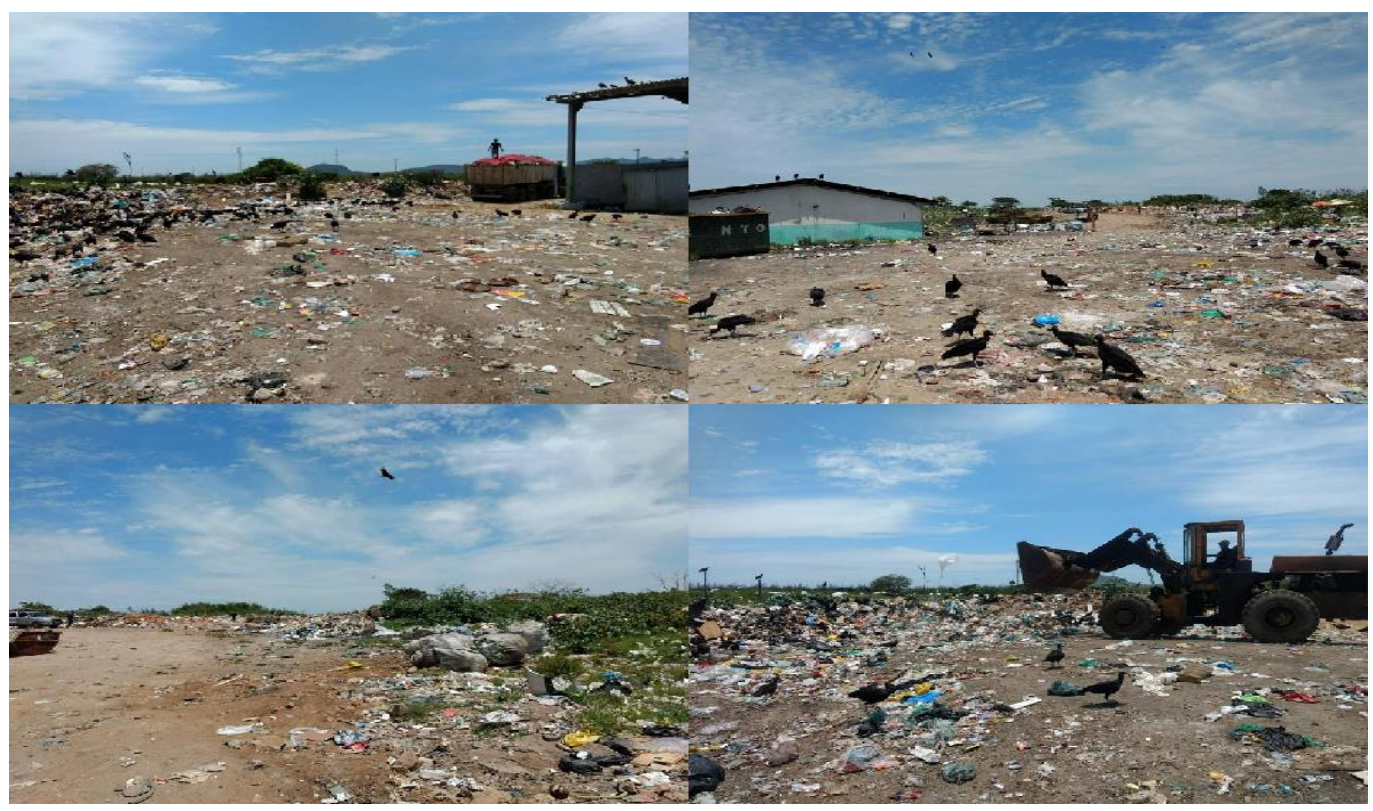

Fonte: Wanderson Jardim, novembro de 2018.

Outra fragilidade que dificulta a gestão integrada no município é a ausência da logística reversa e outras ferramentas relacionadas à implantação da responsabilidade compartilhada pelo ciclo de vida dos produtos.

Mesmo sem dar o nome de logística reversa, a catadora $\mathrm{X}$ da Cooperativa de Coleta e Reciclagem de Arraial do Cabo afirmou que esse instrumento da política não se efetivou e quem faz o serviço pelas empresas responsáveis pelo recolhimento são os catadores e a própria municipalidade. Além desse aspecto, ressaltou a seletividade na aplicação da lei.

Na lei diz que os caras que produzem as embalagens devem recolher ou contratar as cooperativas para fazer o serviço. Aqui no Cabo não tem isso não, somos nós que recolhemos ou então o município, mas não recebemos nada por isso. Isso prova que a lei vale só para alguns, para os mais fracos é pau no lombo. A lei é isso, funciona só para quem tem dinheiro. Como dizia um cabista das antigas 'para uns até o boi dá leite, para outros nem a vaca dá'. A lei é boa para os catadores, falta é fiscalizar. Os órgãos de meio ambiente vêm aqui e fecha o lixão. É nosso sustento, mas se é a lei é a lei. Agora se vale para Chico vale para Francisco, então tem que funcionar também para esses caras que não fazem nada, ganham dinheiro à custa do catador e do município e ainda não cumprem a lei. $\mathrm{O}$ tubarão tem que cumprir a lei igual à sardinha, senão, não dá. (Catadora $X$ da Cooperativa da Costa do Sol, novembro de 2018).

Segundo a Catadora G. C, coordenadora do Movimento Eu Sou Catador MESC a expectativa em torno da logística reversa e dos acordos setoriais para a melhoria das condições dos catadores de materiais recicláveis foi frustrada: 
Quando saiu a Política Nacional de Resíduos Sólidos a logística reversa e o acordo setorial de embalagem eram as esperanças de que aquecesse o mercado e fosse $\mathrm{o}$ aporte financeiro para investir na categoria dos catadores e nos equipamentos para melhorar a coleta em si. O que o MESC entendeu é que não existe investimento direto nas cooperativas para a logística reversa. Existe um investimento muito pequeno, em projetos pontuais para justificar que estão cumprindo o acordo. Se pagassem hoje a gente teria uma categoria mais forte, mais organizada, as cooperativas já estão preparadas para fazer o serviço de limpeza urbana e principalmente o serviço de reciclagem. O Plano Nacional de Resíduos Sólidos diz que pra fazer a logística reversa tem que preferencialmente, contratar as cooperativas de catadores, a gente tá querendo mudar o nome para obrigatoriamente. Isso faz com que a empresas reconheçam que as cooperativas existem que esses profissionais existem e que ela tem que de alguma forma fazer parcerias com essas cooperativas. Eu sei que não há controle dessas empresas, o que eu sei é que $90 \%$ disso é retirado por catador e eles não pagam por esse serviço. Os investimentos são pequenos, eles saem na vantagem e com a fama de tá preservando o meio ambiente. Por isso que a gente tá defendendo crédito de logística reversa. Não dá também para toda hora jogar para o município a culpa porque vêm lá de cima, as empresas tem que arcar com a sua responsabilidade legal, eles são os grandes poluidores e nós catadores os despoluidores e temos que receber por isso. Tem que ter uma responsabilidade compartilhada. (Catadora G. C coordenadora do MESC, entrevista concedida em julho de 2018).

Ao perguntar aos catadores e catadoras se eles (as) se sentiam incluídos na gestão de resíduos do município a resposta foi que sim, contudo com variações interessantes no argumento, conforme veremos a seguir.

Eu me sinto incluído porque tô trabalhando, tô ganhando um dinheiro honestamente e excluído é que não trabalha. (Catador $\mathrm{Z}$ da Cooperativa da Costa do Sol, novembro de 2018).

Incluído a gente é, mas é uma inclusão meio esquisita, sem muita vantagem. A gente trabalha muito e que ganha com isso são os outros. Sem falar nas condições de trabalho que não são as melhores. (Catador A da Cooperativa da Costa do Sol, novembro de 2018).

A gente trabalha enquanto tem muita gente desempregada, então estamos incluídos, só que poderia ser uma inclusão mais digna, que a gente tivesse uma remuneração melhor e melhores condições para trabalhar. (Catadora $\mathrm{X}$ da Cooperativa da Costa do Sol, novembro de 2018).

Nessa pesquisa em que nos debruçamos em investigar a implantação tardia da Política Nacional de Resíduos Sólidos (2010), mais precisamente as suas fragilidades, limites e possibilidades, tomando como fio condutor de reflexão o planejamento, a avaliação, a fiscalização, a transparência e o monitoramento das 
ações governamentais no que tange à gestão e ao gerenciamento de resíduos sólidos no município do Arraial do Cabo, no Estado do Rio de Janeiro, concluímos que essa política contribui para uma inclusão social precária dos catadores e das catadoras de materiais recicláveis na gestão de resíduos, reforçando os processos de vulnerabilidades e laços de dependência junto ao poder público municipal. 


\section{Considerações Finais}

A Política Nacional de Resíduos Sólidos, partindo de uma visão sistêmica que considera as variáveis ambiental, social, cultural, econômica, tecnológica e de saúde pública, introduziu inovações paradigmáticas na gestão e no gerenciamento dos resíduos, entre elas: os princípios da prevenção e precaução; a ideia de que a discussão dos resíduos deve se iniciar pela não geração, passando pela redução, reaproveitamento, reciclagem, tratamento até a disposição final ambientalmente adequada dos rejeitos; a noção de que o resíduo sólido reciclável é um bem econômico e de valor social, gerador de trabalho e renda e promotor de cidadania, e que a sociedade civil tem o direito à informação e ao controle social.

Além desses pontos, instituiu a responsabilidade compartilhada pelo ciclo de vida dos produtos, a coleta seletiva e a logística reversa e reconheceu a importância dos catadores e das catadoras de materiais recicláveis como sujeitos sociais corresponsáveis na organização e na execução da gestão integrada de resíduos sólidos.

Com a finalidade de integrar e articular as ações do Governo Federal voltadas ao apoio e ao fomento à organização produtiva dos catadores e das catadoras de materiais reutilizáveis e recicláveis e à ampliação das oportunidades de inclusão social e econômica e à expansão da coleta seletiva de resíduos sólidos, da reutilização e da reciclagem por meio da atuação desse segmento foi instituído o Programa Pró-Catador.

Apesar dessa política representar um profundo avanço no sentido de buscar maximizar benefícios econômicos, ambientais e sociais, por meio de uma iniciativa que privilegia a inclusão social e a geração de trabalho para a população de baixa renda, como destacaram Demajorovic et. al. (2007), ao analisarem um conjunto de programas de gestão compartilhada, baseada na integração entre o poder público e as organizações de catadores e de catadoras na gestão dos programas de coleta seletiva de materiais recicláveis, elas não se tornaram sustentáveis na medida em que encontraram um conjunto fragilidades, vulnerabilidades e desafios.

O quadro apresentado sobre a gestão e o gerenciamento de resíduos no município do Arraial do Cabo é ilustrativo neste sentido, pois após oito anos de aprovação da PNRS há uma série de fragilidades a serem superadas para que o 
município alcance uma gestão integrada dos resíduos sólidos e, consequentemente, contribua para a justiça ambiental e para a redução dos processos de vulnerabilidade, aos quais os catadores e catadoras de materiais recicláveis são submetidos.

As fragilidades encontradas em Arraial do Cabo, assim como em muitos outros municípios brasileiros são obstáculos que impossibilitam a democrática inclusão social dos catadores e catadoras de materiais recicláveis no processo de gestão e contribuem com os mecanismos de injustiças ambientais, reforçando os laços de dependência desses sujeitos junto à administração pública.

Essas fragilidades devem ser analisadas em suas particularidades, mas sem perder de vista que uma parte considerável delas está conectada ao descumprimento de atribuições impostas pela PNRS à União, aos Estados, ao setor empresarial e à sociedade.

Em nível de esclarecimento, apoiando-nos na auditoria desenvolvida pelo CGU para avaliação da atuação do Governo Federal no cumprimento da meta de eliminação dos lixões e consequente disposição ambientalmente adequada dos resíduos (BRASIL, 2016b), podemos citar algumas fragilidades em esfera nacional que prejudicam o cumprimento das determinações da PNRS, entre elas: a baixa execução orçamentária e financeira das ações destinadas à implantação da PNRS, a descontinuidade do aporte de recursos aos entes federados, a baixa efetividade nas capacitações realizadas pelo Ministério do Meio Ambiente MMA, a atuação insuficiente do Comitê Interministerial da PNRS no apoio e na estruturação da política, as falhas no Sistema Nacional de Resíduos Sólidos SINIR e a não publicação do Plano Nacional de Resíduos Sólidos, o principal instrumento da PNRS.

De modo algum essas fragilidades em âmbito nacional retiram a responsabilidade do município na aplicação da PNRS, porém servem para demonstrar que a gestão só ocorrerá de forma compartilhada quando todos os sujeitos sociais participantes do processo de gestão assumir as suas atribuições.

Ao analisarmos sob a ótica da governança, a forma pela qual fora institucionalizada e normatizada a Política de Resíduos Sólidos no município de Arraial do Cabo, verificamos que a ausência do Plano Municipal de Resíduos, compromete a implantação da política, tendo em vista que nesse instrumento são definidos as prioridades, as diretrizes, as estratégias, as metas, os programas, as 
ações, as responsabilidades e os indicadores de sustentabilidade na gestão e no gerenciamento dos resíduos sólidos.

Essa fragilidade no âmbito municipal se amplia no cenário na qual a União não publica o Plano Nacional de Resíduos Sólidos porque se perde o referencial jurídico para a avaliação, o monitoramento e a fiscalização da política, bem como o controle social em relação à ação estatal, visto que não estão delineadas as ações necessárias a serem tomadas pelas três esferas de governo em relação às diretrizes, os objetivos e as metas da PNRS.

Com recursos obtidos na FUNASA, o município de Arraial do Cabo investiu na reforma e na ampliação da Usina de Reciclagem, construindo uma sede administrativa para a Cooperativa de Coleta e Reciclagem da Costa do Sol, composta por uma sala de reuniões, vestiários masculino e feminino, copa, cozinha e um novo refeitório em substituição à sede anterior que era pequena, pouco arejada e insalubre. Foi possível também melhorar a estrutura operacional com a reforma e a construção dos galpões e a aquisição de maquinários mais ergonômicos, propiciando condições mais favoráveis de trabalho para esses profissionais. Todavia, o município apesar do aporte financeiro não conseguiu implantar um sistema de destinação final adequado, entendido como a destinação de resíduos que inclui a reutilização, a reciclagem, a compostagem, a recuperação e o aproveitamento energético ou outras destinações admitidas pelos órgãos competentes.

Nesse sentido, as nossas percepções coadunam com a de Besen (2011), que em sua tese de doutorado intitulada "Coleta seletiva com inclusão de catadores: construção participativa de indicadores e índices de sustentabilidade" constatou que, em 2010, mesmo diante dos investimentos do governo federal em projetos para a implantação da coleta seletiva e o fortalecimento das organizações de catadores e de catadoras de materiais recicláveis, as administrações municipais enfrentavam dificuldades técnicas, administrativas e financeiras para prestar o serviço de coleta seletiva de forma universalizada e eficiente, particularmente por meio das organizações de catadores e catadoras de materiais recicláveis.

$\mathrm{Na}$ PNRS, em seu Art. 54 ${ }^{\circ}$, ficou estabelecido que a disposição final ambientalmente adequada, que é distribuição ordenada de rejeitos em aterros, quando esgotadas todas as possibilidades de tratamento e recuperação por processos tecnológicos disponíveis e economicamente viáveis, observando 
normas operacionais específicas de modo a evitar danos ou riscos à saúde pública e à segurança e a minimizar os impactos ambientais adversos, deveria estar implantada até o dia 02 de agosto de 2014. Entretanto, após mais de quatro anos do prazo estabelecido para a erradicação dos lixões no país e de oito anos após promulgação da lei, os Municípios enfrentam problemas para a disposição adequada.

Em Arraial do Cabo a situação não é diferente. Apesar da reforma e ampliação da Usina de Reciclagem e do contrato com o Aterro Sanitário de São Pedro da Aldeia, a disposição final adequada dos resíduos não ocorre conforme determina a PRNS. No dia 08 de fevereiro de 2018, uma equipe da Coordenadoria Integrada de Combate a Crimes Ambientais - CICCA da Secretaria Estadual do Ambiente fez uma operação interditando o lixão de Arraial do Cabo, em função do despejo irregular de "lixo" em uma área de proteção ambiental. Nessa operação, os técnicos do INEA e os policiais flagraram um caminhão a serviço da Prefeitura de Arraial do Cabo despejando resíduos da construção civil e outros dois carregados de lixo e uma escavadeira hidráulica fazendo o manejo dos resíduos nessa área, sem nenhuma licença.

Segundo os técnicos do INEA essa ação irregular tem como consequências agravos à saúde pública, danos ambientais como o aumento das emissões de gases de efeito estufa, a poluição do solo e das águas superficiais e subterrâneas pelo chorume produzido pela decomposição dos resíduos, aumento de incêndios causados pelos gases, ocasionando impactos nos ecossistemas e na biodiversidade e a geração de odores desagradáveis, insegurança aérea, pelo risco de graves acidentes aéreos e danos sociais pelas condições de vulnerabilidades na qual os catadores e as catadoras de materiais recicláveis são submetidos.

O que verificamos por meio da revisão documental - Ação Civil Pública - e pelas entrevistas com os sujeitos sociais envolvidos na gestão dos resíduos é que a municipalidade mesmo após o prazo definido pela PNRS só fechou oficialmente o lixão após determinação dos órgãos fiscalizadores.

Mas o que ocorreu com os catadores e as catadoras que atuavam no lixão de Arraial do Cabo?

Bastos (2015), em seu estudo, apontou para os estados de vulnerabilidade social que os catadores e as catadoras de materiais recicláveis do antigo lixão de Gramacho se encontravam submetidos. Ela ressaltou que o fechamento dos lixões, 
sem a incorporação efetiva desses profissionais no sistema de gestão de resíduos de forma justa e financeiramente sustentável pioraria as já precárias condições de saúde, segurança e trabalho.

Em Arraial do Cabo, com o fechamento do lixão ao contrário do que aconteceu com muitos municípios no Brasil, os catadores e as catadoras da Cooperativa de Coleta e Reciclagem da Costa do Sol permaneceram incorporados ao processo de gestão de resíduos, mesmo que de forma subalterna, precarizada e vulnerável, conforme nos sinaliza a criação da Estação de Transbordo sem nenhuma preparação técnica, que acabou por instituir como um pequeno vazadouro de resíduos ao lado da Usina de Reciclagem.

É importante frisar que a categoria vulnerabilidade foi entendida nesta pesquisa como um processo de proteção desigual do Estado, que imprime aos despossuídos de poder político e econômico e com menos potencial de se fazer ouvir na esfera pública riscos ambientais desproporcionais e não como vinculada às suscetibilidades do sujeito social aos agravos ou à sua incapacidade de defesa diante desses.

Sendo assim, nossa perspectiva se aproxima da proposta de Acselrad (2006), que abordou as condições de vulnerabilidade como uma questão de direitos humanos, vinculando-as às suas raízes sociais mais profundas, estimulando e potencializando a mobilização dos sujeitos sociais para a transformação destas condições e no caso específico da Política de Resíduos Sólidos do município de Arraial do Cabo, os catadores e catadoras de materiais recicláveis.

É imprescindível destacar também que não consideramos na análise os catadores e catadoras de materiais recicláveis como excluídos, e sim como vítimas de processos sociais, políticos e econômicos excludentes, que promovem formas marginais, deficientes, instáveis e precárias de inclusão, negligenciando assim os seus direitos dos cidadãos.

Nesse sentido, podemos argumentar que as melhorias provenientes da PNRS não conduziram à efetiva inclusão social dos catadores e catadoras de materiais recicláveis do município porque o modus operandi da política de resíduos foi centrada na lógica do mercado, que não permite ver a sustentabilidade ambiental conectada à construção da cidadania e a formas de atuação 
democráticas e promotoras da justiça ambiental. Sendo assim, consolidou-se uma inclusão precária dos catadores e das catadoras de materiais recicláveis.

Em nossa visão, essas fragilidades são decorrentes da adoção pelo poder público municipal de uma perspectiva que não considera as dimensões política, econômica, social e cultural no que tange à gestão e ao gerenciamento dos resíduos sólidos e que não valoriza o direito à cidadania, à justiça ambiental e à proteção igualitária do Estado.

Portanto, é uma política de resíduos que não problematiza o modelo de desenvolvimento insustentável, nem as precárias condições de trabalho, os riscos ambientais desproporcionais e os processos de vulnerabilidade aos quais esse segmento, despossuído de poder político e econômico e com menos potencial de se fazer ouvir na esfera pública, está submetido.

Coadunamos com Acselrad et al. (2009) quando apontam que para a superação deste quadro de injustiça social e ambiental seria necessária a alteração do modo de distribuição desigual de poder sobre os recursos ambientais e a retirada da capacidade dos poderosos de transferir os custos ambientais do desenvolvimento para os mais despossuídos. Assim, faz-se necessário uma equidade na aplicação da política de resíduos sólidos e uma regulação efetiva sobre os agentes econômicos causadores dos riscos ambientais para a democratização dos processos decisórios com plena participação dos catadores e catadoras de materiais recicláveis no processo de gestão e de gerenciamento dos resíduos no município.

Com essa tese doutorado esperamos ter contribuído para o debate acadêmico e político a respeito do processo de instituição da política de resíduos sólidos no Brasil, mostrando as suas fragilidades, contradições, limites e possibilidades, particularmente para a democrática inclusão social dos catadores e das catadoras de materiais recicláveis na gestão de resíduos. Entretanto, ressaltamos que pretendemos em trabalhos futuros preencher algumas lacunas em torno das questões levantadas na tese. 


\section{Referências Bibliográficas}

ABNT - Associação Brasileira de Normas Técnicas. NBR 1004 - Resíduos Sólidos - Classificação. Rio de Janeiro, 1987.

ALBUQUERQUE. A. C. C. O socioambientalismo na perspectiva da sociedade civil latino americana: uma análise no âmbito das conferências das Nações Unidas. Tese (Doutorado em Ambiente e Sociedade) - Instituto de Filosofia e Ciências Humanas, Universidade Estadual de Campinas (UNICAMP): Campinas - SP, 2008.

ABRELPE. Panorama dos Resíduos Sólidos no Brasil. São Paulo: ABRELPE, 2016.

ABREU, M. F. Coleta seletiva com inclusão social: municípios, empresa, instituições, condomínios e escolas. Belo Horizonte: CREA-MG, 2008.

Do lixo à cidadania. Estratégias para ação. Brasília: Caixa Econômica Federal, 2002.

ACSELRAD, H. Vulnerabilidade social, conflito ambiental e regulação urbana. O Social em Questão, v. XVIII, p. 57-68, 2015.

Disputas cognitivas e exercício da capacidade crítica: o caso dos conflitos ambientais no Brasil. Sociologias (UFRGS. Impresso), v. 15, p. 84-105, 2014.

A crítica do 'ambiente' e o ambiente da crítica. Antropolítica: Revista Contemporânea de Antropologia, v. -, p. 27-47, 2014.

Liberalização da economia e flexibilização das leis: o meio ambiente entre o mercado e a justiça. Revista de Educação, Ciências e Matemática, v. 3, p. 62-68, 2013.

O Conhecimento do ambiente e o ambiente do conhecimento? anotações sobre a conjuntura do debate sobre vulnerabilidade. Revista em Pauta, v. 11, p. 115-129, 2013.

Cidade? Espaço público? A economia política do consumismo nas e das cidades. Revista da Universidade Federal de Minas Gerais, v. 20, p. 235-247, 2013.

Ambientalização das lutas sociais? O caso do movimento de justiça ambiental. Estudos Avançados (USP. Impresso), v. 24, p. 103-120, 2010.

.; MELLO, C. C. A.; BEZERRA, G. N. O que é Justiça Ambiental. Rio de Janeiro: Garamond, 2009. 
Vulnerabilidade ambiental, processos e relações. 2006. In: II Encontro Nacional de Produtores e Usuários de Informações Sociais, Econômicas e Territoriais. Rio de Janeiro. Comunicação. Rio de Janeiro: Instituto Brasileiro de Geografia e Estatística (IBGE), 2006.

Justiça Ambiental e Construção Social do Risco. Desenvolvimento e Meio Ambiente, Ed. UFPR, Curitiba, v. 5, p. 49-60, 2002.

HERCULANO, S.; PÁDUA, J. A. Justiça ambiental e cidadania. Rio de Janeiro: Relume Dumará, 2004.

Justiça Ambiental: novas articulações entre meio ambiente e democracia.

In: IBASE/CUT-RJ/IPPUR-UFRJ, Movimento Sindical e Defesa do Meio Ambiente - o debate internacional, série Sindicalismo e Justiça Ambiental, v.3, Rio de Janeiro, 2000.

Justiça Ambiental (local e global) In. CAVALCANTI, Clóvis (Org.). Meio Ambiente, Desenvolvimento Sustentável e Políticas Públicas. São Paulo: Cortez, 1999.

. Justiça ambiental e distribuição ecológica de conflitos. In: FERREIRA, Leila da Costa (Org.). A sociologia no horizonte do século XXI. São Paulo: Bontempo Editorial, 1997.

AGENDA 21. CONFERÊNCIA DAS NAÇÕES UNIDAS SOBRE MEIO AMBIENTE E DESENVOLVIMENTO. A Agenda 21. Brasília: Senado Federal, Subsecretaria de Edições Técnicas, 1996.

AIZEN, M.; PECHMANN, R. M. Memória da limpeza urbana do Rio de Janeiro. Rio de Janeiro: Coopin, Comlurb, 1985.

ALENCAR, B. S. Emergência de Novos Atores no Desenvolvimento Sustentável: A Contribuição dos Catadores de Materiais Recicláveis no Brasil. Tese (Doutorado em Desenvolvimento Urbano), Programa de Pós Graduação em Desenvolvimento Urbano, Universidade Federal de Pernambuco. Pernambuco, 2008.

ALMEIDA, É. T. V. A disputa pelo lixo e a resistência dos catadores em contextos de segregação socioespacial. Revista Brasileira de Planejamento e Desenvolvimento, v. 6, p. 215-233, 2017.

; ALVES, P. S. A.; CORDEIRO, F. A. Desmercantilizando a Reciclagem: o protagonismo político do Movimento Nacional dos Catadores de Materiais Recicláveis. Petróleo, Royalties e Região, v. 51, p. 15-25, 2016.

.; et al. Protagonismo e esfera pública em campos dos goytacazes: a trajetória recente dos catadores do lixão da Codin. In: Catadores de Materiais Recicláveis: um encontro nacional. Rio de Janeiro: IPEA, 2016. 
De catadores de lixo a catadores de material reciclável - o que muda com a Política de Resíduos Sólidos? Um diagnóstico da trajetória de trabalho dos catadores de material reciclável e do seu protagonismo a partir do fechamento do lixão da Codin em Campos dos Goytacazes/RJ. Relatório Final. Campos dos Goytacazes: UFF, 2014.

AlMEIDA, L. A. A formulação da Política Nacional de Resíduos Sólidos: uma análise orientada pela complexidade. Tese (Doutorado Administração). Faculdade de Economia, Administração e Contabilidade, Universidade Federal de Brasília, 2016.

ARAÚJO, M. G.; VIEIRA, A. O. 2017. A economia circular pode ser solidária. In: Política Nacional de Resíduos Sólidos: implementação e monitoramento de resíduos urbanos. São Paulo: IEE USP: OPNRS, 2017.

ARAÚJO, S. M. V. G. Política Ambiental no Brasil no Período 1992-2012: Um Estudo Comparado das Agendas Verde e Marrom. Tese (Doutorado em Ciência Política) - Universidade de Brasília, 2013.

ARRAIAL DO CABO. Lei 1.653, de 30 de março de 2010. Institui a Política Municipal de Resíduos Sólidos e dá outras providências.

ARRAIAL DO CABO. Lei $\mathrm{n}^{\circ} 1.262$, de 03 de setembro de 2002. Institui o Conselho de Meio Ambiente, 2002.

. Lei $\mathrm{n}^{\circ} 1.263$, de 03 de setembro de 2002. Institui a Fundação Municipal de Meio Ambiente.

Lei n. ${ }^{\circ}$ 602, de 23 de abril de 1992. Dispõe sobre o Plano Diretor de Arraial do Cabo.

Lei Orgânica Municipal de Arraial do Cabo, de 05 de abril de 1990.

BAEDER, A. M. Educação ambiental e mobilização social: formação de catadores na Grande São Paulo. 2009. Tese (Doutorado) - Faculdade de Educação da Universidade de São Paulo, São Paulo, 2009.

BARBIERI, E. B. Cabo Frio e Iguaba Grande, dois microclimas distintos a um curto intervalo espacial. Restingas: origem, estrutura, processos. Niterói, CEUFF, p. 3-13, 1984.

BASTOS, V. P. O encerramento do lixão de Gramacho e os desafios dos catadores na busca da prática sustentável. Debates Sociais, v. 73-74, p. 274, 2015.

O fim do lixão de Gramacho: além do risco ambiental. O Social em Questão, v. 33, p. 265-287, 2015.

Catador: profissão: um estudo do processo de construção identitária do catador de lixo ao profissional catador. Jardim Gramacho, de 1996 aos 
dias atuais. Tese de Doutorado em Serviço Social, Pontifícia Universidade Católica do Rio de Janeiro, 2008.

BENCHIMOL, J. L. Pereira Passos: um Haussmann tropical: A renovação urbana da cidade do Rio de Janeiro no início do século XX. Rio de Janeiro: Secretaria Municipal de Cultura, Turismo e Esportes, Departamento de Documentação e Informação Cultural, 1990.

BERGAMINI, R. Perfil das Despesas da União - Fonte MF: de Janeiro de 2003 até Agosto de 2010. Disponível em: Acesso em: 19 nov. 2010.

BESEN, G. R.; FREITAS, L.; JACOBI. P. Política Nacional de Resíduos Sólidos: implementação e monitoramento de resíduos sólidos. São Paulo: IEE USP, OPNRS, 2017.

Acordo Setorial de Embalagens Pós-Consumo no Brasil: consulta pública e remuneração e catadores de materiais recicláveis. In: Política Nacional de Resíduos Sólidos: implementação e monitoramento de resíduos sólidos. São Paulo: IEE USP, OPNRS, 2017.

Coleta seletiva com inclusão de catadores: construção participativa de indicadores e índices de sustentabilidade. São Paulo. Tese de Doutorado em Saúde Pública: Universidade de São Paulo, 2011.

BRASIL. Lei Ordinária no 12.690, de 19 de julho de 2012. Dispõe sobre a organização e o funcionamento das Cooperativas de Trabalho. Brasília, 20 jul. 2012.

Decreto $\mathrm{n}^{\circ}$ 7.404, de 23 de dezembro de 2010. Institui a Política Nacional de Resíduos Sólidos, cria o Comitê Interministerial da Política Nacional de Resíduos Sólidos e o Comitê Orientador para a Implantação dos Sistemas de Logística Reversa, e dá outras providências, Brasília, 2010 b.

Decreto $^{\circ} 7.405$, de 23 de dezembro de 2010. Institui o Programa PróCatador, denomina Comitê Interministerial para Inclusão Social e Econômica dos Catadores de Materiais Reutilizáveis e Recicláveis, Brasília, 2010c.

Lei $\mathrm{n}^{\mathrm{o}}$ 12.305/2010. Dispõe sobre a Política Nacional de Resíduos Sólidos, Brasília, 2010a.

Lei $\mathrm{n}^{\circ} 11.445$, de 05 de janeiro de 2007. Institui as Diretrizes Nacionais para o Saneamento Básico, Brasília, 2007.

Decreto $\mathrm{n}^{\circ}$ 5.940, 25 de outubro de 2006. Institui a separação dos resíduos recicláveis descartados pelos órgãos e entidades da administração pública federal direta e indireta, na fonte geradora, e a sua destinação às associações e cooperativas dos catadores de materiais recicláveis, Brasília, 2006. 
Lei $\mathrm{n}^{\circ}$ 3.325/1999. Institui a Política Estadual de Educação

Ambiental, cria o Programa estadual de Educação Ambiental e complementa a Lei Federal no 9.795/1999 no âmbito do Estado do Rio de Janeiro, Brasília, 1999.

. Constituição (1988) Constituição da República Federativa do Brasil. 40 ed. São Paulo: Saraiva, 2007.

. Lei $n^{\circ}$ 6.938/1981. Dispõe sobre a Política Nacional do Meio Ambiente, seus fins e mecanismos de formulação e aplicação, e dá outras providências, Brasília, 1981.

Lei $\mathrm{n}^{\circ}$ 5.764/1971. Define a Política Nacional de Cooperativismo, institui o regime jurídico das sociedades cooperativas, e dá outras providências, Brasília, 1971.

BRINGHENTI, J. R. Coleta seletiva de resíduos sólidos urbanos: aspectos operacionais e da participação da população. Tese (Doutorado) - Faculdade de Saúde Pública, Universidade de São Paulo, São Paulo, 2004.

BUDA, J. F. Política Nacional de Resíduos Sólidos: efeito nas condições e meio ambiente de trabalho das cooperativas de catadores cadastradas no município de São Paulo. Tese (Doutorado em Engenharia Civil). Faculdade de Engenharia Civil, Arquitetura e Urbanismo, Universidade Estadual de Campinas, Campinas, 2014.

BURSZTIN, M. (org.). No meio da rua: nômades, excluídos e viradores. Rio de Janeiro: Gramond, 2000.

CALDERONI, S. Os bilhões perdidos no lixo. São Paulo, Humanitas, $2^{\text {a }}$ ed., 1998.

CANDOTTI, E. Reflexões e retrações de uma Eco. Estudos Avançados [online]. São Paulo, v. 6, $\mathrm{n}^{\circ}$. 15, Agosto de 1992. Disponível em: http://www.scielo.br/scielo.php?script=sci_arttext\&pid=S0103014199200020000 9\&lng=em\&nrm=isso. Acesso em: 11 de setembro de 2011.

CARNEIRO, E. J. A oligarquização da "política ambiental" mineira. In: ZHOURI, A.; LASCHEFSKI, K. and PEREIRA, D. B. (org.), A insustentável leveza da política ambiental: desenvolvimento e conflitos socioambientais. Belo Horizonte: Autêntica, 2005.

CASTEL, R. A Metamorfose da Questão Social. Petrópolis, Editora Vozes, 1998.

CEMPRE. Lixo Municipal: Manual de Gerenciamento Integrado. São Paulo: Compromisso Empresarial Para Reciclagem, 2018.

Guia de Coleta Seletiva. São Paulo: Compromisso Empresarial Para Reciclagem, 1999. 
/ITP. "Lixo Municipal: Manual de Gerenciamento Integrado". São Paulo: Compromisso Empresarial Para Reciclagem, 1995.

CGU. CONTROLADORIA GERAL DA UNIÃO. Relatório no 201602951. Avaliação dos Resultados da Gestão na Secretaria de Recursos Hídricos e Qualidade Ambiental, do Ministério do Meio Ambiente e na Secretaria Nacional de Saneamento Ambiental- SNSA do Ministério das Cidades. Brasília - DF, 2016.

CHERFEM, C. O. Relações de gênero e raça em uma cooperativa de resíduos sólidos: desafios de um setor. In: Catadores de Materiais Recicláveis: um encontro nacional. Rio de Janeiro: IPEA, 2016.

CMMAD - Comissão Mundial sobre o Meio Ambiente e Desenvolvimento. Relatório Nosso Futuro Comum. Rio de Janeiro: Fundação Getúlio Vargas, 1991.

CNM - Confederação Nacional dos Municípios. Política Nacional de Resíduos Sólidos: obrigações dos entes federados, setor empresarial setor e sociedade. 2 ed. Brasília: CNM, 2015a.

CNM, 2015b.

“Estudo Técnico - Gestão Municipal de Resíduos Sólidos", Brasília:

CNMP - Conselho Nacional do Ministério Público. Encerramento dos lixões e a inclusão social e produtiva das catadoras e catadores de materiais recicláveis - guia de atuação ministerial. Brasília, 2014. Disponível em: <http://www.cnmp.gov.br/portal/images/noticias/Encontro_Catadores_v_WEB.pd f>.

COSTA, C. M.; PATO, C. A constituição de catadores de material reciclável: a identidade estigmatizada pela exclusão e a construção da emancipação como forma de transcendência. In: Catadores de Materiais Recicláveis: um encontro nacional. Rio de Janeiro: IPEA, 2016.

CÚPULA MUNDIAL SOBRE DESENVOLVIMENTO SUSTENTÁVEL. Declaração de Joanesburgo e Plano de Implementação. Brasília: Ministério do Meio Ambiente, 2003.

COSTA, T. C. "Pequena História da Limpeza Pública na Cidade de Porto Alegre". Porto Alegre: DMLU, 1983.

D`AlmeIDA, M. L. O.; VILHENA A. Lixo Municipal: Manual de Gerenciamento Integrado, 2 ed. - São Paulo, SP: IPT / CEMPRE - (Publicação IPT 2622), 2000.

DECLARAÇÃO FINAL DA CONFERÊNCIA DAS NAÇÕES UNIDAS SOBRE DESENVOLVIMENTO SUSTENTÁVEL - RIO+20: O FUTURO QUE QUEREMOS. Organização das Nações Unidas (ONU). Resolução adotada pela Assembleia-Geral em 27 julho de 2012 - Resolução 66/288. Versão traduzida e 
revisada por Júlia Crochemore Restrepo e Daniel José da Silva. Universidade Federal de Santa Catarina. Disponível em: 〈http://migre.me/hmfHN〉. Acesso em: 9 jan. 2014.

DEMAJOROVIC, J.; MASSOTI, B. Acordo setorial de embalagem: avaliação a luz da responsabilidade estendida do produtor. In: RAE Eletrônica (Online), v. 57, p. 470-482, 2017. Disponível em: http://dx.doi.org/10.1590/s0034759020170505 .

; BESEN, G. R. Gestão compartilhada de resíduos sólidos: avanços e desafios para a sustentabilidade. In: XXXI ENANPAD 2007, 2007, Rio de Janeiro. XXXI ENAPAD 2007, 2007.

Meio ambiente e resíduos sólidos: perspectivas e limites na cidade de Viena e lições para São Paulo. Dissertação (Mestrado em Administração Pública). Pós Graduação da EAESP/FGV, São Paulo, 1994.

DIAS, S. M. Trajetórias e memórias dos Fóruns Lixo e Cidadania no Brasil: experimentos singulares de justiça social e governança participativa. Belo Horizonte. Tese (Doutorado em Ciência Política) - Faculdade de Filosofia e Ciências Humanas, Universidade Federal de Minas Gerais, 2009.

DIAS, G. F. Educação Ambiental: Princípios e Práticas. São Paulo: Editora Gaia, 2000.

DESLANDES, S. F. A Construção do Projeto de Pesquisa. In: Pesquisa social: teoria, método e criatividade. Petrópolis: Vozes, 1994.

DUPUY, J. P. Introdução à Crítica da Ecologia Política. Rio de Janeiro: Civilização Brasileira, 1980.

EIGENHEER, E. M.; FERREIRA, J. A. Três décadas de Coleta Seletiva em São Francisco (Niterói/RJ): lições e perspectivas. Engenharia Sanitária e Ambiental (Online) JCR, v. 20, p. 677-684, 2015.

A história do lixo - a limpeza urbana através dos tempos. Porto Alegre: Pallotti, 2009.

Lixo, Vanitas e Mortes: considerações de um observador de resíduos. Tese de Doutorado em Educação. UFF/RJ, 2003.

ESCOREL, S. Conceitualizando e contextualizando a exclusão social. Série Temas Codeplan, Brasília, v. 2, p. 13-29, 1998.

FERRARI, A. H. De Estocolmo, 1972 a Rio+20: o discurso ambiental e as orientações para a educação ambiental nas recomendações internacionais. Tese (Doutorado em Educação Escolar) - Faculdade de Ciências e Letras, Universidade Estadual Paulista "Júlio Mesquita Filho" (UNESP): Araraquara SP, 2014. 
FOLADORI, G. Limites do Desenvolvimento Sustentável. Campinas: Unicamp, 2001.

FREITAS, L.; BESEN, G. R.; JACOBI. Panorama da implementação da Política Nacional de Resíduos Sólidos: resíduos urbanos. In: Política Nacional de Resíduos Sólidos: implementação e monitoramento de resíduos urbanos. São Paulo: IEE USP: OPNRS, 2017.

FUNDAÇÃO ESTADUAL DE ENGENHARIA DO AMBIENTE - FEEMA. Perfil Ambiental do Município de Arraial do Cabo. Rio de Janeiro: FEEMA, 1988.

FURTADO, C. O mito do desenvolvimento econômico. Rio de Janeiro: Paz e Terra, 1998.

GIL, A. C. Métodos e técnicas de pesquisa social / Antonio Carlos Gil. 6 ed. São Paulo: Atlas, 2008.

GOFFMAN, E. Estigma: notas sobre a manipulação da identidade deteriorada. Rio de Janeiro: LTC, 1988.

GOLDENBERG, M. A Arte de Pesquisar: como fazer pesquisa qualitativa em Ciências Socais. Rio de Janeiro: Editora Record, 2004.

GOLDSMITH, Edward et al. A blueprint for survival. The Ecologist. Vol. 2, N. 1, 1972. Disponível em:. Acesso em 01/09/2011.

GOnÇAlveS, M. A. O Trabalho no lixo. Presidente Prudente - SP. Tese (Doutorado. Em Geografia). Programa de pós-graduação em geografia. Universidade Estadual Paulista, 2006.

GONÇALVES, P. A reciclagem integradora dos aspectos ambientais, sociais e econômicos. Rio de Janeiro: DP\&A, 2003.

GONÇALVES, R. S. Catadores de Materiais Recicláveis: trajetórias de vida, trabalho e saúde. Dissertação de Mestrado. FIOCRUZ/ENSP, 2004.

GOUVEIA, N. Resíduos sólidos urbanos: impactos socioambientais e perspectiva de manejo sustentável com inclusão social. Ciência \& saúde coletiva, Rio de Janeiro, v. 17, n. 6, pp. 1503-1510, jun, 2012.

GUIMARÃES, R. P. Políticas de meio ambiente para o desenvolvimento Sustentável: desafios institucionais e setoriais. Brasília: Planejamento e políticas públicas, 1992.

HERCULANO, S. C. Riscos e desigualdade social: a temática da Justiça Ambiental e sua construção no Brasil, In: Encontro Nacional da ANPPAS, 1, Indaiatuba, São Paulo. 2002. 
"Do desenvolvimento (in) sustentável à sociedade feliz", In Ecologia, ciência e política. Rio de Janeiro: Editora Revan, 1992.

HOBSBAWN. E. Era dos Extremos: O breve século XX 1914 - 1991. São Paulo: Companhia das Letras, 1995.

IBAM. Manual de Gerenciamento Integrado de resíduos sólidos/José Henrique Penido Monteiro.; et al. Rio de Janeiro: IBAM, 2001.

IBGE. INSTITUTO BRASILEIRO DE GEOGRAFIA E ESTATÍSTICA. Pesquisa Nacional de Saneamento Básico, 2008. Rio de Janeiro: IBGE, 2010.

IPEA. INSTITUTO DE PESQUISA ECONÔMICA APLICADA. Catadores de Materiais Recicláveis: um encontro nacional. Bruna Cristina Jaquetto Pereira, Fernanda Lira Goes (organizadoras). Rio de Janeiro: IPEA, 2016.

. Boas Práticas de Gestão de Resíduos Sólidos Urbanos e de Logística Reversa com a Inclusão de Catadoras e de Catadores de Materiais Recicláveis. Relatório de Pesquisa. Brasília: IPEA, 2015.

Situação Social das Catadoras e dos Catadores de Material Reciclável e Reutilizável - Brasil. Brasília: IPEA, 2013.

Diagnóstico dos Resíduos Sólidos de Logística Reversa Obrigatória. Relatório de Pesquisa. Brasília: IPEA, 2012.

. Pesquisa sobre Pagamento por Serviços Ambientais Urbanos (PSAU) para gestão de resíduos sólidos. Relatório de Pesquisa. Brasília: IPEA, 2010.

JACOBI, P.; BESEN, G. R. Gestão de Resíduos Sólidos em São Paulo: desafios da sustentabilidade. Estudos Avançados, USP, v. 25, p. 135-158, 2011.

Apresentação. In: JACOBI, P. (Org). Gestão compartilhada dos resíduos sólidos no Brasil: inovação com inclusão social. São Paulo, SP: Annablume, 2006.

; TEIXEIRA, M. A. Criação do Capital Social: O Caso Asmare Associação dos Catadores de Papel, Papelão e Material Reaproveitável de Belo Horizonte. Cadernos Gestão Pública e Cidadania, Vol. 2, 1997.

Meio ambiente urbano e sustentabilidade: alguns elementos para a reflexão. In: CAVALCANTI, C. (org.). Meio ambiente, desenvolvimento sustentável e políticas públicas. São Paulo: Cortez, p.384-390, 1997.

JARDIM, W. A. V.; et al. Projeto Jovens Guardiões Ecológicos: por uma nova consciência ambiental. In: III Seminário de Gestão Socioambiental para o Desenvolvimento Sustentável da Aquicultura e da Pesca, 2009, Arraial do Cabo, RJ.. Resumos do III Seminário de Gestão Socioambiental para o Desenvolvimento Sustentável da Aquicultura e da Pesca, 2009. 
JARDIM, A.; YOSHIDA, C.; MACHADO, J. V. Política nacional, gestão e gerenciamento de resíduos sólidos. Barueri, SP: Manole, 2012.

JUNCÁ, D. C. M. Mais que Sobra e Sobrantes: Trajetória de Sujeitos no Lixo. 2004. Tese de Doutorado. (Programa de Pós-graduação Saúde do Trabalhador). Fundação Oswaldo Cruz, Escola Nacional de Saúde Pública. Rio de Janeiro, 2004.

KALIL. A. P. M. C.; EFING, A. C. Política nacional de resíduos sólidos: por uma nova racionalidade no consumo. Revista Direito Ambiental e Sociedade, v. 3, p. 31-52, 2013.

LAGO, A. A. C. Estocolmo, Rio de Janeiro, Johanesburgo: O Brasil e as Três Conferências Ambientais das Nações Unidas. Brasília: Instituto Rio Branco, Fundação Alexandre de Gusmão - FUNAG, 2007.

LAYRARGUES, P. P. O Cinismo da Reciclagem: o significado ideológico da reciclagem da lata de alumínio e suas implicações para a educação ambiental. LOUREIRO, F; LAYRARGUES, P; CASTRO, R. (orgs). Educação ambiental: repensando o espaço da cidadania. São Paulo: Cortez, 2002.

O discurso empresarial verde e a ideologia da racionalidade econômica. São Paulo, Annablume, 1998.

Do ecodesenvolvimento ao desenvolvimento sustentável: evolução de um conceito? Revista Proposta, Rio de Janeiro, v. 24, n. 71, p. 1-5, 1997.

LEFF, E. "La ecologia política en América Latina: un campo en construcción", em Héctor Alimonda (compilador), Los Tormentos de la Matéria - Aportes para una Ecologia Política Latinoamericana, Buenos Aires, CLACSO, 2006.

LE PRESTRE, P. G. Ecopolítica Internacional. São Paulo: Senac-SP, $2^{\mathrm{a}}$ Ed, 2005.

LIPIETZ, A. A Ecologia Política, solução para a crise da instância política? In: Ecología política. Naturaleza, sociedad y utopia. Buenos Aires, CLACSO 2002.

LIMA, F. P. A; SOUZA, M. A. Bem público e interesses privados no tratamento do lixo urbano: o caso da parceria público-privada dos resíduos sólidos em Minas Gerais. In: Catadores de Materiais Recicláveis: um encontro nacional. Rio de Janeiro: IPEA, 2016.

LIMA, G. F. C. Alves. O gerenciamento de resíduos sólidos urbanos em Rio Pomba - MG na visão de atores sociais que participaram do processo. Tese (Doutorado em Ciências Ambientais). Universidade Federal de Goiás, Goiás, 2014.

LITTLE, P. E. Ecologia Política como Etnografia: Um Guia Teórico e Metodológico. Brasília: Peirópolis, 2006. 
LOUREIRO. C. F. B. O Movimento Ambientalista e o Pensamento Crítico: uma abordagem política. Rio de Janeiro: Quartet, 2003.

; LAYRARGUES, P. P. Ecologia Política, Justiça e Educação Ambiental Crítica: perspectivas de aliança contra-hegemônica. Trabalho, Educação e Saúde (Online), v. 11, p. 53, 2013.

LUTTNER, C. M. A.; SILVA, L. R.; FERREIRA C. D. As experiências das diferentes formas de remuneração em associações e cooperativas de catadores de materiais recicláveis dos municípios da região metropolitana de Belo Horizonte: entre desafios e possibilidades na economia solidária. In: Catadores de Materiais Recicláveis: um encontro nacional. Rio de Janeiro: IPEA, 2016.

MACHADO, G. C. A. Da Ilha de Sapucaia ao Aterro Metropolitano de Jardim Gramacho: a criação de territórios do lixo da cidade do Rio de Janeiro como expressão de segregação espacial. (Mestrado em Geografia) Programa de Pós-Graduação em Geografia da PUC-Rio, Pontifícia Universidade Católica (PUC-Rio): Rio de Janeiro - RJ, 2013.

MANSANO, J.; OLIVEIRA, A. C. Inclusão social e a política nacional de resíduos sólidos. Revista de Direito Público, Paraná, v. 7, n. 2, p.17-40, maio/ago. 2012.

MARTINEZ-ALIER, J. O Ecologismo dos pobres: conflitos ambientais e linguagens de valoração. São Paulo: Ed. Contexto. 2007.

MARTINS, G. A. Estudo de caso: uma estratégia de pesquisa. 2 ed. São Paulo: Atlas, 2008.

MARTINS, J. S. A sociedade vista do abismo: novos estudos sobre exclusão, pobreza e classes sociais. Petrópolis: Editora Vozes, 2012.

Exclusão Social e a Nova Desigualdade, $3^{\text {a }}$ ed., Editora Paulus, 2007.

MCCORMICK, J. Rumo ao paraíso: a história do movimento ambientalista. Rio de Janeiro: Relume Dumará, 1992.

MEADOWS, D. et al. Os limites do crescimento. São Paulo: Perspectiva, 1972.

MESQUITA JR, J. M. Análise crítica dos programas e dos modelos de gerenciamento de resíduos sólidos urbanos empregados no estado do Rio de Janeiro e indicação da aplicabilidade do modelo de gestão integrada para os Municípios do Estado. (Mestrado em Engenharia Ambiental) - Programa de Pós-Graduação em Engenharia Ambiental da Universidade Federal do Rio de Janeiro, (UFRJ): Rio de Janeiro - RJ, 2004.

MINAYO, M. C. S. O Desafio do Conhecimento: pesquisa qualitativa em saúde. São Paulo - Rio de Janeiro: HUCITEC-ABRASCO, 1992.

Pesquisa social: teoria, método e criatividade. Petrópolis: Vozes, 1994. 
MINISTÉRIO PÚBLICO DO RIO DE JANEIRO. Ação Civil Pública n 0000412-67.2007.8.19.0005: Rio de Janeiro, 2007.

MONTIBELLER-FILHO, G. Ecodesenvolvimento e desenvolvimento sustentável: conceitos e princípios. Florianópolis. Textos de Economia, v.4, n.1, p.131-142; 1993.

MOTA, M. J. P.; GODINHO, R. S. Desafios da Convenção sobre a Diversidade Biológica. Revista de Direito Ambiental, v. 72, p. 211-238, 2013.

MOTTA, A. C. S. Cresce a Rede de Esgotos Sanitários da Guanabara. In: Revista de Engenharia do Estado da Guanabara, Órgão da Secretaria de Obras Públicas, n. 1, Estado da Guanabara: jan./mar. 1965.

NETO, O. C. O trabalho de campo como descoberta e criação. In: Pesquisa social: teoria, método e criatividade. Petrópolis: Vozes, 1994.

OLIVEIRA, L. D. A Geopolítica do Desenvolvimento Sustentável: um estudo sobre a Conferência do Rio de Janeiro (Rio-92). Tese (Doutorado em Geografia) - Instituto de Geociências, Universidade Estadual de Campinas (UNICAMP), Campinas - SP, 2011.

PEREIRA, M. C. G. Luta por reconhecimento e desigualdade social: uma análise da experiência dos catadores da Asmare em Belo Horizonte (MG). Dissertação de Mestrado, São Paulo, 2011.

PORTO, M. F. S. et al. Lixo, trabalho e saúde: um estudo de caso com catadores em um aterro metropolitano no Rio de Janeiro, Brasil. Cadernos de Saúde Pública, v. 20, n. 6, 2004. Disponível em: <http://dx.doi.org/10.1590/ S0102311X2004000600007>.

QUEIROZ, H. A.; MARAFON, G. J. Os caminhos do lixo na Cidade do Rio de Janeiro. Cadernos do Desenvolvimento Fluminense, Rio de Janeiro, p. 037 054, 01 jul. 2015.

REVISTA MUNICÍPIOS EM DESTAQUE. Arraial do Cabo. Ano VIII, no 32, Norte e Sul Empreendimentos Editoriais Ltda. Rio de Janeiro, maio de 1988.

Arraial do Cabo. Ano XI, no 41, Norte e Sul Empreendimentos Editoriais Ltda. Rio de Janeiro, maio de 1991.

Arraial do Cabo. Ano XII, $\mathrm{n}^{\circ}$ 46, Norte e Sul Empreendimentos Editoriais Ltda. Rio de Janeiro, maio de 1992.

Arraial do Cabo. Ano XIII, $\mathrm{n}^{\circ}$ 49, Norte e Sul Empreendimentos Editoriais Ltda. Rio de Janeiro, maio de 1993.

RIO DE JANEIRO. TCE/RJ. Estudo Socioeconômico dos Municípios do Estado do Rio de Janeiro. Arraial do Cabo. Rio de Janeiro: TCE, 2017. 
TCE/RJ. Auditoria Governamental na Prefeitura de Arraial do Cabo, no âmbito do tema Resíduos Sólidos. Rio de Janeiro: TCE, 2013.

Lei $\mathrm{n}^{\circ}$ 4191, de 30 de setembro de 2003. Dispõe sobre a Política Estadual de Resíduos Sólidos e dá outras providências, Brasília, 2003.

Fundação Estadual de Engenharia do Ambiente - FEEMA. Perfil Ambiental do Município de Arraial do Cabo. Rio de Janeiro: FEEMA, 1988.

RIBEIRO, G. L. Ambientalismo e desenvolvimento sustentado: ideologia e utopia no final do século XX. Ciência da Informação, v. 21, n.1, p. 23-31, 1992.

RICHARDSON, R. J. Pesquisa Social: métodos e técnicas. 3. ed. São Paulo: Atlas, 2009.

ROCHA, R. A. M. O direito achado no "lixo": a construção do direito pela organização do Movimento Nacional de Catadores de Materiais Recicláveis. Trabalho de conclusão de curso - Universidade de Brasília. Brasília, 2013.

SACHS, I. Caminhos para o desenvolvimento sustentável. Rio de Janeiro: Garamond, (2000).

1986.

Espaços, tempos e estratégias de desenvolvimento. São Paulo: Vértice,

SANT'ANA, D.; MATELLO, D. Reciclagem e inclusão social no Brasil: balanço e desafios. In: Catadores de Materiais Recicláveis: um encontro nacional. Rio de Janeiro: IPEA, 2016.

SANTOS, H. S.; JARDIM, W. A. V.; SILVA, M. A. Implantação do programa de Coleta Seletiva no município de Arraial do Cabo - RJ.. In: Congreso Latinoamericano sobre Conflictos Ambientales, 2014, Buenos Aires. Anais do I Congreso Latinoamericano sobre Conflictos Ambientales, 2014.

; et al. Gerenciamento de Resíduos Sólidos em Arraial do Cabo - RJ.. In: Congreso Latinoamericano de Ecologia Urbana, 2012, Buenos Aires. Anais do I Congreso Latinoamericano de Ecologia Urbana, 2012. v. 1. p. 25-25.

SANTOS, J. V. A gestão dos resíduos sólidos urbanos: um desafio. Tese (Doutorado em Direito). Faculdade de Direito, Universidade de São Paulo, São Paulo: 2009.

SANTOS, M. Território e Sociedade: Entrevista com Milton Santos. 2. ed. São Paulo: Editora Fundação Perseu Abramo, 2000.

SILVA, M. G. E. Questão Ambiental e Desenvolvimento Sustentável: um desafio ético-político ao Serviço Social. São Paulo: Cortez, 2010. 
SNIS - Sistema Nacional de Informações sobre Saneamento: Diagnóstico do Manejo de Resíduos Sólidos Urbanos - 2016. Brasília: MCIDADES. SNSA, 2018.

TCU. TRIBUNAL DE CONTAS DA UNIÃO. Relatório de Levantamento. Política Nacional de Resíduos Sólidos - Análise da forma da institucionalização e normatização da PNRS. Tribunal de Contas da União, 2016.

http://portal.tcu.gov.br/lumis/portal/file/fileDownload.jsp?fileId=8A8182A2578C 7A7601579A2D6D0C1BF8. Acesso em: 3 abr. 2017.

THIOLLENT, M. (Org.). Pesquisa-ação e projeto cooperativo na perspectiva de Henri Desroche. São Carlos: EdUFSCar, 2006.

TRIVIÑOS, A. N. S. Introdução à pesquisa em ciências sociais: a pesquisa qualitativa em educação. São Paulo: Atlas, 1987.

VELlOSO, M. P. Criatividade e Resíduos Resultantes da Atividade Humana: da produção do lixo à nomeação do resto. Tese de Doutorado Saúde Pública, Escola Nacional de Saúde Pública/Fiocruz - RJ, 2004.

VIOLA, E. J.; REIS, H. J. Desordem Global da Biosfera e a Nova Ordem Internacional: O Papel Organizador do Ecologismo. In: Hector Leis (org). Ecologia e Política Mundial, 1991.

WIRTH, I. G.; OLIVEIRA, C. B. A Política Nacional de Resíduos Sólidos e os modelos de gestão. In: Catadores de Materiais Recicláveis: um encontro nacional. Rio de Janeiro: IPEA, 2016.

YIN, R. K. Estudo de caso: planejamento e métodos. Porto Alegre: Bookman, 2001. 


\section{Apêndices}

\section{Apêndice 1: Termo de Consentimento Livre e Esclarecido.}

O presente termo em atendimento à Resolução CNS 196/96, destina-se a esclarecer ao participante da pesquisa intitulada: “A Política Nacional de Resíduos Sólidos, seus avanços e retrocessos: uma análise a partir de sua implantação no município do Arraial do Cabo". A pesquisa se dará sob a responsabilidade do pesquisador Wanderson Antonio Vicente Jardim, doutorando do curso de Pós Graduação do Departamento de Serviço Social da PUC-Rio, ressalvando os seguintes aspectos:

Objetivo: Investigar se a Política Nacional de Resíduos Sólidos contribuiu para a inclusão social dos catadores e das catadoras de materiais recicláveis no processo de gestão ou se esse ordenamento jurídico que regula essa atividade econômica colabora no sentido incluí-los precariamente, minimizando os conflitos socioambientais e reforçando os mecanismos de vulnerabilidade e injustiça social.

Justificativa: Pretendemos demonstrar que embora haja um arcabouço legal para efetiva participação dos catadores e catadoras de materiais recicláveis no processo de gestão compartilhada dos resíduos, na prática o que ocorre é que o segmento sucumbe a uma lógica excludente que colabora com os mecanismos de injustiças ambientais, reforçando os laços de dependência deste segmento social junto à administração pública. Pretendemos também contribuir para mostrar as fragilidades e limitações da Política Nacional de Resíduos, bem como os seus reflexos nas condições organizativas, econômicas, sociais e laborais dos catadores e das catadoras de materiais recicláveis, que apesar de serem essenciais à expansão da indústria de reciclagem e realizarem um serviço de extrema utilidade pública para a sociedade, com benefícios múltiplos, são estigmatizados, desprotegidos, alheios à rentabilidade da atividade produtiva e espoliados ao ponto de não serem incluídos efetivamente na gestão compartilhada de resíduos, mesmo tendo uma legislação federal nesta direção. 
Confidencialidade do estudo: Garantia de esclarecimento: os voluntários participantes terão todas e quaisquer formas de esclarecimento e informações sobre a pesquisa, bem como da metodologia adotada a todo e qualquer momento.

Participação Voluntária: A participação dos sujeitos da pesquisa no projeto é voluntária e livre de qualquer forma de remuneração. Os questionários serão de uso exclusivo do entrevistador, e assim sendo, não será anexado à tese. Cabe ressaltar, no entanto, que os dados serão analisados no corpo da tese, respeitandose a veracidade do conteúdo e à confidencialidade.

Consentimento para participação: estou de acordo com os termos para a participação no estudo descrito acima. Fui devidamente esclarecido (a) quanto aos objetivos da pesquisa e aos procedimentos. Os pesquisadores me garantiram disponibilizar qualquer esclarecimento adicional a que eu venha solicitar durante o curso da pesquisa e o direito de desistir da participação até um mês antes da data da entrega da tese, sem que a minha desistência implique em qualquer prejuízo à minha pessoa, sendo garantido anonimato e o sigilo dos dados referentes à minha identificação, bem como de que a minha participação, neste estudo, não me trará nenhum benefício econômico.

$\mathrm{Eu}$,

aceito livremente participar do estudo intitulado "A Política Nacional de Resíduos Sólidos, seus avanços e retrocessos: uma análise a partir de sua implantação no município do Arraial do Cabo", desenvolvido pelo pesquisador para o trabalho de Tese de Doutorado.

Doutorando: Wanderson Antonio Vicente Jardim

Orientadora: Professora Doutora Valéria Pereira Bastos

Contato do Departamento de Serviço Social da PUC-Rio: (21) 3527-1290 


\section{Apêndice 2: Roteiro de entrevista com os catadores da Cooperativa de Coleta e Reciclagem da Costa do Sol.}

\begin{tabular}{|c|}
\hline DADOS GERAIS \\
\hline Data da entrevista: \\
\hline Nome: \\
\hline Data de Nascimento: \\
\hline Local: \\
\hline Filiação: \\
\hline Estado civil: \\
\hline Escolaridade: \\
\hline Portador de necessidade especial: \\
\hline RG: \\
\hline CPF: \\
\hline Têm filhos: \\
\hline Quantos: \\
\hline DADOS ECONÔMICOS \\
\hline Renda mensal atual: \\
\hline Recebe benefícios sociais: \\
\hline Renda mensal antes de ser cooperativado: \\
\hline Possui outra fonte de renda: $\quad$ Quanto: \\
\hline Quantas pessoas vivem da sua renda? \\
\hline Outras pessoas contribuem com a renda da casa? \\
\hline DADOS DE MORADIA \\
\hline Endereço: \\
\hline Bairro: \\
\hline Tipo de moradia? \\
\hline Reside há quanto tempo? \\
\hline Possui água encanada? \\
\hline Rede elétrica? \\
\hline Rede de esgoto? \\
\hline Coleta regular de lixo? \\
\hline DADOS PROFISSIONAIS \\
\hline Há quanto tempo trabalha como catador de materiais recicláveis? \\
\hline Há quanto tempo faz parte da cooperativa? \\
\hline Como entrou na cooperativa? \\
\hline Qual a sua função na Cooperativa? \\
\hline Possui alguma qualificação profissional? \\
\hline Já exerceu outra profissão? \\
\hline
\end{tabular}




\begin{tabular}{|l|}
\hline \multicolumn{1}{|c|}{ CONDIÇÕES DE TRABALHO E SALUBRIDADE } \\
\hline Já sofreu algum acidente trabalhando na cooperativa? \\
\hline Possui alguma doença ocupacional? \\
\hline Você utiliza Equipamentos de Proteção Individual - EPI? \\
\hline Há fiscalização pelos órgãos público sobre uso de EPI? \\
\hline Possui históico de vacinação? \\
\hline Existe campanha de vacinação municipal? \\
\hline Quais melhorias você gostaria que fossem realizadas no seu trabalho? \\
\hline
\end{tabular}


Apêndice 3: Roteiro de entrevista com os catadores da Cooperativa de Coleta e Reciclagem da Costa do Sol.

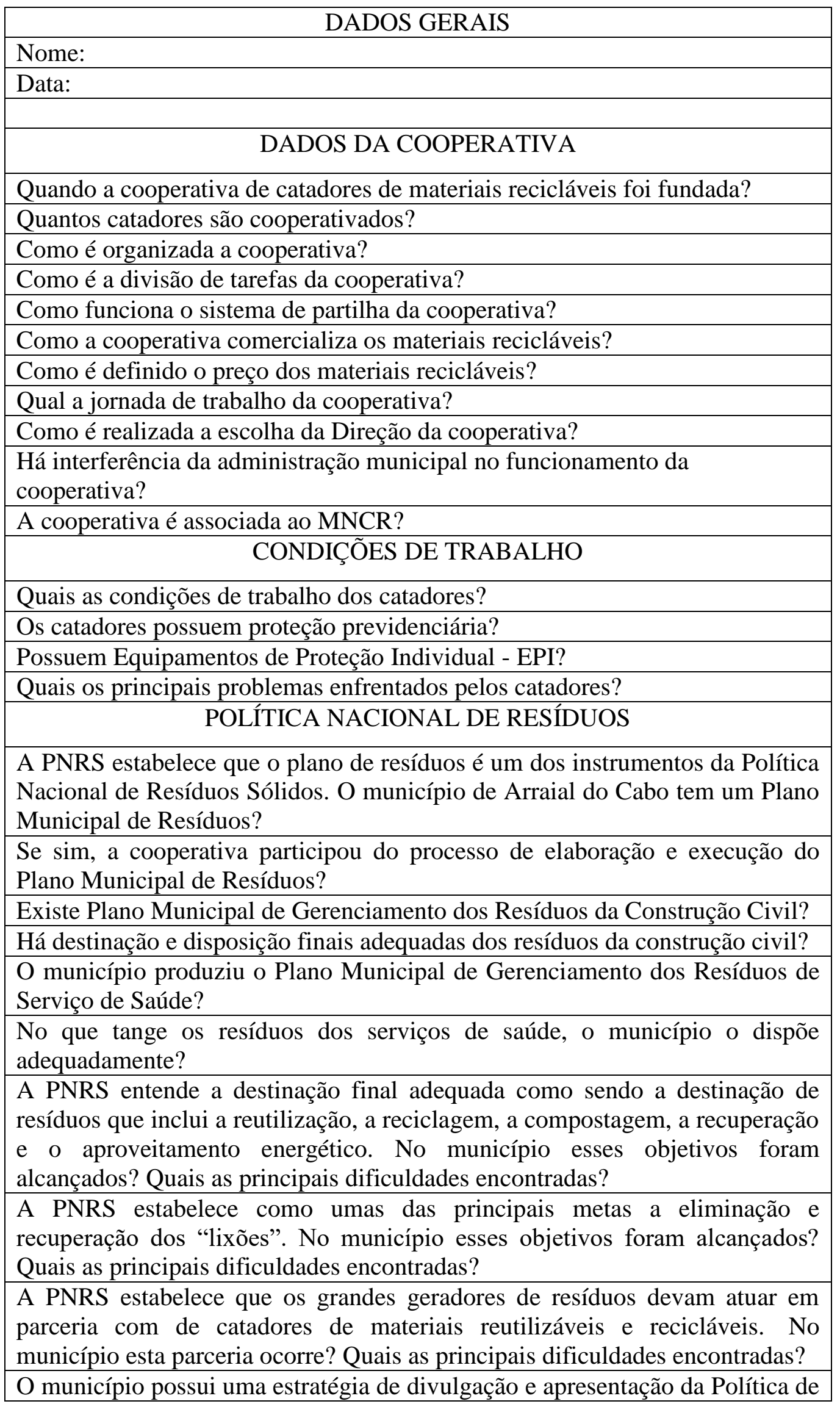


Resíduos Sólidos?

A PNRS estabelece como prioritária a inclusão social e a emancipação econômica de catadores de materiais reutilizáveis e recicláveis? No município esse objetivo foi alcançado? Quais as principais dificuldades encontradas?

Existe o apoio técnico, orçamentário e financeiro para a coleta seletiva voltada à inclusão social e a emancipação econômica dos catadores e das catadoras de materiais recicláveis?

Os catadores são responsáveis por um percentual de $90 \%$ dos materiais recicláveis, todavia recebem apenas $10 \%$ do lucro deste processo. Qual a sua opinião sobre essa realidade?

Você se sente excluído (a) ou incluído (a) na gestão de resíduos do município? Você se sente vulnerável neste trabalho?

No dia 2 de agosto foi sancionada a Lei $\mathrm{n}^{\circ}$ 12.305/10, que estabeleceu a Política Nacional de Resíduos Sólidos (PNRS). Quais os resultados práticos dessa lei para o município de Arraial do Cabo? 


\section{Apêndice 4: Roteiro de entrevista com os dirigentes do movimento dos catadores de materiais recicláveis.}

\begin{tabular}{|c|}
\hline DADOS GERAIS \\
\hline Nome: \\
\hline Instituição: \\
\hline Data: \\
\hline POLÍTICA NACIONAL DE RESÍDUOS \\
\hline Fale um pouco sobre a sua história. \\
\hline Como entrou no movimento de catadores de materiais recicláveis? \\
\hline Como é a sua atuação no movimento dos catadores de materiais recicláveis? \\
\hline $\begin{array}{l}\text { A PNRS estabelece que o plano de resíduos é um dos instrumentos da Política } \\
\text { Nacional de Resíduos Sólidos. O que acha do Plano Nacional de Resíduos } \\
\text { Sólidos não ter sido publicado ainda? }\end{array}$ \\
\hline $\begin{array}{l}\text { A PNRS entende a destinação final adequada como sendo a destinação de } \\
\text { resíduos que inclui a reutilização, a reciclagem, a compostagem, a recuperação } \\
\text { e o aproveitamento energético. Você considera que esses objetivos foram } \\
\text { alcançados no Brasil? Quais as principais dificuldades encontradas? }\end{array}$ \\
\hline $\begin{array}{l}\text { A PNRS estabelece como umas das principais metas a eliminação e } \\
\text { recuperação dos "lixões". Você considera que esses objetivos foram } \\
\text { alcançados no Brasil? Quais as principais dificuldades encontradas? }\end{array}$ \\
\hline $\begin{array}{l}\text { A PNRS estabelece que os grandes geradores de resíduos devam atuar em } \\
\text { parceria com de catadores de materiais reutilizáveis e recicláveis. Você } \\
\text { considera que esses objetivos foram alcançados no Brasil? Quais as principais } \\
\text { dificuldades encontradas? }\end{array}$ \\
\hline $\begin{array}{l}\text { Qual a sua avaliação sobre a estratégia de divulgação e apresentação da } \\
\text { Política de Resíduos Sólidos? }\end{array}$ \\
\hline $\begin{array}{l}\text { A PNRS estabelece como prioritária a inclusão social e a emancipação } \\
\text { econômica de catadores de materiais reutilizáveis e recicláveis? Você } \\
\text { considera que esses objetivos foram alcançados no Brasil? Quais as principais } \\
\text { dificuldades encontradas? }\end{array}$ \\
\hline $\begin{array}{l}\text { Existe o apoio técnico, orçamentário e financeiro para a coleta seletiva voltada } \\
\text { à inclusão social e a emancipação econômica dos catadores e das catadoras de } \\
\text { materiais recicláveis? }\end{array}$ \\
\hline $\begin{array}{l}\text { Os catadores são responsáveis por um percentual de } 90 \% \text { dos materiais } \\
\text { recicláveis, todavia recebem apenas } 10 \% \text { do lucro deste processo. Qual a sua } \\
\text { opinião sobre essa realidade? }\end{array}$ \\
\hline $\begin{array}{l}\text { No dia } 2 \text { de agosto foi sancionada a Lei } \mathrm{n}^{\circ} 12.305 / 10 \text {, que estabeleceu a } \\
\text { Política Nacional de Resíduos Sólidos (PNRS). Quais os resultados práticos } \\
\text { dessa lei? }\end{array}$ \\
\hline
\end{tabular}


Apêndice 5: Roteiro de entrevista com os gestores públicos.

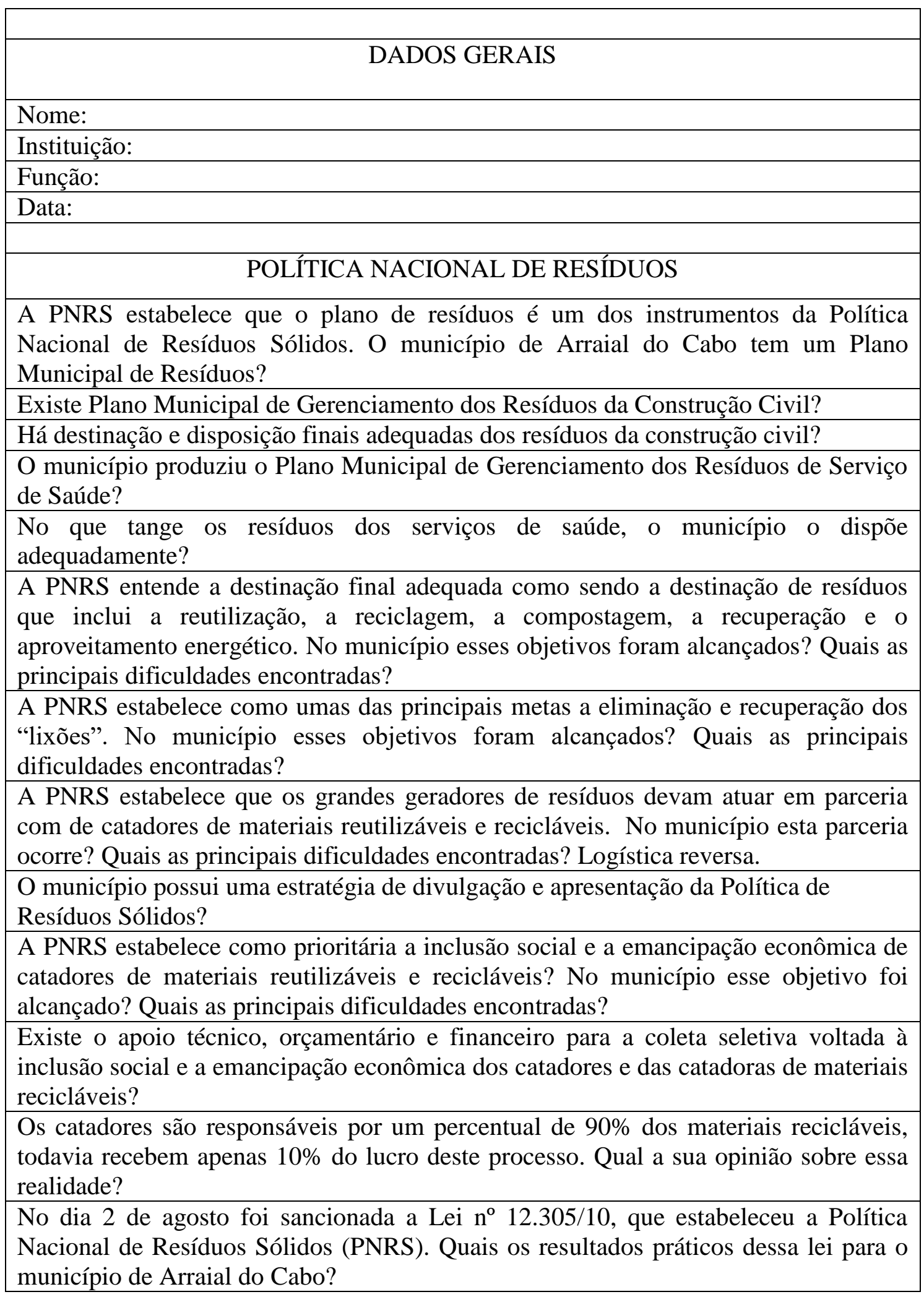

